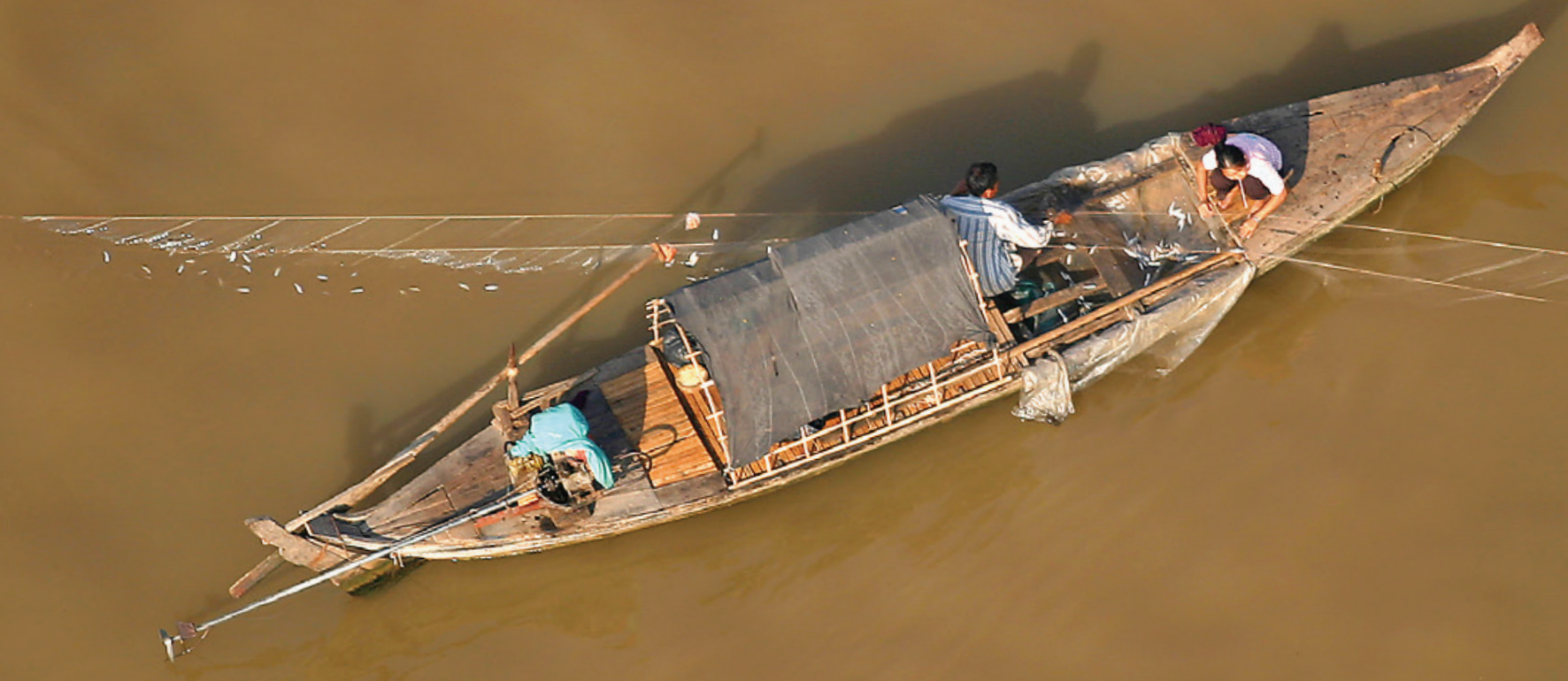

Status and Trends of Fish Abundance and Diversity in the Lower Mekong Basin during 2007-2018

MRC Technical Paper No. 66 
The MRC is funded by contributions from its Member Countries and Development Partners, including Australia, the European Union, Finland, Flanders/Belgium, France, Germany, Japan, Luxembourg, the Netherlands, New Zealand, Sweden, Switzerland, the United States of America and the World Bank. 


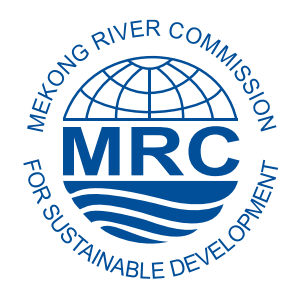

\title{
STATUS AND TRENDS OF FISH ABUNDANCE AND DIVERSITY IN THE LOWER MEKONG BASIN DURING 2007-2018
}

\author{
MRC Technical Paper
}


Copyright (C) Mekong River Commission 2021

First published (2021)

Some rights reserved

This work is a product of the Mekong River Commission Secretariat with external contributions. The findings, interpretations and conclusions expressed in this work are those of the authors and do not necessarily reflect the views of the Mekong River Commission, nor its member countries or the governments they represent. While all efforts are made to present accurate information, the Mekong River Commission Secretariat does not guarantee the accuracy of the data included in this work. The boundaries, colours, denominations, and other information shown on any map in this work do not imply any judgement on the part of the Mekong River Commission Secretariat concerning the legal status of any territory or the endorsement or acceptance of such boundaries.

Nothing herein shall constitute or be considered to be a limitation upon or waiver of the privileges and immunities of the Mekong River Commission, all of which are specifically reserved.

This publication may be reproduced in whole or in part and in any form for educational or non-profit purposes without special permission from the copyright holder, provided acknowledgement of the source is made and notification is sent to the MRC. The Mekong River Commission would appreciate receiving a copy of any publication that uses this publication as a source. This publication cannot be used for sale or for any other commercial purpose whatsoever without permission in writing from the Mekong River Commission.

Title: Status and trends of fish abundance and diversity in the Lower Mekong Basin during 2007-2018 (MRC Technical Paper No. 66)

ISSN: 1683-1489

Keywords: Fisheries/Lower Mekong Basin / catch per unit effort / abundance-biomass curves /beta diversity

For bibliographic purposes, this volume may be cited as:

Mekong River Commission. (2021). Status and trends of fish abundance and diversity in the Lower Mekong Basin during 2007-2018 (MRC Technical Paper No. 66). Vientiane: MRC Secretariat. https://doi. org/10.52107/mrc.qx5yo0

Information on MRC publications and digital products can be found at http://www.mrcmekong.org/publications/.

Graphic designer: Anouvong Manivong

All queries on rights and licenses should be addressed to:

Mekong River Commission

Documentation and Learning Centre

184 Fa Ngoum Road, Unit 18, Ban Sithane Neua, Sikhottabong District, Vientiane 01000, Lao PDR

Telephone: +856-21263263 | E-mail: mrcs@mrcmekong.org | www.mrcmekong.org 


\section{CITATION}

Mekong River Commission. (2021). Status and trends of fish abundance and diversity in the Lower Mekong Basin during 2007-2018 (MRC Technical Paper No. 66). Vientiane: MRC Secretariat. https://doi.org/10.52107/mrc.qx5yo0.

\section{AUTHORS}

\section{Management}

Mr Socheat Hak, Director of the Environmental Management Division, MRC Secretariat; Dr Nam So, Chief Environment Management Officer, MRC Secretariat

Regional technical expert

Mr Vanna Nuon, Fisheries and Aquatic Ecology Officer, MRC Secretariat

National technical experts

\section{Cambodia}

Mr Solyda Putrea, Head of the Biology Office, Inland Fisheries Research and Development Institute (IFReDI); Mr Sokheng Chan, Vice Head, Technology Research Office, IFReDI; Mr Sovannara Heng, Director, Department of Exploitation Control and Conservation, Tonle Sap Authority (TSA); and Mr Touch Ou, Vice Chief, Exploitation Control Office, TSA

\section{Lao PDR}

Dr Kaviphone Phouthavong, Deputy Director General, Department of Livestock and Fisheries; and Mr Saleumphone Chanthavong, Deputy Chief, Capture Fisheries Unit, Living Aquatic Resources Research Centre

\section{Thailand}

Dr Deeka Ratanachamnong, Fishery Biologist, Inland Fisheries Research and Development Division (IFReDD), Department of Fisheries; and Mr Kosol Sriputinibondh, Fishery Biologist, IFReDD

\section{Viet Nam}

Dr Phan Thanh Lam, Acting Director, Research Institute for Aquaculture (RIA) No. 2; Mr Nguyen Du, Vice head, Aquatic Resources, RIA No. 2

International technical expert

Dr Sovan Lek, Professor, Université de Toulouse III Paul Sabatier, Toulouse, France 


\section{CONTENTS}

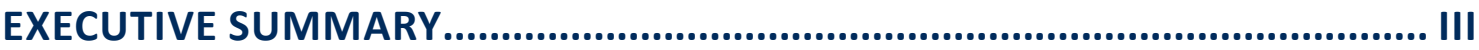

INTRODUCTION

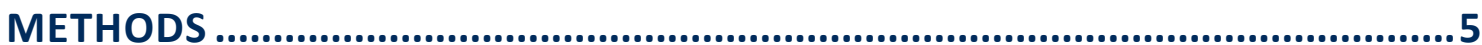

2.1 Monitoring Stations

2.2 Fisher Selection

2.3 Sampling Techniques

2.4 Data Collection

2.5 Data Analysis

RESULTS

3.1 Contribution of fish species and guilds to the fisheries of the LMB

3.2 Status and Trends of Fish Catch in the LMB

3.3 Spatial and Temporal Patterns of Fish Abundance and Diversity in the LMB

3.4 Fish Community Patterns and their Relationship with Environmental Factors

DISCUSSIONS

4.1 Fish Diversity in the LMB

4.2 Status of Fish Catches in the LMB

4.3 Fish Assemblage and the Influence of Environmental Factors

CONCLUSIONS 63

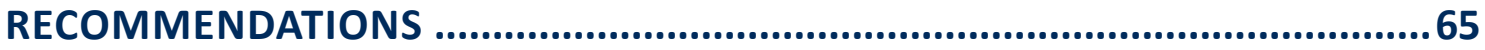

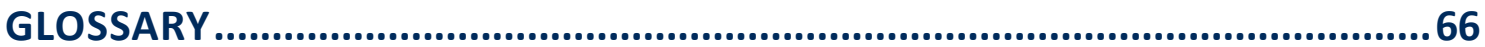

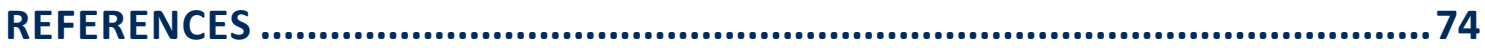




\section{FIGURES}

Figure 1.1 Number of fish species of each of the eleven guilds in the Lower

Mekong Basin

Figure 2.2 Map of the Lower Mekong Basin showing FADM monitoring stations and hydropower dams

Figure 2.3 Sampling activity at each of the 25 stations across the survey period from 2007 to 2018 (big black circles).

Figure 3.1 Relative abundance and biomass per fish order in the LMB .......................... 16

Figure 3.2 Relative abundance and biomass per fish family in the LMB ........................... 17

Figure 3.3 Relative abundance and biomass of fish in the LMB in relation to ecological functional characteristics

Figure 3.4 Rank species relative abundance distributions of FADM stations in log-log scale

Figure 3.5 Site-rank relative abundance in the LMB; (a) the decreasing order of fish abundance by station; (b) the decreasing order of the abundance of fish species

Figure 3.6 Rank-abundance distribution curve in each BioRA zone: a) Zone 2;

b) Zone 3; c) Zone 3S; d) Zone 4; e) Zone 7; f) Zone 8

Figure 3.7 Scatterplot of relative biomass as a function of relative abundance of fish in the LMB during the FADM period, fitted by Loess smoothing

Figure 3.8 Scatterplot between yearly species abundance and species biomass from all FADM monitoring stations 24

Figure 3.9 The relative Abundance-Biomass Curve $(A B C)$ of the LMB ........................... 25

Figure 3.10 Spatial variation of the $A B C$ curve in each BioRA zone of the LMB ................. 26

Figure 3.11 Catch per unit effort (CPUE) in $\log _{10}$ scale of gillnets for each station under BioRA zones, a: Zone2, b: Zone3, c: Zone4, d: Zone3S, e: Zone7 and f: Zone8 
Figure 3.12 Mean catch per unit effort for each BioRa zone ........................................... 30

Figure 3.13 Cumulative annual fish species caught at each monitoring station, sorted for each BioRA zone

Figure 3.14 Annual species accumulation curves of the 25 FADM stations

Figure 3.15 Violin plot and boxplot showing the distribution of Species Richness

(SR) for different BioRA zones in the LMB

Figure 3.16 Violin plot and boxplot of fish abundance (log) for different BioRA zones of the LMB

Figure 3.17 Scatterplot of the relationship between species richness and fish abundance (log) pooled by BioRA zones

Figure 3.18 Scatterplot of monthly species richness from 2007 to 2018, fitted by linear models for each BioRA zone

Figure 3.19 Scatterplot of monthly fish abundance (in log transform) from 2007 to 2018 , fitted by linear models for each BioRA zone

Figure 3.20 Diversity indices of fish in each BioRA zone: The inverse Simpson Index (D), the Shannon-Wiener Index (sh) and the Evenness Index (E)

Figure 3.21 Diversity indices of fish in the LMB from 2007 to 2018: The inverse Simpson index (D), the Shannon-Wiener index (sh) and the Evenness index (E) .....

Figure 3.22 Distribution of LCBD in the FADM stations ............................................... 41

Figure 3.23 Species Contribution to Beta Diversity (SCBD) in the LMB ............................ 42

Figure 3.24 Dendrogram of hierarchical clustering of yearly site fish species in the LMB showing the 4 clusters of samples according to the degree of dissimilarity

Figure 3.25 PCA on fish community results showing samples by zones (different colours) . 51

Figure 3.26 Relationship between water level and fish richness, diversity and abundance fitted by Loess curves

Figure 3.27 Relationship between water temperature and fish richness, abundance and diversity indices fitted by Loess curves 53

Figure 3.28 Relationship between dissolved oxygen and fish richness, abundance and diversity indices fitted by Loess curves 54 
Figure 3.29 Relationship between $\mathrm{pH}$ and fish richness, abundance and diversity indices fitted by Loess curves

Figure 3.30 Triplot of the Redundancy Analysis (RDA) showing the correspondence between environmental factors and fish, and their related samples in the LMB. The ellipsoids represent the $1 \mathrm{SD}$ of sample distribution of the LMB BioRA zones 


\section{TABLES}

Table 2.1 Monitoring stations inside each BioRA zone ................................................... 6

Table 3.1 Results of pair-wise comparison using the Mann-Whitney test showing the probability of pairs of richness between BioRA zones in the LMB. The $p$-values lower than 0.05 mean significant differences between the pairs of zones

Table 3.2 Results of pair-wise comparison using the Mann-Whitney test showing the probability of pairs of fish abundance difference between BioRA zones in the LMB. The $\mathrm{p}$-values lower than 0.05 mean significant differences between the pair of zones

Table 3.3 Correspondence between BioRA zones of the LMB and results of hierarchical clustering based on yearly fish composition in the LMB during the FADM survey period

Table 3.4 Indicator species with indicative statistical values andassociated probability See sample membership of each group in Annex 5 


\section{ABBREVIATIONS AND ACRONYMS}

$A B$

AB.log

ABC

ANOVA

ANCOVA

BD

CA

CCA

CPUE

CV

CR

D

DD

DO

E

ED

EN

FADM

GLM

HSD

IndVal

IUCN

LC

LCBD

Abundance

Log of Abundance

Abundance-Biomass Curve

Analysis of Variance

Analysis of covariance

Beta Diversity

Correspondence Analysis

Canonical Correlation Analysis

Catch Per Unit Effort

Coefficient of Variation

Critically Endangered

Simpson Index

Data Deficient

Dissolved Oxygen

Evenness index

Environmental Management Division

Endangered

Fish Abundance and Diversity Monitoring

General Linear Model

Honest Significant Difference

Indicator Species Value

International Union for Conservation of Nature

Least Concerned

Local Contribution for Beta Diversity 


$\begin{array}{ll}\text { LMB } & \text { Lower Mekong Basin } \\ \text { LMR } & \text { Lower Mekong River } \\ \text { MCs } & \text { Member Countries } \\ \text { MLR } & \text { Multiple Linear Regression } \\ \text { MRC } & \text { Mekong River Commission } \\ \text { MRCS } & \text { Mekong River Commission Secretariat } \\ \text { NA } & \text { Not Assessed } \\ \text { NT } & \text { Near Threatened } \\ \text { PAs } & \text { Fish Protected Areas } \\ \text { PCA } & \text { Principal Components Analysis } \\ \text { PH } & \text { Potential of Hydrogen } \\ \text { RDA } & \text { Redundancy Analysis } \\ \text { RIA } & \text { Research Institute for Aquaculture } \\ \text { SCBD } & \text { Species Contribution to Beta Diversity } \\ \text { SD } & \text { Standard Deviation } \\ \text { SE } & \text { Standard Error } \\ \text { Sh } & \text { Shannon-Wiener Index } \\ \text { SR } & \text { Species Richness } \\ \text { TSA } & \text { Tonle Sap Authority } \\ \text { VU } & \text { Vulnerable } \\ \text { WL } & \text { Water Level } \\ \text { WWF } & \text { World Wildlife Fund } \\ & \end{array}$




\section{EXECUTIVE SUMMARY}

\section{Introduction}

This report describes the status and trends of fish abundance and diversity from the Mekong River Commission (MRC). The Fish Abundance and Diversity Monitoring (FADM) Programme in the Lower Mekong Basin (LMB) is a routine, artisanal fisheries monitoring programme to determine both status and trends of fish abundance and its diversity in the LMB through temporal and spatial variation. The monitoring was conducted daily between 2007 and 2018 by professional fishers at 25 stations along Mekong mainstream and major tributaries. Eleven of the 25 monitoring stations were in Cambodia, four in Lao PDR, and five each in Thailand and Viet Nam.

At the regional scale, the monitoring stations were grouped based on Biological Resource Assessment (BioRA) Zones following the MRC Council Study: Zone 2 ( 3 stations from Nam Beng to upstream of Vientiane), Zone 3 (6 stations from Vientiane to Nam Kam), Zone 4 (3 stations from Nam Kam to Kratie), Zone 7 (7 stations in the Tonle Sap Great Lake and Tonle Sap River), Zone 8 (5 stations in the Mekong Delta), and Zone 3S (3 stations in Sekong, Sesan and Sre Pok rivers).

The study aims to: (i) evaluate the contribution of fish species and guilds to the fisheries of the LMB; (ii) evaluate the status and trends in fish catch; (iii) monitor spatial and temporal patterns in fish abundance and diversity; and (iv) assess fish community patterns and their relationship with environmental factors. 


\section{Key findings}

\section{Contribution of fish species and guilds to the fisheries of the $L M B$}

Overall, from 2007 to 2018, the MRC-FADM programme in the LMB found 617 fish species belonging to 21 orders and 80 families; $37,530,460$ individuals, corresponding to $1,095,848 \mathrm{~kg}$ of fishes were collected. Cypriniformes and the Cyprinidae were the dominant order and family, respectively, with more than $45 \%$ of total abundance and biomass. Over the monitoring period, the catch was driven by small-size or short-lived fish species, such as species of mud carps, Henicorhynchus ( $H$. siamensis and H. lobatus).

With regard to the functional guilds, the generalist fishes (29\%) were dominant in the catch in terms of relative fish abundance, followed by the floodplain spawners or grey fishes (21\%) and the floodplain residents or black fishes (18\%). However, for the relative biomass, it was observed that the main-channel spawners or short-distance white fishes (26\%) were the dominant guild, followed by the generalists (23\%). Regarding the conservation status, most fish caught were under the least concern species (around $50 \%$ of total abundance or biomass). The LMB accounted for a low but increasing rate of exotic species ( $<1 \%$ of abundance, or about $1.5 \%$ of the biomass), an alarming signal.

\section{Status and trend of fish catch in the LMB}

The abundance-biomass comparison curve ( $A B C$ curve) showed that the LMB is moderately disturbed, with the value of $W=-0.03$. At the BioRA Zone level, except for Zone 3S, all zones had negative $W$ values, indicating that these zones were under stress. The highest stress was observed at Zones 2 and 4, with an ABC curve largely placed above the biomass curve. The $3 \mathrm{~S}$ rivers were the unique, least-stressed zone of $L M B$, with the positive $W$ value, and the biomass curve was over the abundance curve.

With regard to the catch rate or CPUE, in Cambodia the fish catch rate showed an upward trend at most of the FADM stations (eight out of 11 stations). In Lao PDR, the catch rate slightly dropped since the fish catch rate showed a decreasing trend at two of four stations. Unlike in Lao PDR, in Thailand, the catch rate slightly increased as four out of five stations equally showed the increasing and stable trends. In Viet Nam, the catch rate decreased, as three of five stations showed the downward trends of the catch rate.

\section{Spatial and temporal patterns of fish abundance and diversity in the LMB}

At the BioRA Zone level, Zone 4 and Zone 3S have the highest average species richness (around 115 species) compared with other zones in the LMB. Zone 7 (Tonle Sap) also has high average species richness but with a larger distribution. The upper part of Lower Mekong and the delta area have lower average richness, with only around 50 species.

Regarding the relative fish abundance, Zone 7 (Tonle Sap) was the highest, followed by the 
Mekong Delta (Zone 8). The other zones had similar and constant fish abundance over the monitoring period, except for Zone 3 , which had a relatively large range of abundance.

Temporally, Zones 4 and 8 decreased in richness over time, but in Zones 2, 3 and 7, richness increased slightly. Also, the richness of Zone $3 \mathrm{~S}$ appeared to be stable during the survey period.

The temporal trends of relative fish abundance in the LMB showed different results compared to species richness. Only Zone 7 (Tonle Sap Lake) saw an increase in relative abundance during the survey period, while Zones 2, 4 and 8 decreased in relative abundance. The remaining zones had a stable trend during the same period.

\section{Relationships between fish community and environmental factors in the LMB}

Fish communities in LMB were classified into four groups based on their similarity. Cluster 1 mostly comprised fish species at the upstream of the LMB, where most part of the river shares between Lao PDR and Thailand. Also, six indicator species, found in this cluster, belonged to three guilds, namely grey fish, black fish and estuarine resident. Cluster 2 mostly comprised the floodplain, tributary and canal fish communities at Tonle Sap Lake, the middle part of the LMB and Viet Nam Mekong Delta. This cluster was also home to 14 indicator species with five guilds, whose dominant one was the short-distance white fish. Cluster 3 mostly comprised the fish communities at the north-eastern part of Cambodia with 57 indicator species and two dominant guilds, the short-distance white fish and grey fish. The last cluster mainly comprised fish communities at the stations adjacent to the sea with 19 indicator species, divided into five guilds. Estuarine resident and marine visitor were the dominant guilds of this cluster.

In the LMB, fish diversity and richness had a significant link to temperature, dissolved oxygen (DO), and the neutral $\mathrm{pH}$ around 7. This study indicated that fish communities of Zones 4 and $3 \mathrm{~S}$ at the upper part of Cambodia was associated with a high DO and water levels, opposite to that of Zone 8 in the Viet Nam Mekong Delta. Moreover, the fish communities of Zone 7 at the Tonle Sap Lake and some parts of Zone 8 had a strong relationship with high temperatures in contrast to those of Zones 2 and 3 from Lao PDR and Thailand with lower temperature and higher pH. 


\section{Conclusion and recommendations}

- Fish abundance and diversity need to be protected to sustain food supplies for millions of people living in the LMB. This study showed that LMB fisheries are under stressed conditions due to overfishing and habitat degradation induced by human population growth and economic development, and environmental changes (e.g. flow change) including climate change. With a constant increasing of human population, fishing pressure in LMB constantly increased, affecting the fish abundance and diversity.

- A number of hydropower projects have been built and proposed in the mainstream, although fisheries monitoring stations are not located close to the project sites. This makes it difficult to develop a baseline before the hydropower projects are operational. Thus, it is critical to set up more monitoring stations close to dam sites. This will enable hydropower projects in the Mekong mainstream to be assessed in terms of their impacts. MRC's Joint Environmental Monitoring Guidelines should be consulted when selecting monitoring stations close to dam sites.

- Data have been collected by participating fishers who use multiple types of fishing gear to catch fish. Thus, it is suggested that standardized gear, for example, multiple panel gillnets, be used in the FADM programme to strengthen the results.

- The results of $A B C$ curves showed that fish communities in almost all zones were disturbed, so it is crucial that the governments of the four Member Countries effectively enforce their national fisheries laws and jointly implement the approved Mekong Basin-wide Fisheries Management and Development Strategy to restore these disturbed fish communities.

- In regard to key habitat connectivity within and between zones, importantly, integrated river management plans should consider threats resulting from hydropower development.

- Transboundary fish protected areas or transboundary fish conservation zones should be set up to maintain biodiversity in the LMB, especially during spawning, and egg and larvae development periods.

- Since the current study mainly focuses on the current climate regardless of future climate change, a study on the impact of climate change on fish abundance and diversity in the LMB should be conducted.

- A study on the impact of sand mining on fish populations and fisheries in the LMB should be carried out to assist policymakers in formulating policy to minimize the impact of sand mining. 


\section{1}

\section{INTRODUCTION}

The Mekong River is the world's 12th longest river with a length of 4,763 km, the 8th largest by flow with a mean annual discharge of approximately $446 \mathrm{~km} 3$, and the 21st largest by basin area draining 810,000 km2 (Mekong River Commission [MRC], 2018b). It flows through China, Myanmar, Lao PDR, Thailand, Cambodia and Viet Nam before discharging into the South China Sea.

The Mekong River serves as an important source of food, transportation, and livelihood for millions of people residing in its basin. It is known for its rich biodiversity and diverse ecological systems, providing home to some of the world's highest diversities of fish and snails, as well as a number of critically endangered species, such as the Irrawaddy dolphin and the giant Mekong catfish (Campbell, 2009). A recent literature review by the MRC revealed that the Mekong Basin is home to 1,148 fish species categorized into 11 guilds as shown in Figure 1.1 (MRC, 2018a). The survey results from long-term fisheries monitoring by the MRC have recorded 617 fish species in the Lower Mekong Basin (LMB). 


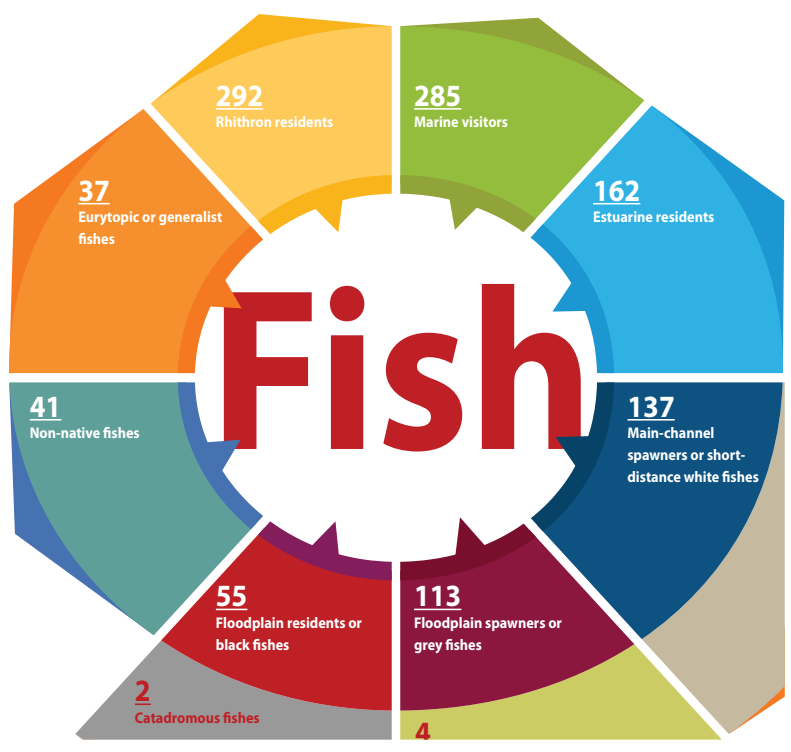

Figure 1.1 Number of fish species of each of the eleven guilds in the Lower Mekong Basin (Source: MRC, 2018a)

Due to the recent acceleration of water resources development, the Mekong Basin has undergone rapid change. Significant impacts downstream due to the development of hydropower dams in the upper part of the Mekong River in China (Lancang River) have been experienced, such as: (i) a decrease in peak flow and annual flood volumes; (ii) lower early flood season flows and higher late flood season flows; (iii) the late start and end of flood season conditions; (iv) increase in dry season flows; (v) habitat fragmentation; and (vi) changes in water quality and sedimentation. All these impacts contribute to the decline and degradation of fisheries resources and aquatic ecology. Mainstream hydropower dams also account for a $40 \%$ decline in fish biomass, whereas tributary dams have significant impacts on the health of river ecosystems. Increases in channel erosion due to dams is having serious effects on the availability of river and floodplain habitats, decreases in the productivity of floodplains, and fundamental changes to fish communities (MRC, 2017). A study by the MRC (2017) reported effects on migratory fish species from dam development as fish ladders might not be able to accommodate the intensity and diversity of fish.

Climate change is another major issue in fisheries development in the LMB as it can alter fish species composition and distribution leading to the loss of species abundance and diversity (Parmesan \& Yohe, 2003); lead to an increase in invasive species (Sutherst, 2000); shift the habitat ranges of species (Beisner et al., 1997; Thomas et al., 2004); and change hydrological patterns of the Mekong River. The increased occurrence of extreme events and changes in flow reversal of the Tonle Sap Lake are contributing to a potential adverse effects on the Mekong River and its 
tributaries in terms of ecosystem functioning and resilience, which has a major influence on fish communities (MRC, 2015). Climate change and water infrastructure development also impact on 3 mainstream flows and on the LMB's biodiversity and fisheries (Arias et al., 2012, 2014).

Fisheries resources have also been threatened in the LMB in both the Mekong River and Tonle Sap Lake due to the use of destructive fishing methods (explosives, poisons, and electrocution), and illegal fishing in spawning season and at spawning grounds (Coates et al., 2003; Nuon \& Gallado, 2011; Ngor et al., 2018; Chan et al., 2020). For example, fish migration channels in Boeung Chhmar Ramsar Site have been blocked, leading to a problem in fish recruitment (WWF, 2013). Further, Tonle Sap Lake's flooded forest is facing degradation from the expansion of fishing, harvesting of the forest for fuel wood, and conversion to agriculture land.

The Fish abundance and diversity monitoring programme was established in the 2000s (MRC, 2013). This long-term monitoring programme captures the temporal change of relative fish abundance, fish diversity and communities in the LMB, which has never been done before. Therefore, the objectives of this report are to: (i) evaluate the contribution of fish species and

guilds to the fisheries of the LMB; (ii) evaluate the status and trends in fish catch; (iii) monitor spatial and temporal patterns in fish abundance and diversity; and (iv) assess fish community patterns and their relationships with environmental factors.

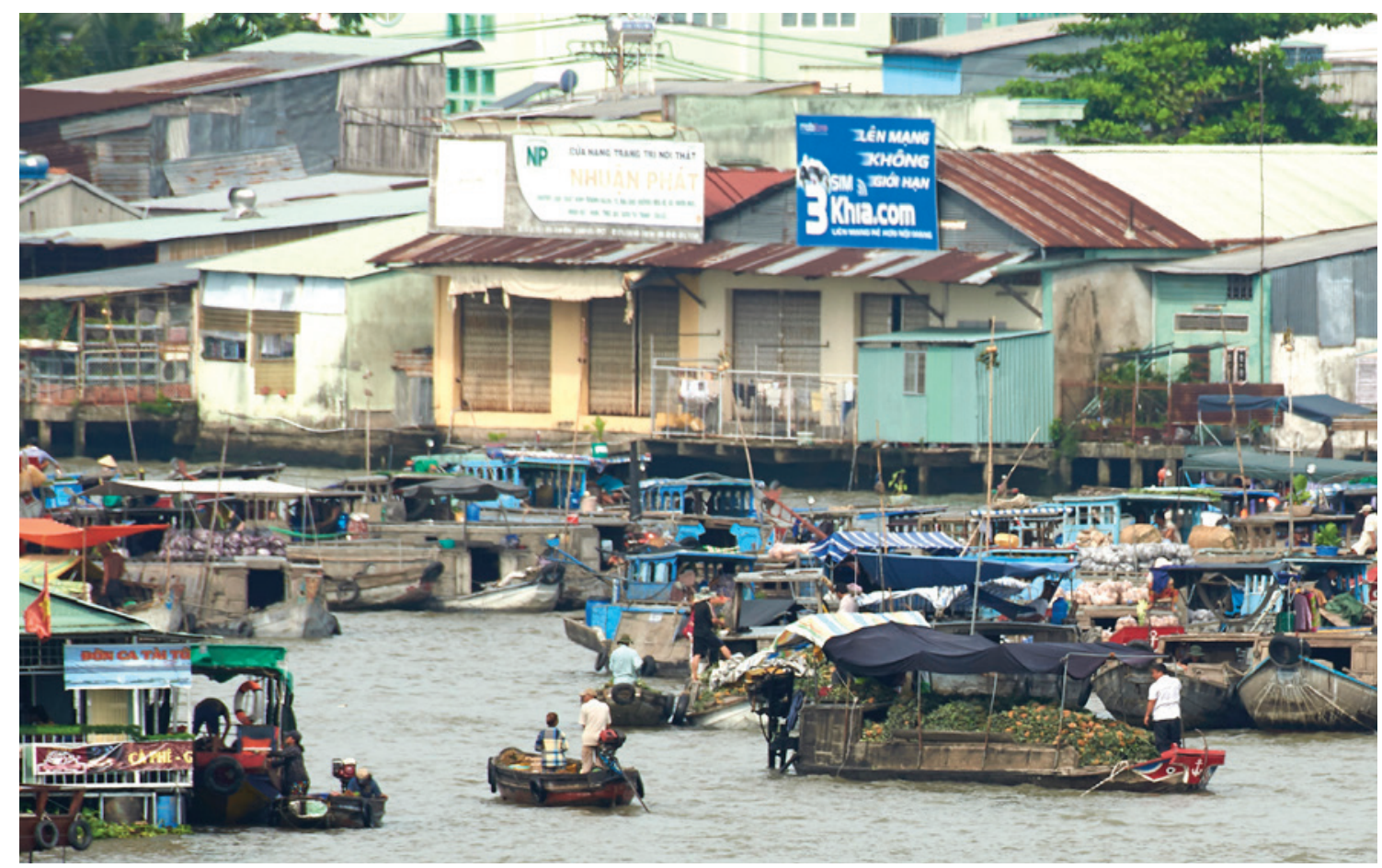


STATUS AND TRENDS OF FISH ABUNDANCE AND DIVERSITY IN THE

LOWER MEKONG BASIN DURING 2007-2018

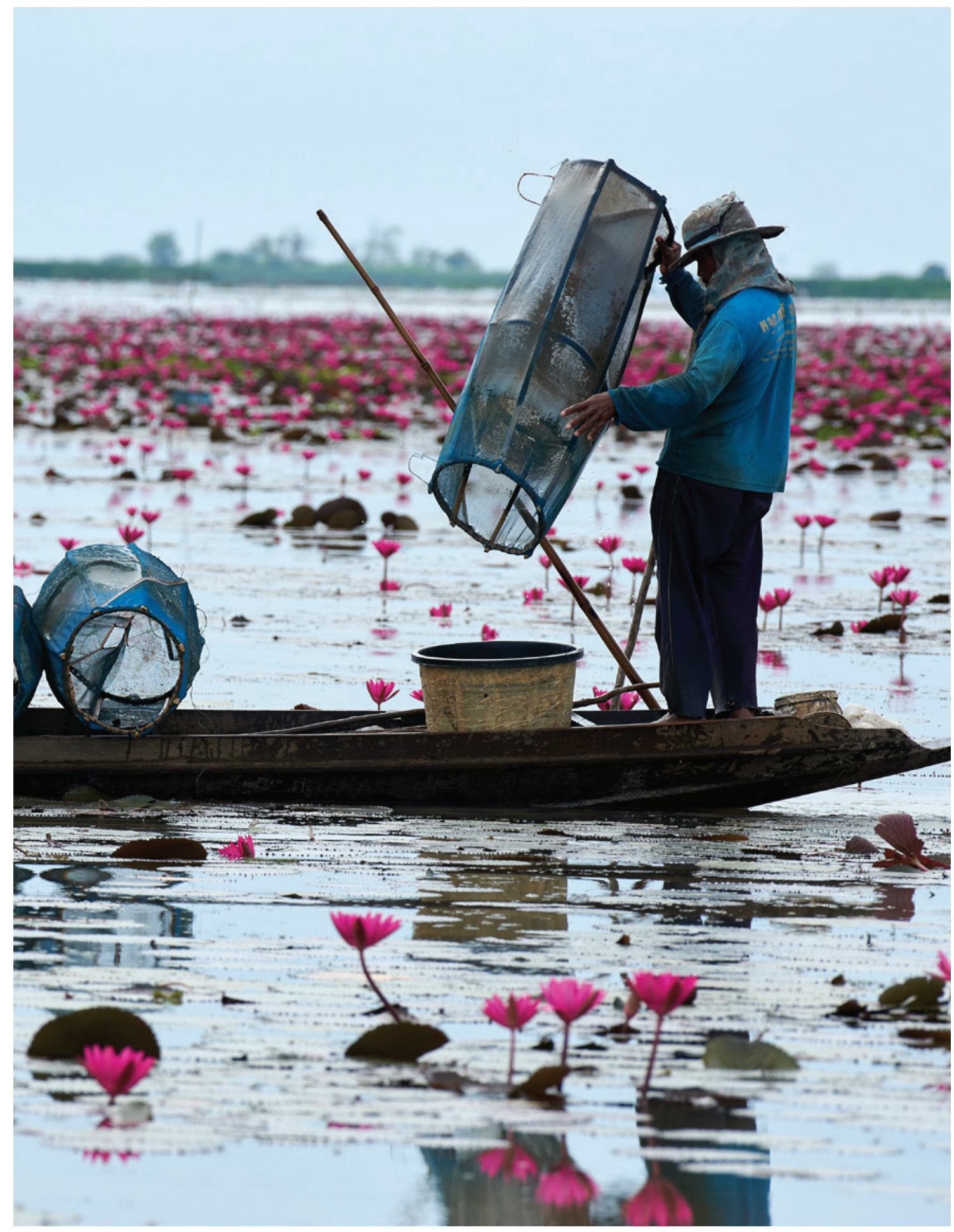




\section{2}

\section{METHODS}

\subsection{MONITORING STATIONS}

There are 38 monitoring stations from Bokeo at the Lao PDR-China border to the Mekong Delta in Viet Nam (Figure 2.1), of which 11 stations are in Cambodia, 15 in Lao PDR, 5 in Thailand and 7 in Viet Nam. The locations of monitoring stations are within each of the main river reaches as defined by the MRC (Figure 2.1) (the characteristics are summarised in Annex 1). The monitoring stations include:

- Sixteen (16) Mekong mainstreams upstream and downstream of mainstream hydropower projects;

- Eleven (11) locations on larger tributaries with significant hydropower development or plans;

- Eight (8) locations in floodplain habitats: five locations in the provinces around Tonle Sap Lake in Cambodia, one location in Nakhon Phanom in Thailand and two locations in the Viet Nam Delta (Can Tho and An Giang provinces);

- Two (2) locations in the estuarine habitat in Tra Vinh province, Viet Nam; and

- One (1) location in the canal habitat in An Giang province, Viet Nam.

All the above monitoring stations, except the 3 S stations (CSK, CSP and CSS) in Cambodia and 2 stations (LAP and LXK) in Lao PDR, were grouped based on BioRA zones of the MRC Council Study as shown in Table 2.1. A detailed description of each zone can be found in the MRC Council Study report (MRC, 2017). 
Note that only 25 stations were included in this study due to the longevity and regularity of the collected data from 2007 to 2018. Of the 25 stations, 11 were in Cambodia, 4 in Lao PDR, and 5 in each of Thailand and Viet Nam. However, for a relationship study between fish communities and environmental factors, only 20 stations (11 stations in Cambodia, 3 in Lao PDR, 2 in Thailand and 4 in Viet Nam) could be used due to the availability of environmental data at those stations.

Table 2.1 Monitoring stations inside each BioRA zone

\begin{tabular}{|c|c|c|}
\hline Zone No. & BioRA Zones & Fisheries Monitoring Stations \\
\hline Zone1 & $\begin{array}{l}\text { Mekong River from the border with China to Pak } \\
\text { Beng (confluence with Nam Beng) }\end{array}$ & LDK, LHT, LPN, LOX \\
\hline Zone2 & $\begin{array}{l}\text { Mekong River from downstream of Nam Beng to } \\
\text { upstream at Vientiane }\end{array}$ & LNS, LPB, LPO, LXB, TCK, \\
\hline Zone3 & $\begin{array}{l}\text { Mekong River from Vientiane to Nam Kam town } \\
\text { (near confluences with Xe Bang Fei and Nam Kam) }\end{array}$ & LBX, LVT, TKR, TSK, TNK, TUT \\
\hline Zone4 & $\begin{array}{l}\text { Mekong River from Nam Kam to Stung Treng (Se } \\
\text { San/Se Kong confluences) }\end{array}$ & CKT, CST, LSD, LCS, LSL \\
\hline Zone5 & $\begin{array}{l}\text { Mekong River from Stung Treng to Kampong } \\
\text { Cham }\end{array}$ & $\begin{array}{l}\text { Note: since there is only one station in } \\
\text { this zone, its station (CKT) is combined } \\
\text { with Zone } 4 .\end{array}$ \\
\hline Zone6 & $\begin{array}{l}\text { Tonle Sap River at Prek dam, plus the Cambodian } \\
\text { floodplains }\end{array}$ & $\begin{array}{l}\text { Note: since there is only one stations in } \\
\text { this zone, its station (CKD) is combined } \\
\text { with Zone } 7 .\end{array}$ \\
\hline Zone7 & Tonle Sap Great Lake and River & CBT, CKC, CPT, CPS, CSR, CKD \\
\hline Zone8 & $\begin{array}{l}\text { The Vietnamese Delta from the Cambodian and } \\
\text { Viet Nam borders to the sea }\end{array}$ & VAP, VCM, VTS, VCT, VTV, VLT, VVL \\
\hline Zone3S & $\begin{array}{l}\text { Sekong, Sesan and Sre Pok rivers in Cambodia } \\
\text { (Note: these zones were not included in the } \\
\text { BioRA) }\end{array}$ & $\begin{array}{l}\text { CSK, CSS, CSP, LAP, LXK } \\
\text { (Note: For further studies, LAP and LXK } \\
\text { might be included in this zone since } \\
\text { both LAP and LXK are located in the } \\
\text { Sekong River.) }\end{array}$ \\
\hline
\end{tabular}

Note:

1. The full names of the stations can be found in Annexe 1.

2. The stations in red text were not included in this study due to insufficient data. 


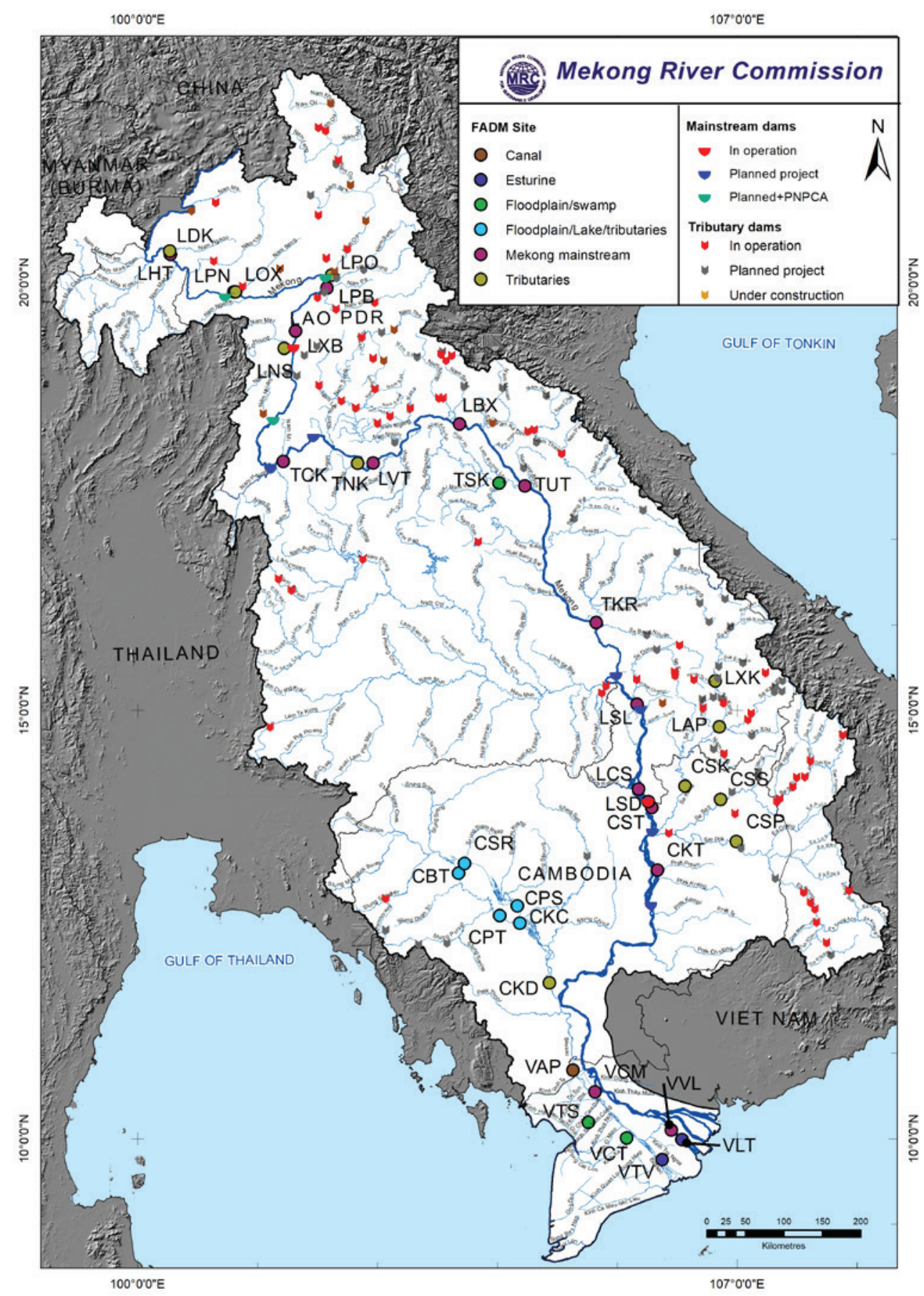

Figure 2.2 Map of the Lower Mekong Basin showing FADM monitoring stations and hydropower dams (Source: MRC fisheries and hydropower database 2019) 


\subsection{FISHER SELECTION}

Three experienced fishers at each monitoring station were selected by national implementing agencies in the four Member Countries. The selected fishers had to meet the following criteria:

1. They are 'typical' medium-scale, full-time fishers at that location. They fish most days of most weeks (>200 days per year) and fishing is their primary occupation for income generation;

2. They fish from motorised boats and use a variety of medium-scale gear, such as gill nets, trammel nets or trawl nets depending on the season. It is recommended that all fishers use gillnets as standardised gear as it enables enhanced comparisons between locations. The mesh size of the gill nets used should be recorded on each occasion to account for selectivity;

3. They are able to read and write;

4. They are willing to participate and be honest in recording fish species and catches;

5. Priority is given to fishers associated with organized fisher groups such as community fisheries or fish refuge pond communities if these types of organisations exist in that location; and

6. Their experience and capacity, including eyesight, is adequate for identifying fish and recording data.

\subsection{SAMPLING TECHNIQUES}

Two sampling and recording techniques were employed; one for the whole sample and another for sub-samples of fish catches. Firstly, if the fish catch is less than $10 \mathrm{~kg}$, fishers sort and weigh their entire catch and record details of the numbers, weights and prices by species and gear. Secondly, in case the catch is large (>10 kg), the whole catch needs to be sub-sampled by recording numbers, weights and prices by species and by gear following recording of the total weight of the catch for all species. In the cases of large-sized fishes (>200 g) and uncommon fish ( $<10$ individuals), after weighing the total catch of all species, their total weight and number are recorded separately. The remaining small-sized fishes are thoroughly mixed and formed into a neat pile. This pile is then divided into 12 equal piles and combined into 3 or 6 piles depending upon its size. The total weight of all the mixed fish in either one half or one quarter of the pile is recorded and then the numbers, weights and prices of fish by species in the catch sample are recorded. The details of these techniques are described by Cowx, Nuon, and So (2019). 


\subsection{DATA COLLECTION}

The daily fish catch data were collected by the participating fishers using various types of fishing gear (e.g. cast nets, hooks and lines, and gillnets). Note that the fishers employ about 26 types of fishing gear (Cowx, Nuon, \& So, 2019), but gillnets are the most commonly used by fishers within all the major habitat types and during most months in all four countries. At each station, the fishers recorded their daily catches in logbooks including individual weights, total weights, number of fishes, maximum length of each species, and weather and hydrological conditions on each fishing day. To support fishers with fish identification, fish photo books (or flipcharts) are provided and identification is made to species level. Data are cross-checked against the contents of the logbook and cleaned by fisheries researchers from national fisheries research agencies each quarter. Moreover, the data are double-checked for errors (e.g. outliers and missing data...) by a Fisheries and Aquatic Ecology Officer of the Environmental Management Division at the MRCS every six months.

MRC survey data collected over twelve years from 2007 to 2018 were considered in this report except for stations in Tonle Sap Lake, where sampling began in 2011. Figure $\mathbf{2}$. 2 shows the matrix of the 25 monitoring stations selected across the time period. The missing values between 2015 and 2016 were caused by financial shortages during restructuring of the MRCS.

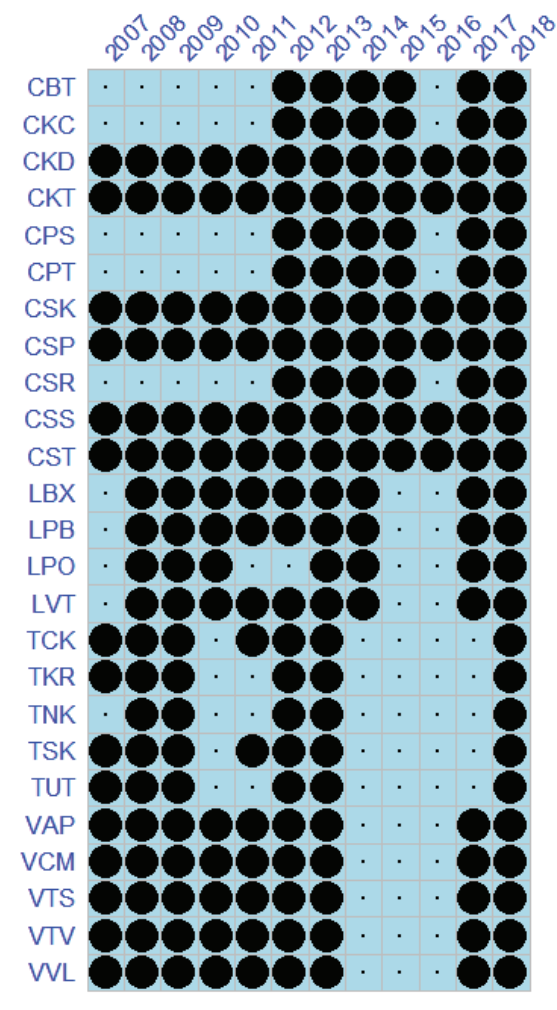

Figure 2.3 Sampling activity at each of the 25 stations across the survey period from 2007 to 2018 (big black circles).

Note:

Small dots indicate missing data 


\subsection{DATA ANALYSIS}

\subsubsection{Catch rate, Catch Per Unit Effort (CPUE)}

For catch rate (CPUE), data were analysed to determine catch rates according to:

- Mean catch rates for a group of species; and

- Comparison of the mean catch rates for the different locations, seasons and habitats.

All data were reported as $\mathrm{kg} / 100 \mathrm{~m}^{2} /$ hour for gillnets with a specific mesh size or all mesh sizes used by selected fishers and presented in graphs for each station clustered according to the Council Study's BioRA zones. To achieve this, all catch data were standardised for number or size of gear used; for example, for gillnets, catches were standardised as catch/100 $\mathrm{m}^{2} /$ hour of net area.

\subsubsection{Fish species richness and diversity in the LMB}

Species richness and occurrence as well as species diversity were examined spatially at station (alpha diversity) or BioRA zone (gamma diversity) levels, and temporally (beta diversity) during the 12-year survey period. Spatial and temporal changes in fish species diversity in the LMB were studied by two diversity indices: Inverse Simpson and Shannon-Wiener. Pielou's evenness index was also used to show how close the numbers of each species were at each station in an environment. The regional diversity at each BioRA zone was indicated by the Shannon-Wiene Index.

Rank-species and rank-abundance curves of fish at each station were used to visualize species richness and evenness. Species richness can be shown as the number of different species on the chart; i.e., how many species were ranked. Species evenness is reflected in the slope of the line that fits the graph (assuming a linear, i.e. logarithmic series relationship). A steep gradient represents low evenness as the high-ranking species have much higher abundances than the low-ranking species. A shallow gradient illustrates high evenness as the abundances of different species are similar.

The Species Accumulation Curve or Species Discovery is a graph showing the cumulative number of species recorded in a particular environment as a function of the cumulative sampling effort. The curve can also reveal the number of additional species that will be discovered with further effort. This is usually done by fitting some kind of functional form to the curve, either by eye or by using non-linear regression techniques. Commonly used functional forms include the logarithmic function and the negative exponential function. The advantage of the negative exponential function is that it tends to an asymptote which equals the number of species that would be discovered if infinite effort is expended. However, some theoretical approaches imply that the 
logarithmic curve may be more appropriate implying that although species discovery will slow down with increasing effort, it will never entirely cease; therefore, there is no asymptote, and if infinite effort was expended, an infinite number of species would be discovered. The Species Accumulation Curve was used for LMB data at BioRA zones to appreciate the richness of fish discovered relating to the effort over time.

\subsubsection{Temporal change in fish diversity and abundance in the LMB}

Beta Diversity was used to indicate the variation in species composition among stations in an area of interest (e.g. monitoring stations) or among survey times for a survey across years (Legendre \& De Cáceres, 2013). Before measuring total beta diversity $\left(\mathrm{BD}_{\text {total }}\right)$, the species abundance/ community composition data were transformed and then $\mathrm{BD}_{\text {Total }}$ was computed on Hellingertransformed data, having a value ranging from 0 to 1 . If the sampling units/stations are the same size, $\mathrm{BD}_{\text {Total }}$ was compared among study stations (Legendre \& Salvat, 2015). Once all sampling units/stations have different species compositions, $\mathrm{BD}_{\text {Total }}$ is equal to 1 .

$\mathrm{BD}_{\text {total }}$ was partitioned into Local Contributions of individual site to Beta Diversity (LCBD) and Species Contributions to Beta Diversity (SCBD). LCBD are comparative indicators of station uniqueness; thus, stations with significantly different species compositions have high values of LCBD. SCBD is essential to define which species show huge variations across the monitoring station. Note that SCBD and indicator species for groups of stations do not have the same interpretation (De Cáceres \& Legendre, 2009; Dufrêne \& Legendre, 1997).

\subsubsection{Patterns of fish community in the LMB}

Hierarchical clustering on the Hellinger-transformed species data was used to partition the monitoring stations into different groups based on their similarity of species composition. The species richness and diversity index (i.e. inverse Simpson index) of each group (cluster) was computed and then significant differences $(p<0.05)$ among groups were tested using KruskallWallis and Tukey's Honest Significant Difference (HSD) tests. Afterwards, the indicator species of each group of stations were determined using the "indicspecies" package to describe the differences in the clusters identified (De Cáceres et al., 2010). For a given group, the indicator value of the species is the square root of the product of two quantities called $A$ and $B$, that is: predictive value and sensitivity. Quantity $A$ is the probability of the target group of stations given that an individual species has been found and was defined as the mean abundance of the species in the target station group divided by the sum of the mean abundance value over all groups. Quantity B is the average relative abundance of individuals of the species at a station that belongs to the target station group and was determined as the relative frequency of occurrence of the species inside the target station group (De Cáceres et al., 2010). Hence, species with high indicator values were used as characteristic members of the group. 


\subsubsection{Abundance/Biomass Comparison (ABC) Curve}

The ABC curve method was proposed by Warwick in 1986. Theoretically, he mentioned that the distribution of the numbers of individuals among species should differ from the distribution of biomass among species when influenced by pollution-induced disturbance. This difference can be shown easily by K-dominance plots (Lambshead et al., 1983; Shaw et al., 1983).

This method involves the plotting of k-dominance curves for species abundances and species biomasses on the same graph and making a comparison of these curve forms. The species ranked in order of importance in terms of abundance or biomass on a logarithmic scale ( $x$ - axis) against percentage dominance on a cumulative scale ( $y$ - axis). The relative position of these curves has been suggested as a measure of the degree of stress. There are three levels of environmental disturbance: Under an unstressed environment the biomass curve overlies the abundance curve for its entire length as an indication of the dominance of a few large species (k-selected species). In a highly stressed environment, the abundance curve overlies the biomass curve as a result of numerical dominance of a few opportunistic species with small body sizes ( $r$-selected species). Under moderate disturbance, the biomass and abundance curves are closely coincident and may cross each other one or more times. The degree and direction of the separation of these curves, which represents the area between the two curves is given by the $\mathrm{W}$ - statistic and expressed as:

$$
W=2(p A-p B) /(S-1)
$$

in which; pA and pB are the "Average Species Rank" for abundance and biomass;

$\mathrm{S}$ is the number of species; and

$\mathrm{W}$ is the statistic that takes values in the range (-1 to 1$)$ with $\mathrm{W}$ close to 1 for equal abundances across species but biomass dominated by a single species, and $W$ close to -1 for the converse case indicating that the biomass curve lies below the abundance curve and thus the more stressed the community and degraded the system. The ABC curves were drawn using the statistical package "forams" within R environment.

\subsubsection{Relationship between fish species and environmental factors}

To elucidate the relationships between biological assemblages of species and their environment, Canonical correspondence methods were used. The multivariate method is designed to extract synthetic environmental gradients from ecological datasets. The gradients are the basis for succinctly describing and visualizing the differential habitat preferences (niches) of taxa via an ordination diagram (Legendre \& Legendre, 2012).

Redundancy Analysis (RDA) is a method to extract and summarise the variation in a set of response variables that can be explained by a set of explanatory variables. More accurately, RDA is a direct gradient analysis technique which summarises linear relationships between components of 
response variables that are "redundant" with (i.e. "explained" by) a set of explanatory variables. To do this, RDA extends multiple linear regression (MLR) by allowing regression of multiple response variables on multiple explanatory variables. A matrix of the fitted values of all response variables generated through MLR is then subject to principal components analysis (PCA). See Jongman, Braak, and Tongeren (1995) for details.

RDA can also be considered as a constrained version of Principal Components Analysis (PCA), wherein canonical axes - built from linear combinations of response variables - must also be linear combinations of the explanatory variables (i.e. fitted by MLR). The RDA approach generates one ordination in the space defined by the matrix of response variables and another in the space defined by the matrix of explanatory variables. Residuals generated by the MLR step, which yield non-canonical axes, may also be ordinated. Detailed discussion is available in Legendre \& Legendre (2012).

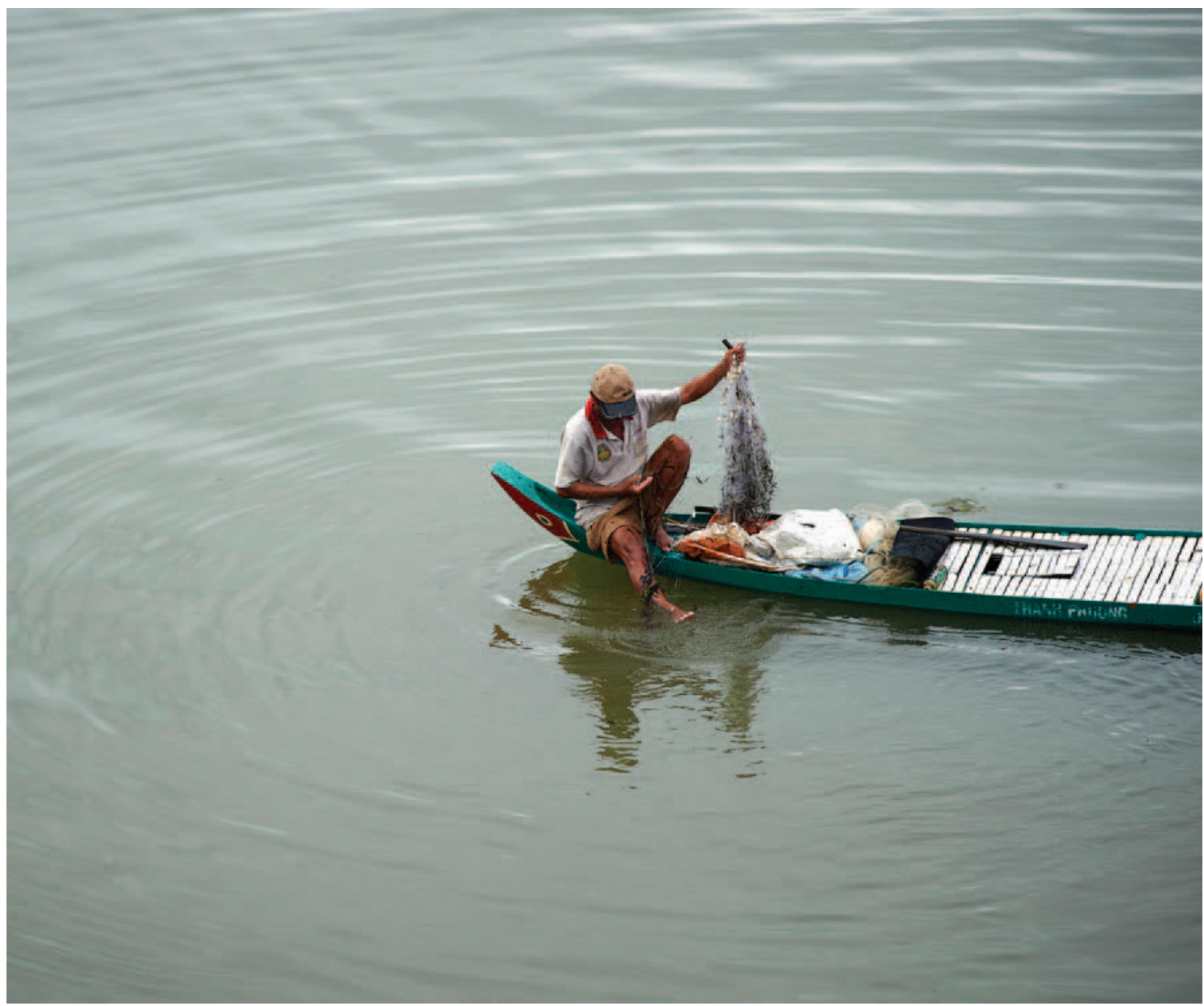


STATUS AND TRENDS OF FISH ABUNDANCE AND DIVERSITY IN THE

LOWER MEKONG BASIN DURING 2007-2018

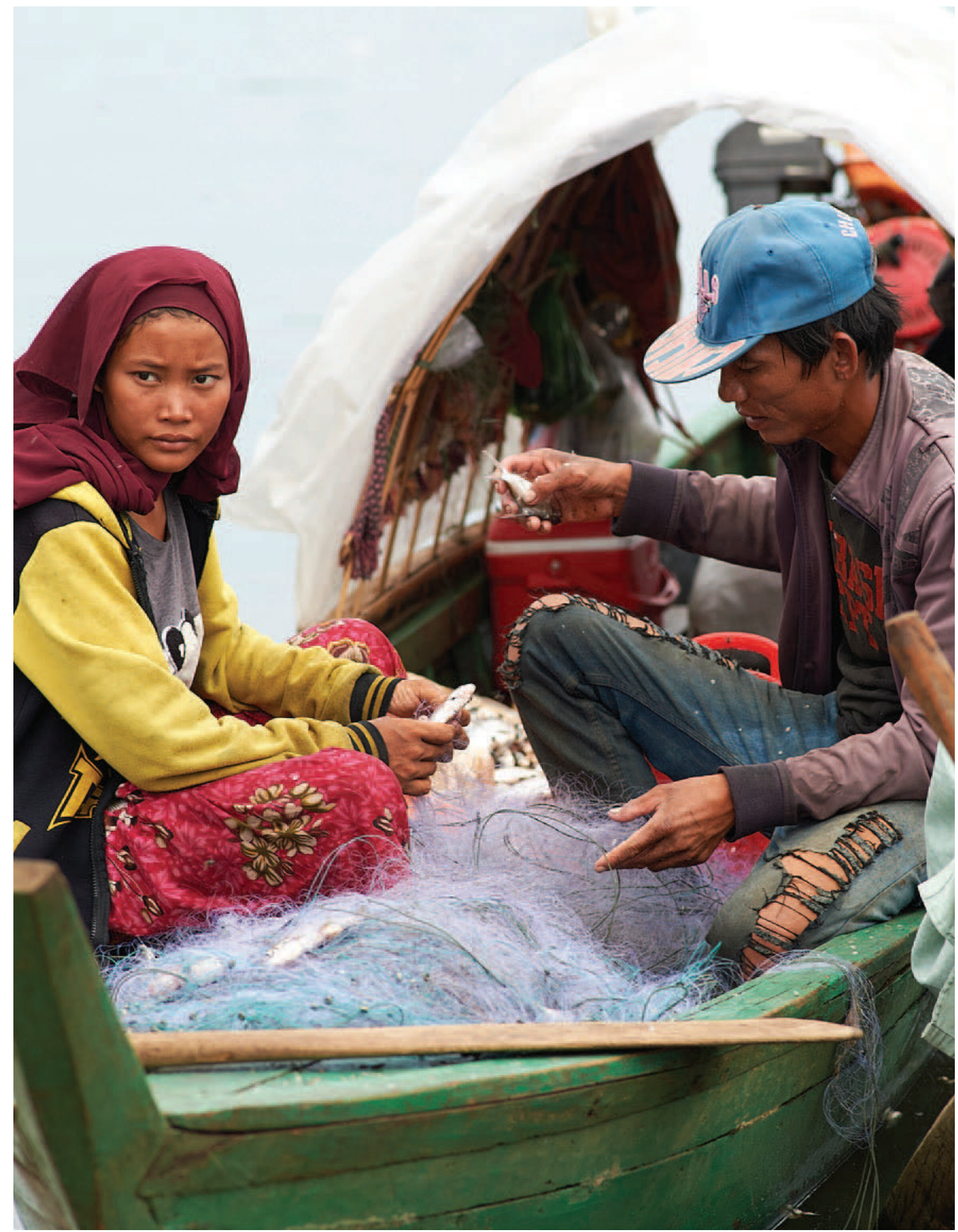




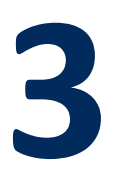

\section{RESULTS}

\subsection{CONTRIBUTION OF FISH SPECIES AND GUILDS TO THE FISHERIES OF THE LMB}

\subsubsection{Basin-wide fish catch}

During the survey period in the LMB from 2007 to 2018, the FADM recorded 37,530,460 individuals, corresponding to 1,095,848 Kg of fishes belonging to 21 orders, 80 families and 617 species (Annex 4). Note that the above record is pooled from all the existing data from 38 stations disregarding the time of data collection since the purpose is to show the actual number and catch of fish (i.e. relative abundance and biomass, respectively) and species caught from 2007 to 2018. Figure 3.1 shows clearly the dominance of three orders, with Cypriniformes representing more than $45 \%$ of the total catch in the LMB, followed by Perciformes and Siluriformes accounting for $40 \%$ of the catch. 


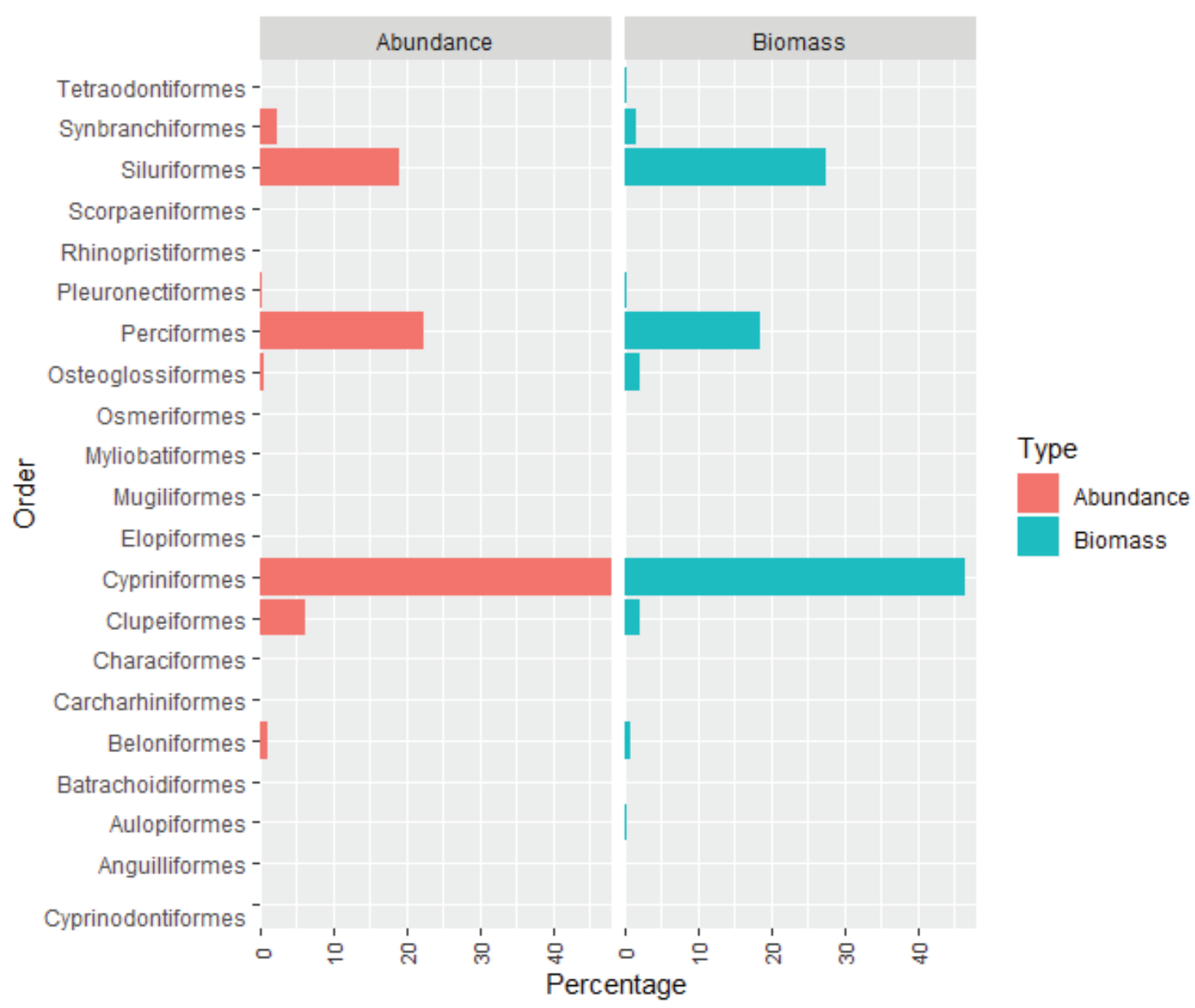

Figure 3.1 Relative abundance and biomass per fish order in the LMB

At the family level, LMB fishes were largely dominated by Cyprinidae making up more than $40 \%$ for both relative Abundance and Biomass (Figure 3.2). The other families accounted for less than $10 \%$ each. It should be noted that the relative abundance of the family Osphronemidae, Bagridae, and Anabantidae was higher than 5\% each, while Bagridae, Pangasiidae and Ariidae accounted for more than $5 \%$ of biomass. The other families were scarce (Figure 3.2). 


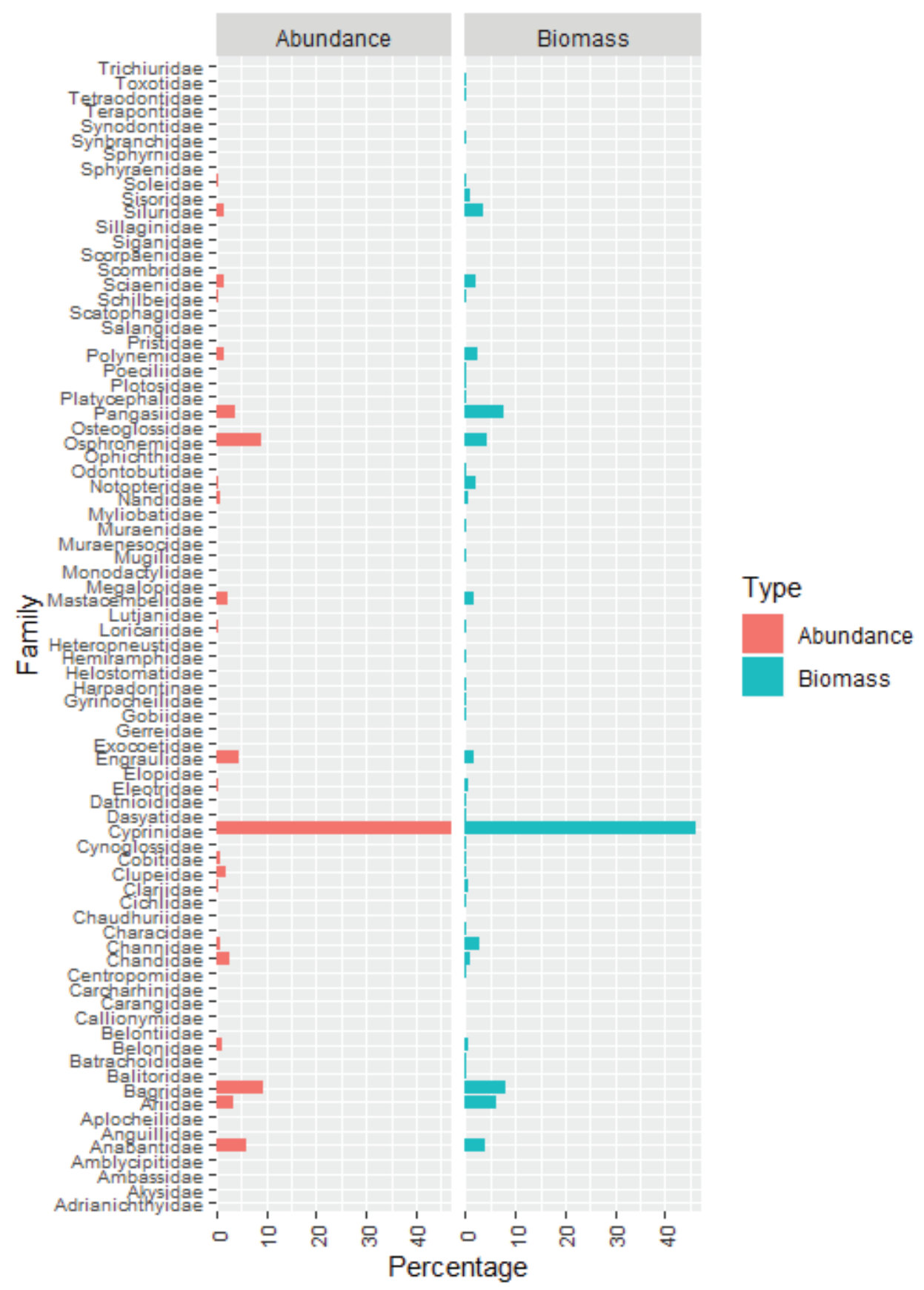

Figure 3.2 Relative abundance and biomass per fish family in the LMB 


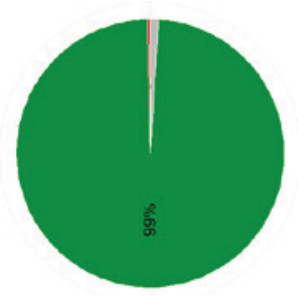

c
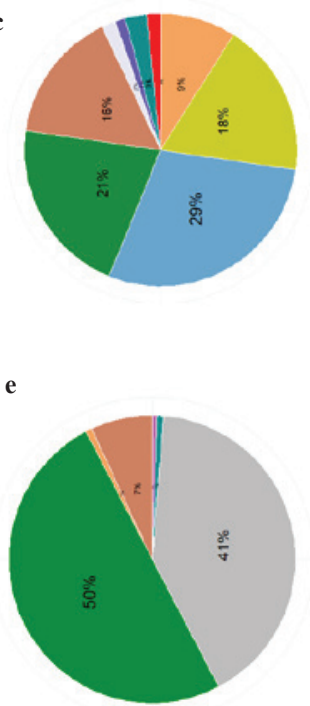

b

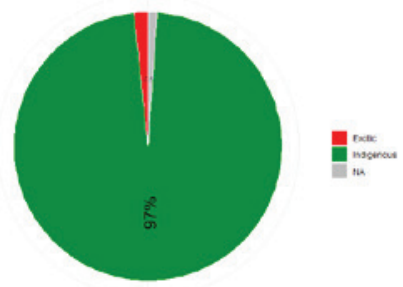

d

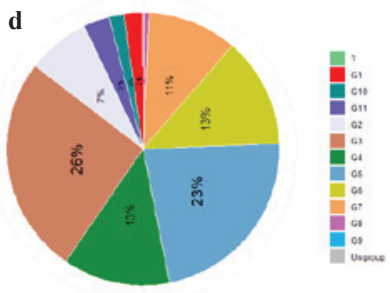

$\mathbf{f}$

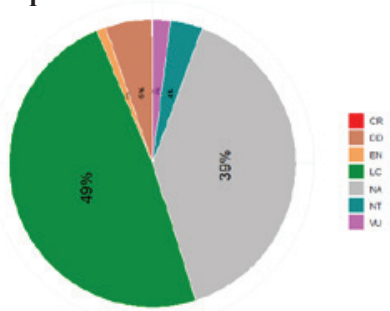

Figure 3.3 Relative abundance and biomass of fish in the LMB in relation to ecological functional characteristics. The left side represents relative abundance and the right side relative biomass

$a-b)$ Invasion status (Exotic or Indigenous);

c-d) ecological functional guilds (G1= Rhithron residents; G2=Main-channel residents or long-distance white fishes;

G3=Main-channel spawners or short-distance white fishes; G4=Floodplain spawners or grey fishes; G5=Eurytopic or generalist fishes; G6=Floodplain residents or black fishes; G7=Estuarine residents; G8=Anadromous fishes;

G9=Catadromous fishes; G10=Marine visitors; G11= Non-Native).

e-f) conservation status (LC: Least Concerned, EN: Endangered, DD: Data Deficient, CR: Critically Endangered, VU: Vulnerable, NT: Near Threatened, NA: fish having not assessed in the IUCN Red list). 
Figure 3.3 shows the catch proportions of LMB fish according to three ecological functional characteristics: native or non-native species, fish guilds and IUCN status. During the survey period, the indigenous species were largely dominant in the LMB with exotic species representing less than $1 \%$ for the relative abundance or number of individuals (Figure 3.3a) and only $1.6 \%$ in the relative biomass or catch (Figure 3.3b).

Relating to the functional guilds, the generalist fishes (G5) were dominant in the catch in terms of relative fish abundance followed by the floodplain spawners or grey fishes (G4) and the floodplain residents or black fishes (G6), with almost equal abundance (Figure 3.3c and Figure 3.3e). However, for the relative biomass, it was observed that the main-channel spawners or short-distance white fishes (G3) was the dominant guild followed by the generalists G5 (Figure 3.3d).

In regard to conservation status, the majority of the LMB fish species are in the Least Concerned (LC) category for both relative abundance and biomass (Figure 3.3e and Figure 3.3f). Near Threatened (NT), VUlnerable (VU), ENdangered (EN) and Critically Endangered (CR) fish species each represent less than $1 \%$ of the catch.

\subsubsection{Rank species relative abundance distributions}

A species abundance model is generated by graphing the abundance of each species against its rank order abundance from highest to lowest. One of four distributions usually arise: Log normal distribution, Geometric series, Logarithmic series, and McArthur's broken stick model (Magurran, 2004; Whittaker, 1965).

In the LMB, the species' relative abundance distributions resulting from the 25 FADM stations are shown in Figure 3.4. It clearly shows two different patterns: one group of stations (red-brown lines) with high relative abundance and richness. The differences of shape between stations in this group were linked to the degree of relative abundance of the species in the community. So, for example the convex shape of CKT, CST, and several stations from Tonle Sap indicated a good ecosystem with a community in equilibrium since their distributions were a log-normal distribution. However, another group of stations in the upper part of the LMB in Lao PDR and Thailand revealed more or less a straight-line shape (blue colour), meaning that their distribution could be explained by the dominance of a few species. Moreover, the stations in the Mekong Delta had the distribution between the two groups. 


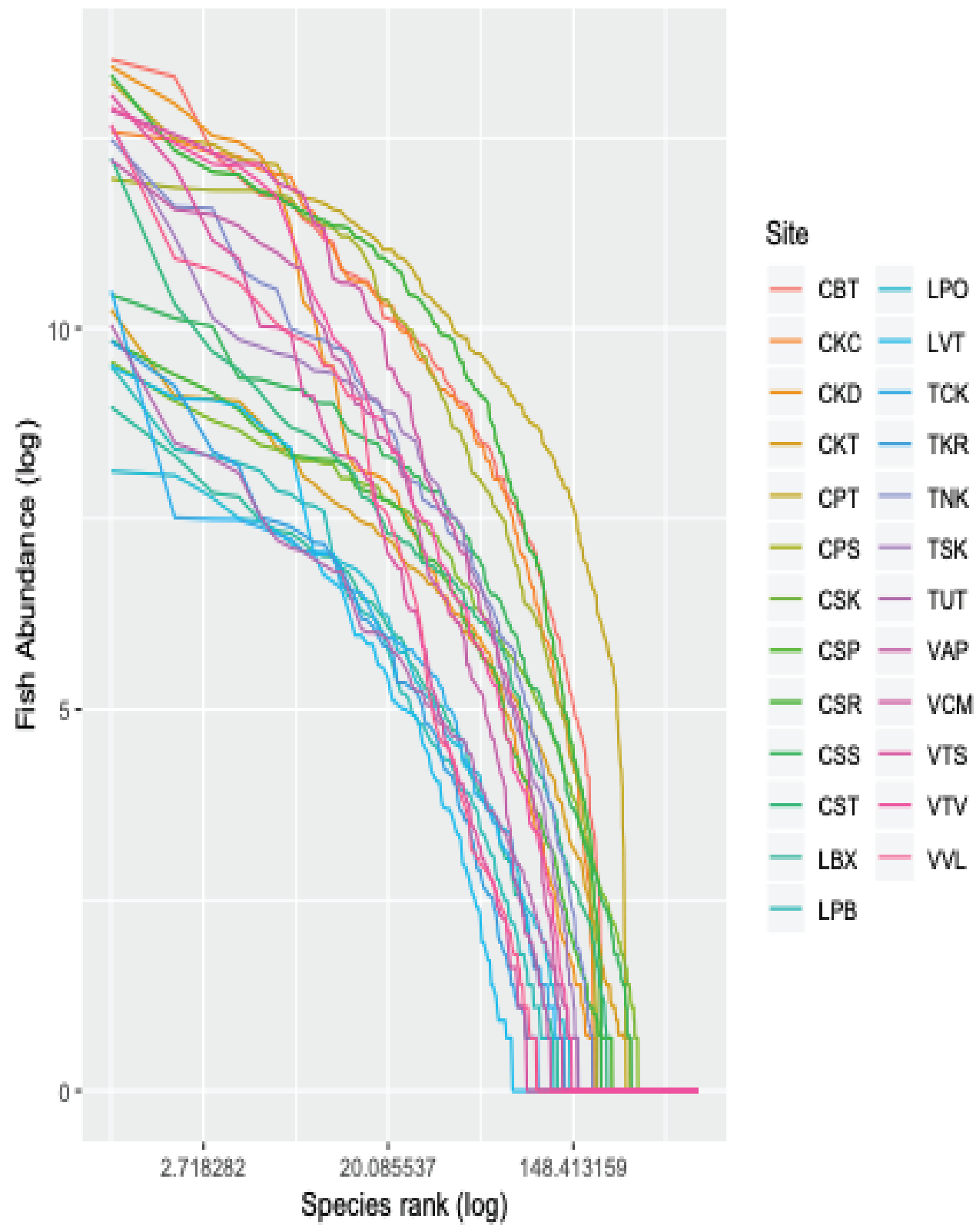

Figure 3.4 Rank species relative abundance distributions of FADM stations in log-log scale 


\subsubsection{Dominant species in relationship with relative abundance}

By comparing the rank species relative abundance of fish composition for each station in the $L M B$, the dominant fish species of the five stations in Tonle Sap Lake, followed by the two stations in Mekong Delta and CKD in Tonle Sap River can be clearly observed (Figure 3.16a). The other five stations - two in Thailand (TNK and TSK) and three in the Mekong Delta (VTS, VAP and VVL) - had a relatively high rank of relative abundance. The 12 stations in the upper part of the LMB had very low rankings for fish abundance (Figure 3.5a).

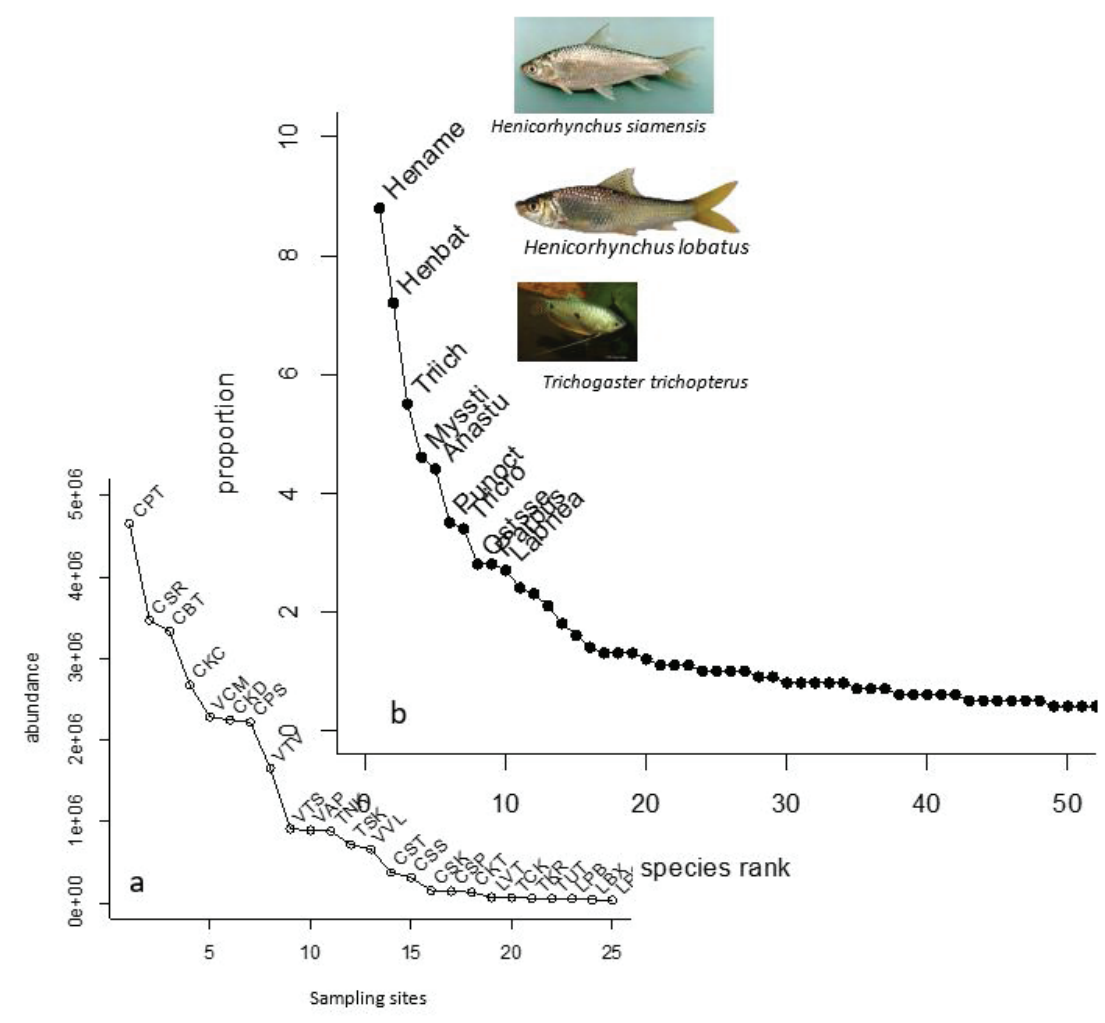

Figure 3.5 Site-rank relative abundance in the LMB; (a) the decreasing order of fish abundance by station; (b) the decreasing order of the abundance of fish species

The rank species relative abundance curve in the LMB (Figure 3.5b) clearly show the dominance of three species:

- Henicorhynchus lobatus;

- Henicorhynchus siamensis; and

- Trichogaster trichopterus. 
These fishes are small-sized species The observed maximum size is not larger than $15 \mathrm{~cm}$ with a common size of around $10 \mathrm{~cm}$.

Figure 3.6 shows the rank-abundance species at each BioRA zone. Three zones (Zone 2, Zone 3, and Zone 4) were largely dominated by only one species: Sikukia gudgeri in Zone 2 at the upstream of the LMB (Figure 3.6a); Henicorhynchus siamensis in Zone 3 (Figure 3.6b); and Henicorhynchus lobatus at Zone 4 (Figure 3.6d). However, the 35 (Zone 3S), the Tonle Sap (Zone 7) and the Mekong Delta (Zone 8) had several dominant species in the community (Figure 3.6c, Figure 3.6e and Figure 3.6f). The abundance and richness in these zones were much better balanced.
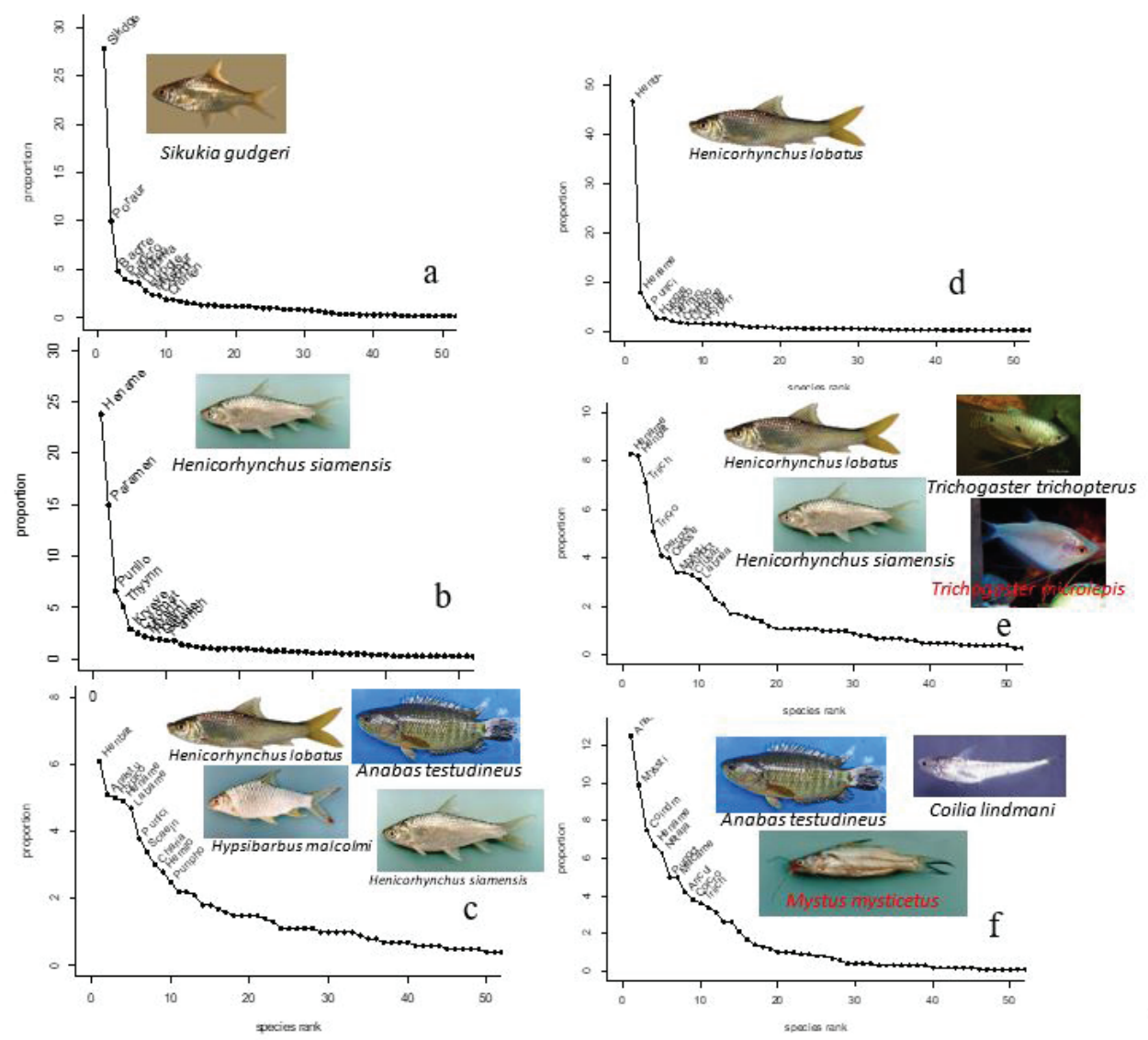

Figure 3.6 Rank-abundance distribution curve in each BioRA zone: a) Zone 2; b) Zone 3; c) Zone 3S; d) Zone 4; e) Zone 7; f) Zone 8

Note:

The most dominant species are shown at each BioRA zone 


\subsubsection{Relationship between relative abundance and relative biomass in LMB}

Figure 3.7 shows the relationship between relative fish abundance and biomass in the LMB during the FADM period from 2007 to 2018. Figure 3.18 shows the exponential shape of the relationship between observed fish abundance and biomass recorded by fishers in the LMB. This positive effects of species abundance on productivity confirm the high resource availability in LMB (Fridley, 2003; He et al., 2002).

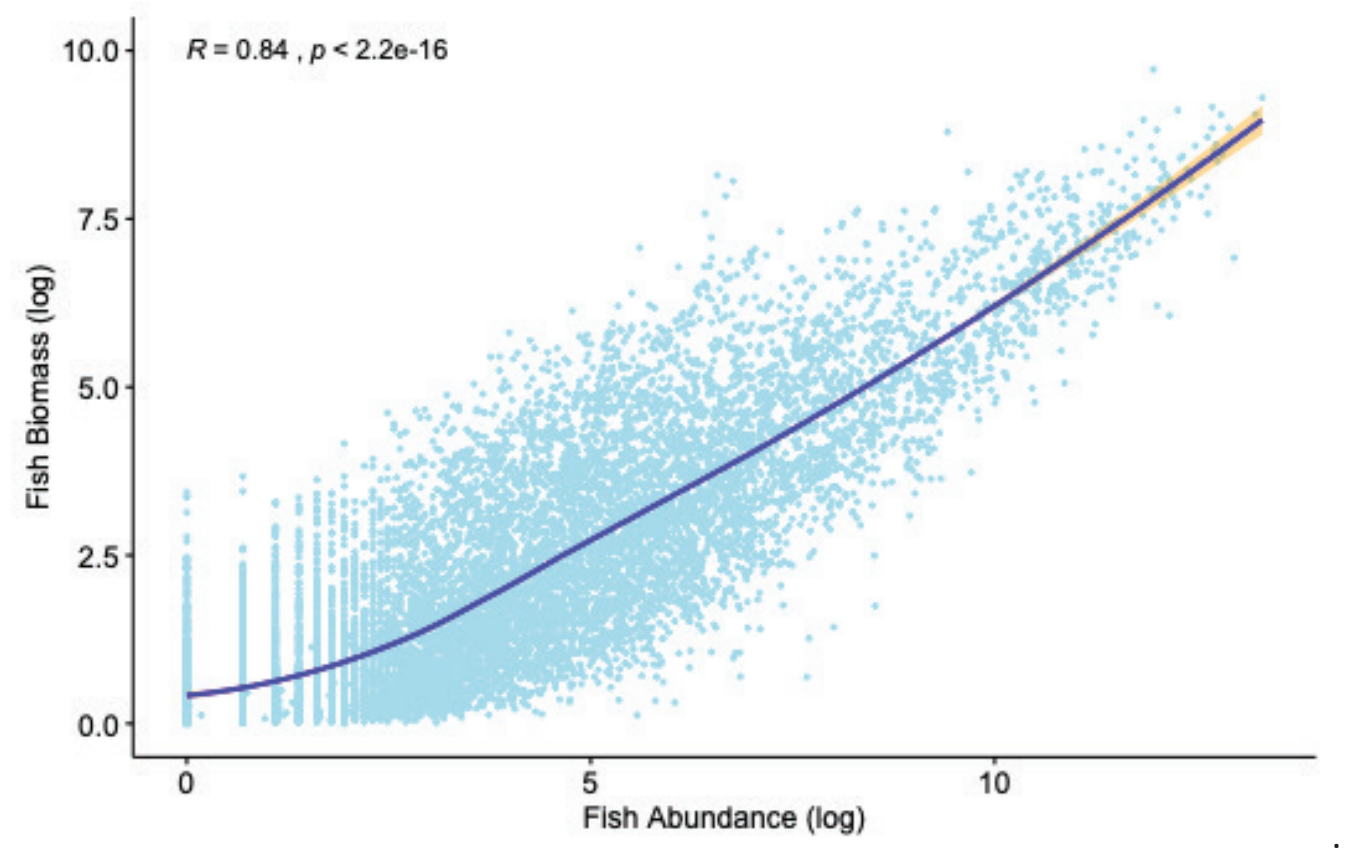

Figure 3.7 Scatterplot of relative biomass as a function of relative abundance of fish in the LMB during the FADM period, fitted by Loess smoothing

\section{Relationship between species abundance and biomass in the LMB}

The relationship between abundance and biomass of the 571 species caught from 25 monitoring stations during the FADM period from 2007 to 2018 is presented in Figure 3.8. The two species of Henicorhynchus ( $H$. siamensis and $H$. lobatus) were the most abundant and provide the maximum biomass in the LMB fisheries (Figure 3.8a). A group of four other fish species were also well represented: Anabas testudineus, Mystus mysticetus, Trichogaster trichopterus and Puntioplites proctozysron. Trichogaster microlepis and Coilia lindmani were relatively abundant but with lower biomass. Osteochilus hasselti, Netuma thalassinus, Barbonymus gonionotus, Labeo chrysophekadion, Cosmochilus harmandi, Polynemus longipectoralis, and Arius maculatus 
had high biomass but lower abundance. The remaining species were low in both abundance and biomass (Figure 3.8a). This is a typical log-normal distribution of a mature ecosystem.

To linearize the relationship between fish biomass and abundance, the log-log scale was used. Figure $3.8 b$ shows clearly the strong linear relationship between species abundance and species biomass in the LMB fisheries, which means the LMB is a mature ecosystem with a high level of resources.
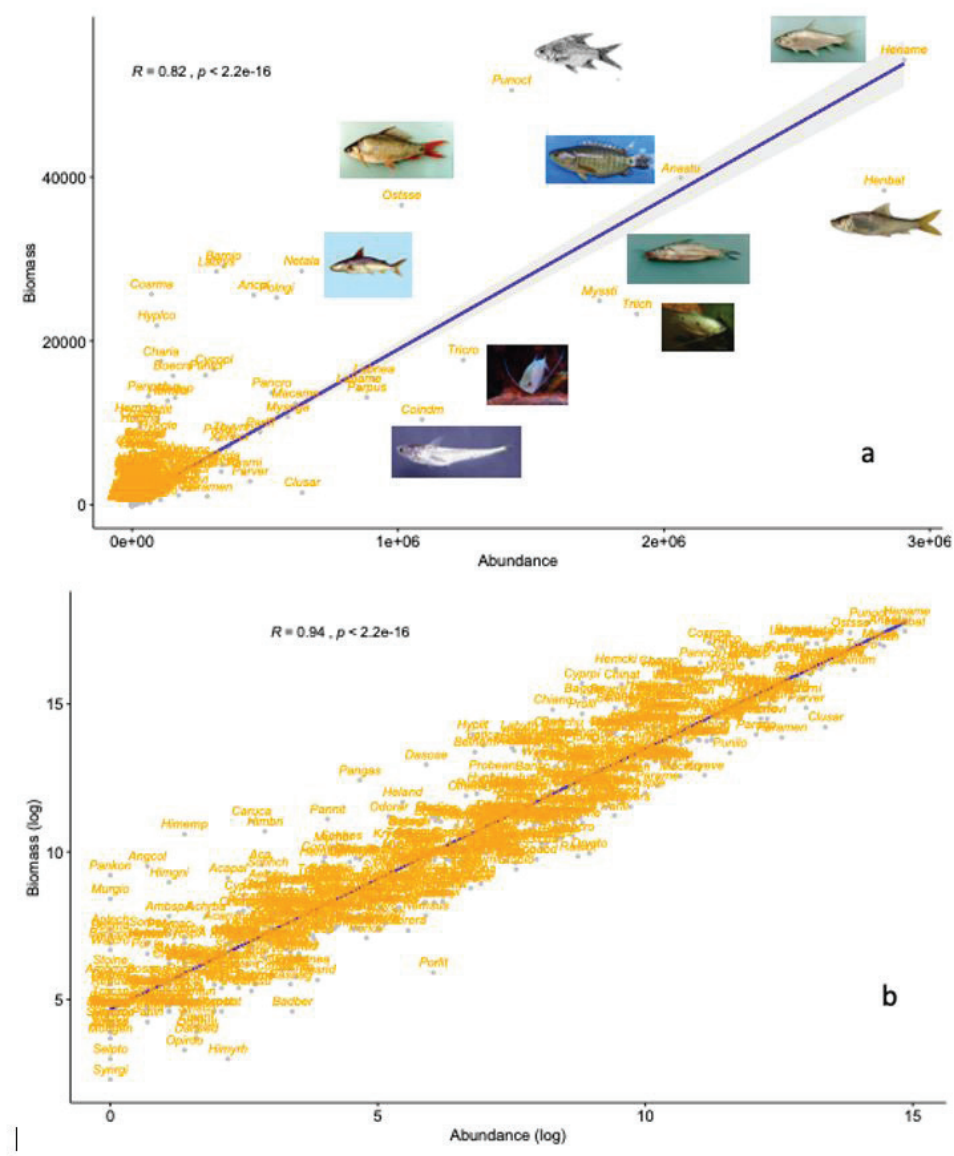

Figure 3.8 Scatterplot between yearly species abundance and species biomass from all FADM monitoring stations

Note:

a) normal scale showing the dominant species; b) log-log scale showing the trend of the linear relationship between abundance and biomass 


\subsection{STATUS AND TRENDS OF FISH CATCH IN THE LMB}

\subsubsection{Fish Abundance-Biomass Curves $(A B C)$ in the $L M B$}

The relative Abundance-Biomass Curve (ABC) (Warwick, 1986) was used to evaluate the quality of the river ecosystem. It is well known that this method should be a sensitive indicator of natural physical and biological disturbance as well as of pollution-induced disturbance in both space and time.

The $A B C$ showed clearly that the fish community in the LMB was moderately disturbed due to the biomass curve situated under the abundance curve, meaning that the LMB fisheries are dominated by some small-sized and short-lived fish species (Figure 3.9). The negative values of $W$ show clearly that the LMB ecosystem is under stress.

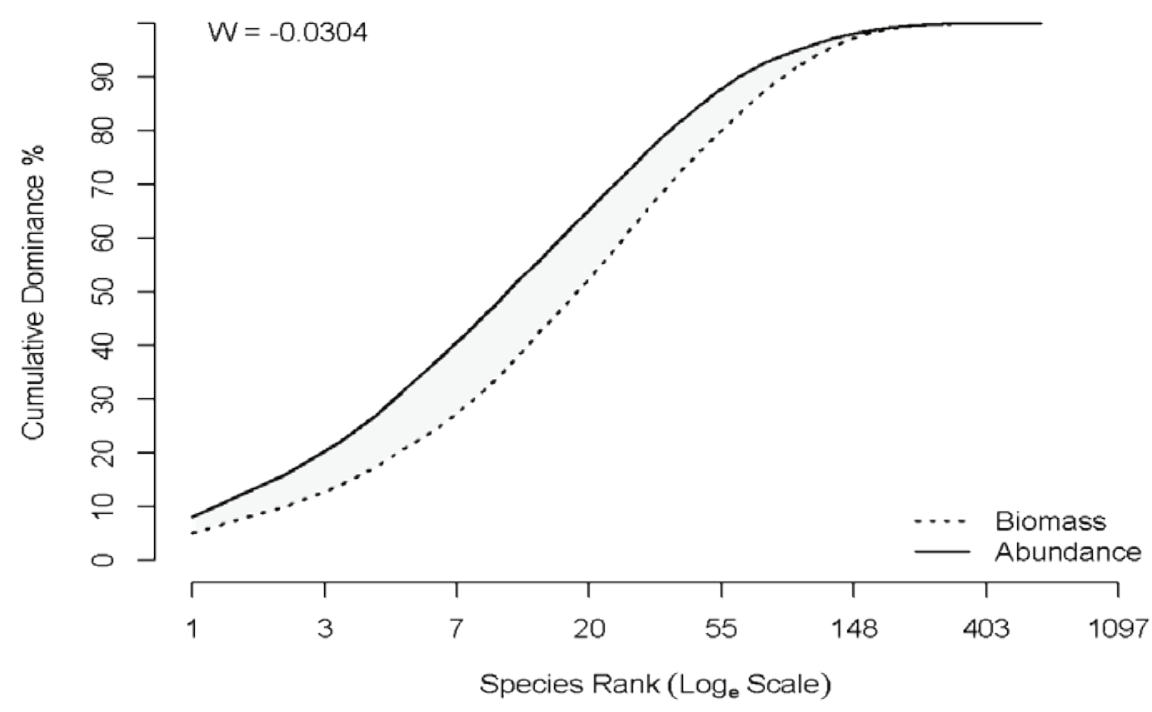

Figure 3.9 The relative Abundance-Biomass Curve $(A B C)$ of the LMB

The spatial ABC curves of the 7 BioRA zones are presented in Figure 3.10. Except for Zone 3S, all zones had negative $W$ values, meaning that these zones are under stress. The highest stress was observed at Zone 2 and Zone 4 with the abundance curve largely placed above biomass, and the areas mostly dominated by small species. Zone $3 S$ was the unique zone in the LMB with positive W-values and a biomass curve over abundance. The system was in better condition or healthy, close to a natural unstressed system (Figure 3.10). The four other zones (Zone 2, Zone 3, Zone 7 and Zone 8) were considered as moderately stressed systems. 

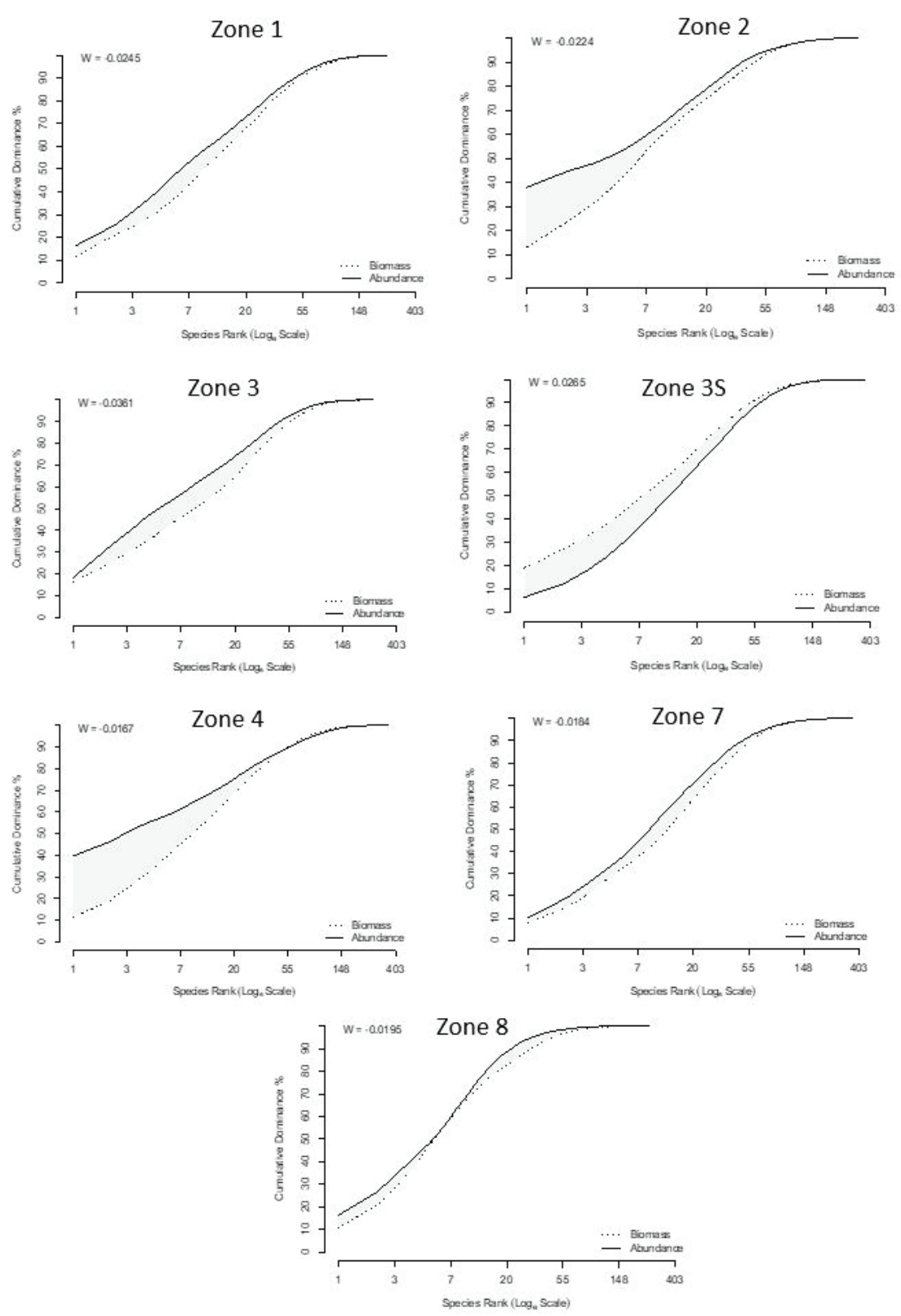

Figure 3.10 Spatial variation of the $A B C$ curve in each BioRA zone of the $L M B$ 


\subsubsection{Fish Catch Rate (CPUE)}

This section describes the changes in fish catch rates at the 25 monitoring stations grouped under the six BioRA zones of the Council Study.

\section{(a) Zone 2: Mekong River from downstream of Nam Beng to upstream at Vientiane}

Zone 2 comprised three stations; two in Lao PDR (LPB and LPO) and one in Thailand (TCK). Note that the CPUE of TCK cannot be compared with other stations since the gear used in that station was stationary gillnets with two layers of nets. The purpose to show the CPUE of this station is to present the catch rate status of that station only. In TCK, the CPUE value ranged from 0.01 to 3.4 $\mathrm{kg} / 100 \mathrm{~m}^{2} /$ hour and steadily dropped over the monitoring period (Figure $3.11 \mathrm{a}$ ). The CPUE of LPB and LPO was from 0.01 to $0.4 \mathrm{~kg} / 100 \mathrm{~m}^{2} /$ hour and from 0.02 to $0.2 \mathrm{~kg} / 100 \mathrm{~m}^{2} /$ hour, respectively. It was observed that only the CPUE of LPB had an upward trend over the monitoring period. The peak period of gillnet fishing in LPB was between April and June while in LPO it was between September and November but shifted to January and April in 2018. It was noticed that the peak period of fishing in LPB was also altered to an unclear state in 2017 and 2018. For TCK, the peak period of fishing was from May to June (Annex 2). On average, the trend of the CPUE in this zone decreased slightly (Figure 3.12).

\section{(b) Zone 3: Mekong River from Vientiane to Nam Kam town}

There were six stations in Zone 3; two in Lao PDR (LBX, LVT) and four in Thailand (TKR, TSK, TNK, TUT). Figure 3.11b shows that TUT in Tha Uthen District, Nakhonphanom province had the highest catch rate with a range of 0.01 to $3 \mathrm{~kg} / 100 \mathrm{~m}^{2} /$ hour, while TKR in Khemarat District, Ubon Ratchathani province had the lowest catch rate ranging from 0.04 to $0.4 \mathrm{~kg} / 100 \mathrm{~m}^{2} /$ hour. Among these six stations, four (LBX, TKR, TSK and TNK) increased their catch rate during the survey period, while LVT and TUT decreased their catch rates. The mean CPUE of this zone indicated an increasing trend (Figure 3.12). The peak fishing period for each monitoring year was between May and July for LBX, between July and September for TUT and TKR, between September and November for LVT and TSK, and between October and December for TNK (Annex 2).

\section{(c) Zone 4: Mekong River from Nam Kam to Stung Treng (Se San/Se Kong confluences)}

In this zone, there were five stations; two in Cambodia (CST and CKT) in Stung Treng and Kratei provinces and three in Lao PDR (LSD, LCS and LSL) in Champasack province; however, the stations in Lao PDR could not be used for this report since there data were insufficient for the analysis. It was observed that both sites (CST and CKT) in Cambodia had similar catch rates ranging from 0.003 to $0.25 \mathrm{~kg} / 100 \mathrm{~m}^{2} /$ hour, but CKT showed an increasing trend (Figure $3.11 \mathrm{c}$ ), while CST showed a decreasing trend. In CST, a higher fish catch rate was observed at the end of the dry 
season in April and at the onset of the wet season between May and June of each monitoring year (Annex 2). However, the catch rate at CKT appeared to be high at the end of the wet season between September and November in each monitoring year. The mean CPUE of this zone showed a slight upward trend (Figure 3.12).

\section{(d) Zone 3S: Se Kong, Se San and Sre Pok rivers}

This Zone comprised three stations located in Cambodia (CSP, CSS, CSK) with one station each in the Se Kong, Se San and Sre Pok rivers. In relation to catch rate, CSP in Sre Pok River had almost double the catch rate $\left(0.01-0.65 \mathrm{~kg} / 100 \mathrm{~m}^{2} /\right.$ hour) compared to the two other stations (CSK and CSS). Based on the chart in Figure 3.11d, the catch rate at CSP was high between 2007 and 2009, but then it gradually dropped (Annex 2). On the contrary, at CSK the catch rate rose moderately from 2007 to 2018. For CSS, the catch rate appeared stable. The peak period for catch rates for the three stations was from June to December. The mean CPUE of this zone illustrated a slight downward trend (Figure 3.12).

\section{(e) Zone 7: Tonle Sap Great Lake}

There were six monitoring stations located in this zone: five in Tonle Sap Lake (CBT, CPS, CSR, CPT, $\mathrm{CKC}$ ) and one in Tonle Sap River (CKD). The stations in the lake were located in Battambang (CBT), Pursat (CPS), Siem Reap (CSR), Kompong Thom (CPT), and Kompong Chhang (CKC) provinces, while the river station was located in Kandal province (CKD). Among all stations, CKD had the highest catch rate ranging from 0.006 to $1.14 \mathrm{~kg} / 100 \mathrm{~m}^{2} /$ hour (Annex 2), yet with a slightly decreasing trend (Figure 3.11e). It can be observed that CBT, CPT, CPS and CSR had an increasing trend, while CKC and CKD had a decreasing trend. Unlike the other zones, the high catch rate of all stations in this zone was in the dry season between December and March (Figure 3.11e) when the reverse flow of Tonle Sap Lake back to the Mekong River via the Tonle Sap River occurs. The mean CPUE of this zone showed a steadily rising trend (Figure 3.12).

\section{(f) Zone 8: Vietnam Mekong Delta}

This zone covered all monitoring stations in Viet Nam, but only five stations were employed in this report due to data availability. Three stations (VAP, VCM, VTS) are located in An Giang province with the other two (VTV, VVL) at Tra Vinh and Vinh Long provinces, respectively. In regard to the catch rate, VTS and VTV had the highest with catch rates ranging from 0.1 to 1.6 $\mathrm{kg} / 100 \mathrm{~m}^{2} /$ hour (Annex 2), which was also the highest catch rate compared to all other stations in the LMB. Based on Figure 3.11f, the catch rate of VAP, VCM and VTV decreased while in the remaining stations it increased. It was observed that the peak period for the catch rate in this zone was in the dry season from February-May for each monitoring year (Annex 2). The mean CPUE of this zone indicated a decreasing trend (Figure 3.12). 

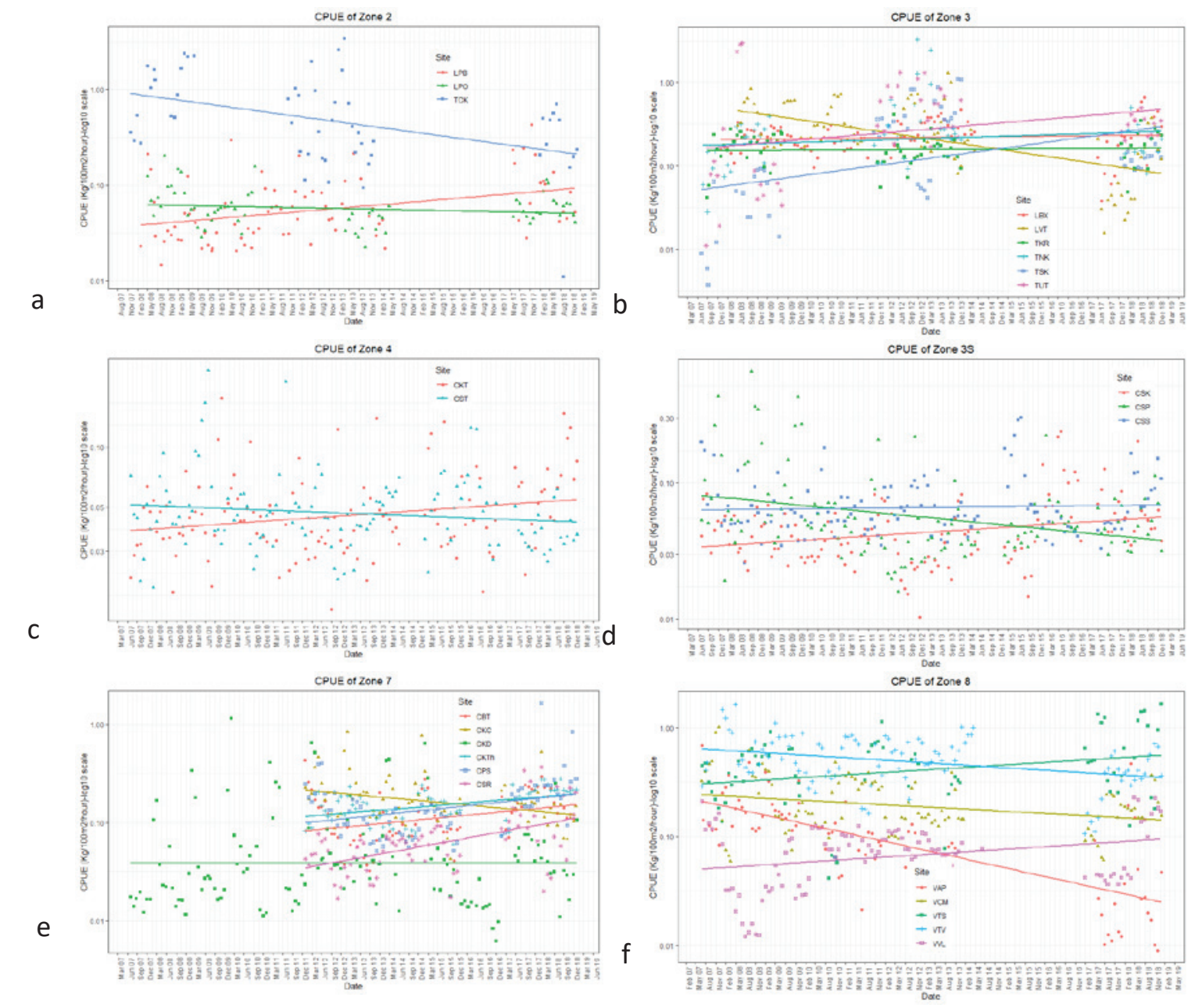

Figure 3.11 Catch per unit effort (CPUE) in $\log _{10}$ scale of gillnets for each station under BioRA zones, a: Zone2, b: Zone3, c: Zone4, d: Zone3S, e: Zone7 and f: Zone8

\section{Note:}

See Table 2.1 for details on each zone 


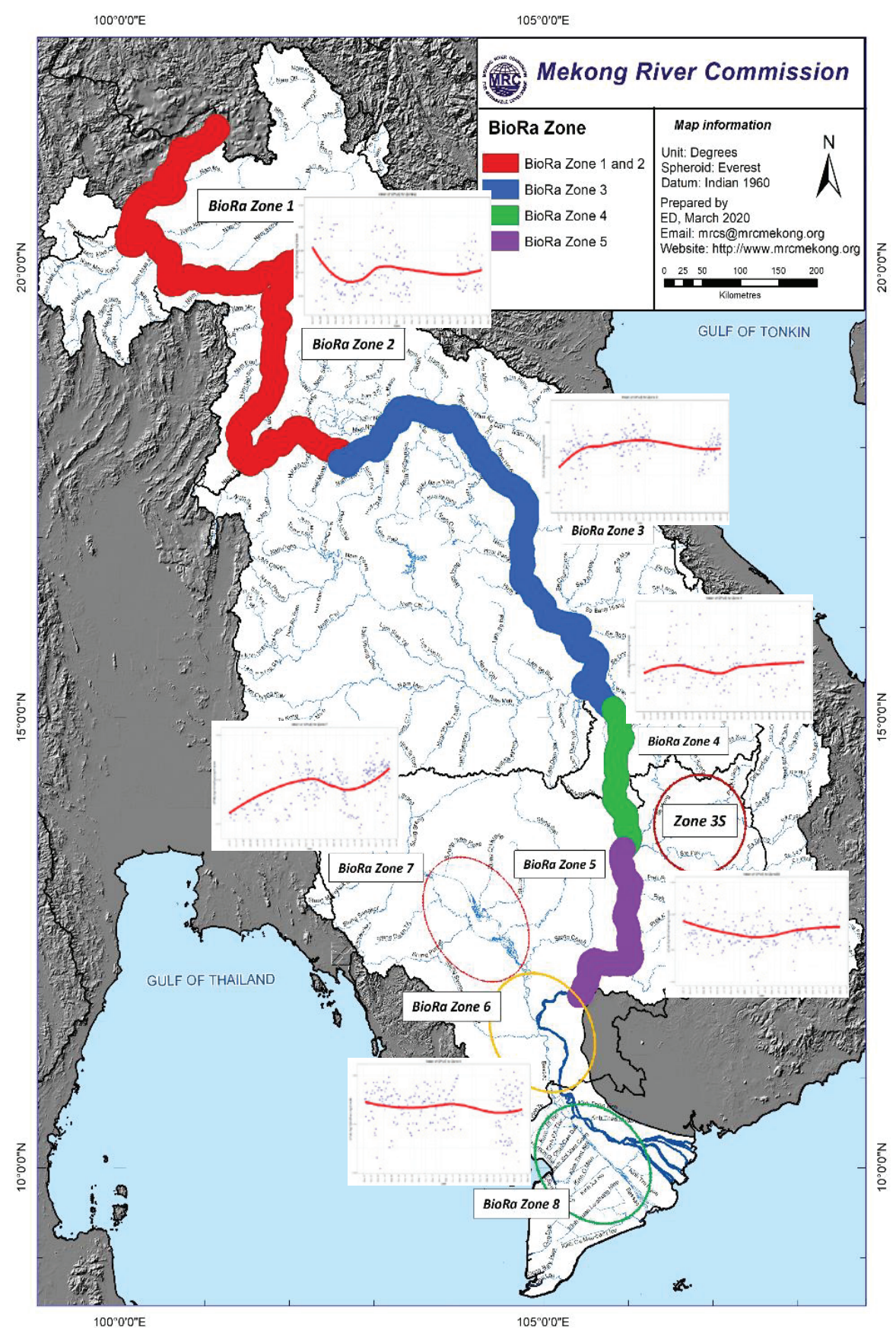

Figure 3.12 Mean catch per unit effort for each BioRa zone 


\subsection{SPATIAL AND TEMPORAL PATTERNS OF FISH ABUNDANCE AND DIVERSITY IN THE LMB}

\subsubsection{Spatial Patterns of fish richness and abundance}

\section{$L M B$ species richness}

Figure $\mathbf{3 . 1 3}$ shows the yearly cumulative fish species caught at each station clustered by BioRA zones during the monitoring period (2007-2018). Zone 3S, Zone 4 and Zone 7 had the highest richness in the LMB. At the station level, the highest richness was observed at CSK, CKT, CSS, and CPT, corresponding to the regional connectivity between 3S-Mekong with the Tonle Sap Lake, with more than 250 species caught each year at each station. The lowest richness stations were at the upper part of the Mekong River in Lao PDR and Thailand (i.e. LVT, TKR, LPB, LBX, TCK) and the delta of the LMB.

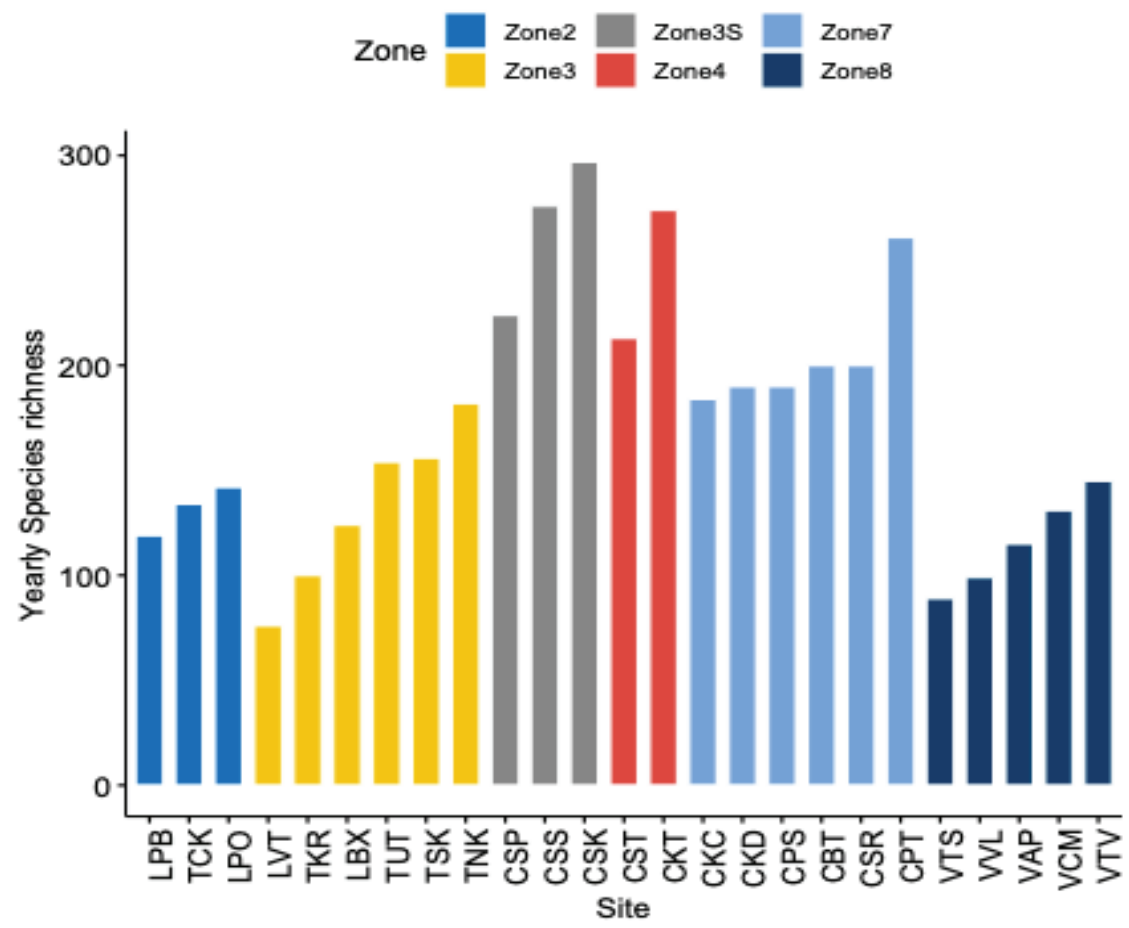

Figure 3.13 Cumulative annual fish species caught at each monitoring station, sorted for each BioRA zone 
The Annual Species Accumulation Curve (Figure 3.14) showed that the majority of stations did not reach asymptote, meaning that a number of additional species may be discovered with further sampling efforts. Only certain stations showed a species accumulation curve close to asymptote; for example, TNK, TCK, LPO, LBX, LPB, TKR and LVT located upstream of the LMB in Lao PDR and Thailand. Four stations - two in 3S (CSK and CSS), one in the upper part of Cambodia's Mekong River (CKT) and one in Tonle Sap Lake (CPT) - had the highest richness in the LMB. In contrast, the stations in the Viet Nam Mekong Delta (VTS and VVL), in Lao PDR (LVT) and in Thailand (TNK) had relatively low levels of richness.

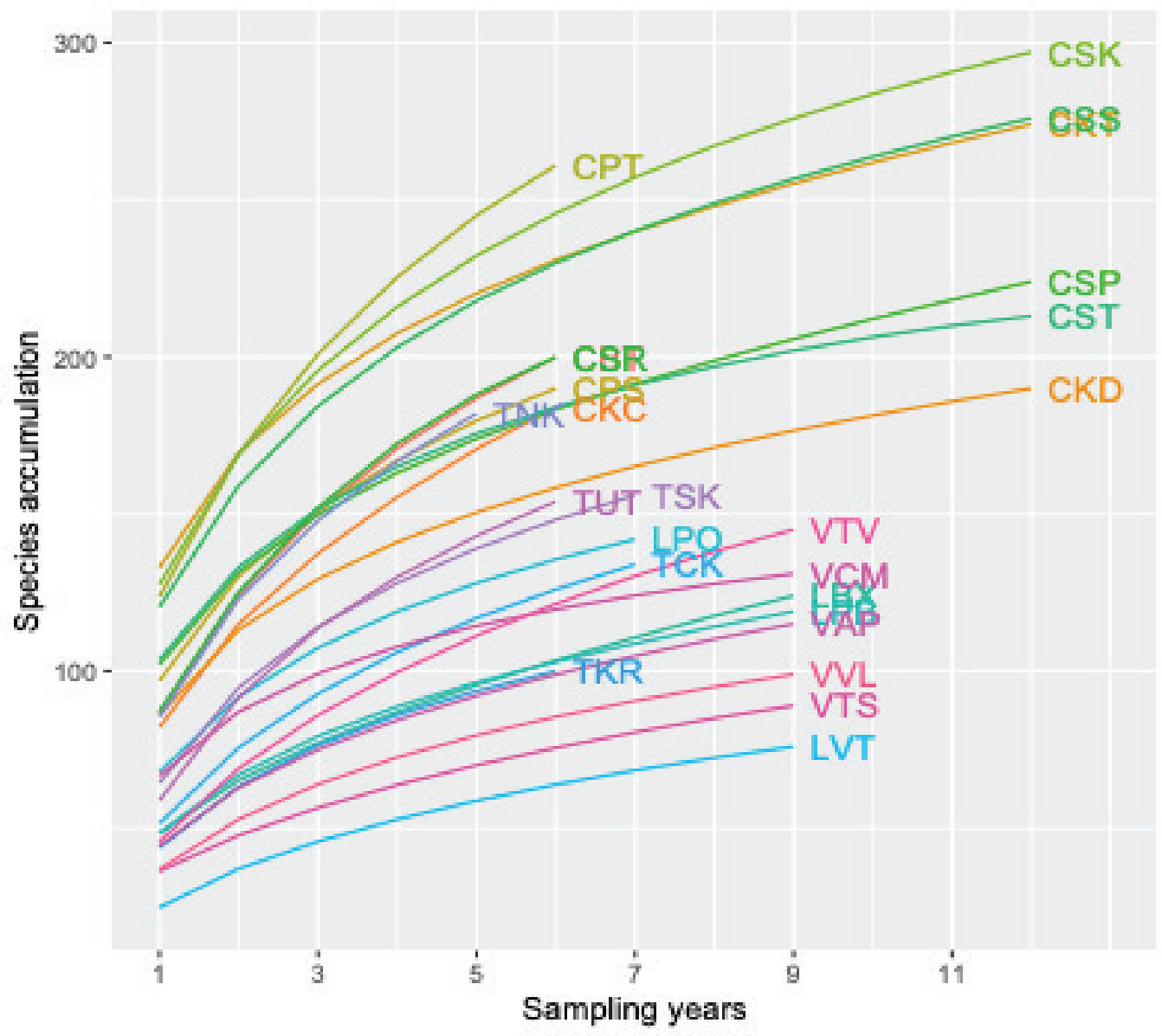

Figure 3.14 Annual species accumulation curves of the 25 FADM stations 


\section{Species richness and abundance by BioRA zones}

Figure 3.15 shows the average species richness at each BioRA zone of the LMB. It clearly shows that the highest richness was found in Zone 4 and Zone 3S with a range of richness from 50 to around 200 species, with an average of around 115 species. Zone 7 (Tonle Sap) also had high average species richness but with a large distribution from almost 40 to 200 species due to the flood-pulse ecosystem in this area. The upper part of the LMB (Zone 2 \& Zone 3 ) and the Mekong Delta (Zone 8) had lower richness and around 50 species on average.

The non-parametric ANOVA (Kruskal-Wallis test) showed a highly significant difference of richness among BioRA zones $(p<0.01)$. The pair-wise comparison using the Mann-Whitney test showed significant differences for all pairs, except between Zone 2 and Zone 3; between Zone 8 and Zone 2 and Zone 3; and between Zone 3S and Zone 4 (Table 3.1).

Table 3.1 Results of pair-wise comparison using the Mann-Whitney test showing the probability of pairs of richness between BioRA zones in the LMB

\begin{tabular}{llllll}
\hline & Zone 2 & Zone 3 & Zone 3S & Zone 4 & Zone 7 \\
\hline Zone 3 & 0.295 & - & - & - & - \\
\hline Zone 3S & $2.6 \mathrm{e}-09$ & $2.0 \mathrm{e}-10$ & - & - & - \\
\hline Zone 4 & $1.5 \mathrm{e}-07$ & $2.4 \mathrm{e}-08$ & 1.000 & - & - \\
\hline Zone 7 & $5.7 \mathrm{e}-06$ & $1.4 \mathrm{e}-07$ & 0.00045 & 0.00284 & - \\
\hline Zone 8 & 0.052 & 1.000 & $3.1 \mathrm{e}-13$ & $2.5 \mathrm{e}-10$ & $2.4 \mathrm{e}-11$ \\
\hline
\end{tabular}

Note:

The $p$-values lower than 0.05 mean significant differences between the pairs of zones 


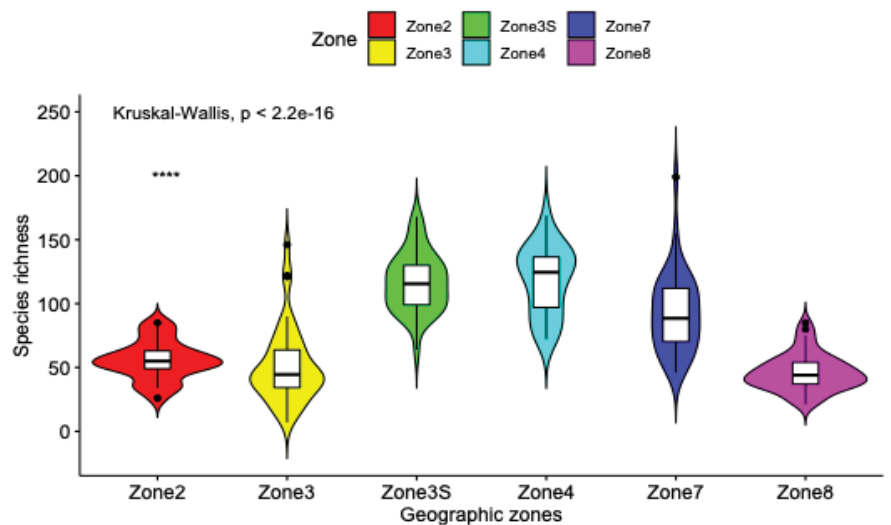

Figure 3.15 Violin plot and boxplot showing the distribution of Species Richness (SR) for different BioRA zones in the LMB

Note:

The non-parametric ANOVA (Kruskal-Wallis) test gave highly significant $p$-values $(<0.01)$ for the differences in richness between zones

The highest relative fish abundance in the LMB was detected in Zone7 (Tonle Sap), followed by the Mekong delta (Zone 8). The other zones had quite similar and constant fish abundance over the monitoring period, except for Zone 3, which had a relatively large range of abundance (Figure 3.16).

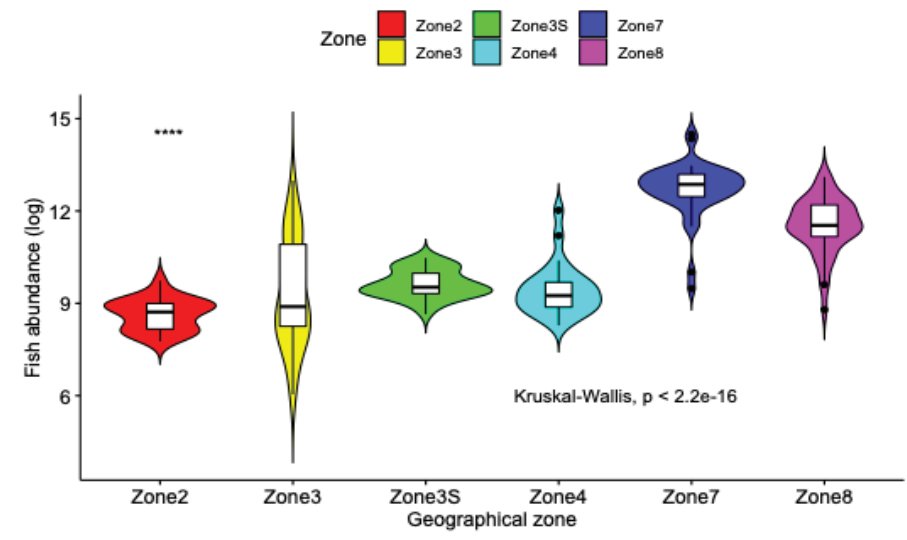

Figure 3.16 Violin plot and boxplot of fish abundance (log) for different BioRA zones of the LMB

Note:

The non-parametric ANOVA (Kruskal-Wallis) test gave highly significant $p$-values $(<0.01)$ for the differences in richness between zones 
The non-parametric ANOVA test (Kruskal-Wallis) showed an overall significant difference of relative fish abundance between LMB zones $(p<0.001)$. The pair-wise comparison using the Mann-Whitney test showed a significant difference for all pairs, except for Zone 2 and Zone 3. Zone 3 was not significantly different from Zones $3 S$ and 4 as well as Zones 4 and $3 S$ (Table 3.2).

Table 3.2 Results of pair-wise comparison using the Mann-Whitney test showing the probability of pairs of fish abundance difference between BioRA zones in the LMB

\begin{tabular}{llllll}
\hline & Zone2 & Zone3 & Zone3S & Zone4 & Zone7 \\
\hline Zone3 & 0.383 & - & - & - & - \\
\hline Zone3S & $2.3 \mathrm{e}-09$ & 0.2515 & - & - & - \\
\hline Zone4 & 0.0012 & 0.3833 & 0.2482 & - & - \\
\hline Zone7 & $2.5 \mathrm{e}-16$ & $6.2 \mathrm{e}-16$ & $<2 \mathrm{e}-16$ & $3.9 \mathrm{e}-14$ & - \\
\hline Zone8 & $1.0 \mathrm{e}-14$ & $7.0 \mathrm{e}-09$ & $5.5 \mathrm{e}-15$ & $1.8 \mathrm{e}-10$ & $1.4 \mathrm{e}-09$ \\
\hline
\end{tabular}

Note:

The p-values lower than 0.05 mean significant differences between the pair of zones

\section{Relationship between species richness and abundance in the $L M B$}

The scatterplot between species richness and fish abundance for each zone is presented in Figure 3.17. The ellipse shows the one standard deviation confidence limit for each zone. It can be seen clearly that Zone 7 has the highest richness and abundance. A strong overlap between Zone 4 and Zone $3 S$ indicates their similarity of high richness, but with a lower abundance than Zone 7. Zone 2 had the lowest richness and abundance, whereas Zone 8 had high abundance with a similar richness as Zone 2. Zone 3 also had low richness and abundance, but high variability since the ellipsoid overlaps with several other zones. Finally, Zone 7 had the highest richness and abundance in the LMB. 


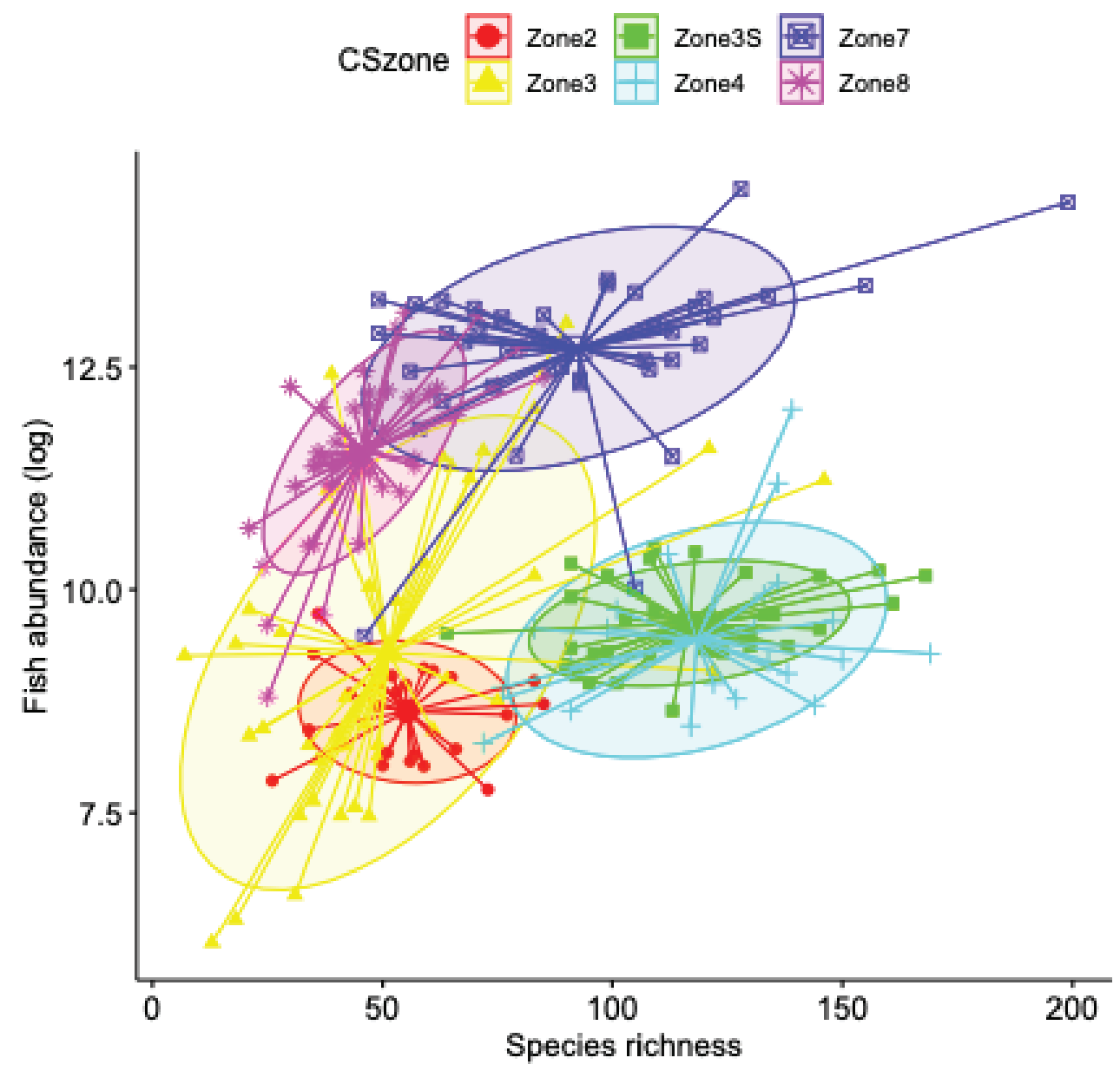

Figure 3.17 Scatterplot of the relationship between species richness and fish abundance (log) pooled by BioRA zones

Note:

The size of the ellipse relates to the 1-SD confidence of samples in each zone according to their values of fish richness and abundance (log-scale)

\subsubsection{Temporal patterns of fish species richness and abundance in the LMB}

Yearly species richness was plotted against the time period to show the trend of temporal changes by fitting with the linear model for each BioRA zone. It can be seen clearly that Zone 4 and Zone 8 decreased in richness over time, but in Zone 2, Zone 3 and Zone 7 richness increased slightly. The richness of Zone $3 \mathrm{~S}$ appeared to be stable during the survey period (Figure 3.18). 


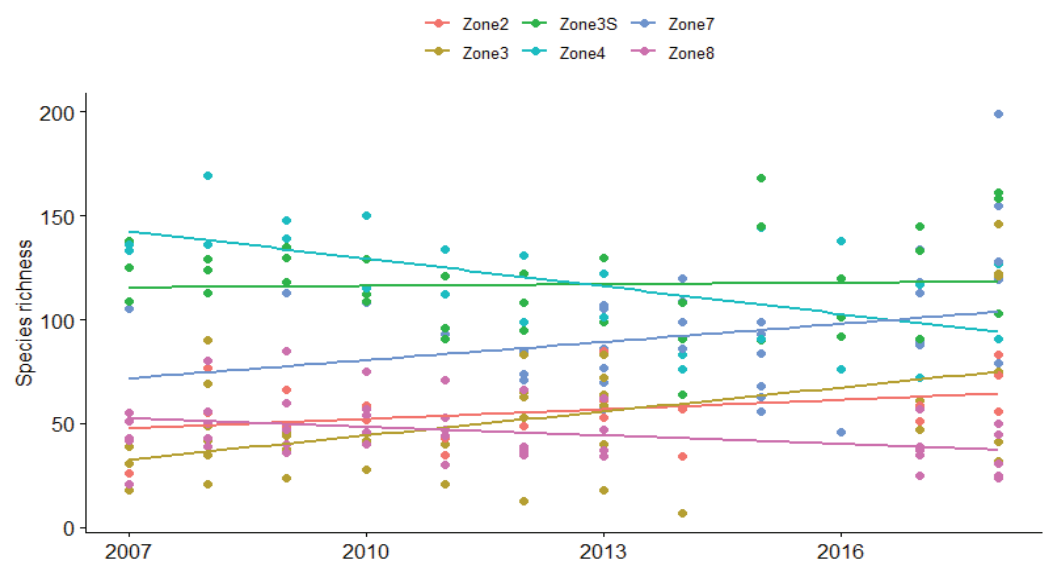

Figure 3.18 Scatterplot of monthly species richness from 2007 to 2018, fitted by linear models for each BioRA zone

The temporal trend of relative fish abundance caught in the LMB showed different results compared to species richness. In fact, only Zone 7 (Tonle Sap Lake) saw an increase in relative abundance during the survey period, while Zone 2, Zone 4 and Zone 8 decreased in relative abundance. The remaining zones had a stable trend during the same period (Figure 3.19).

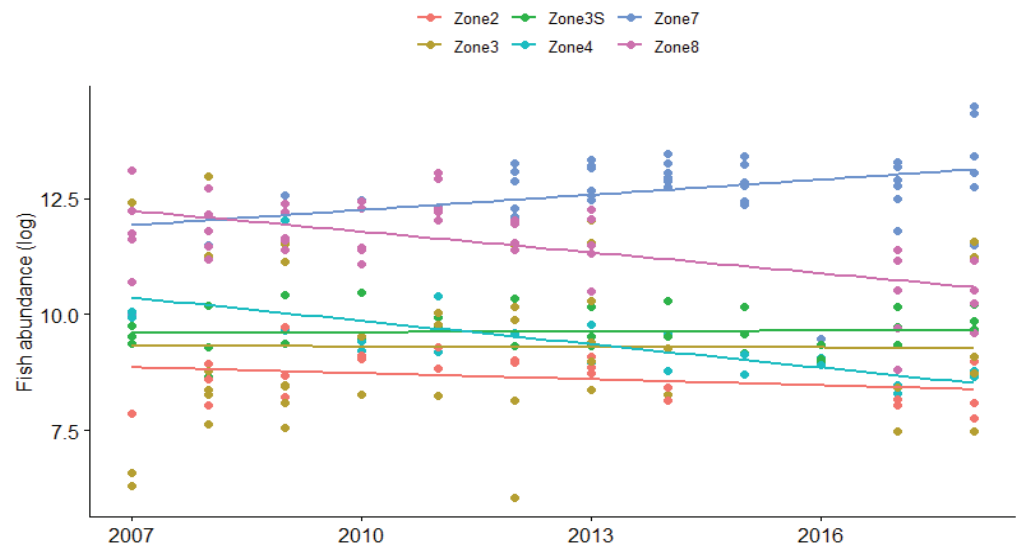

Figure 3.19 Scatterplot of monthly fish abundance (in log transform) from 2007 to 2018, fitted by linear models for each BioRA zone 


\section{Spatial and temporal patterns of fish species diversity}

The diversity of a fish community needs (in most instances) to take into account both species richness and the abundance with which individuals are distributed among species.

There are two major forms of these indices: dominance indices and information indices. While more than 60 indices have been described, the three most widely used in the ecological literature have been considered for this study: Simpson's, Shannon-Weiner, and Equitability (or Evenness).

The Simpson's Index (D) is considered as a dominance index because it weights towards the abundance of the most common species. For this reason, in this report the ratio 1/D was used, known as the Inverse-Simpson index where a high value reveals high diversity.

The Shannon-Weiner Index (sh) (also incorrectly known as Shannon-Weaver) belongs to a subset of indices that maintain that diversity can be measured much like the information contained in each species. The function was originally to determine the amount of information in a code or signal and is defined as the proportion of individuals in the $\mathrm{i}^{\text {th }}$ species using the natural logarithm.

The Equitability or Evenness Index (E) is a measure of biodiversity that quantifies how equal the community is numerically. The value is constrained between 0 and 1.0 with 1 assuming that all species are represented within the sample site. The Evenness values close to 0 testify the disequilibrium in an ecosystem with 1 or 2 dominant species in the sample.

In the LMB (Figure 3.20), Zone 35 has the highest diversity according to the Simpson Index (D) and Shannon Index (sh). Furthermore, both indices show that Zone 8 in the Mekong Delta had the lowest diversity in the LMB. The high values of the Evenness Index (median values $>0.5$ for all zones) reveal that all species are well represented in all BioRA zones. 


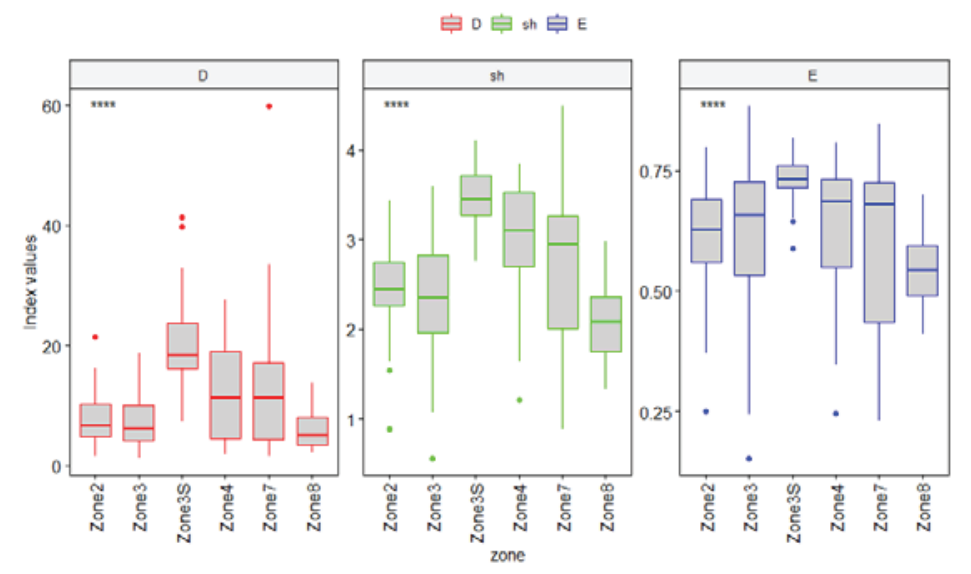

Figure 3.20 Diversity indices of fish in each BioRA zone: The inverse Simpson Index (D), the Shannon-Wiener Index (sh) and the Evenness Index (E)

Note:

Stars in the top-left corner show the significant level of difference (kruskal-Wallis test)

Temporally, over the past 12 years of the FADM period in the LMB, some temporal variations for the diversity indices - Simpson, Shannon and Evenness (Figure 3.21) - with significant differences were revealed by the non-parametric ANOVA (Kruskal-Wallis test, $p<0.5$ ). The high Evenness index of around 0.7 during the FADM survey period testify that the LMB is a mature equilibrium system without dominant species. The high values of the Inverse Simpson index (between 10 and 20) and the Shannon diversity index (globally 2.5 to 3 ) indicate the high diversity of the LMB. All 3 indices have slightly increased during recent years probably due to increased fishing effort during these last 5 years. 


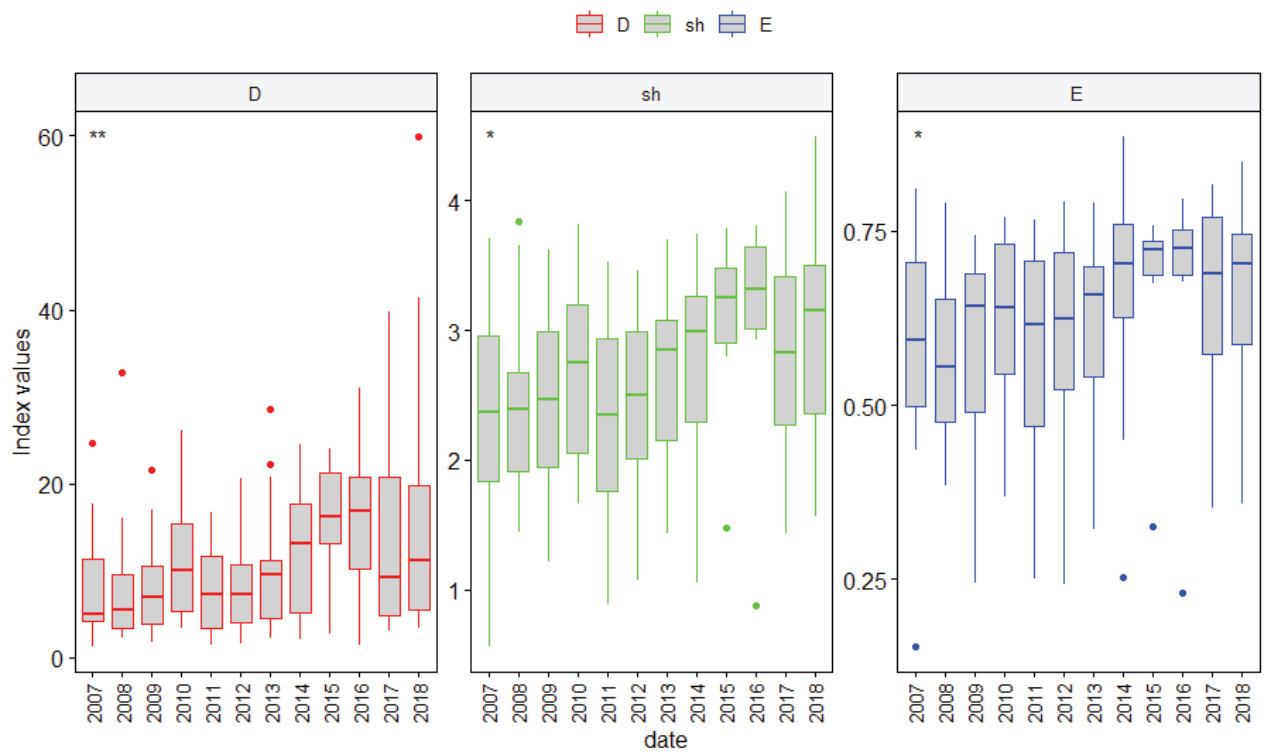

Figure 3.21 Diversity indices of fish in the LMB from 2007 to 2018: The inverse Simpson index (D), the Shannon-Wiener index (sh) and the Evenness index (E)

Note:

Stars in the top-left corner show the significant level of difference

\section{Spatio-temporal patterns of beta diversity in the LMB}

To identify the spatio-temporal changes of the fish community, Local Contribution for Beta Diversity (LCBD) was used. In the LMB, the yearly data from the FADM stations with the $\mathrm{SS}_{\text {total }}$ of 167.01 and the $B D_{\text {total }}$ of 0.7357 showed that species substitution is quite high. Figure 3.22 shows the distribution of LCBD values for each station. The two stations in the Mekong Delta (VVL and VTV) had the highest LCBD values, meaning that a high turnover of species occurred in these stations during the FADM period. Several stations in the upstream part of Thailand and Lao PDR also had high LCBD values. Stations in Tonle Sap Lake and 3S areas had the lowest LCBD values, meaning that fish species' compositions were quite stable during the FADM period. 

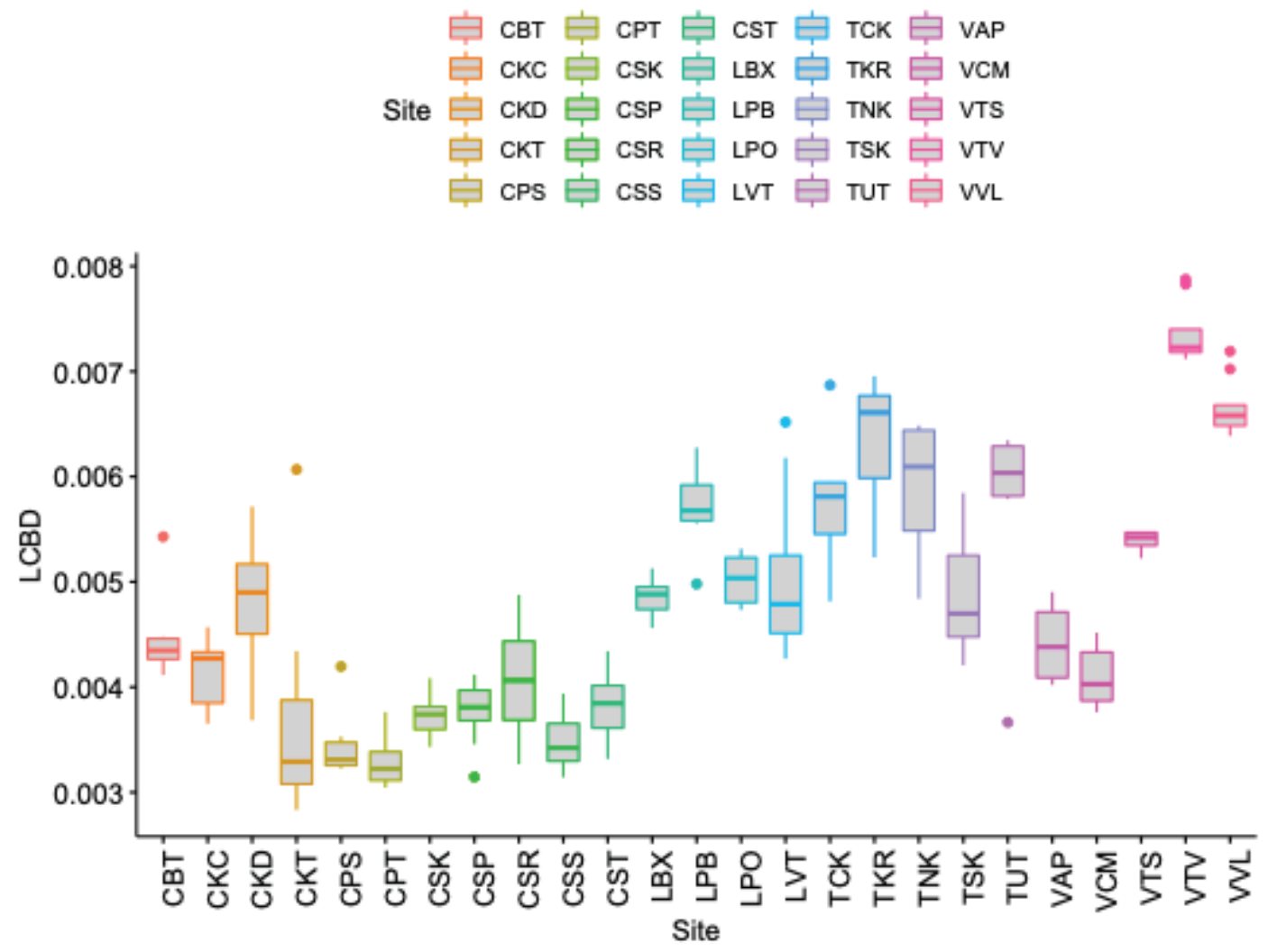

Figure 3.22 Distribution of LCBD in the FADM stations

Note:

Low values mean stable fish communities from one year to the next; high values mean a high turnover of fish species in the community

The Species Contribution for Beta Diversity (SCBD) showed that among 571 species recorded in the $\mathrm{LMB}$, only a few species contributed greatly to the changes in beta diversity. The first group of five species (Henicorhynchus lobatus, H.siamensis, Anabas testudineus, Sikukia gudgeri, and Coilia lindmani) with SCBD higher than 0.03 (Figure 3.23) contribute strongly to the changes in beta diversity in the LMB. Among these five species, only one was a black fish (Anabas testudineus) with the rest white fish. The second group of six other species with SCBD values between 0.02 and 0.03 (Pangasius macronema, Mystus mysticetus, Pangasius conchophilus, Hypsibarbus malcolmi, Puntioplites falcifer, Trichogaster trichopterus) are also very important to the changes in LCBD values, but less so than the first group. 


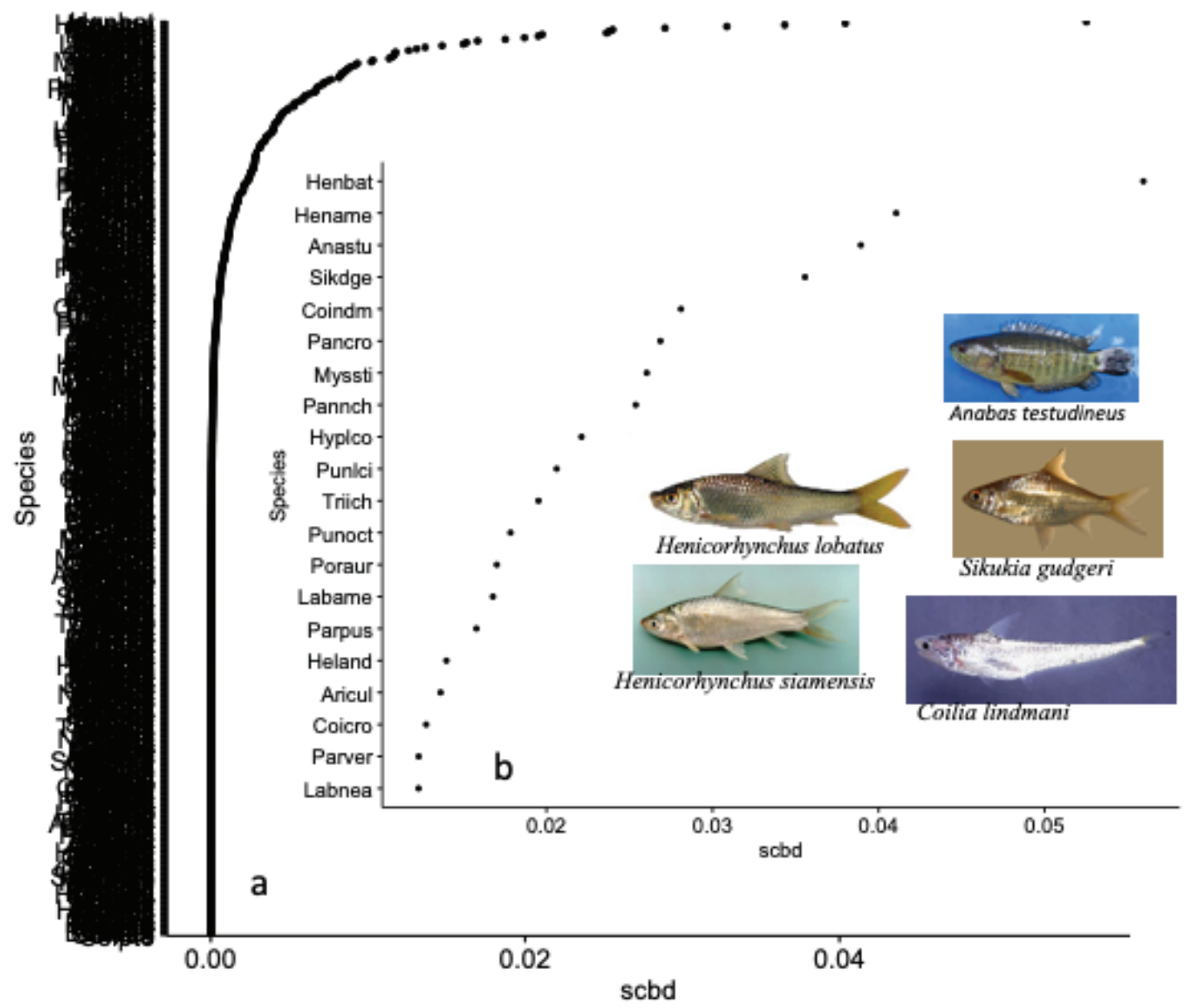

Figure 3.23 Species Contribution to Beta Diversity (SCBD) in the LMB

Note:

The profile of all 571 species in the LMB, zooming in on 20 species with SCBD $>0.01$ and detail of the 5 highest SCBD values

\subsection{FISH COMMUNITY PATTERNS AND THEIR RELATIONSHIP WITH ENVIRONMENTAL FACTORS}

\subsubsection{Patterns of fish communities in the Lower Mekong River (LMR)}

The FADM from 25 monitoring stations recorded 571 fish species from 2007 to 2018, yet rare species occupied a larger proportion of fish species. To avoid noise in the analysis and to ensure 
better graphic visualisation, species with less than 5\% occurrence during the 2007-2018 period were removed from the fish assemblage study. This means only 247 species and over 228 yearlysite samples were selected for this study.

Hierarchical clustering using the Brey-Curtis Dissymmetric Distance and Ward Agglomerative Methods were used to construct a dendrogram. According to the dendrogram structure in Figure 3.24, four main groups are defined. Table 3.3 summarizes the correspondence between clustering groups and BioRA zones. It clearly shows that the majority of samples from Zone 2 and Zone 3 belonged to Cluster 1 giving evidence of similar fish composition for samples from these zones. Similarly, most samples from Zone $3 \mathrm{~S}$ and Zone 4 were grouped under Cluster 3 . For Zone 7 (Tonle Sap), almost all the samples belonged to Cluster 2, while almost half of Zone 8 belonged to Cluster 2 with the other half under Cluster 4 . This is probably because CKD was assigned to Zone 8 instead of Zone 7.

Cluster Dendrogram

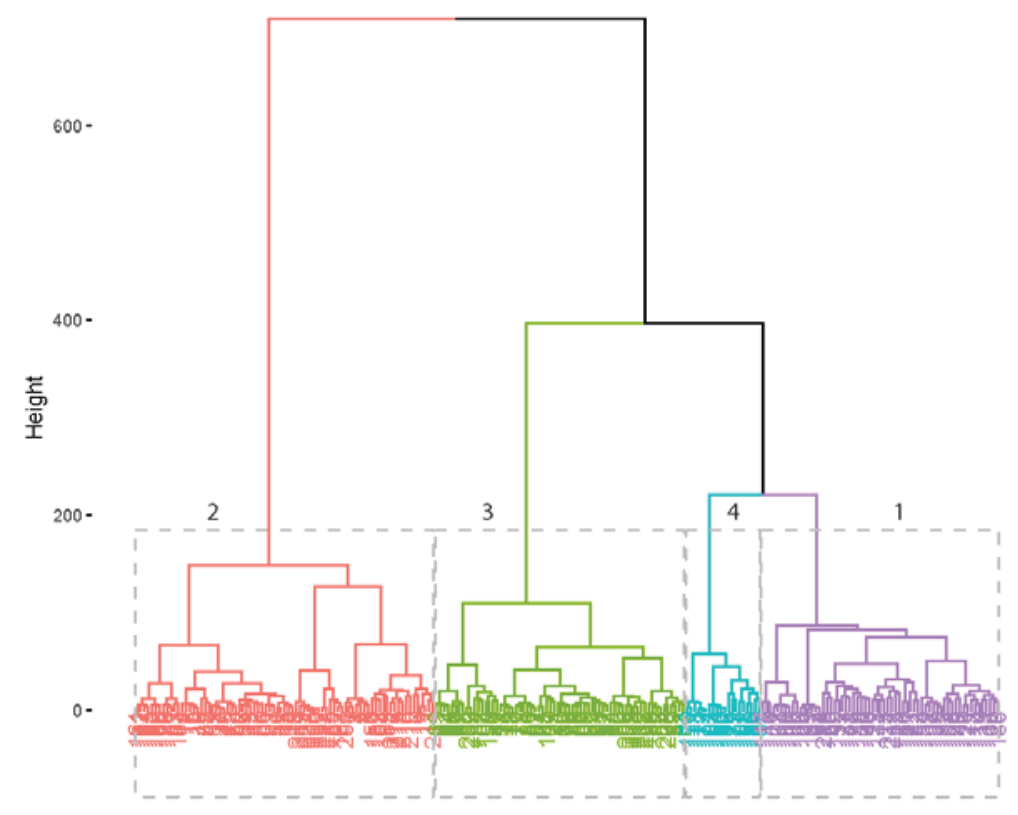

Figure 3.24 Dendrogram of hierarchical clustering of yearly site fish species in the LMB showing the 4 clusters of samples according to the degree of dissimilarity 
Table 3.3 Correspondence between BioRA zones of the LMB and results of hierarchical clustering based on yearly fish composition in the LMB during the FADM survey period

\begin{tabular}{lllll}
\hline BioRA Zones & \multicolumn{4}{l}{ Hierarchical Clustering Class } \\
\cline { 2 - 5 } & $\mathbf{1}$ & $\mathbf{2}$ & $\mathbf{3}$ & $\mathbf{4}$ \\
\hline Zone2 & 23 & 0 & 0 & 0 \\
\hline Zone3 & 34 & 11 & 3 & 0 \\
\hline Zone35 & 0 & 0 & 36 & 0 \\
\hline Zone4 & 1 & 1 & 22 & 0 \\
\hline Zone7 & 2 & 42 & 3 & 0 \\
\hline Zone8 & 3 & 25 & 2 & 20 \\
\hline
\end{tabular}

The indicator species under each group were identified using the "multipatt" function from the "indicspecies" package in R (De Cáceres et al., 2010; De Cáceres \& Legendre, 2009; Dufrêne \& Legendre, 1997). Group 1, with a total of 63 samples, included samples mostly from Thailand and Lao PDR in the upstream of the LMB, but also a few samples from Cambodia and Vietnam. The Indicator Species value (IndVal) gave six indicator species of this group categorized into three guilds: grey fish (G4), black fish (G6), and estuarine resident (G7) (Table 3.4).

Group 2 accounted for 79 samples: 42 from the Tonle Sap area and the rest from Thailand and Vietnam (Annex 5). Fourteen (14) fish species were indicative of this group (Table 3.4) and those species were categorized into five guilds including: rhithron resident (G1), long-distance white fish (G2); short-distance white fish (G3); grey fish (G4); and exotic species (G11). Among these five guilds, G3 was the dominant guild (six species) followed by G11 (four species).

Group 3 consisted of 66 samples, of which 36 were from Zone 3S, and 22 samples from Kratie and Stung Treng (in the upper part of the Cambodia Mekong River). The rest were from the middle part of Lao PDR and Thailand, and the Vietnam Mekong Delta (Annex 5). This group had the largest number of indicator species with 57 species (Table 3.4) classified into eight guilds. The dominant guilds were the short-distance white fish (G3) and grey fish (G4) containing 16 and 15 species, respectively.

Finally, group 4 was the smallest with only 20 samples. All samples were mainly taken from VTV and VVL in the Mekong Delta. Nineteen fish species were ecologically characterized in this group (Table 3.4) and classified into five guilds, including a long-distance white fish (G2), estuarine resident (G7), anadromous fish (G8), marine visitor (G10), and exotic species (G11). The dominant guild was $\mathrm{G} 7$ (ten species) followed by G10 (five species). 
Table $\mathbf{3 . 4}$ Indicator species with indicative statistical values andassociated probability See sample membership of each group in Annex $\mathbf{5}$

\begin{tabular}{|c|c|c|c|c|c|c|c|c|}
\hline Group & Order & Family & Scientific Name & Short Name & $\begin{array}{l}\text { Statistical } \\
\text { Value }\end{array}$ & P.value & Guild & $\begin{array}{l}\text { IUCN } \\
\text { Category }\end{array}$ \\
\hline \multirow[t]{6}{*}{1} & Tetraodontiformes & Tetraodontidae & Monotrete leiurus & Moniur & 0.348 & $0.017 *$ & G7 & NA \\
\hline & Siluriformes & Bagridae & Mystus mysticetus & Myssti & 0.88 & $0.001 * * *$ & G4 & LC \\
\hline & Siluriformes & Siluridae & Ompok hypophthalmus & Omppop & 0.494 & $0.002 * *$ & G4 & NA \\
\hline & Cypriniformes & Cyprinidae & Parachela maculicauda & Parcul & 0.458 & $0.001 * * *$ & G4 & LC \\
\hline & Cypriniformes & Cyprinidae & Puntius brevis & Punevi & 0.578 & $0.001 * * *$ & G6 & LC \\
\hline & Perciformes & Osphronemidae & Trichogaster pectoralis & Tricto & 0.587 & $0.001 * * *$ & G6 & LC \\
\hline \multirow[t]{14}{*}{2} & Siluriformes & Sisoridae & Bagarius & Baggar & 0.808 & $0.001 * * *$ & G1 & $N T$ \\
\hline & Siluriformes & Siluridae & Belodontichthys dinema & Belnem & 0.707 & $0.001 * * *$ & G11 & $N A$ \\
\hline & Cypriniformes & Cyprinidae & Cirrhinus prosemion & Cirose & 0.354 & $0.015 *$ & G3 & NA \\
\hline & Cypriniformes & Cyprinidae & Cirrhinus cirrhosis & Cirrrh & 0.467 & $0.018 *$ & G11 & NA \\
\hline & Cypriniformes & Cyprinidae & Cyprinus carpio & Cyprpi & 0.814 & $0.001 * * *$ & G11 & NA \\
\hline & Siluriformes & Pangasiidae & $\begin{array}{l}\text { Helicophagus } \\
\text { leptorhynchus }\end{array}$ & Helpto & 0.493 & $0.001 * * *$ & G3 & $D D$ \\
\hline & Siluriformes & Bagridae & Hemibagrus nemurus & Hemmur & 0.466 & $0.003 * *$ & G3 & $L C$ \\
\hline & Cypriniformes & Cyprinidae & Hypsibarbus vernayi & Hyprna & 0.531 & $0.001 * * *$ & G3 & $L C$ \\
\hline & Siluriformes & Siluridae & Kryptopterus limpok & Krympo & 0.331 & $0.023 *$ & G3 & $N A$ \\
\hline & Cypriniformes & Cyprinidae & Labeo erythropterus & Labyth & 0.567 & $0.001 * * *$ & G11 & NA \\
\hline & Siluriformes & Bagridae & Mystus nemurus & Mysmur & 0.623 & $0.001 * * *$ & G3 & $N A$ \\
\hline & Siluriformes & Pangasiidae & Pangasianodon gigas & Pangas & 0.453 & $0.006 * *$ & G2 & $C R$ \\
\hline & Cypriniformes & Cyprinidae & Poropuntius deauratus & Poraur & 0.555 & $0.001 * * *$ & G1 & $E N$ \\
\hline & Cypriniformes & Cyprinidae & Sikukia gudgeri & Sikdge & 0.679 & $0.001 * * *$ & G4 & $D D$ \\
\hline \multirow[t]{2}{*}{3} & Cypriniformes & Cobitidae & Acanthopsis sp.1 & Aca.1 & 0.389 & $0.044 *$ & G3 & $N A$ \\
\hline & Cypriniformes & Cobitidae & Acanthopsis sp. 5 & Aca. 5 & 0.386 & $0.013 *$ & G3 & NA \\
\hline
\end{tabular}




\begin{tabular}{|c|c|c|c|c|c|c|c|c|}
\hline Group & Order & Family & Scientific Name & Short Name & $\begin{array}{l}\text { Statistical } \\
\text { Value }\end{array}$ & P.value & Guild & $\begin{array}{l}\text { IUCN } \\
\text { Category }\end{array}$ \\
\hline & Pleuronectiformes & Soleidae & $\begin{array}{l}\text { Achiroides } \\
\text { melanorhynchus }\end{array}$ & Achlan & 0.536 & $0.001 * * *$ & G7 & $N A$ \\
\hline & Siluriformes & Sisoridae & Bagarius suchus & Bagchu & 0.834 & $0.001 * * *$ & G1 & $N T$ \\
\hline & Siluriformes & Bagridae & Bagrichthys macracanthus & Bagcra & 0.922 & $0.001 * * *$ & G3 & $N A$ \\
\hline & Siluriformes & Bagridae & Bagrichthys obscurus & Bagscu & 0.915 & $0.001 * * *$ & G3 & $L C$ \\
\hline & Cypriniformes & Cyprinidae & $\begin{array}{l}\text { Barbonymus } \\
\text { schwanenfeldii }\end{array}$ & Barhwa & 0.874 & $0.001 * * *$ & G4 & $L C$ \\
\hline & Siluriformes & Siluridae & Belodontichthys truncatus & Belunc & 0.76 & $0.001 * * *$ & G3 & $L C$ \\
\hline & Siluriformes & Siluridae & Botia sp. c.f. lecontei & Botcont & 0.43 & $0.005 * *$ & G3 & $N A$ \\
\hline & Perciformes & Channidae & Channa grandinosa & Chaand & 0.341 & $0.029 *$ & G6 & $N A$ \\
\hline & Perciformes & Channidae & Channa marulioides & Charul & 0.619 & $0.001 * * *$ & G6 & $N A$ \\
\hline & Osteoglossiformes & Notopteridae & Chitala blanci & Chianc & 0.88 & $0.001 * * *$ & G1 & NT \\
\hline & Osteoglossiformes & Notopteridae & Chitala lopis & Chipis & 0.654 & $0.001 * * *$ & G3 & $L C$ \\
\hline & Cypriniformes & Cyprinidae & Cirrhinus jullieni & Cirlli & 0.885 & $0.001 * * *$ & G3 & $D D$ \\
\hline & Siluriformes & Clariidae & Clarias meladerma & Clalad & 0.472 & $0.002 * *$ & G6 & $N A$ \\
\hline & Cypriniformes & Cyprinidae & Crossocheilus reticulatus & Crotic & 0.409 & $0.009 * *$ & G5 & $L C$ \\
\hline & Cypriniformes & Cyprinidae & Cyclocheilichthys lagleri & Cycgle & 0.846 & $0.001 * * *$ & G4 & $L C$ \\
\hline & Cypriniformes & Cyprinidae & Cyclocheilichthys apogon & Cycogo & 0.771 & $0.001 * * *$ & G4 & $L C$ \\
\hline & Cypriniformes & Cyprinidae & Cyclocheilichthys tapiensis & Cycpie & 0.754 & $0.001 * * *$ & G4 & $N A$ \\
\hline
\end{tabular}




\begin{tabular}{|c|c|c|c|c|c|c|c|c|}
\hline Group & Order & Family & Scientific Name & Short Name & $\begin{array}{l}\text { Statistical } \\
\text { Value }\end{array}$ & P.value & Guild & $\begin{array}{l}\text { IUCN } \\
\text { Category }\end{array}$ \\
\hline & Cypriniformes & Cyprinidae & Discherodontus ashmeadi & Dishme & 0.48 & $0.005 * *$ & G1 & $L C$ \\
\hline & Cypriniformes & Cyprinidae & Hampala dispar & Hamspa & 0.849 & $0.001 * * *$ & G5 & $L C$ \\
\hline & Siluriformes & Bagridae & Hemibagrus sp. & Hemisp & 0.353 & $0.011 *$ & G3 & $N A$ \\
\hline & Cypriniformes & Cyprinidae & $\begin{array}{l}\text { Henicorhynchus } \\
\text { ornatipinnis }\end{array}$ & Hennat & 0.368 & $0.020 *$ & G5 & $N A$ \\
\hline & Siluriformes & Heteropneustidae & $\begin{array}{l}\text { Heteropneustes } \\
\text { kemratensis }\end{array}$ & Hetmra & 0.377 & $0.010 * *$ & G6 & $N A$ \\
\hline & Cypriniformes & Cyprinidae & Hypsibarbus pierrei & Hyperr & 0.925 & $0.001 * * *$ & G3 & $D D$ \\
\hline & Cypriniformes & Cyprinidae & Hypsibarbus suvattii & Hypvat & 0.913 & $0.001 * * *$ & G3 & $N A$ \\
\hline & Siluriformes & Siluridae & Kryptopterus bicirrhis & Krycir & 0.433 & $0.003 * *$ & G3 & $L C$ \\
\hline & Siluriformes & Siluridae & Kryptopterus cryptopterus & Kryypt & 0.632 & $0.001 * * *$ & G3 & NA \\
\hline & Cypriniformes & Cyprinidae & Labeo dyocheilus & Laboch & 0.706 & $0.001 * * *$ & G11 & $L C$ \\
\hline & Cypriniformes & Cyprinidae & Lobocheilos melanotaenia & Loblan & 0.698 & $0.001 * * *$ & G1 & $L C$ \\
\hline & Cypriniformes & Cyprinidae & Luciosoma bleekeri & Luceek & 0.786 & $0.001 * * *$ & G3 & $L C$ \\
\hline & Synbranchiformes & Mastacembelidae & $\begin{array}{l}\text { Macrognathus } \\
\text { taeniagaster }\end{array}$ & Maceni & 0.478 & $0.002 * *$ & G6 & $N A$ \\
\hline & Synbranchiformes & Mastacembelidae & $\begin{array}{l}\text { Macrognathus } \\
\text { semiocellatus }\end{array}$ & Macmio & 0.469 & $0.003 * *$ & G6 & $L C$ \\
\hline & Cypriniformes & Cobitidae & $\begin{array}{l}\text { Misgurnus } \\
\text { anguillicaudatus }\end{array}$ & Misgui & 0.413 & $0.003 * *$ & G11 & $N A$ \\
\hline & Tetraodontiformes & Tetraodontidae & Monotrete cambodgiensis & Monmbo & 0.359 & $0.020 *$ & G4 & $L C$ \\
\hline & Tetraodontiformes & Tetraodontidae & Monotrete barbatus & Monrba & 0.589 & $0.001 * * *$ & G7 & $N A$ \\
\hline
\end{tabular}




\begin{tabular}{|c|c|c|c|c|c|c|c|c|}
\hline Group & Order & Family & Scientific Name & Short Name & $\begin{array}{l}\text { Statistical } \\
\text { Value }\end{array}$ & P.value & Guild & $\begin{array}{l}\text { IUCN } \\
\text { Category }\end{array}$ \\
\hline & Siluriformes & Bagridae & Mystus wolffii & Myslff & 0.631 & $0.001 * * *$ & G4 & $N A$ \\
\hline & Siluriformes & Bagridae & Mystus gulio & Myslio & 0.483 & $0.002 * *$ & G4 & $L C$ \\
\hline & Siluriformes & Bagridae & Mystus multiradiatus & Myslti & 0.58 & $0.001 * * *$ & G4 & $L C$ \\
\hline & Cypriniformes & Cyprinidae & Onychostoma gerlachi & Onyrla & 0.423 & $0.002 * *$ & G1 & $N A$ \\
\hline & Cypriniformes & Cyprinidae & Onychostoma fusiforme & Onysif & 0.439 & $0.002 * *$ & G1 & $L C$ \\
\hline & Perciformes & Osphronemidae & Osphronemus exodon & Ospodo & 0.583 & $0.003 * *$ & G1 & VU \\
\hline & Perciformes & Osphronemidae & Osphronemus goramy & Ospram & 0.921 & $0.001 * * *$ & G1 & $L C$ \\
\hline & Cypriniformes & Cyprinidae & Osteochilus waandersii & Ostand & 0.577 & $0.001 * * *$ & G1 & $L C$ \\
\hline & Cypriniformes & Cyprinidae & Osteochilus microcephalus & Ostcro & 0.675 & $0.001 * * *$ & G5 & $L C$ \\
\hline & Siluriformes & Pangasiidae & Pangasius & Pannga & 0.374 & $0.039 *$ & G11 & $N A$ \\
\hline & Cypriniformes & Cyprinidae & Paralaubuca barroni & Parrro & 0.619 & $0.001 * * *$ & G4 & $L C$ \\
\hline & Cypriniformes & Cyprinidae & Probarbus labeaminor & Probean & 0.799 & $0.001 * * *$ & G2 & $N T$ \\
\hline & Siluriformes & Bagridae & Pseudomystus siamensis & Pseame & 0.921 & $0.001 * * *$ & G3 & $L C$ \\
\hline & Cypriniformes & Cyprinidae & Puntioplites bulu & Punlu & 0.747 & $0.001 * * *$ & G3 & $D D$ \\
\hline & Cypriniformes & Cyprinidae & Puntius binotatus & Punnot & 0.445 & $0.001 * * *$ & G4 & $N A$ \\
\hline & Cypriniformes & Cyprinidae & Puntius rhombeus & Punomb & 0.48 & $0.003 * *$ & G4 & $N A$ \\
\hline & Cypriniformes & Cyprinidae & Rasbora hobelmani & Rasbel & 0.465 & $0.001 * * *$ & G4 & $N A$ \\
\hline & Cypriniformes & Cyprinidae & Rasbora myersi & Rasers & 0.559 & $0.001 * * *$ & G4 & $N A$ \\
\hline
\end{tabular}




\begin{tabular}{|c|c|c|c|c|c|c|c|c|}
\hline Group & Order & Family & Scientific Name & Short Name & $\begin{array}{l}\text { Statistical } \\
\text { Value }\end{array}$ & P.value & Guild & $\begin{array}{l}\text { IUCN } \\
\text { Category }\end{array}$ \\
\hline & Cypriniformes & Cyprinidae & Rasbora trilineata & Rasili & 0.412 & $0.013 *$ & G4 & $L C$ \\
\hline & Cypriniformes & Cyprinidae & Rasbora aurotaenia & Rasrot & 0.371 & $0.017 *$ & G4 & $L C$ \\
\hline & Siluriformes & Siluridae & Wallago leerii & Waleri & 0.608 & $0.001 * * *$ & G11 & $N A$ \\
\hline \multirow[t]{14}{*}{4} & Siluriformes & Ariidae & Arius maculatus & Aricul & 0.982 & $0.001 * * *$ & G7 & NA \\
\hline & Siluriformes & Ariidae & Arius malacanthus & Arilac & 0.341 & $0.019 *$ & G2 & $N A$ \\
\hline & Batrachoidiformes & Batrachoididae & $\begin{array}{l}\text { Batrachomoeus } \\
\text { trispinosus }\end{array}$ & Batisp & 0.816 & $0.001 * * *$ & G7 & $N A$ \\
\hline & Clupeiformes & Engraulidae & Coilia macrognathos & Coicro & 0.853 & $0.001 * * *$ & G10 & $N A$ \\
\hline & Clupeiformes & Engraulidae & Coilia lindmani & Coindm & 0.92 & $0.001 * * *$ & G7 & $L C$ \\
\hline & Characiformes & Characidae & Colossoma macropomum & Colcro & 0.819 & $0.001 * * *$ & G11 & $N A$ \\
\hline & Pleuronectiformes & Cynoglossidae & Cynoglossus microlepis & Cyncro & 0.819 & $0.001 * * *$ & G10 & $L C$ \\
\hline & Perciformes & Polynemidae & $\begin{array}{l}\text { Eleutheronema } \\
\text { tetradactylum }\end{array}$ & Eletra & 0.703 & $0.001 * * *$ & G7 & $N A$ \\
\hline & Perciformes & Gobiidae & Glossogobius aureus & Gloreu & 0.656 & $0.001 * * *$ & G7 & $L C$ \\
\hline & Siluriformes & Ariidae & Hemiarius stormii & Hemorm & 0.833 & $0.001 * * *$ & G7 & $N A$ \\
\hline & Perciformes & Centropomidae & Lates calcarifer & Lat/ca & 0.634 & $0.001 * * *$ & G10 & $N A$ \\
\hline & Mugiliformes & Mugilidae & Mugil cephalus & Mugpha & 0.662 & $0.001 * * *$ & G10 & $N A$ \\
\hline & Siluriformes & Ariidae & Netuma thalassinus & Netala & 0.737 & $0.001 * * *$ & G7 & $N A$ \\
\hline & Perciformes & Sciaenidae & Nibea soldado & Niblda & 0.913 & $0.001 * * *$ & G10 & $N A$ \\
\hline
\end{tabular}




\begin{tabular}{|c|c|c|c|c|c|c|c|c|}
\hline Group & Order & Family & Scientific Name & Short Name & $\begin{array}{l}\text { Statistical } \\
\text { Value }\end{array}$ & P.value & Guild & $\begin{array}{l}\text { IUCN } \\
\text { Category }\end{array}$ \\
\hline & Siluriformes & Ariidae & Osteogeneiosus militaris & Ostlit & 0.999 & $0.001 * * *$ & G7 & $N A$ \\
\hline & Siluriformes & Pangasiidae & Pangasius krempfi & Panemp & 0.833 & $0.001 * * *$ & G8 & $v U$ \\
\hline & Siluriformes & Pangasiidae & Pangasius polyuranodon & Panlyu & 0.782 & $0.001 * * *$ & G11 & $L C$ \\
\hline & Siluriformes & Plotosidae & Plotosus canius & Ploniu & 0.94 & $0.001 * * *$ & G7 & $N A$ \\
\hline & Perciformes & Polynemidae & Polynemus longipectoralis & Polngi & 0.843 & $0.001 * * *$ & G7 & $N A$ \\
\hline
\end{tabular}

Note:

See sample membership of each group in Annexe 5. 
The PCA conducted with a species matrix (Hellinger transformed) of the 247 species over 228 year-site samples is shown in Figure 3.25. It clearly shows the overlap between Zone 3S and Zone 4 (strong overlap of ellipsoids) in the positive coordinate of axis 1 . This zone was characterized by very rich characteristic species (red arrows). Among them, the most dominant were Hemibagrus spilopterus, Bagrichthys, Hampala dispar, Bagrichthys obscurus, Scaphognathops stejnegeri, Osphronemus goramy, Channa striata, Cirrhinus jullieni, Cyclocheilichthys lagleri, Chitala blanci and Pseudomystus siamensis.

In contrast to this group, Zone 8 (Mekong Delta) is in the negative coordinate of axis 1 (Figure 3.25) with no species contributing significantly to this group; this is in contrast to the species in red text affirming the absence or scarcity of these species in the Delta.

Zone 2 and part of Zone 3 belong to the negative coordinate of axis 2 (Figure 3.25). This group is characterized by species with green arrows. The main species are: Hemibagrus wyckioides,

Cyprinus carpio, Belodontichthys dinema, Bagarius yarrell, Hypsibarbus wetmorei, Bagarius and Mekongina erythrospila.

Tonle Sap stations (Zone 7) were linked to the positive coordinate of axis 2, characterized by two main fish species, Trichogaster trichopterus and Osteochilus hasselti (Figure 3.25).

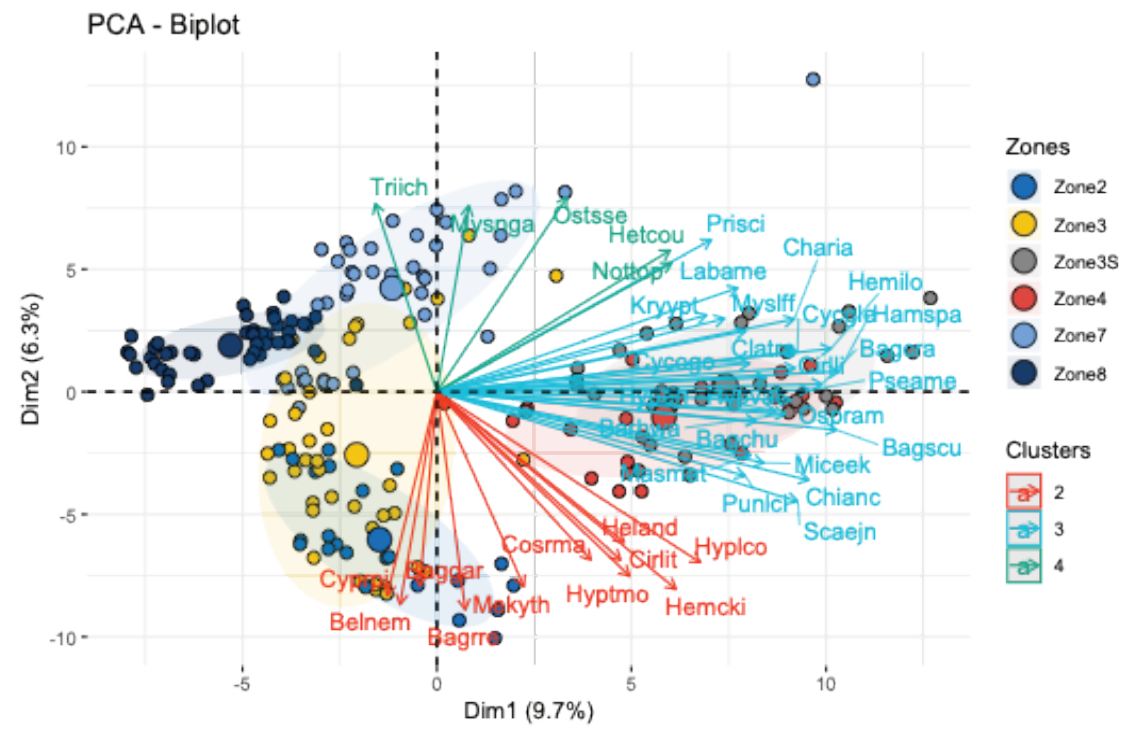

Figure 3.25 PCA on fish community results showing samples by zones (different colours)

Note:

The big dot represents the centroid of each BioRA zone. The ellipsoid (same colour as 
the centroid) corresponds to the 1SD of distribution limit for samples in each zone. Only the 40 species that contributed most are shown (the 207 other species were ignored to ensure visibility of the figure). The colours correspond to the k-means clustering of the species in 3 groups. For the names of the species, refer to Annex 4

Last, the PCA revealed that Zone 3 samples were widely distributed since this zone composes of floodplain, mainstream and tributary habitats/stations at the upper and middle parts of the river. Obviously, it overlaps with Tonle Sap (Zone 7) and the upper part of the river (Zone 2).

\subsubsection{Relationship between fish diversity and abundance with key environmental factors in the LMB}

Water Level

The responses of fish species richness and diversity to water level fluctuation in the LMB are shown in Figure 3.26. The Loess regression fitting shows that richness, diversity indices and evenness increased with water level increases. However, the total relative abundance of fishes in the LMB had an inverse trend; i.e. decreasing relative abundance for high water levels. This was likely due to low fish densities, since fish were widely distributed by seasonal floods to floodplains and inundated forests, which makes them difficult to capture (Ngor, Grenouillet, et al., 2018).

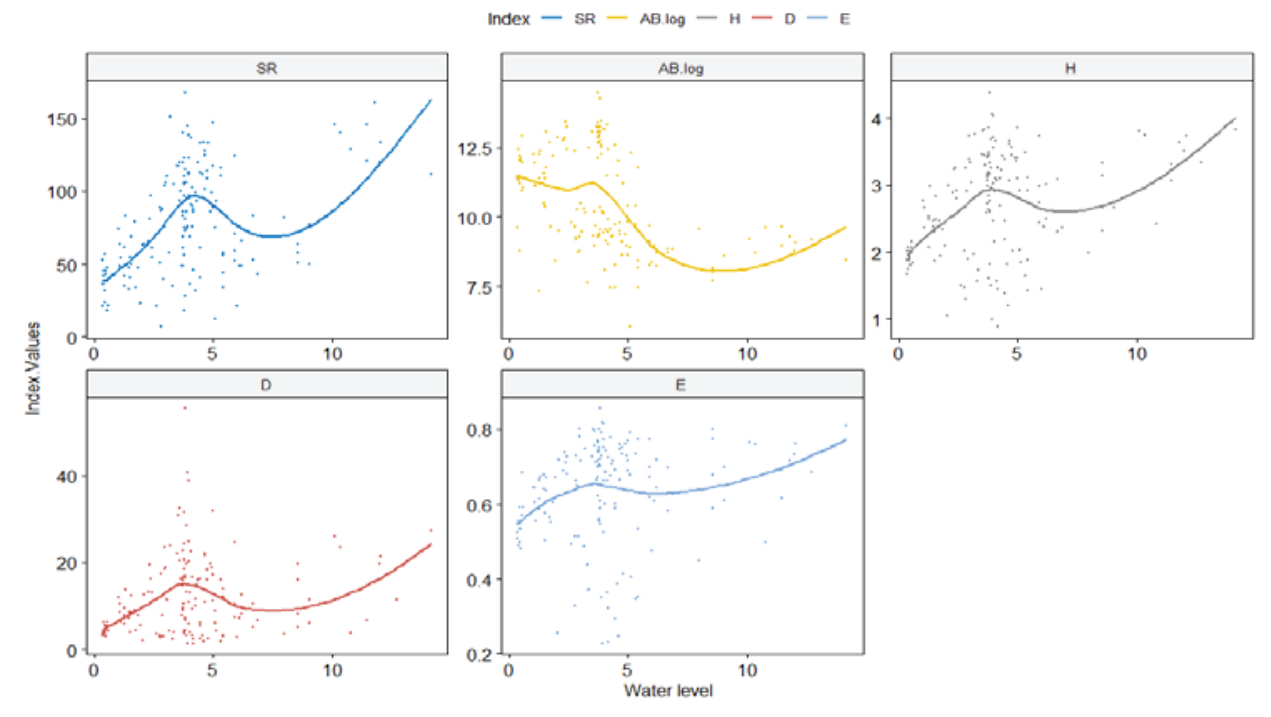

Figure 3.26 Relationship between water level and fish richness, diversity and abundance fitted by Loess curves

Note:

SR: Species richness, AB.log: log of Abundance, H: Shannon-Wiener index, D: Inverse Simpson index, E: Equitability (Evenness) 


\section{Water temperature}

Figure 3.27 shows similar trends for the positive response of fish richness, diversity and evenness to water temperature; i.e. increasing response with increasing water temperatures. Since water temperature has a negative correlation with water level (Figure 3.30), at the low water levels (which have high temperatures), fish were likely not widely dispersed which made them easy to capture (Ngor, Grenouillet, et al., 2018).

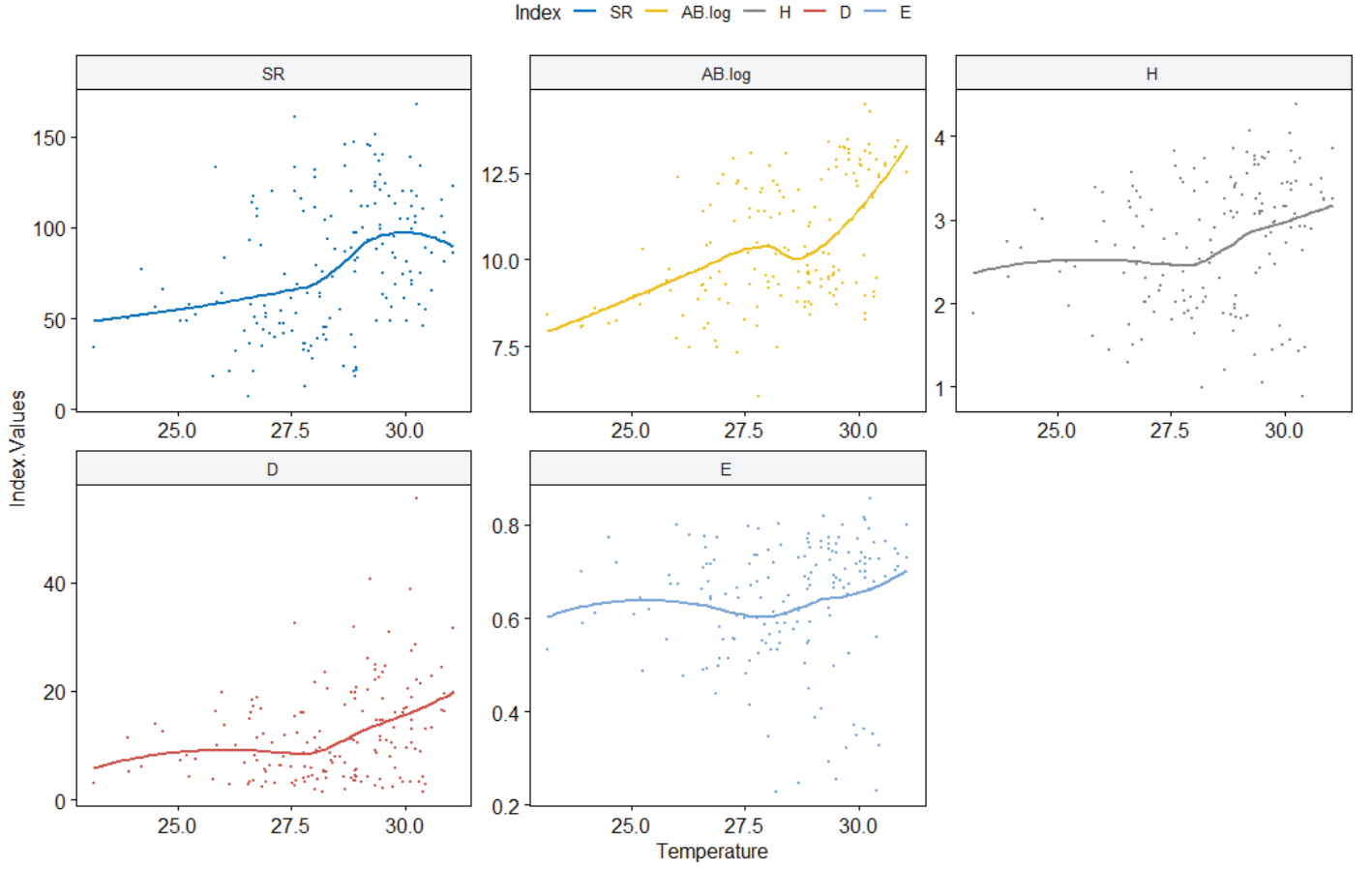

Figure 3.27 Relationship between water temperature and fish richness, abundance and diversity indices fitted by Loess curves

Note:

SR: Species richness, AB.log: log of Abundance, H: Shannon-Wiener index, D: Inverse Simpson index, E: Equitability (Evenness)

\section{Dissolved oxygen}

In relation to Dissolved Oxygen (DO), Figure 3.28 clearly shows a decreasing trend of fish abundance for the high level of DO, whereas the other indices show an increasing trend. The correlation coefficients for Species Richness and Shannon Wiener indices were stronger than the Simpson and Evenness indices. Since DO has a positive correlation with WL (Figure 3.30), a downward trend of fish abundance during high DO is because fish are difficult to capture when water levels are high (Ngor, Grenouillet, et al., 2018). 

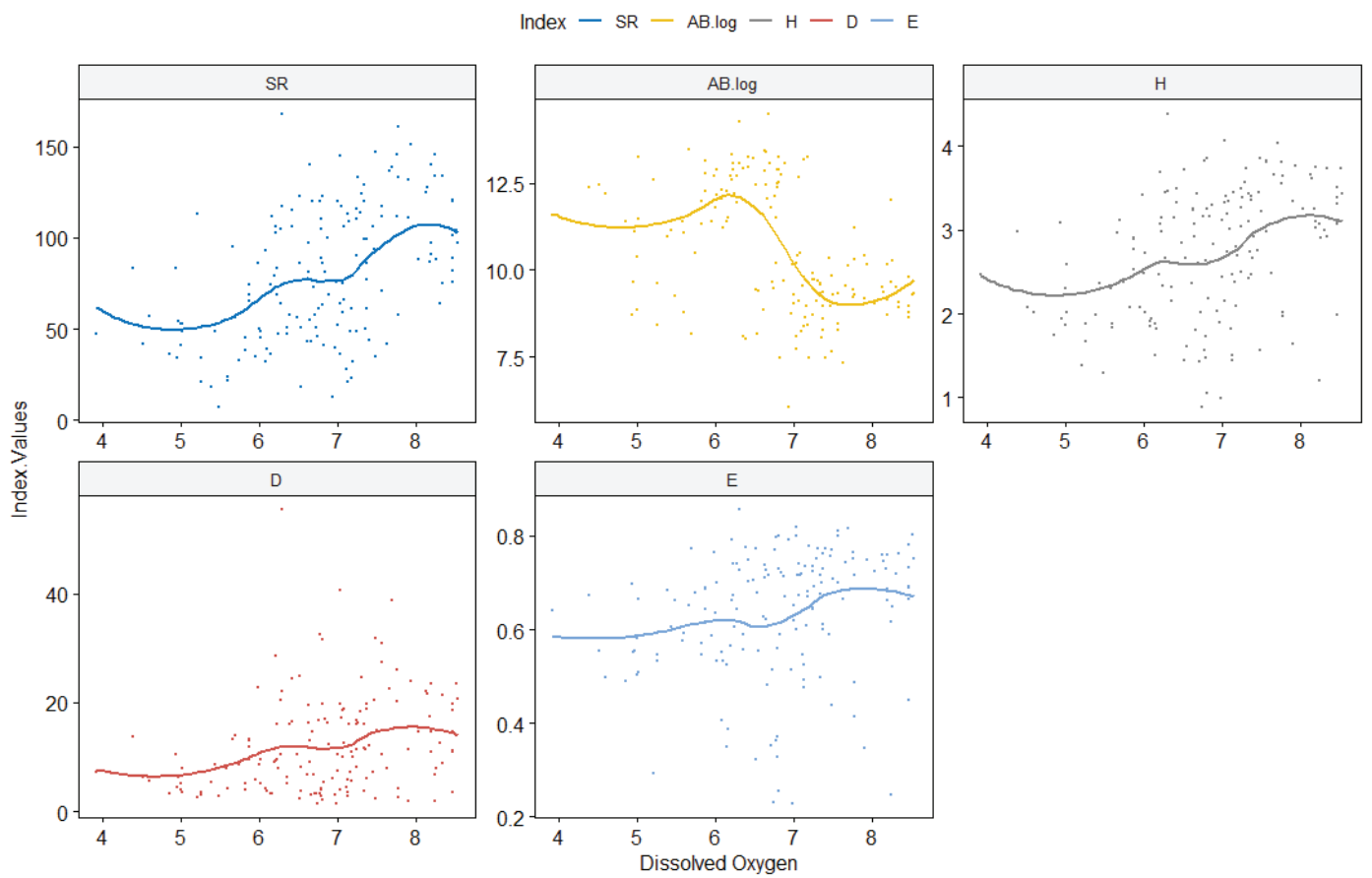

Figure 3.28 Relationship between dissolved oxygen and fish richness, abundance and diversity indices fitted by Loess curves. SR: Species richness, AB.log: log of Abundance, H: Shannon-Wiener index, D: Inverse Simpson index, E: Equitability (Evenness)

pH

The neural $\mathrm{pH}$ environment (around 7.0) gave the highest richness and abundance for both diversity indices (Shannon Wiener and Simpson). However, equitability evenness seemed independent regarding the $\mathrm{pH}$ level (Figure 3.29). 
Index $-\mathrm{SR}-\mathrm{AB} \cdot \log -\mathrm{H}-\mathrm{D}-\mathrm{E}$
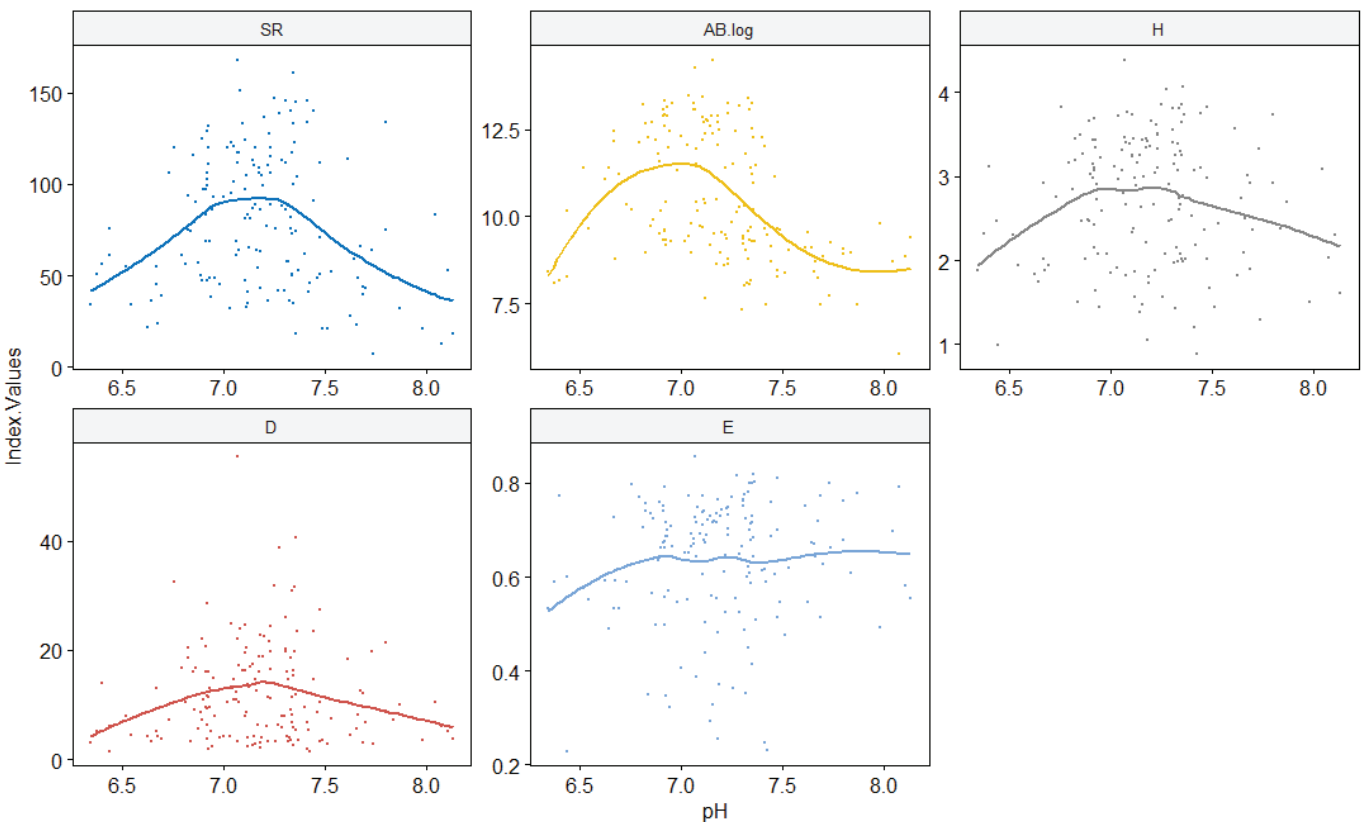

Figure 3.29 Relationship between $\mathrm{pH}$ and fish richness, abundance and diversity indices fitted by Loess curves. SR: Species richness, AB.log: log of Abundance, H: Shannon-Wiener index, D: Inverse Simpson index, E: Equitability (Evenness)

The relationship between both environmental factors and fish composition as well as the correspondence with the samples from different stations and sampling periods are shown in Figure 3.30. Dissolved Oxygen (DO) is positively correlated with Water Level (WL) and are more or less independent from the water temperature (orthogonal position). The highest DO and WL are in the upper part of Cambodia (Zone 4 and Zone 3S). The most abundant species linked to these 2 parameters are Hypsibarbus malcolmi, Bagarius yarrelli, Hemibagrus wyckioides, Helicophagus

waandersii and Puntioplites falcifer. In contrast, the samples with low DO and WL are located in Viet Nam (Zone 8) and the most abundant species are Coilia lindmani, Arius maculatus,

Mystus mysticetus, Puntioplites proctozysron and Labiobarbus lineata. Tonle Sap Lake stations (Zone7) had the highest temperature and the most important species are Osteochilus hasselti, Labiobarbus siamensis, Paralaubuca typus, and Henicorhynchus lobatus. Zone2 and Zone3 from Lao PDR and Thailand had lower temperature. The most abundant species are Bagarius yarrelli, Poropuntius deauratus, Cyprinus carpio, Hypsibarbus vernayi, Pangasius macronema, and Mystus nemurus. The $\mathrm{pH}$, represented by a short arrow in the figure, contributed weakly to the Redundancy Analysis (RDA) and therefore made interpretation impossible. 


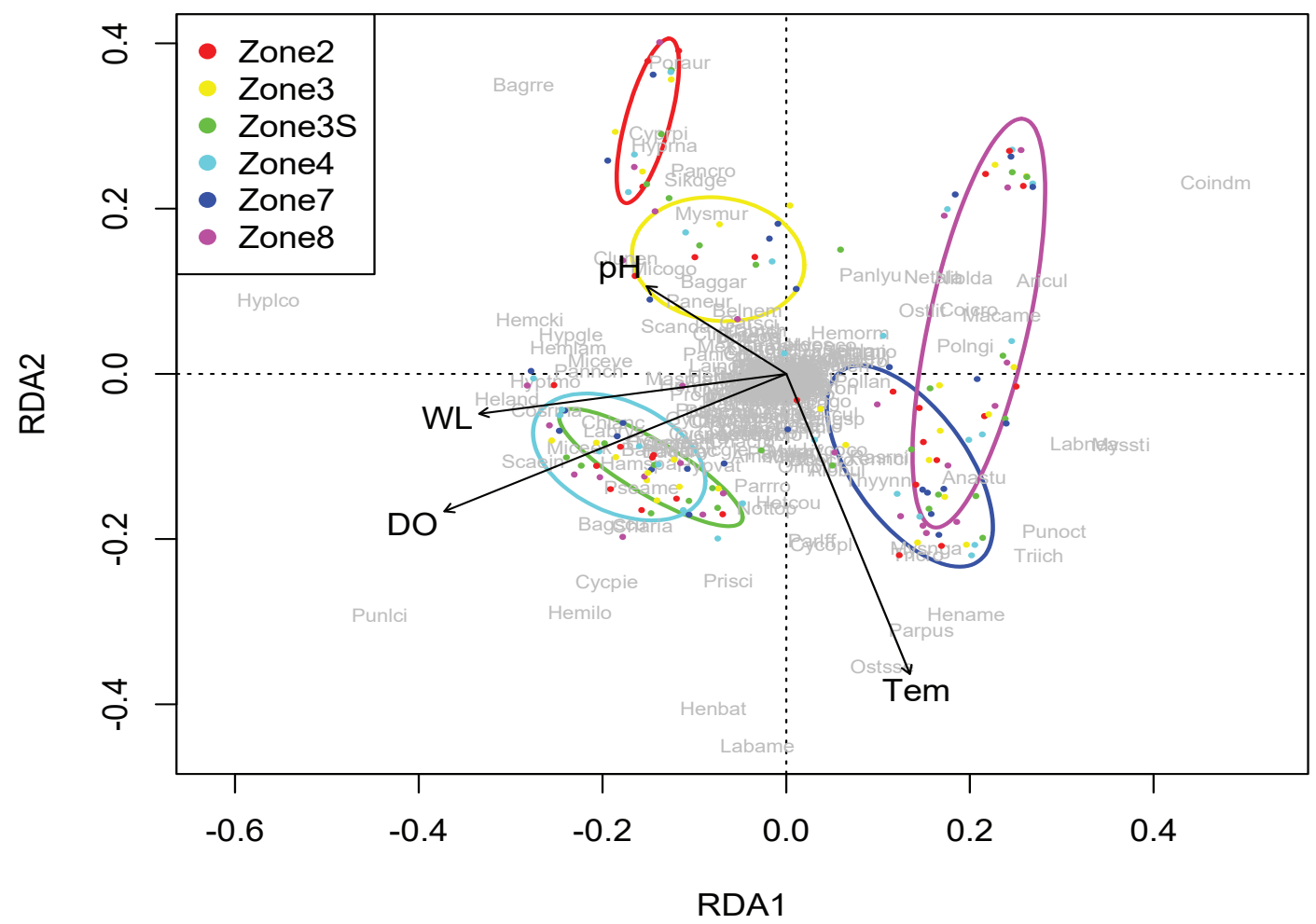

Figure 3.30 Triplot of the Redundancy Analysis (RDA) showing the correspondence between environmental factors and fish, and their related samples in the LMB. The ellipsoids represent the 1SD of sample distribution of the LMB BioRA zones 


\section{4 \\ DISCUSSIONS}

\subsection{FISH DIVERSITY IN THE LMB}

Fish species richness in the Mekong River is ranked as one of the world's highest (Chea et al., 2016; Guégan et al., 1998; Kong et al., 2017; Ngor, Oberdorff, et al., 2018; Winemiller et al., 2016). The LMB accounts for a very low rate of exotic species; $99 \%$ of its fish species are indigenous with most enjoying a 'least concerned' conservation status. Endangered species make up around $2 \%$, threatened species about $10 \%$, and vulnerable species around $3 \%$. The LMB is considered a healthy ecosystems compared to other rivers (Chea et al., 2017; Valbo-Jorgensen et al., 2009). Among the 571 fish species caught by the MRC FADM programme over the past twelve years, the generalist fishes (G5) were dominant in terms of fish abundance followed by the floodplain spawners or grey fishes (G4) and the floodplain residents or black fishes (G6). However, for the relative biomass, it was observed that the main-channel spawners or short-distance white fishes (G3) were the dominant guild followed by generalist fishes (G5).

It is very well known that the number of fish species increases along an upstream-downstream gradient in terms of richness and fish assemblage composition (Chea et al., 2017; Grenouillet et al., 2004; Nuon et al., 2020). In the LMB, around 50 species were recorded in the upstream in Lao PDR (Zone 2) with the number increasing to more than 100 species around the Khone falls area (Zone 4). Zone 3S had very high richness, with 300 species, while the Tonle Sap Lake (Zone 7) and the Mekong Delta (Zone 8) had very high abundance due to the flood-pulse system. Zone 3S also had the highest diversity and evenness indices. Henicorhynchus siamensi and Henicorhynchus lobatus were the most abundant species, while Henicorhynchus siamensis and Puntioplites proctozysron had the highest biomass or catch in the LMB. 
The high diversity and abundance of fish species found in the Tonle Sap area (Zone 7) is due to the river-lake flood-pulse system, which is in agreement with results obtained in most other tropical riverine ecosystems (Chan et al., 2017; Connell, 1978; Kong et al., 2017; Nuon et al., 2020); for example, the high biodiversity of riverine fishes in Lake Malawi. Similarly, most of the fish species caught in the Kisian and Awach Seme rivers also constitute the ichthyofauna community of Lake Victoria (e.g. 22 species) suggesting a close link between the rivers and the lake (Adaka et al., 2014). Campbell, Say, and Beardall (2009) classify Tonle Sap as the heart of the Mekong river system supporting the highest level of fisheries activities (Hortle, 2009; Kong et al., 2017). The low diversity and evenness in the Mekong Delta (Zone 8) can be explained by the strong impact on this zone from high population density, extensive agricultural activities (e.g. rice culture), and intensive aquaculture production (Campbell, 2012; Chan et al., 2017; Chea et al., 2016).

Temporally, both richness and abundance increased during the survey period from 2007 to 2018 in Tonle Sap (Zone 7) and in the Mekong upstream in Southern Lao PDR and Thailand (Zone 3 ), leading to the high diversity of these areas, which corresponded to an increase in sampling effort. This reflects the fact that Tonle Sap is one of the world's most diverse and productive fisheries ( 400,000 tons annually), providing food security and livelihoods for millions of people in the region (Baran et al., 2014; Campbell et al., 2009; Chan et al., 2017; Kong et al., 2017; Ngor, Grenouillet, et al., 2018; Ngor, McCann, et al., 2018; Ngor, Oberdorff, et al., 2018).

However, richness and abundance decreased in Zone 8 (Mekong Delta) and Zone 4 (Mekong at the 35 confluence) due to high human impacts in these areas; for example, intensive agriculture and aquaculture in the Mekong Delta (Campbell, 2012) and hydropower dams in the upstream $3 S$ and Mekong mainstream (Stone, 2016).

The Local Contribution for Beta Diversity (LCBD) showed the spatio-temporal changes of diversity in the LMB, which were higher in the Mekong Delta (Zone 8) and the upper part of the Mekong River in Lao PDR and Thailand (Zone 2 and Zone 3). Lower values of LCBD in the lowlands of the LMB below the Khone Falls and Tonle Sap confirmed that fish communities in these areas were quite stable during the FADM survey period. Five species contribute strongly to the change in diversity during this period (highest SCBD values): one black fish (Anabas testudineus) and four white fish (Henicorhynchus siamensis, Henicorhynchus lobatus, Coilia lindmani, and Sikukia gudgeri).

\subsection{STATUS OF FISH CATCHES IN THE LMB}

Most of the LMB zones are more or less under stress (negative values of W), except Zone 35 with positive values of $\mathrm{W}(0.025)$ testifying that this area was not under stress during the FADM period of 2007-2018. This might be because the Sekong and Srepok rivers flow through large protected areas (e.g. Lumphat, Mondulkiri and Yok Don protected areas) (MRC, 2011) which allows fish to grow to their natural size and biomass without disturbance from fishing. This finding is consistent with prior studies conducted in the Philippines and Bangladesh (Ali et al., 2009; Anticamara et al., 2010). However, this situation can change in the near future due to the number of dams 
operating in the upstream of these 3 river systems (Ngor, Legendre, et al., 2018).

Overall, the fish community of the LMB (in terms of abundance and biomass) was moderately disturbed $(W=-0.03)$. This might stem from numerous anthropogenic pressures such as hydropower dam, agriculture activities, illegal fishing and sand mining. The quarterly interviews between the national fisheries researchers and the participating fishers during the logbook collection provided information about the anthropogenic pressures on fish catches. For example, in Lao PDR, participating fishers acknowledged that it is very difficult to catch fish and they have to spend more time and effort than before. They perceived that some fishing grounds have also changed due to climate change, the cumulative impacts from development projects, and agriculture farming, all of which affect water levels and discharge. The fishers stated that the changing water levels in the dry season at the north monitoring stations (LHT, LDK, LPN, LOX, LPB, LPO, LXB and LNS) in Bokeo, Udomxay, Luangprabang and Xayaburi provinces are partly due to dam development. Also, water from the wet season is very low compared to previous years. This change has allowed fishers to catch more brood stock inhabiting shallow water; however, the fish population may decline in the future.

Another threat to fish catches is the use of illegal fishing gear such as electro fishing and poison, which are still widely used in the northern monitoring stations. If compared to the stations in Vientiane (LVT), illegal activities are fewer since the station is located along the Mekong River near the village. Likewise, the participating fishers in LBX station of Borikhamxay province also reported that illegal fishing occurred not only in the mainstream but also in tributaries, rice fields and wetlands. Although such fishing gear is prohibited by law, it is still used due to a lack of capacity and funding to educate fishers and enforce the law. Moreover, sand mining has been practiced in the downstream Thamuang monitoring station (LVT) in Vientiane. However, the adverse impacts on fish communities, fish catches or fish production are unclear since there have not been any studies on this issue in the region. The participating fishers in Vientiane always refer to an increase in the number of fishers, the use of advance fishing gear and climate change when asked about the factors that influence their catch.

Similar to Lao fishers, the fishers in Thailand from all monitoring stations mentioned that they find it relatively difficult to catch fish and have to spend more time and effort than before. They inferred that it might be an impact from the operation of Xayaburi dam because of the changed condition in certain fishing grounds; for example, very clear water, lots of algae and extreme water shortages. Fishers at TCK, TUT and TKR in Loei, Nakhonphanom, and Ubon Ratchathani provinces noticed changing water levels in the dry season as well as a relatively short flood season, which are partly due to development projects on the Mekong River. Fishers in TUT station stated that sand mining in both Thailand and Lao PDR have negative effects on fish catches and fish production, and also cause erosion and landslides. In addition to the abovementioned threats, fishers reported that illegal fishing has occurred in TKR, TNK and TSK. Also, an increase in the use of insecticide and fertilizer in TSK at the Songkhram River has caused an adverse effect on water quality (algae bloom) and in turn aquatic animals. 
The participating fishers in Cambodia similarly reported that their fish catch has decreased and that the size of fish that they catch reduced. They surmised that the change in fish catch and composition may be a result of development projects, illegal fishing and sand mining. The fishers at all monitoring stations in Cambodia reported that the water level fluctuation is not the same as before (natural pattern). They also stated that illegal fishing has occurred in their fishing grounds. The fishers in CPS, CSK, CSP and CSS affirmed that sand mining has been conducted in a channel/ tributary of Tonle Sap Lake as well as in Sekong, Srepok and Sesan rivers. Many researchers have shown that sand mining can destroy the aquatic plants and benthic animals that are food for many fishes (Boyd et al., 2005; Duan et al., 2008; Pitchaiah, 2017) and also impact on eggs and larvae (Wenger et al., 2017).

In Vietnam, most participating fishers (90\%) reported that their catches have declined over recent years. They also reported that fish size has decreased and fish species composition has changed. Fishers perceived that there are a number of threats (e.g. climate change, population growth, pollution, overfishing, sluice gates and hydropower dams) leading to a decline in fish catches, but the key drivers are (i) the change in flood regime which plays an important role in sustaining fish populations. It has been noticed that water levels in the upstream stations (VAP, VTS and VCM) in An Giang province in the Mekong Delta is very low in comparison with previous years. The fishers found that the onset of flood season is later and the flood period relatively short. Consequently, the fishers at the downstream stations (VTV, VLT and VVL) in Vinh Long and Tra Vinh provinces observed high seawater intrusion due to lower freshwater levels; and (ii) population growth is posing a major threat to fishery resources since the demand for fish has also increased. That is why fishers intend to use modern fishing gear.

\subsection{FISH ASSEMBLAGE AND THE INFLUENCE OF ENVIRONMENTAL FACTORS}

The similarity of the fish communities in the LMB enables 4 clusters to be defined: i) the LMB upstream community from the China-Lao PDR border to Khone Falls (Zone 2 and Zone 3), with 12 indicator species; ii) the cluster downstream of Khone Falls with the complex 3 S rivers (Zone 4 and Zone 3S), with 7 indicator species; iii) the cluster of the Tonle Sap system (Zone 7) and some samples from the Mekong Delta (Zone 8), with 52 indicator species; and iv) the specific cluster of the Mekong Delta, with 18 indicator species mostly from estuarine species. Classification in the LMB clearly showed zonation from up to downstream according to fish community composition similar to temperate rivers (Lasne et al., 2007). However, the LMB is characterized by an impressive number of fish species in each zone linked to the high diversity of the Mekong ecosystems compared to other tropical rivers (Englmaier et al., 2020).

The correspondence between fish distribution and environmental factors has been documented by several researchers (Chan et al., 2017; Chea et al., 2017; Ngor, Grenouillet, et al., 2018; Pool et al., 2019) and they confirmed longitudinal changes of fish assemblages along an upriverdownriver gradient (Lasne et al., 2007; Poff \& Allan, 1995). In the LMB, fish richness and diversity 
increase with water levels, but maximal abundance occurs during the low water-level period. Abundance becomes lower during the very high-water level period due probably to the higher dispersion of fishes and a decrease in catch efficiency (Ngor et al., 2018). Poff and Allan (1995) state that fish assemblage is strongly linked to hydrological variability.

All diversity and abundant indices respond positively to increases in water temperature. It is well known that temperature is an important factor controlling fish diversity in streams (Chu et al., 2008). Leuven et al. (2011) stresses that rising water temperature increases fish richness in European rivers, but mostly benefits exotic species due to their high tolerance for temperature variation compared to native species. In South America, Cussac and colleagues mentioned that river and marine fish diversity is driven by temperature. In the LMB, temperature correlated positively and significantly with all diversity indices, with a higher correlation for species richness and abundance compared to other indices.

Dissolved oxygen is an important parameter controlling fish communities. Howell and Simpson (1994) show that both abundance and diversity decreased markedly with bottom DO dramatically declining to lower than $2 \mathrm{mg} / \mathrm{l}$. Of the 18 species examined, 15 were found to occur at the sites with DO $>3 \mathrm{mg} / \mathrm{l}$ compared to sites with <2 mg/l. In West-Africa, Kouamélan, Teugels, N'Douba, Gooré Bi, \& Koné (2003) showed a significant correlation between species distribution and environmental factors with oxygen an important variable influencing fish distribution. Several research papers showed the important role of DO on freshwater fish abundance and diversity (Justus et al., 2014; Lima-Junior et al., 2006; Rocha et al., 2009). In the LMB, richness and diversity increased with high DO (which has a positive correlation with water levels), but abundance decreased because fish were widely dispersed and difficult to capture (Ngor et al., 2018).

It is well known that the acidity and alkalinity of the water is an important factor for freshwater fish development (detailed in the European Inland Fisheries Advisory Commission Working Party on Water Quality Criteria for European Freshwater Fish, 1969). The pH range which is not directly lethal to fish ranges from 5-9. The $\mathrm{pH}$ values lower than 5 and higher than 10 are considered lethal for fish although some species may be acclimated outside of this range. The changes of $\mathrm{pH}$ induce disruption of the chemosensory abilities of fish populations and modify the association preference in fish communities (Kleinhappel et al., 2019). Several researchers have shown the important role of $\mathrm{pH}$ for fish development (Mount, 1973; Rask, 1984). In the LMB, pH values ranged in the lethal scale for fish development from 6 to 8.5. The maximal richness, abundance and diversity in the LMB appears linked to the neutral $\mathrm{pH}$ values, at around $\mathrm{pH} 7$.

The distribution and abundance of fish communities are governed by various environmental factors (Kwon et al., 2012, Sá-Oliveira et al., 2016). In the LMB, Redundancy Analysis (RDA) showed the correlation between Dissolved Oxygen (DO) and Water Level (WL) especially in the lower part of the LMB (except for the Mekong Delta). The associated species were white species (Hypsibarbus malcolmi, Bagarius yarrelli, Hemibagrus wyckioides, Helicophagus waandersi, and Puntioplites falcifer). In contrast, the low DO and lower WL at the Mekong Delta were good habitats for black or grey fish species, e.g. Coilia lindmani, Arius maculatus, Mystus mysticetus, Puntioplites proctozysron, and Labiobarbus lineata. In the LMB, the temperature was independent 
of DO and WL. The higher temperature area in the LMB includes the Tonle Sap stations and some parts of the lower reaches of the Basin (VAP and VCM), while the lowest temperature area is at the upstream stations in Lao PDR and Thailand (Zone 2 and Zone 3). The fish community characterized by the higher temperatures were Labiobarbus siamensis, Osteochilus hasselti, and by lower temperatures Poropuntius deauratus and Bagarius yarrelli. Canonical analysis (RDA) showed that $\mathrm{pH}$ did not contribute to the LMB's fish community assemblage.

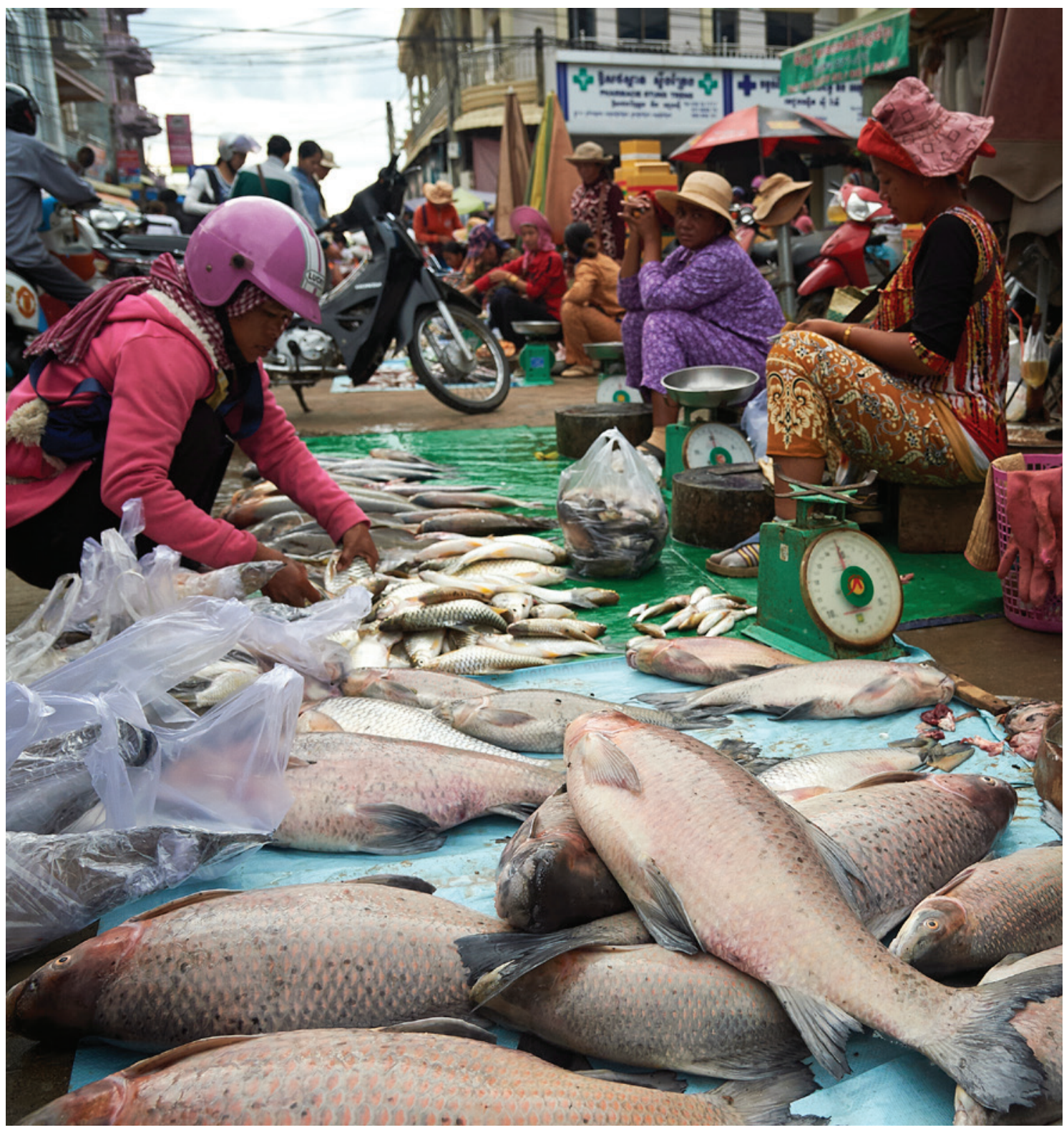




\section{5}

\section{CONCLUSIONS}

This study is the first ever large scale study that considers both spatial and temporal variations of fish abundance and diversity in the LMB using the MRC's long-term fisheries monitoring data. In this section, we conclude our findings in relation to the specific objectives of the study as follows:

1. Contribution of fish species and guilds to the fisheries of the LMB: The MRCFADM programme in the LMB from 2007 to 2018 found 617 fish species ${ }^{1}$ belonging to 21 orders and 80 families. Cypriniformes and Cyprinidae were the dominant order and family, respectively. Over the monitoring period, the catch (i.e. number of individuals or relative abundance and relative biomass) was driven by small-sized or short-lived fish species, such as Henicorhynchus $(H$. siamensis and $H$. lobatus). Moreover, the LMB was dominated by the generalist fishes (G5), the main-channel spawners or short-distance white fishes (G3), the floodplain spawners or grey fishes (G4) and the floodplain residents or black fishes (G6). Regarding conservation status, most fish caught were under the 'least concerned' status. The LMB accounted for a very low rate of exotic species ( $<1 \%$ of abundance or about $1.5 \%$ of biomass).

2. The status and trends of fish catches in the LMB: At the country level, Cambodia had an upward trend for fish catch rates at most of the FADM stations (eight out of 11 stations). In Lao PDR, the catch rate appeared to have dropped slightly since the fish catch rate showed a decreasing trend at two of four stations. Unlike Lao PDR, the catch rate in Thailand increased slightly as four out of five stations showed increasing and stable trends. For Viet Nam, the trend decreased as three of the five stations showed the downward trends. In regard to the BioRa zones, the trend for the catch rates decreased at Zone 2, Zone 8 and Zone 3S, with the rest showing an increasing trend. Regarding the status of the fish community, all zones appeared to be stressed or disturbed, except Zone 3S. Moreover, the study 
suggests that the $A B C$ curves of the fish community in the $L M B$ were moderately disturbed.

3. Spatial and temporal changes in fish diversity and abundance: It is evident that the lower part of Viet Nam (Mekong Delta) had high species turnover across the survey period. This was the same for certain stations in the upstream parts of the river in Thailand and Lao PDR. Yet, the fish species composition at Tonle Sap and 35 were quite stable. Spatially, the study confirms that the upper and lower parts of the LMB (Zone 2 and Zone 8) had the lowest species richness, while the north-eastern part of Cambodia (Zone 4) had the highest. Regarding relative fish abundance, the Tonle Sap Lake and River (Zone7 ) had the highest fish abundance, while the upper part of the LMB (Zone 2) showed the lowest abundance. Temporally, trends of species richness and abundance in areas near confluences with Xe Bang Fei and Nam Kam as well as the Tonle Sap area (Zone3 and Zone7) moved upwards, but those of the north-eastern part of Cambodia and the Viet Nam Mekong Delta (Zone 4 and Zone 8) moved downwards. In relation to spatial changes in species diversity indexes, $3 \mathrm{~S}$ was found to be the highest zone for the three indexes used. The lowest zone was the Viet Nam Mekong Delta (Zone 8). The temporal variation of these three indexes occurred, but with no significant differences.

4. Fish community patterns and their relationship with key environmental factors: Fish communities in the LMB were classified into four groups based on their similarity. Cluster 1 mostly contained fish species at the upstream of the LMB, where most parts of the river border Lao PDR and Thailand. Also, six indicator species found in this cluster belonged to three guilds: grey fish (G4), black fish (G6) and estuarine resident (G7). Cluster 2 was mostly made up by the floodplain, tributary and canal fish communities at Tonle Sap Lake, the middle section of the LMB, and Viet Nam's Mekong Delta. This cluster was also home to 14 indicator species with five guilds, with the dominant one a short-distance white fish (G3). Cluster 3 mostly comprised fish communities at the north-eastern part of Cambodia with 57 indicator species and two dominant guilds: the shortdistance white fish (G3) and grey fish (G4). The last cluster mainly consisted of fish communities at the stations adjacent to the sea with 19 indicator species, divided into five guilds. Estuarine resident (G7) and marine visitor (G10) were the dominant guilds in this cluster. In the LMB, fish diversity and richness had a significant link to temperature, Dissolved Oxygen (DO) and a neutral $\mathrm{pH}$ of around 7. This study indicated that fish communities in Zones 4 and 35 at the upper part of Cambodia are associated with high DO and WL, in contrast to that of Zone 8 in the Viet Nam Mekong Delta. Moreover, fish communities in Zone 7 at Tonle Sap Lake and some parts of Zone 8 had a strong relationship with high temperatures in contrast to those of Zone 2 and Zone 3 in Lao PDR and Thailand with lower temperatures and higher $\mathrm{pH}$ levels. 


\section{6}

\section{RECOMMENDATIONS}

- Fish diversity and abundance needs to be preserved to sustain food supplies for millions of people living in the LMB.

- A number of hydropower projects have been built and proposed in the mainstream. Also, fisheries monitoring stations are not located close to the project sites, which makes it difficult to develop a baseline before the hydropower projects are operational. Thus, it is critical to set up more monitoring stations close to dam sites. This will enable hydropower projects in the Mekong mainstream to be assessed in terms of their impact. MRC's Joint Environmental Monitoring Guideline should be consulted when selecting monitoring stations close to dam sites.

- As mentioned earlier, data has been collected by participating fishers who use multiple types of gear to catch fish. Thus, it is suggested that standardized gear, for example multiple panel gillnets, be used in the FADM programme to strengthen results.

- The results of $A B C$ curves showed that fish communities in almost all zones were disturbed, so it is crucial that the governments of the four MCs jointly enforce fisheries laws and restore key habitats and connectivity within and between zones. Importantly, integrated river management plans should consider new threats resulting from hydropower development.

- Transboundary Fish Protected Areas (PAs) or transboundary Fish Conservation Zones should be set up to maintain biodiversity in the LMB, especially during spawning, egg and larvae development periods.

- As the current study mainly focuses on the current climate regardless of climate change, a study on the impact of climate change on fish abundance and diversity in the LMB should be conducted.

- A study on the impact of sand mining on fish populations and fisheries in the LMB should be carried out to assist policy makers in formulating policy to minimize the impact of sand mining. 


\section{GLOSSARY}

Abundance

Alien species

Analysis of covariance

(ANCOVA)

\section{Analysis of variance \\ (ANOVA)}

\section{Aquaculture}

Average

Biodiversity

Biodiversity indices

Biomass

Brackish water

Canonical Correlation Analysis or CCA is a measure of how many fish are in a population or a fishing zone.

A species occurring in an area outside of its historically known natural range as a result of intentional or accidental dispersal by human activities (also known as an exotic or introduced species).

is a general linear model which blends ANOVA and regression. ANCOVA evaluates whether the means of a dependent variable are equal across levels of a categorical independent variable often called a treatment, while statistically controlling for the effects of other continuous variables that are not of primary interest, known as covariates or nuisance variables.

A statistical procedure for analysing experimental data. It is a collection of statistical models and their associated estimation procedures (such as the "variation" among and between groups) used to analyse the differences among group means in a sample. ANOVA provides a statistical test of whether two or more population means are equal, and therefore generalizes the t-test beyond two means.

the farming of freshwater and saltwater organisms including molluscs, crustaceans and aquatic plants.

An ambiguous term. It often denotes the arithmetic mean, but it can also denote the median, the mode, the geometric mean, and weighted means, among other things. Beware if something reports "the average" without making it clear which average.

is the variation of life forms within an area. In the context of fisheries the number and variety of organisms found within a fishery.

are measures of species diversity expressed as ratios between numbers of species and - importance values\| (numbers, biomass, productivity and so on) of individuals. The term may also refer to genetic diversity and diversity of habitats or communities

the total weight of a fish species in a given area. Can be measured as the total weight in tons of a stock in a fishery, or can be measured per square metre or square kilometre.

water that has more salinity than fresh water, but not as much as seawater. It may result from mixing seawater with fresh water, as in delta or estuaries.

The purpose of CCA is to explain or summarize the relationship between two sets of variables by finding a linear combinations of each set of variables that yields the highest possible correlation between the composite variable for set $A$ and $B$ 
Chi-square Statistic.

Classification:

Climate change

Cluster analysis

Coefficient of determination

Coefficient of
variation (CV)

Community of species

Confidence Interval

Confidence interval

Correlation

Correlation coefficient
The chi-square statistic is used to measure the agreement between categorical data and a multinomial model that predicts the relative frequency of outcomes in each possible category.

the process of simplifying complex, and sometimes continuous, data and information and converting it into practical categories to make it more usable. Through classification, attributes can be classified into categories, independent of one another, enabling synthesis of the parts (components) and processes of different ecosystems

variation in the Earth's global climate or in regional climates over time. Climate change involves changes in the variability or average state of the atmosphere over time periods ranging from decades to millions of years. These changes can be caused by natural processes on Earth, external factors including variations in sunlight intensity, and more recently by human activities.

A general approach to multivariate problems in which the aim is to see whether the individuals into groups or clusters. There are several methods of procedure; most depend on setting up a metric to define the "closeness" of individuals. Generally used when the number and nature of the groups are not known.

The percentage of variation in a variable explained by one or more of the others. In a simple linear regression setup, this is square of the correlation coefficient. In a multiple linear regression setup, this is square of the multiple correlation coefficient. In some other setups, this is explained sum of squares as proportion of total sum of squares.

The standard deviation of a random variable divided by the mean. Result expressed frequently as percentage.

A community of species is an assemblage of organisms characterised by a distinctive combination of species occupying a common environment and interfacing with one another

A confidence interval for a parameter is a random interval constructed from data in such a way that the probability that the interval contains the true value of the parameter can be specified before the data are collected.

A confidence interval is an interval which has a known and controlled probability (generally $95 \%$ or $99 \%$ ) to contain the true value.

In its most general sense correlation denoted the interdependence between quantitative or qualitative data. In this sense it would include the association of dichotomised attributes and the contingency of multiply-classified attributes. The concept is quite general and may be extended to more than two variates.

The word is most frequently used in a somewhat narrower sense to denote the relationship between measurable variates or ranks.

The correlation coefficient $r$ is a measure of how nearly a scatterplot falls on a straight line. The correlation coefficient is always between -1 and +1 . 
Correlation coefficient

Correlation

\section{Correspondence analysis (CA) or Correspondence Factor Analysis}

Dendrogram

Dependent variable

Ecoregion Ecozone

Endangered species

Endangered species

Endemic

Estuary

Eutrophication

Explanatory Variable

Fish assemblage

Fish community
A correlation coefficient is a measure of the degree to which two variables tend to move together. The coefficient has a value between plus and minus 1 , which indicates the strength and direction of association

A measure of linear association between two (ordered) lists. Two variables can be strongly correlated without having any causal relationship, and two variables can have a causal relationship and yet be uncorrelated.

is an approach to representing categorical data in a Euclidean space, suitable for visual analysis. CA is often used where the data (in the form of a two-way contingency table) have many rows and/or columns and are not easy to interpret by visual inspection. The map obtained by CA helps reveal relationships within the table. CA is used in ecology, market research, and other areas.

is a graphical representation of the results of hierarchical cluster analysis. This is a tree-like plot where each step of hierarchical clustering is represented as a fusion of two branches of the tree into a single one. The branches represent clusters obtained on each step of hierarchical clustering.

A variable that is sought to be explained by one or more of the other variables. The dependent variable " $y$ " is generally the outcome of interest whereas independent variables (x1 ...xn) are the antecedents.

is a homogeneous area of one or more ecosystems that interact with relatively self-contained human activities

An endangered species is a population of an organism which is at risk of becoming extinct. The IUCN has calculated the percentage of endangered species as 40 percent of all organisms based on the sample of species that have been evaluated through to 2006.

are taxa in danger of extinction and whose survival is unlikely if causal factors continue operating.

native to a certain ecological region, often a fairly small local area.

a semi-enclosed coastal body of water with one or more rivers or streams flowing into it, and with a free connection to the open sea. Healthy estuaries can have high rates of biological productivity.

an increase in chemical nutrients - typically compounds containing nitrogen or phosphorus - in an ecosystem. Eutrophication in water often results in an increase in algae growth and decay, which can lead to decreased levels of oxygen and fish populations.

Explanatory variable is a synonym for independent variable.

is a group of associated animals living in the same geographical environment.

is a group or association of populations of two or more different species occupying the same geographical area at the same time. Community ecology also takes into account abiotic factors e.g. temperature, oxygen, $\mathrm{pH}$... 
Fisherman or Fisher

Fishery

Fishing

General Linear Model - GLM

Gillnet

\section{Hierarchical cluster analysis (or hierarchical clustering)}

Histogram

Independent variable

Indicator species or Indicative species

Invasive species someone who captures fish and other animals from a body of water.

the activities leading to and resulting in the harvesting of fish. A fishery is characterised by the species caught, the fishing gear used, and the area of operation.

the activity of trying to catch fish

General (or generalized) linear models (GLM), in contrast to linear models, allow you to describe both additive and non-additive relationship between a dependent variable and $\mathrm{N}$ independent variables. The independent variables in GLM may be continuous as well as discrete. (The dependent variable is often named "response", independent variables - "factors" and "covariates", depending on whether they are controlled or not).

fishing nets constructed so that fish are entangled or enmeshed, usually in the gills, by the netting. According to their design, ballasting and buoyancy, these nets can be used to fish on the surface, in midwater or on the bottom.

is a general approach to cluster analysis, in which the object is to group together objects or records that are "close" to one another. A key component of the analysis is repeated calculation of distance measures between objects, and between clusters once objects begin to be grouped into clusters. The outcome is represented graphically as a dendrogram.

A diagram showing the number or percentage of subjects with values in different intervals by means of contiguous bars: used only for quantitative variables.

This term is regularly used in contradistinction to "dependent variable" in regression analysis. When a variate $y$ is expressed as a function of variables $x$, plus a stochastic term the x's are known as "independent variables".

A species whose status provides information on the overall condition of the ecosystem and of other species in that ecosystem. Such species are described as playing a critical role in maintaining the structure of an ecological community, affecting many other organisms in an ecosystem and helping to determine the types and numbers of various other species in the community.

Indicator species are indicative of particular groups of sites. Good indicator species should be found mostly in a single group of a typology and be present at most of the sites belonging to that group.

Invasive species are those that are introduced-intentionally or unintentionallyto an ecosystem in which they do not naturally appear and which threaten habitats, ecosystems, or native species. These species become invasive due to their high reproduction rates and by competing with and displacing native species, that naturally appear in that ecosystem. Unintentional introduction can be the result of accidents (e.g. when species escape from a zoo), transport (e.g. in the ballast water of a ship); intentional introduction can be the result of e.g. importing animals or plants or the genetic modification of organisms. 
IUCN

IUCN Red List

k-means clustering

Kruskal - Wallis Test

Linear correlation

Linear Regression

Log-Normal

Distribution

Mann-Whitney test

Mean, Arithmetic mean

Median

Multiple (linear) regression the International Union for the Conservation of Nature and Natural Resources is the world's main authority on the conservation status of species. Their system divides threatened species into three categories: critically endangered (CR), endangered (EN), and vulnerable (VU). They also list extinctions that have occurred since 1500 $A D$ and taxa that are extinct in the wild.

the IUCN Red List of Threatened Species (also known as the IUCN Red List or Red Data List), created in 1963, is the world's most comprehensive inventory of the global conservation status of plant and animal species.

The k-means clustering method is used in non-hierarchical cluster analysis. The goal is to divide the whole set of objects into a predefined number ( $k$ ) of clusters. The criteria for such subdivision is normally the minimal dispersion inside clusters - e.g. the minimal sum of squares of the distances from the mean vector (centroid) of the cluster. A direct rigorous solution to this problem requires testing of an impractically large number of data subdivisions. The k-means clustering is a fast heuristic method that provides a reasonably good solution, although not optimal.

The Kruskal-Wallis test is a nonparametric test for finding if three or more independent samples come from populations having the same distribution. It is a nonparametric version of ANOVA.

An obsolete expression once used to denote either (a) the product moment correlation in cases where the corresponding regressions were linear or (b) a coefficient of correlation constructed from linear functions of the observations. The expression is best avoided altogether.

Linear regression is aimed at finding the "best-fit" linear relationship between the dependent variable and independent variable(s). See also: Regression analysis, Simple linear regression, Multiple regression

A random variable $X$ has a log-normal distribution if $\ln (X)$ is normally distributed.

A nonparametric test for comparing central tendency in two groups: analogous to t-test for Gaussian data. Gives exactly same result as Wilcoxon test for paired samples.

The sum of a list of numbers, divided by the number of elements in the list. See also average.

"Middle value" of a list. The smallest number such that at least half the numbers in the list are no greater than it. If the list has an odd number of entries, the median is the middle entry in the list after sorting the list into increasing order. If the list has an even number of entries, the median is the smaller of the two middle numbers after sorting. The median can be estimated from a histogram by finding the smallest number such that the area under the histogram to the left of that number is $50 \%$.

is a regression technique aimed at finding a linear relationship between the dependent variable and multiple independent variables. 
Native species

Nonparametric Tests

Parametric Tests

Predictor Variable

Principal Component

Analysis (PCA)

Red List

Redundancy analysis

(RDA)

Regression, Linear
Regression

Residuals

Scatter diagram or Scatter plot
Flora and fauna species that occur naturally in a given area or region. Also referred to as indigenous species.

In statistical inference procedures (hypothesis tests and confidence intervals), nonparametric procedures are those that are relatively free of assumptions about population parameters.

In statistical inference procedures (hypothesis tests and confidence intervals), parametric procedures are those that incorporate assumptions about population parameters.

Predictor variable is a synonym for independent variable. See also: dependent and independent variables.

The purpose of principal component analysis is to derive a small number of linear combinations (principal components) of a set of variables that retain as much of the information in the original variables as possible.

The IUCN Red List of Threatened Species provides taxonomic, conservation status and distribution information on taxa that have been globally evaluated using the IUCN Red List Categories and Criteria. This system is designed to determine the relative risk of extinction, and the main purpose of the IUCN Red List is to catalogue and highlight those taxa that are facing a higher risk of global extinction (i.e. those listed as Critically Endangered, Endangered and Vulnerable). The IUCN Red List also includes information on taxa that are categorized as Extinct or Extinct in the Wild; on taxa that cannot be evaluated because of insufficient information (i.e. are Data Deficient); and on taxa that are either close to meeting the threatened thresholds or that would be threatened were it not for an ongoing taxon-specific conservation programme (i.e. are Near Threatened).

is a method to extract and summarise the variation in a set of response variables that can be explained by a set of explanatory variables. More accurately, RDA is a direct gradient analysis technique which summarises linear relationships between components of response variables that are "redundant" with (i.e. "explained" by) a set of explanatory variables. To do this, RDA extends multiple linear regression (MLR) by allowing regression of multiple response variables on multiple explanatory variables. A matrix of the fitted values of all response variables generated through MLR is then subject to principal components analysis (PCA). Detailed discussion is available in Legendre and Legendre (1998).

Linear regression fits a line to a scatterplot in such a way as to minimize the sum of the squares of the residuals. The resulting regression line, together with the standard deviations of the two variables or their correlation coefficient, can be a reasonable summary of a scatterplot if the scatterplot is roughly football-shaped.

Residuals are differences between the observed values and the values predicted by some model. Analysis of residuals allows you to estimate the adequacy of a model for particular data; it is widely used in regression analysis.

A diagram displaying values of one quantitative variable for different values of the other variable by plotting points. This is also called the $(x, y)$ plot. 


\section{Scatterplot}

Significance, Significance level, Statistical significance

Simpson index

Species richness

Species richness or Richness

Standard Deviation (SD)

Standard Error (SE)

t-test

t-test or Student t-test
A scatterplot is a way to visualize bivariate data. A scatterplot is a plot of pairs of measurements on a collection of "individuals". For example, suppose we record the lengths and weights of a group of 100 fish. The scatterplot of those data would be 100 points. Each point represents one fish's length and weight. In a scatterplot of weight against length, the x-coordinate of each point would be length of one fish, the $y$-coordinate of that point would be the weight of the same fish. In a scatterplot of length against weight, the $x$-coordinates would be the weights and the $y$-coordinates would be the lengths.

The significance level of a hypothesis test is the chance that the test erroneously rejects the null hypothesis when the null hypothesis is true.

Simpson's Diversity Index is a measure of diversity which takes into account the number of species present, as well as the relative abundance of each species.

is the number of different species represented in an ecological community, landscape or region. Species richness is simply a count of species, and it does not take into account the abundances of the species or their relative abundance distributions. Species richness is sometime considered synonymous with species diversity, but the formal metric Species diversity takes into account both species richness and species evenness.

is the number of different species represented in an ecological community, landscape, or region. Species richness is simply a count of species, and it does not take into account the abundances of the species or their relative abundance distributions.

The standard deviation of a set of numbers is the rms of the set of deviations between each element of the set and the mean of the set.

The Standard Error of a random variable is a measure of how far it is likely to be from its expected value; that is, its scatter in repeated experiments.

A hypothesis test based on approximating the probability histogram of the test statistic by Student's t curve. t-tests usually are used to test hypotheses about the mean of a population when the sample size is intermediate and the distribution of the population is known to be nearly normal.

A statistical procedure to test hypothesis of equality of two means, and for certain other hypotheses relating to parameters such as regression coefficient 
Threatened species

A technical classification referring to a species that is likely to become endangered within the foreseeable future, throughout all or a significant portion of its range. 12,259 species are known by IUCN, the World Conservation Union, to be threatened with extinction. IUCN keeps the world's inventory of the conservation status of animals and plants, compiling data from thousands of scientists and conservationists worldwide. However, the 12,259 threatened species are only the tip of the iceberg. Nobody knows how many species there are on Earth, let alone how they are doing. The total number of recorded living species is around 1.75 million. But more than two thirds are insects and other invertebrates, which are extremely difficult to monitor. An estimate of the real number of species on Earth is 14 million. For its 2003 "Red List of Threatened Species", IUCN was able to evaluate the conservation status of $2 \%$ of 1.53 million species for which it has descriptions. The only two well-monitored groups are birds and mammals, so IUCN was able to evaluate $100 \%$ of birds and $99 \%$ of mammals for threatened status.

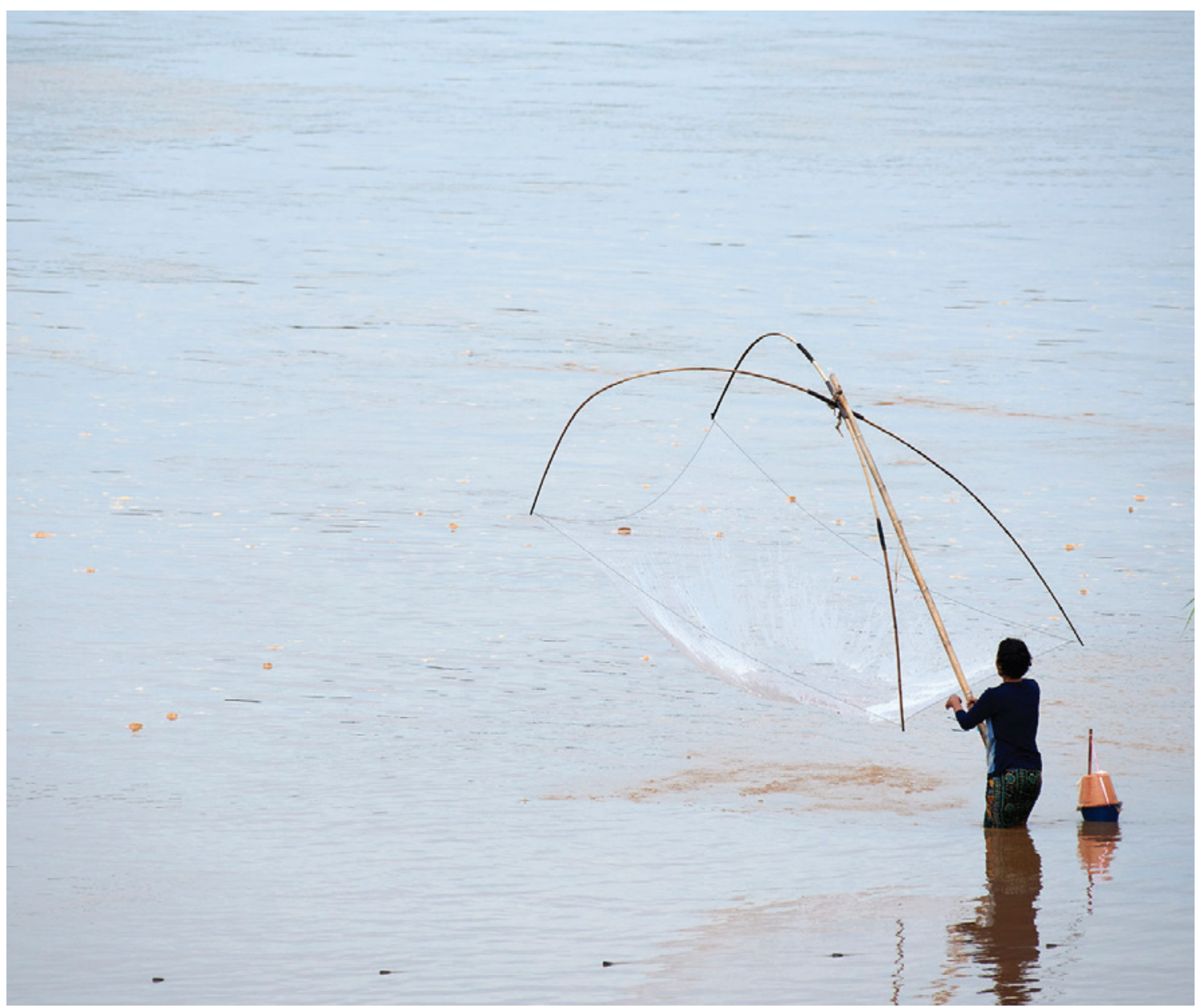




\section{REFERENCES}

Adaka, G. S., Udoh, J. P., \& Onyeukwu, D. C. (2014). Freshwater fish diversity of a tropical rainforest river in Southeast Nigeria. Advances in Life Science and Technoloy, 23(January 2014).

Ali, L., Hossain, M. A. R., \& Ahmed, M. (2009). Impact of sanctuary on fish production and biodiversity in Bangladesh (Issue August).

Anticamara, J. A., Zeller, D., \& Vincent, A. C. J. (2010). Spatial and temporal variation of abundance, biomass and diversity within marine reserves in the Philippines. Diversity and Distributions, 16(4), 529-536. https://doi.org/10.1111/j.1472-4642.2010.00661.x

Arias, M. E., Cochrane, T. A., \& Elliott, V. (2014). Modelling future changes of habitat and fauna in the Tonle Sap wetland of the Mekong. Environmental Conservation, 41(2), 165-175. https://doi.org/10.1017/S0376892913000283

Arias, M. E., Cochrane, T. A., Piman, T., Kummu, M., Caruso, B. S., \& Killeen, T. J. (2012). Quantifying changes in flooding and habitats in the Tonle Sap Lake (Cambodia) caused by water infrastructure development and climate change in the Mekong Basin. Journal of Environmental Management, 112, 53-66. https://doi.org/10.1016/j.jenvman.2012.07.003

Baran, E., Jantunen, T., \& Kieok, C. C. (2014). Values of Inland Fisheries in the Mekong River Basin (Issue January). WorldFish Center.

Beisner, B. E., Mccauley, E., \& Wrona, F. J. (1997). Predator-prey instability: Individual-level mechanisms for population-level results. Functional Ecology, 11(1), 112-120. https://doi. org/10.1046/j.1365-2435.1997.00062.x

Boyd, S. E., Limpenny, D. S., Rees, H. L., \& Cooper, K. M. (2005). The effects of marine sand and gravel extraction on the macrobenthos at a commercial dredging site (results 6 years post-dredging). ICES Journal of Marine Science, 62(2), 145-162. https://doi.org/10.1016/j. icesjms.2004.11.014

Campbell, I. C. (2009). Introduction. In I. C. Campbell (Ed.), The mekong biophysical environment of an international river basin (First). Elsevier Academic Press.

Campbell, I. C. (2012). Biodiversity of the Mekong Delta. In F. G. Renaud \& C. Künzer (Eds.), The Mekong Delta System (pp. 293-313). Springer. https://doi.org/10.1007/978-94-007-39628_11

Campbell, I. C., Say, S., \& Beardall, J. (2009). Tonle Sap Lake, the heart of the Lower Mekong. In I. C. Campbell (Ed.), The Mekong, Biophysical environment of an international river basin (pp. 251-272). Elsevier Academic Press. 
Chan, B., Ngor, P. B., So, N., \& Lek, S. (2017). Spatial and temporal changes in fish yields and fish communities in the largest tropical floodplain lake in Asia. Annales de Limnologie, 53, 485-493. https://doi.org/10.1051/limn/2017027

Chea, R., Guo, C., Grenouillet, G., \& Lek, S. (2016). Toward an ecological understanding of a floodpulse system lake in a tropical ecosystem: Food web structure and ecosystem health. Ecological Modelling, 323, 1-11. https://doi.org/10.1016/j.ecolmodel.2015.11.014

Chea, R., Lek, S., Ngor, P., \& Grenouillet, G. (2017). Large-scale patterns of fish diversity and assemblage structure in the longest tropical river in Asia. Ecology of Freshwater Fish, 26(4), 575-585. https://doi.org/10.1111/eff.12301

Chu, C., Jones, N. E., Mandrak, N. E., Piggott, A. R., \& Minns, C. K. (2008). The influence of air temperature, groundwater discharge, and climate change on the thermal diversity of stream fishes in southern Ontario watersheds. Canadian Journal of Fisheries and Aquatic Sciences, 65(2), 297-308. https://doi.org/10.1139/f08-007

Connell, J. H. (1978). Diversity in tropical rain forests and coral feefs. Science, 199(4335), 13021310. https://doi.org/10.1126/science.199.4335.1302

Cowx, I. ., Nuon, V., \& So, N. (2019). Standard sampling guidelines for fish abundance and diversity monitoring in the Lower Mekong Basin. Mekong River Commission Secretariat.

Cussac, V. E., Fernández, D. A., Gómez, S. E., \& López, H. L. (2009). Fishes of southern South America: A story driven by temperature. Fish Physiology and Biochemistry, 35(1), 29-42. https://doi.org/10.1007/s10695-008-9217-2

De Cáceres, M., \& Legendre, P. (2009). Associations between species and groups of sites: Indices and statistical inference. Ecology, 90(12), 3566-3574. https://doi.org/10.1890/08-1823.1

De Cáceres, M., Legendre, P., \& Moretti, M. (2010). Improving indicator species analysis by combining groups of sites. Oikos, 119(10), 1674-1684. https://doi.org/10.1111/j.16000706.2010.18334.x

Duan, X., Wang, Z., \& Tian, S. (2008). Effect of streambed substrate on macroinvertebrate biodiversity. Frontiers of Environmental Science and Engineering in China, 2(1), 122-128. https://doi.org/10.1007/s11783-008-0023-y

Dufrêne, M., \& Legendre, P. (1997). Species assemblages and indicator species: The need for a flexible asymmetrical approach. Ecological Monographs, 67(3), 345-366. https://doi. org/10.2307/2963459

Englmaier, G. K., Hayes, D. S., Meulenbroek, P., Terefe, Y., Lakew, A., Tesfaye, G., Waidbacher, H., Malicky, H., Wubie, A., Leitner, P., \& Graf, W. (2020). Longitudinal river zonation in the tropics: Examples of fish and caddisflies from the endorheic Awash River, Ethiopia. Hydrobiologia, 847(19), 4063-4090. https://doi.org/10.1007/s10750-020-04400-0 
Fridley, J. D. (2003). Diversity effects on production in different light and fertility environments: An experiment with communities of annual plants. Journal of Ecology, 91(3), 396-406. https://doi.org/10.1046/j.1365-2745.2003.00775.x

Grenouillet, G., Pont, D., \& Hérissé, C. (2004). Within-basin fish assemblage structure: The relative influence of habitat versus stream spatial position on local species richness. Canadian Journal of Fisheries and Aquatic Sciences, 61(1), 93-102. https://doi.org/10.1139/f03-145

Guégan, J. F., Lek, S., \& Oberdorff, T. (1998). Energy availability and habitat heterogeneity predict global riverine fish diversity. Nature, 391(6665), 382-384. https://doi.org/10.1038/34899

He, J.-S., Bazzaz, F. A., \& Schmid, B. (2002). Interactive effects of diversity, nutrients and elevated CO 2 on experimental plant communities. Oikos, 97(3), 337-348. https://doi.org/10.1034/ j.1600-0706.2002.970304.x

Hortle, K. G. (2009). Fisheries of the Mekong River Basin. In I. C. Campbell (Ed.), The Mekong, biophysical environment of an international river basin (pp. 197-249). Aquatic Ecology ed.

Hortle, K. G., \& Bamrungrach, P. (2015). Fisheries habitat and yield in the Lower Mekong Basin. Mekong River Commission Secretariat.

Howell, P., \& Simpson, D. (1994). Abundance of marine resources in relation to dissolved oxygen in Long Island Sound. Estuaries, 17(2), 394. https://doi.org/10.2307/1352672

Jongman, R. H. G., Braak, C. J. F. Ter, \& Tongeren, O. F. R. van. (1995). Data analysis in community and landscape ecology. Cambridge University Press. https://doi.org/10.1017/ CBO9780511525575

Justus, B. G., Mize, S. V., Wallace, J., \& Kroes, D. (2014). Invertebrate and fish assemblage relations to dissolved oxygen minima in lowland streams of southwestern Louisiana. River Research and Applications, 30(1), 11-28. https://doi.org/10.1002/rra.2623

Kleinhappel, T. K., Burman, O. H. P., John, E. A., Wilkinson, A., \& Pike, T. W. (2019). The impact of water $\mathrm{pH}$ on association preferences in fish. Ethology, 125(4), 195-202. https://doi. $\operatorname{org} / 10.1111 /$ eth.12843

Kong, H., Chevalier, M., Laffaille, P., \& Lek, S. (2017). Spatio-temporal variation of fish taxonomic composition in a South-East Asian flood-pulse system. PLOS ONE, 12(3), e0174582. https:// doi.org/10.1371/journal.pone.0174582

Kouamélan, E. P., Teugels, G. G., N’Douba, V., Gooré Bi, G., \& Koné, T. (2003). Fish diversity and its relationships with environmental variables in a West African basin. Hydrobiologia, 505(13), 139-146. https://doi.org/10.1023/B:HYDR.0000007302.74296.84

Lambshead, P. J. D., Platt, H. M., \& Shaw, K. M. (1983). The detection of differences among assemblages of marine benthic species based on an assessment of dominance and diversity. Journal of Natural History, 17(6), 859-874. https://doi.org/10.1080/00222938300770671 
Lasne, E., Bergerot, B., Lek, S., \& Laffaille, P. (2007). Fish zonation and indicator species for the evaluation of the ecological status of rivers: Example of the Loire basin (France). River Research and Applications, 23(8), 877-890. https://doi.org/10.1002/rra.1030

Legendre, P., \& De Cáceres, M. (2013). Beta diversity as the variance of community data: Dissimilarity coefficients and partitioning. Ecology Letters, 16(8), 951-963. https://doi. org/10.1111/ele.12141

Legendre, P., \& Legendre, L. (2012). Numerical Ecology (3rd ed.). Elsevier BV.

Legendre, P., \& Salvat, B. (2015). Thirty-year recovery of mollusc communities after nuclear experimentations on Fangataufa atoll (Tuamotu, French Polynesia). Proceedings of the Royal Society B: Biological Sciences, 282(1810). https://doi.org/10.1098/rspb.2015.0750

Leuven, R. S. E. W., Hendriks, A. J., Huijbregts, M. A. J., Lenders, H. J. R., Matthews, J., \& Velde, G. Van Der. (2011). Differences in sensitivity of native and exotic fish species to changes in river temperature. Current Zoology, 57(6), 852-862. https://doi.org/10.1093/czoolo/57.6.852

Lima-Junior, S. E., Cardone, I. B., \& Goitein, R. (2006). Fish assemblage structure and aquatic pollution in a Brazilian stream: Some limitations of diversity indices and models for environmental impact studies. Ecology of Freshwater Fish, 15(3), 284-290. https://doi. org/10.1111/j.1600-0633.2006.00156.x

Magurran, A. (2004). Measuring biologcial diversity. In Blackwell Publishing. Blackwell Science Ltd.

Mekong River Commission. (2011). Planning atlas of the Lower Mekong River Basin. In Mekong River Commission. Mekong River Commission Secretariat. http://www.mrcmekong.org/ assets/Publications/basin-reports/BDP-Atlas-Final-2011.pdf

Mekong River Commission. (2013). Integrated analysis of data from MRC fisheries monitoring programmes in the Lower Mekong Basin. Mekong River Commission Secretariat.

Mekong River Commission. (2015). Climate change impacts on hydrology of the Lower Mekong Basin-Volume 1: Water level, flow and salinity. Mekong River Commission Secretariat.

Mekong River Commission. (2017). The Council study: The study on sustainable management and development of the Mekong River, including impacts of mainstream hydropower projects. biological resource assessment final technical report series. Volume 1: Specialists' report (Vol. 1, Issue September). Mekong River Commission Secretariat.

Mekong River Commission. (2018a). MRC's updated database offers comprehensive information on Mekong fish species. http://www.mrcmekong.org/news-and-events/events/mrcupdated-database-offers-comprehensive-information-on-mekong-fish-species/

Mekong River Commission. (2018b). State of the basin report 2018. In Mekong River Commission. Mekong River Commission Secretariat. https://doi.org/ISSN 1728:3248 
Mount, D. I. (1973). Chronic effect of low pH on fathead minnow survival, growth and reproduction. Water Research, 7(7), 987-993. https://doi.org/10.1016/0043-1354(73)90180-2

Ngor, P. B., Grenouillet, G., Phem, S., So, N., \& Lek, S. (2018). Spatial and temporal variation in fish community structure and diversity in the largest tropical flood-pulse system of South-East Asia. Ecology of Freshwater Fish, 27, 1087-1100. https://doi.org/10.1111/eff.12417

Ngor, P. B., Legendre, P., Oberdorff, T., \& Lek, S. (2018). Flow alterations by dams shaped fish assemblage dynamics in the complex Mekong-3S river system. Ecological Indicators, 88(July 2017), 103-114. https://doi.org/10.1016/j.ecolind.2018.01.023

Ngor, P. B., McCann, K. S., Grenouillet, G., So, N., McMeans, B. C., Fraser, E., \& Lek, S. (2018). Evidence of indiscriminate fishing effects in one of the world's largest inland fisheries. Scientific Reports, 8(1), 1-12. https://doi.org/10.1038/s41598-018-27340-1

Ngor, P. B., Oberdorff, T., Phen, C., Baehr, C., Grenouillet, G., \& Lek, S. (2018). Fish assemblage responses to flow seasonality and predictability in a tropical flood pulse system. Ecosphere, 9(11), e02366. https://doi.org/10.1002/ecs2.2366

Nuon, V., Lek, S., Ngor, P. B., So, N., \& Grenouillet, G. (2020). Fish community responses to humaninduced stresses in the Lower Mekong Basin. Water (Switzerland), 12(12), 1-21. https:// doi.org/10.3390/w12123522

Parmesan, C., \& Yohe, G. (2003). A globally coherent fingerprint of climate change impacts across natural systems. Nature, 421(6918), 37-42. https://doi.org/10.1038/nature01286

Pitchaiah, P. S. (2017). Impacts of Sand Mining on Environment-A Review. International Journal of Geoinformatics and Geological Science, 4(1), 1-6. https://doi.org/10.14445/23939206/ ijggs-v4i1p101

Poff, N. L., \& Allan, J. D. (1995). Functional organization of stream fish assemblages in relation to hydrological variability. Ecology, 76(2), 606-627. https://doi.org/10.2307/1941217

Pool, T., Elliott, V., Holtgrieve, G., Arias, M., Altman, I., Kaufman, L., McCann, K., Fraser, E. D. G., Tudesque, L., Chevalier, M., Grenouillet, G., Chea, R., Lek, S., McMeans, B., Cooperman, M., Phen, C., Hannah, L., Miller, B., Guo, C., \& Nam, S. (2019). Fish assemblage composition within the floodplain habitat mosaic of a tropical lake (Tonle Sap, Cambodia). Freshwater Biology, 64(11), 2026-2036. https://doi.org/10.1111/fwb.13391

Rask, M. (1984). The effect of low pH on perch, Perca fluviatilis L. II. The effect of acid stress on different development stages of perch. In Annales Zoologici Fennici (Vol. 21, Issue 1, pp. 9-13).

Rocha, R., Thomaz, S., Carvalho, P., \& Gomes, L. (2009). Modeling chlorophyll-a and dissolved oxygen concentration in tropical floodplain lakes (Paraná River , Brazil). Brazilian Journal of Biology, 69(2 suppl), 491-500. https://doi.org/10.1590/S1519-69842009000300005 
Shaw, K., Lambshead, P., \& Piatt, H. (1983). Detection of pollution-induced disturbance in marine benthic assemblages with special reference to nematodes. Marine Ecology Progress Series, 11, 195-202. https://doi.org/10.3354/meps011195

So, N., Phommakone, S., Ly, V., Samphawamana, T., Nguyen, H. S., Khumsri, M., Ngor, P. B., Kong, S., Degen, P., \& Starr, P. (2015). Lower Mekong fisheries estimated to be worth around \$17 billion a year. Catch and Culture, 21(3), 4-7. http://www.mrcmekong.org/assets/ Publications/Catch-and-Culture/CatchCultureVol-21.3.pdf

Stone, R. (2016). Dam-building threatens Mekong fisheries. Science, 354(6316), 1084-1085. https://doi.org/10.1126/science.354.6316.1084

Sutherst, R. W. (2000). Climate change and invasive species: A conceptual framework. In H. Mooney \& R. J. Hobbs (Eds.), Invasive species in a changing world (p. 384). Island Press.

Thomas, C. D., Cameron, A., Green, R. E., Bakkenes, M., Beaumont, L. J., Collingham, Y. C., Erasmus, B. F. N., de Siqueira, M. F., Grainger, A., Hannah, L., Hughes, L., Huntley, B., van Jaarsveld, A. S., Midgley, G. F., Miles, L., Ortega-Huerta, M. A., Townsend Peterson, A., Phillips, O. L., \& Williams, S. E. (2004). Extinction risk from climate change. Nature, 427(6970), 145-148. https://doi.org/10.1038/nature02121

Valbo-Jorgensen, J., Coates, D., \& Hortle, K. G. (2009). Fish diversity in the Mekong River Basin. In C. I. Cambel (Ed.), The Mekong biophysical environment of an international river basin (pp. 162-185). Elsevier Academic Press.

Warwick, R. M. (1986). A new method for detecting pollution effects on marine macrobenthic communities. Marine Biology, 92(4), 557-562. https://doi.org/10.1007/BF00392515

Wenger, A. S., Harvey, E., Wilson, S., Rawson, C., Newman, S. J., Clarke, D., Saunders, B. J., Browne, N., Travers, M. J., Mcilwain, J. L., Erftemeijer, P. L. A., Hobbs, J. P. A., Mclean, D., Depczynski, M., \& Evans, R. D. (2017). A critical analysis of the direct effects of dredging on fish. Fish and Fisheries, 18(5), 967-985. https://doi.org/10.1111/faf.12218

Whittaker, R. H. (1965). Dominance and diversity in land plant communities: Numerical relations of species express the importance of competition in community function and evolution. Science, 147(3655), 250-260. https://doi.org/10.1126/science.147.3655.250

Winemiller, K. O., McIntyre, P. B., Castello, L., Fluet-Chouinard, E., Giarrizzo, T., Nam, S., Baird, I. G., Darwall, W., Lujan, N. K., Harrison, I., Stiassny, M. L. J., Silvano, R. A. M., Fitzgerald, D. B., Pelicice, F. M., Agostinho, A. A., Gomes, L. C., Albert, J. S., Baran, E., Petrere, M., ... Sáenz, L. (2016). Balancing hydropower and biodiversity in the Amazon, Congo, and Mekong. Science, 351(6269), 128-129. https://doi.org/10.1126/science.aac7082

WWF. (2013). Ecosystems in the Greater Mekong: Past trends, current trends, possible futures. WWF-Great Mekong. 
Annex 1: Sampling Station Characteristics

\begin{tabular}{|c|c|c|c|c|c|c|c|c|c|}
\hline No. & Country & Province & District & Village & $\begin{array}{l}\text { Site } \\
\text { Code }\end{array}$ & $\begin{array}{l}\text { Used for } \\
\text { this study }\end{array}$ & Habitats & $\begin{array}{l}\text { BioRA } \\
\text { Zone }\end{array}$ & Station Characteristics \\
\hline 1 & Cambodia & Battambang & Ek Phnom & Prek Torl & CBT & $x$ & $\begin{array}{l}\text { Tonle Sap } \\
\text { Floodplain }\end{array}$ & Zone 7 & $\begin{array}{l}\text { This station is located in the northwest of Tonle Sap Great } \\
\text { Lake and near Prek Toal biospheres. In the dry season } \\
\text { between December to May, fishers can catch more fish. The } \\
\text { main fishing habitats in this station are Tonle Sap Great Lake, } \\
\text { flooded forest, and Sangke River. }\end{array}$ \\
\hline 2 & Cambodia & $\begin{array}{l}\text { Kompong } \\
\text { Chhnang }\end{array}$ & Boribo & Chhnouk Trou & CKC & $x$ & $\begin{array}{l}\text { Tonle Sap } \\
\text { Floodplain }\end{array}$ & Zone 7 & $\begin{array}{l}\text { This station is located in a lowland floodplain in the central } \\
\text { part of Tonle Sap with lots of tributaries. The water flows in } \\
\text { and out of the Tonle Sap Lake so the fishers have difficulty } \\
\text { using fishing nets. The main fishing habitats are Tonle Sap } \\
\text { River and flooded forest. }\end{array}$ \\
\hline 3 & Cambodia & Kompong Thom & Kompong Svay & $\begin{array}{l}\text { Neang Sav; } \\
\text { Pheam Bang; } \\
\text { Pich Chikreng }\end{array}$ & CPT & $x$ & $\begin{array}{l}\text { Tonle Sap } \\
\text { Floodplain }\end{array}$ & Zone 7 & $\begin{array}{l}\text { This station is located between Tonle Sap Lake and } \\
\text { the Tonle Chhmar Ramsar site. This station is rich in flooded } \\
\text { forest and water hyacine from the Staung River. The main } \\
\text { habitats are Tonle Sap lake, flooded forest, and Staung River. }\end{array}$ \\
\hline 4 & Cambodia & Pursat & Kro Kor & Ti $1,3,4$ & CPS & $x$ & $\begin{array}{l}\text { Tonle Sap } \\
\text { Floodplain }\end{array}$ & Zone 7 & $\begin{array}{l}\text { This station is located in Kompong Loung Commune } \\
\text { near two fisheries conservation areas. There are lots of } \\
\text { fishing grounds. The main habitats are Tonle Sap Lake and } \\
\text { flooded forest. }\end{array}$ \\
\hline 5 & Cambodia & Siem Reap & Siem Reap & Ti $3,4,5$ & CSR & $x$ & $\begin{array}{l}\text { Tonle Sap } \\
\text { Floodplain }\end{array}$ & Zone 7 & $\begin{array}{l}\text { This station is located in Kompong Phluk Commune. } \\
\text { It is a good habitat for fish because it is rich in flooded forest. } \\
\text { The main habitats are Tonle Sap Great lake and flooded } \\
\text { forest. }\end{array}$ \\
\hline 6 & Cambodia & Kra Tie & Sambo & Koh Khne & CKT & $x$ & $\begin{array}{l}\text { Mekong } \\
\text { mainstream }\end{array}$ & Zone 4 & $\begin{array}{l}\text { This station is located in the Mekong mainstream and is } \\
\text { surrounded by many islands. It has a lot of deep pools and } \\
\text { areas of rapids. It is home to many fish species in the dry } \\
\text { season. The fishing habitats are the Mekong River and Canal. }\end{array}$ \\
\hline 7 & Cambodia & Kandal & Ponhea Leu & Sang Var & CKD & $x$ & Tributaries & Zone 7 & $\begin{array}{l}\text { This station is located on the Tonle Sap River and is different } \\
\text { from other stations. The main fishing habitat is the Tonle Sap } \\
\text { River. }\end{array}$ \\
\hline
\end{tabular}




\begin{tabular}{|c|c|c|c|c|c|c|c|c|c|}
\hline No. & Country & Province & District & Village & $\begin{array}{l}\text { Site } \\
\text { Code }\end{array}$ & $\begin{array}{l}\text { Used for } \\
\text { this study }\end{array}$ & Habitats & $\begin{array}{l}\text { BioRA } \\
\text { Zone }\end{array}$ & Station Characteristics \\
\hline 8 & Cambodia & Ratanakiri & Veounsai & Fang & CSS & $x$ & Tributaries & Zone 3S & $\begin{array}{l}\text { This station is located in the Sesan River and experiences } \\
\text { a lot of impacts from dam construction. The water level in } \\
\text { this area does not changes according to the seasons. The } \\
\text { riverbed has a lot of sand brought by strong currents from } \\
\text { the dam and has become shallow. In the dry season, people } \\
\text { can walk across the river. There are five main fishing habitats } \\
\text { in this station: the Sesan River, canal, lake, pond, and rice } \\
\text { fields. }\end{array}$ \\
\hline 9 & Cambodia & Ratanakiri & Lum Phat & Day Lo & CSP & $x$ & Tributaries & Zone 35 & $\begin{array}{l}\text { This station is located in the Srepork River. There are many } \\
\text { impacts from dam construction in the upper part of the } \\
\text { stream causing water in the river to change every day. This } \\
\text { station has small pools and an area of rapids. The fishing } \\
\text { habitats are the Srepork River and canal. }\end{array}$ \\
\hline 10 & Cambodia & Stung Treng & Siem Pang & Pres Bang & CSK & $x$ & Tributaries & Zone 3S & $\begin{array}{l}\text { This station is located in the Sekong River in Siam Pang } \\
\text { district. The river connects to the Mekong River at Stung } \\
\text { Treng town. There are a lot of pools, areas of rapids, and } \\
\text { it has one spawning habitat of Probabus sp. on Koh Tachan } \\
\text { island. The fishing habitats in this area are the Sekong River, } \\
\text { canal, flooded area, pond, and rice fields. }\end{array}$ \\
\hline 11 & Cambodia & Stung Treng & Thalaborivat & Ou Run & CST & $x$ & $\begin{array}{l}\text { Mekong } \\
\text { mainstream }\end{array}$ & Zone 4 & $\begin{array}{l}\text { This station has a lot of flooded forests, deep pools, and } \\
\text { areas of rapids. It is home to many fish species in the dry } \\
\text { season, especially the large-sized fish. The fishing habitats } \\
\text { are the Mekong River and canal. }\end{array}$ \\
\hline 12 & Lao PDR & Attapeu & Samakhixay & Saphaothong & LAP & & Tributaries & $\mathrm{N} / \mathrm{A}$ & $\begin{array}{l}\text { The fishing ground is located in the Xekong River. The area } \\
\text { is near a deep pool with an average depth 7-10 m during } \\
\text { the dry season. Water flow is slow and the bottom of river } \\
\text { consists of rocks and sand. There are gardens and houses } \\
\text { along the riverbank. }\end{array}$ \\
\hline 13 & Lao PDR & Borikhamxay & Pak sanh & Sinhxay & LBX & $x$ & $\begin{array}{l}\text { Mekong } \\
\text { mainstream }\end{array}$ & Zone 3 & $\begin{array}{l}\text { The fishing ground is about } 500 \mathrm{~m} \text { from the village, at the } \\
\text { confluence of the Ngip River with the Mekong River. The } \\
\text { water flow is slow and the bottom is sandy with muddy with } \\
\text { a depth is } 12 \mathrm{~m} \text {. The riverbanks are surrounded by gardens } \\
\text { and houses. }\end{array}$ \\
\hline
\end{tabular}




\begin{tabular}{|c|c|c|c|c|c|c|c|c|c|}
\hline No. & Country & Province & District & Village & $\begin{array}{l}\text { Site } \\
\text { Code }\end{array}$ & $\begin{array}{l}\text { Used for } \\
\text { this study }\end{array}$ & Habitats & $\begin{array}{l}\text { BioRA } \\
\text { Zone }\end{array}$ & Station Characteristics \\
\hline 14 & Lao PDR & Borkeo & Huay xai & Huay tap & LHT & & $\begin{array}{l}\text { Mekong } \\
\text { mainstream }\end{array}$ & Zone 1 & $\begin{array}{l}\text { This fishing ground is around } 25 \mathrm{~km} \text { from the village, and has } \\
\text { a water flow that is fast with a bottom of sand and rocks. The } \\
\text { water depth is } 15-20 \mathrm{~m} \text {. There is a deep pool near the fishing } \\
\text { areas with a depth of } 40 \mathrm{~m} \text {. }\end{array}$ \\
\hline 15 & Lao PDR & Borkeo & Huay xai & Donekoun & LDK & & Tributaries & Zone 1 & $\begin{array}{l}\text { The fishing area is about } 3 \mathrm{~km} \text { from the village. The water } \\
\text { flow is moderate and the bottom consists of sand and rocks. } \\
\text { The water depth is } 8-10 \mathrm{~m} \text {, and the riverbank is surrounded } \\
\text { by forest and gardens. }\end{array}$ \\
\hline 16 & Lao PDR & Champasak & Khong & Hangsadam & LSD & & $\begin{array}{l}\text { Mekong } \\
\text { mainstream }\end{array}$ & Zone 4 & $\begin{array}{l}\text { The fishing areas is about } 300 \mathrm{~m} \text { from the village. The water } \\
\text { flow is slow and the bottom consists of sand and rocks. The } \\
\text { water depth is } 15 \mathrm{~m} \text { and the riverbank is surrounded by } \\
\text { forest. }\end{array}$ \\
\hline 17 & Lao PDR & Champasak & Khong & Hat & LCS & & $\begin{array}{l}\text { Mekong } \\
\text { mainstream }\end{array}$ & Zone 4 & $\begin{array}{l}\text { The fishing areas is } 800 \mathrm{~m} \text { from the village and the water } \\
\text { flow is moderate. The water depth is about } 18 \mathrm{~m} \text { and the } \\
\text { bottom consists of sand and rocks. This is known as a fish } \\
\text { migration corridor for cyprinid species in the dry season } \\
\text { during Chinese New Year. }\end{array}$ \\
\hline 18 & Lao PDR & Champasak & Phonthong & Hatsalao & LSL & & $\begin{array}{l}\text { Mekong } \\
\text { mainstream }\end{array}$ & Zone 4 & $\begin{array}{l}\text { This fishing areas is closed to the village and the riverbank } \\
\text { is surrounded by banana gardens. The water depth is about } \\
25-30 \mathrm{~m} \text {. The water flow is moderate with mud and sand on } \\
\text { the river bottom. There are } 25 \text { fishers working in this area. }\end{array}$ \\
\hline 19 & Lao PDR & Luangphrabang & Luangphrabang & Pha O & LPB & $x$ & $\begin{array}{l}\text { Mekong } \\
\text { mainstream }\end{array}$ & Zone 2 & $\begin{array}{l}\text { The fishing areas is located in the mainstream and about } 1 \\
\mathrm{~km} \text { from the village. The water depth is } 15 \mathrm{~m} \text { and the bottom } \\
\text { consists of sand and rocks. The water flow is moderate. } \\
\text { About } 15 \text { fishers work in this area. }\end{array}$ \\
\hline 20 & Lao PDR & Luangphrabang & Pak Ou & Hadgna & LPO & $x$ & Tributaries & Zone 2 & $\begin{array}{l}\text { This fishing areas is located in the Ou River about } 2-4 \\
\mathrm{~km} \text { from the village. The water depth is about } 9 \mathrm{~m} \text { and } \\
\text { the bottom consists of sand and rocks. The water flow is } \\
\text { moderate and the riverbank is surrounded by gardens and } \\
\text { houses. The area is located about } 10 \mathrm{~km} \text { downstream of the } \\
\text { Nam Ou dam. Ten fishers are working in this area. }\end{array}$ \\
\hline
\end{tabular}




\begin{tabular}{|c|c|c|c|c|c|c|c|c|c|}
\hline No. & Country & Province & District & Village & $\begin{array}{l}\text { Site } \\
\text { Code }\end{array}$ & $\begin{array}{l}\text { Used for } \\
\text { this study }\end{array}$ & Habitats & $\begin{array}{l}\text { BioRA } \\
\text { Zone }\end{array}$ & Station Characteristics \\
\hline 21 & Lao PDR & Oudomxay & Pak beng & Pak ngery & LPN & & $\begin{array}{l}\text { Mekong } \\
\text { mainstream }\end{array}$ & Zone 1 & $\begin{array}{l}\text { This fishing areas is located in the mainstream about } 1 \mathrm{~km} \\
\text { from the village. The water depth is } 60 \mathrm{~m} \text {, the river bottom } \\
\text { is rocky, and it has a moderate flow. The river bank is } \\
\text { surrounded by forest. }\end{array}$ \\
\hline 22 & Lao PDR & Oudomxay & Pak beng & Pakbeng & LOX & & Tributaries & Zone 1 & $\begin{array}{l}\text { The fishing areas are about } 3 \mathrm{~km} \text { from the village. The water } \\
\text { depth is about } 4 \mathrm{~m} \text {. The river bottom is mixed with rock and } \\
\text { mud, and it has a moderate water flow. The riverbank is } \\
\text { surrounded by forest and gardens. It is located about } 2 \mathrm{~km} \\
\text { from Pak Beng dam. }\end{array}$ \\
\hline 23 & Lao PDR & Vientiane Capital & Hatxayfong & Thamuang & LVT & $x$ & $\begin{array}{l}\text { Mekong } \\
\text { mainstream }\end{array}$ & Zone 3 & $\begin{array}{l}\text { This fishing area is about } 500 \mathrm{~m} \text { from the village. The water } \\
\text { depth is } 12 \mathrm{~m} \text { and the bottom consists of sand and rocks. The } \\
\text { water flow is fast. The riverbank is surrounded by houses. } \\
\text { About } 20 \text { fishers are fishing in this area. }\end{array}$ \\
\hline 24 & Lao PDR & Xayaboury & Xayaboury & Thadeua & LXB & & $\begin{array}{l}\text { Mekong } \\
\text { mainstream }\end{array}$ & Zone 2 & $\begin{array}{l}\text { This fishing area is about } 3 \mathrm{~km} \text { from the village. The water } \\
\text { depth is } 30 \mathrm{~m} \text { and the river bottom is rocky and muddy. It } \\
\text { has a moderate flow. The riverbank is surrounded by forest. } \\
\text { About } 15-20 \text { fishers are fishing in this area. This area is } \\
\text { located downstream of the Xayaboury dam. }\end{array}$ \\
\hline 25 & Lao PDR & Xayaboury & Xayaboury & Na xam & LNS & & Tributaries & Zone 2 & $\begin{array}{l}\text { This fishing area is located in Nam Houng about } 2 \mathrm{~km} \text { from } \\
\text { the village. The water depth is } 6 \mathrm{~m} \text {, it has a fast flow, and } \\
\text { the bottom consists of sand and rocks. The riverbank is } \\
\text { surrounded by forest and gardens. About } 10 \text { fishers are } \\
\text { fishing in this area. }\end{array}$ \\
\hline 26 & Lao PDR & Xekong & Lamam & Navasaen & LXK & & Tributaries & N/A & $\begin{array}{l}\text { This fishing area is located in Xekong River about } 500 \mathrm{~m} \text { from } \\
\text { the village. The water depth is } 15 \mathrm{~m} \text { and the bottom consists } \\
\text { of sand and rocks. The water flow is slow and the riverbank } \\
\text { is surrounded by gardens. }\end{array}$ \\
\hline 27 & Thailand & Loei & Chiangkhan & Ban Noy & TCK & $x$ & $\begin{array}{l}\text { Mekong } \\
\text { mainstream }\end{array}$ & Zone 2 & $\begin{array}{l}\text { This station is narrower than the other stations and there is a } \\
\text { rocky barrier in the middle of the mainstream, so the water } \\
\text { current is quite strong. There are } 40-50 \text { fishers working } \\
\text { along the river in this area. }\end{array}$ \\
\hline
\end{tabular}




\begin{tabular}{|c|c|c|c|c|c|c|c|c|c|}
\hline No. & Country & Province & District & Village & $\begin{array}{l}\text { Site } \\
\text { Code }\end{array}$ & $\begin{array}{l}\text { Used for } \\
\text { this study }\end{array}$ & Habitats & $\begin{array}{l}\text { BioRA } \\
\text { Zone }\end{array}$ & Station Characteristics \\
\hline 28 & Thailand & Nakhon Phanom & Si Songkhram & Ban Tha Bho & TSK & $x$ & Floodplain & Zone 3 & $\begin{array}{l}\text { The station has many floodplain areas and many swamps } \\
\text { around it. There are many tributaries and its water flows to } \\
\text { the Songkhram mainstream, such as Huai Hee, Nam Mao, } \\
\text { and Nam Yam etc. There are also a lot of fishing grounds in } \\
\text { the Lower Songkhram Basin. }\end{array}$ \\
\hline 29 & Thailand & Nakhonphanom & Tha Uthen & $\begin{array}{l}\text { Ban Tha Dok } \\
\text { Kaeo }\end{array}$ & TUT & $\mathrm{x}$ & $\begin{array}{l}\text { Mekong } \\
\text { mainstream }\end{array}$ & Zone 3 & $\begin{array}{l}\text { It is wider than the others areas. The water current is slow. } \\
\text { There are about } 15 \text { fishers fishing in this village. }\end{array}$ \\
\hline 30 & Thailand & Nong Khai & Tha Bo & Thadaeng & TNK & $\mathrm{x}$ & Tributaries & Zone 2 & $\begin{array}{l}\text { This station is located at a tributary and has a development } \\
\text { project for irrigation and flood protection. There is a weir at } \\
\text { the mouth of the Huai Mong River near the Mekong River, } \\
\text { and there are } 9 \text { pumping stations and irrigation canals. } \\
\text { After construction of the weir, the flood area in Huai Mong } \\
\text { decreased and became rice fields and an agricultural area. }\end{array}$ \\
\hline 31 & Thailand & Ubon Ratchathani & Khemarat & Ladjalean & TKR & $\mathrm{x}$ & $\begin{array}{l}\text { Mekong } \\
\text { mainstream }\end{array}$ & Zone 3 & $\begin{array}{l}\text { There are two deep pools in this station where fishers catch } \\
\text { fish, one is Wern Kan Yang and the other is Wern Mae Kai } \\
\text { Fuk. Wern Kan Yang has the strongest water current and } \\
\text { deepest water level. There are } 17-20 \text { fishers catching fish } \\
\text { in this area. }\end{array}$ \\
\hline 32 & Viet Nam & An Giang & An Phu & Ap 2 & VAP & $x$ & Canal & Zone 8 & $\begin{array}{l}\text { This station is a branch of the Bassac River near a natural } \\
\text { reservoir. it is used for aquaculture and tourism. The strong } \\
\text { current is on a downward tidal regime. There are about } 30 \\
\text { fishers in this area. }\end{array}$ \\
\hline 33 & Viet Nam & An Giang & Cho Moi & My Thuan & VCM & $\mathrm{x}$ & $\begin{array}{l}\text { Mekong } \\
\text { mainstream }\end{array}$ & Zone 8 & $\begin{array}{l}\text { This station is a big canal connecting the Mekong and Bassac } \\
\text { rivers. It is about } 7 \mathrm{~km} \text { long and } 500 \mathrm{~m} \text { wide. The main } \\
\text { shipway is used as an international trade shipway. There is } \\
\text { one deep pool at the corner about } 50 \mathrm{~m} \text { deep. The strong } \\
\text { current is on a downward tidal regime. There are about } 50 \\
\text { fishers in this area. }\end{array}$ \\
\hline 34 & Viet Nam & An Giang & Thoai Son & Tay Son & VTS & $x$ & $\begin{array}{l}\text { Floodplain/ } \\
\text { swamp }\end{array}$ & Zone 8 & $\begin{array}{l}\text { This station is in a flood land area but fishers catch fish } \\
\text { in the tributary/canal because there are rice field dykes } \\
\text { for irrigation. The current is not strong in the upward or } \\
\text { downward tidal regime. There are } 15-20 \text { fishers in this area. }\end{array}$ \\
\hline
\end{tabular}




\begin{tabular}{|c|c|c|c|c|c|c|c|c|c|}
\hline No. & Country & Province & District & Village & $\begin{array}{l}\text { Site } \\
\text { Code }\end{array}$ & $\begin{array}{l}\text { Used for } \\
\text { this study }\end{array}$ & Habitats & $\begin{array}{l}\text { BioRA } \\
\text { Zone }\end{array}$ & Station Characteristics \\
\hline 35 & Viet Nam & Can Tho & Phong Dien & My Thuan & VCT & & $\begin{array}{l}\text { Floodplain/ } \\
\text { swamp }\end{array}$ & Zone 8 & $\begin{array}{l}\text { This station is in a flooded area, but fishers catch fish in the } \\
\text { tributary/canal of the Bassac River. The water current is not } \\
\text { strong in the upward or downward tidal regime. There are } \\
10-15 \text { fishers in this area. }\end{array}$ \\
\hline 36 & Viet Nam & Tra Vinh & Tieu Can & Khom 3 & VTV & $x$ & Estuarine & Zone 8 & $\begin{array}{l}\text { This station is located on the Bassac mainstream, near the } \\
\text { estuary. It sees } 3 \text { months of freshwater (in the flood season) } \\
\text { and } 9 \text { months of salt water. The water current depends on } \\
\text { the tidal regime; it isn't strong when the tide comes in but } \\
\text { is strong when the tide goes out. There are } 15-20 \text { fishers in } \\
\text { this area. }\end{array}$ \\
\hline 37 & Viet Nam & Tra Vinh & TP Tra Vinh & Long Tri & VLT & & Estuarine & Zone 8 & $\begin{array}{l}\text { This station is located on the Mekong mainstream, near the } \\
\text { estuary. It sees } 3 \text { months of freshwater (in the flood season) } \\
\text { and } 9 \text { months of salt water. The water current depends on } \\
\text { the tidal regime; it isn't strong when the tide comes in but } \\
\text { is strong when the tide goes out. There are } 15-20 \text { fishers in } \\
\text { this area. }\end{array}$ \\
\hline 38 & Viet Nam & Vinh Long & Vung Liem & Lang & VVL & $x$ & $\begin{array}{l}\text { Mekong } \\
\text { mainstream }\end{array}$ & Zone 8 & $\begin{array}{l}\text { This station is located on the Mekong mainstream with some } \\
\text { islands around it. In the river, there are some sand mining } \\
\text { activities. So, the water is not transparent and the current } \\
\text { depends on the tidal regime; it isn't so strong when the tide } \\
\text { comes in but is strong when the tide goes out. There are } \\
12-15 \text { fishers catching fish in this area. }\end{array}$ \\
\hline
\end{tabular}




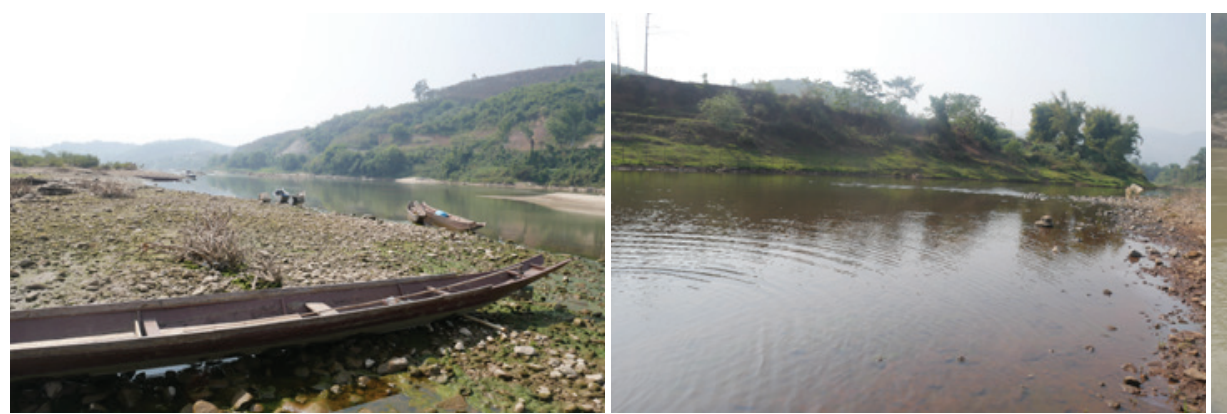

LHT, Mainstream at Borkeo province

LDK, Tributary at Borkeo province

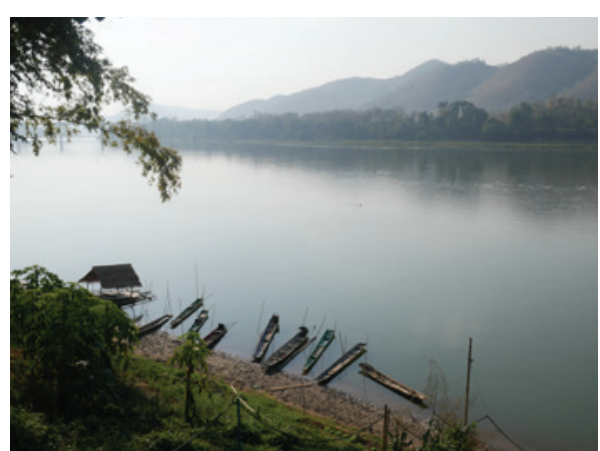

LPB, Mainstream at Luangphrabang province

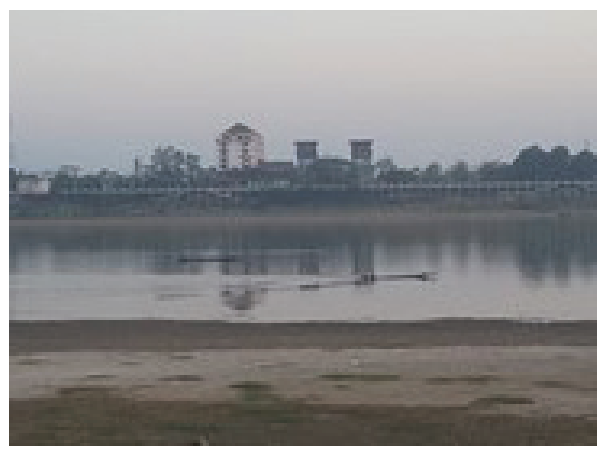

LVT, Mainstream at Vientiane Capital

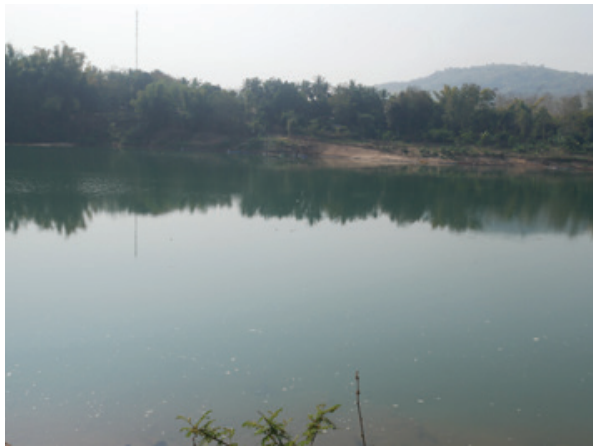

LPO, Tributary at Luangphrabang province

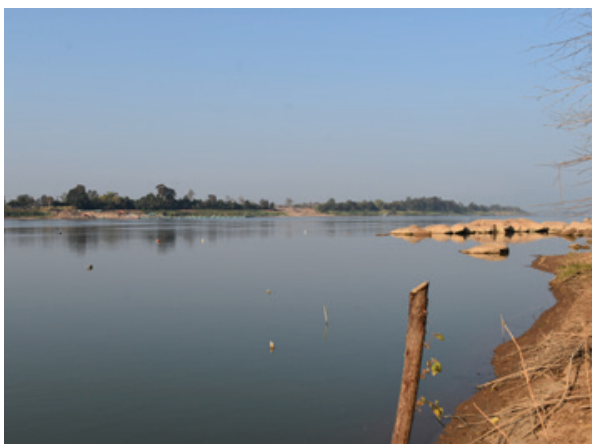

LBX, Mean stream at Borikhamxay province

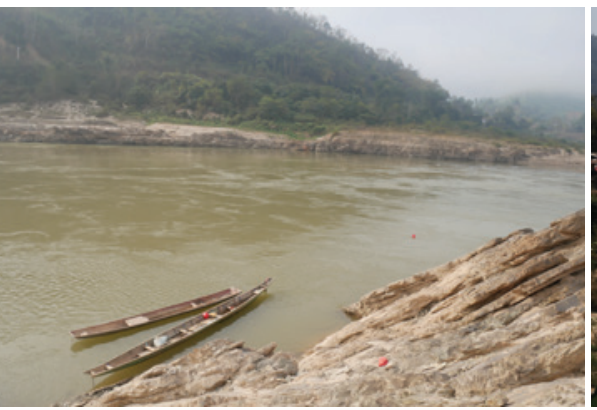

LPN, Mainstream at Oudomxay province

LOX, Tributary at Oudomxay province

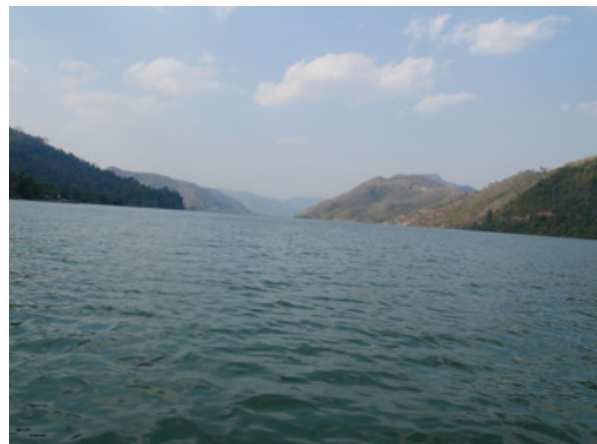

LXB, Mainstream at Xayaboury province

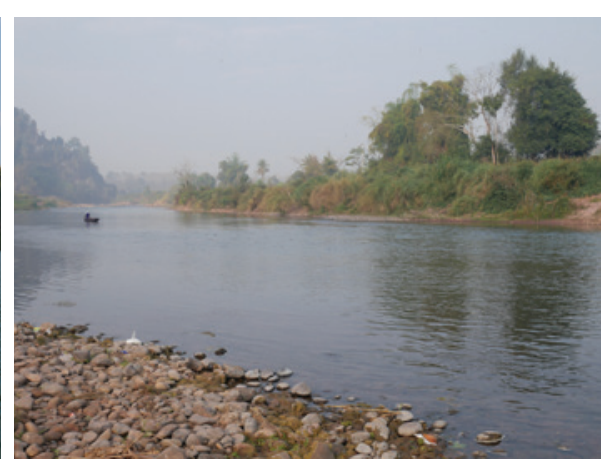

LNS, Tributary at Xayaboury province

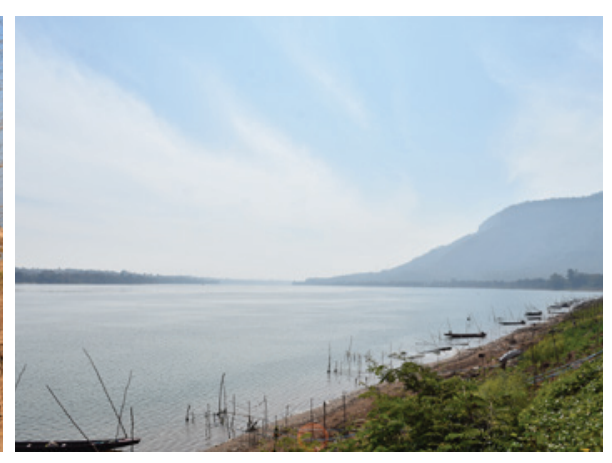

LSL, Mean stream at Champasak province

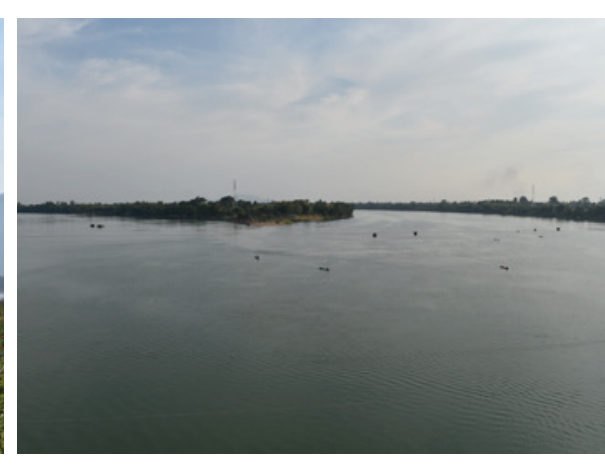

LCS, Mainstream at Champasak province 


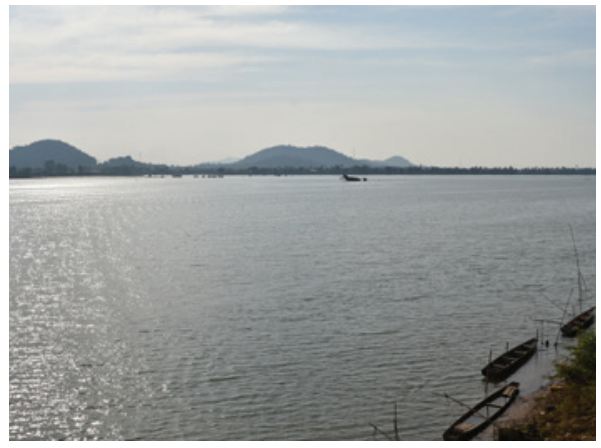

LSD, Mainstream at Champasak province

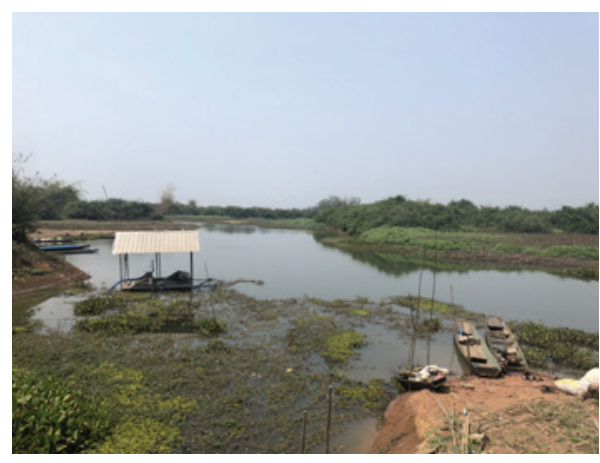

TNK, Tributary at Nong Khai province

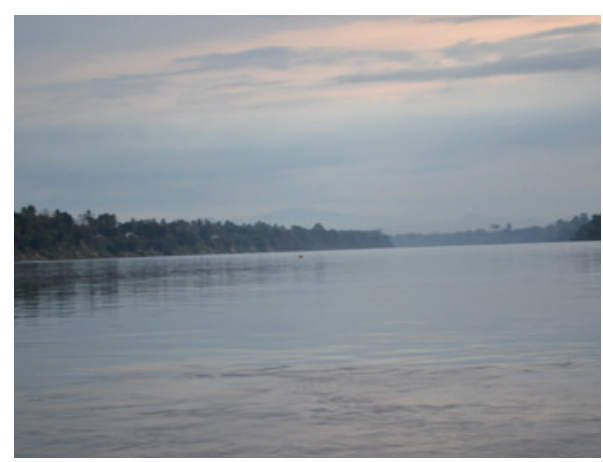

CSK, Sekong at Stung Treng province

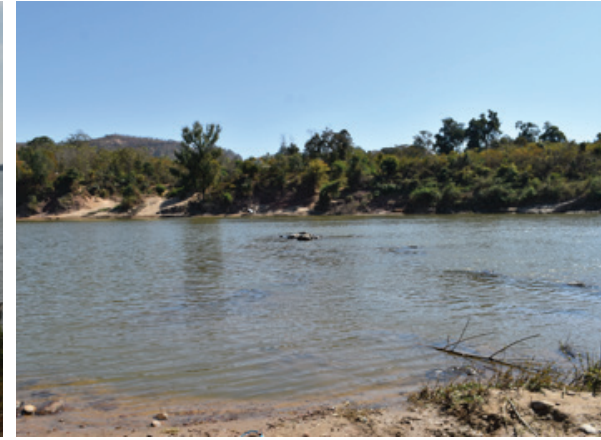

LXK, Tributary at Xekong province

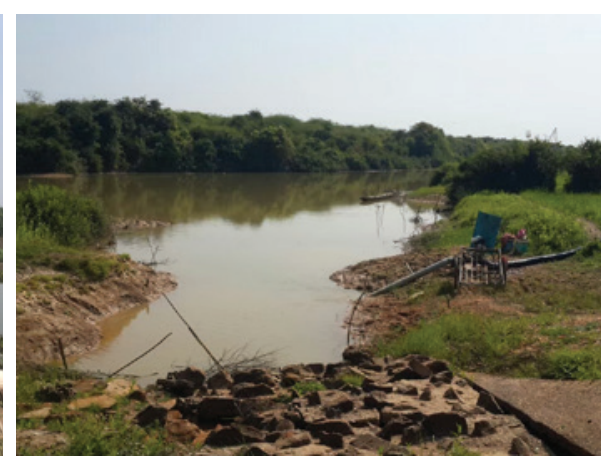

TSK, Floodplain at Nakhon Phanom province

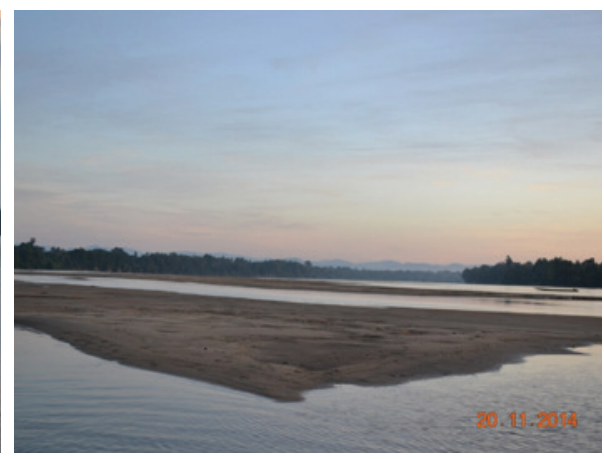

CSS, Sesan at Ratanakiri province

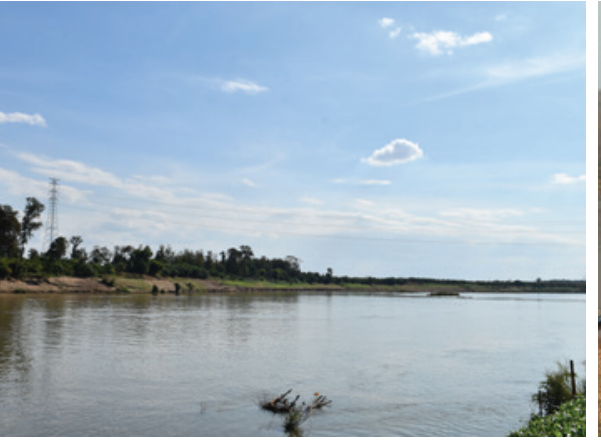

LAP, Tributary at Attapeu province

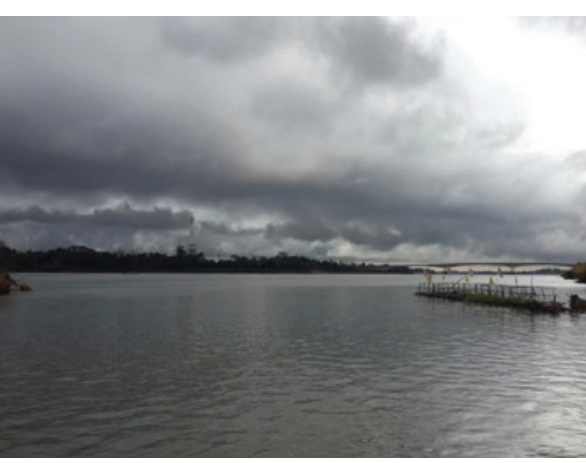

TUT, Mainstream at Nakhon Phanom province

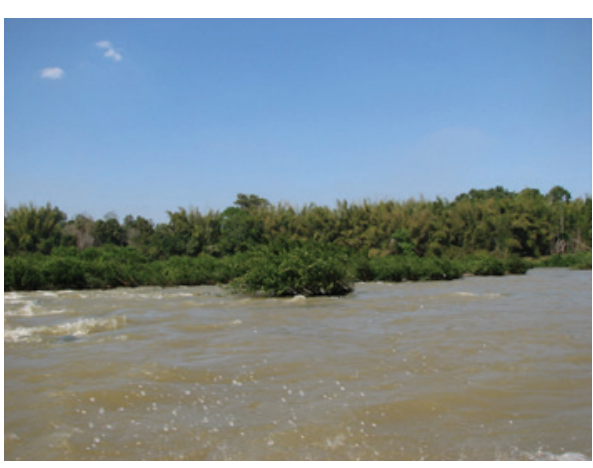

CSP, Srepok at Ratanakiri province

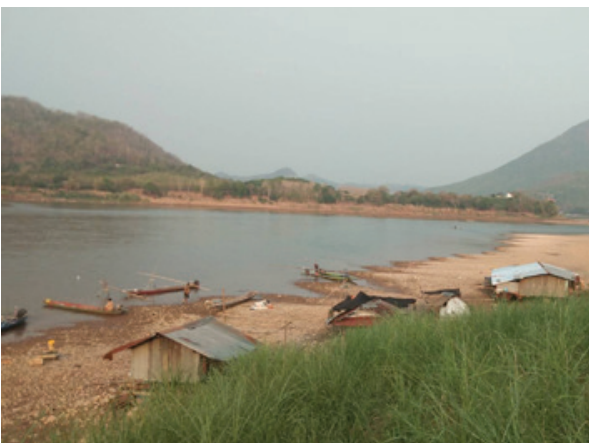

TCK, Mainstream at Loei province

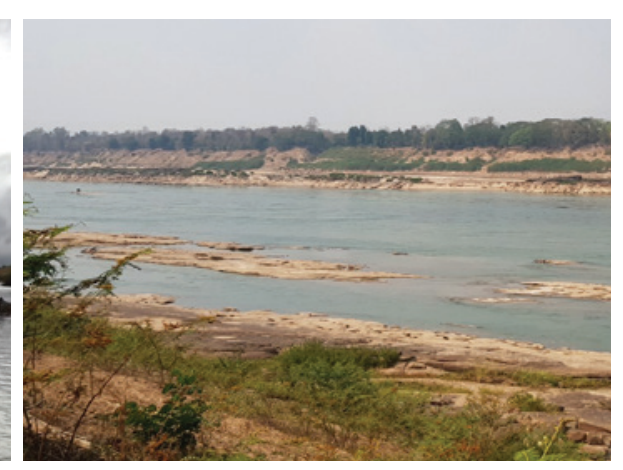

TKR, Mainstream at Ubon Ratchathani province

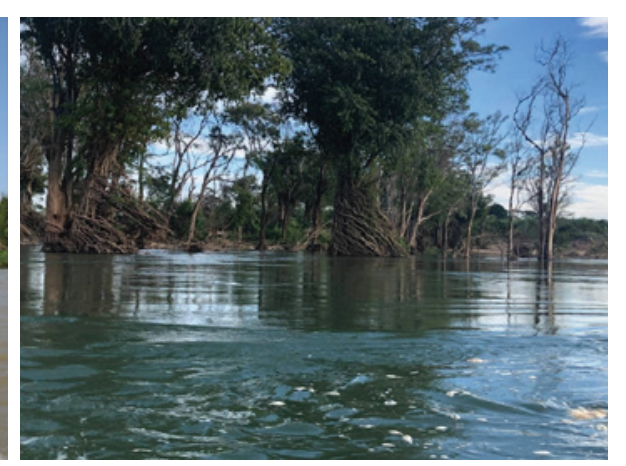

CST, Mainstream at Stung Treng province 


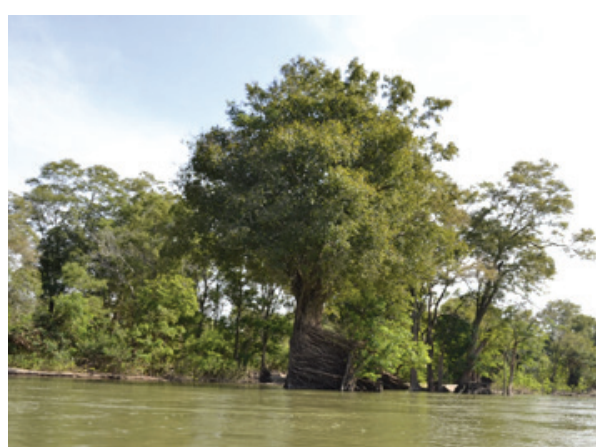

CKT, Mainstream at Kratei province

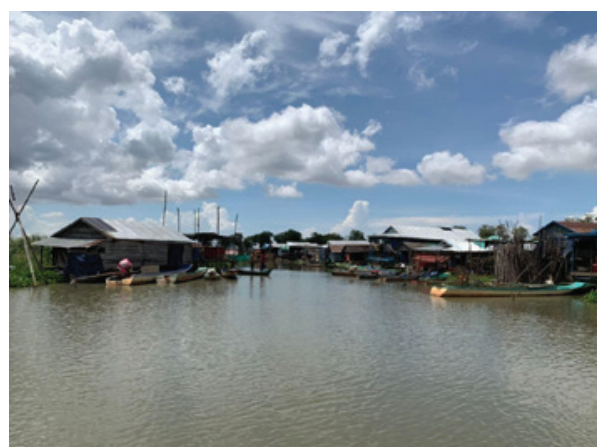

CPS, Floodplain at Pursat province

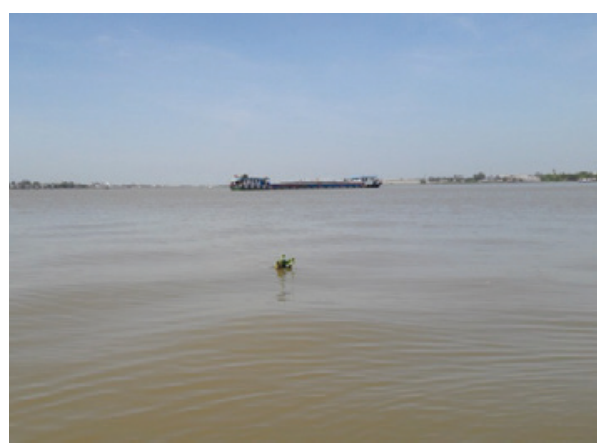

VCM, Mainstream at An Giang province

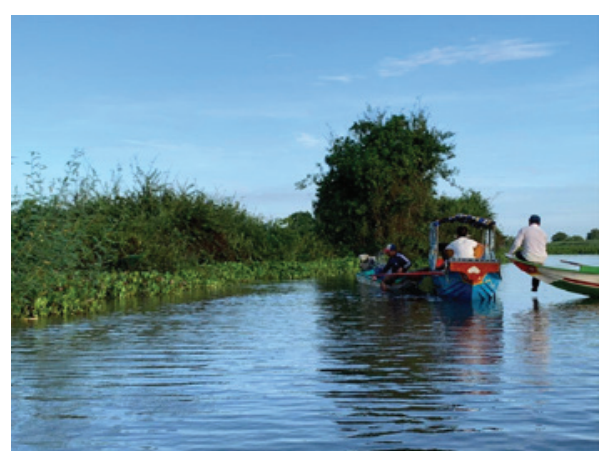

CBT, Floodplain at Battambang province

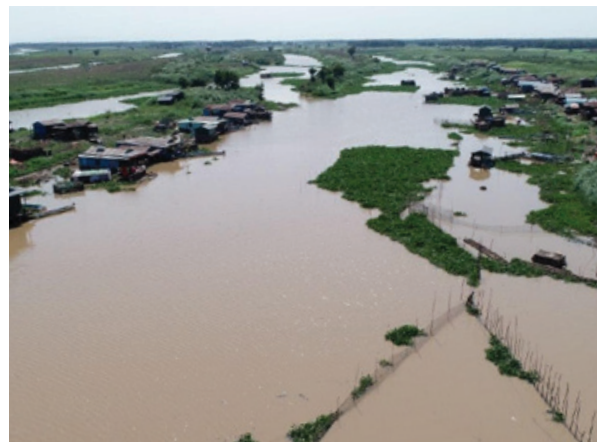

CKC, Floodplain at Kompong Chhang province

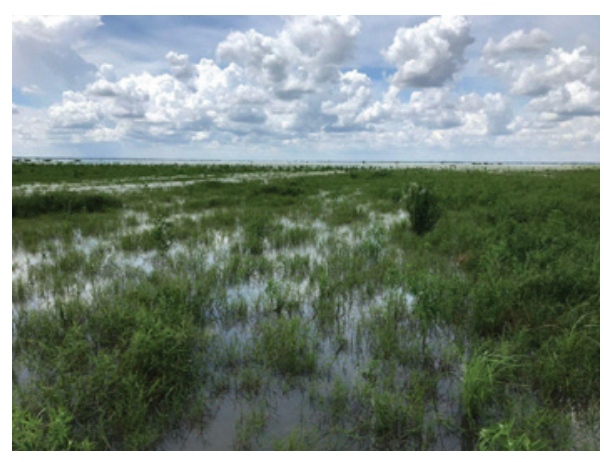

CSR, Floodplain at Siem Reap province

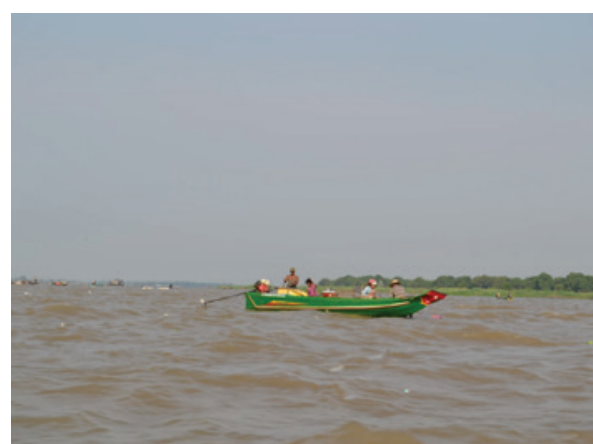

CKD, Tributary at Kandal province

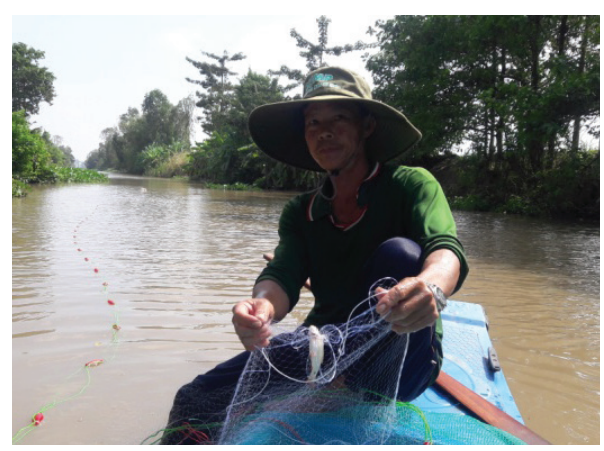

VTS, Floodplain at An Giang province

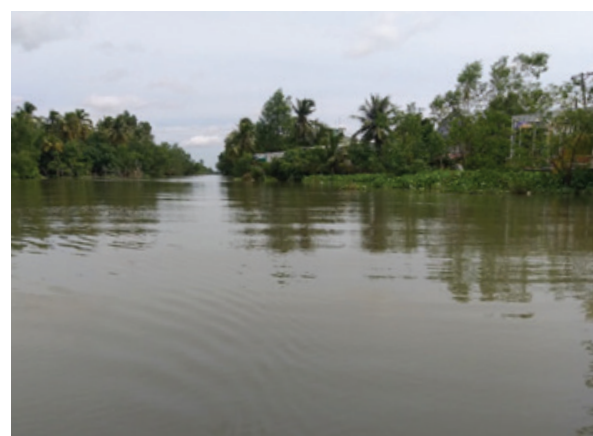

VCT, Floodplain at Can Tho province

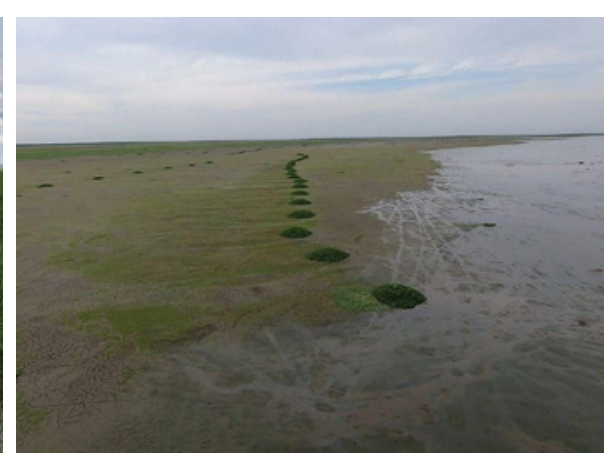

CPT, Floodplain at Kompong Thom province

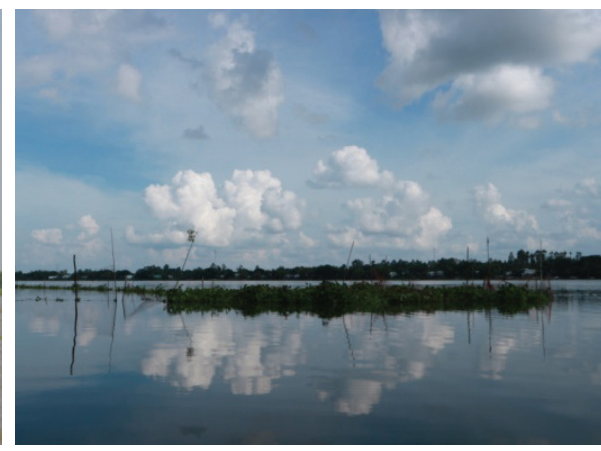

VAP, Canal at An Giang province

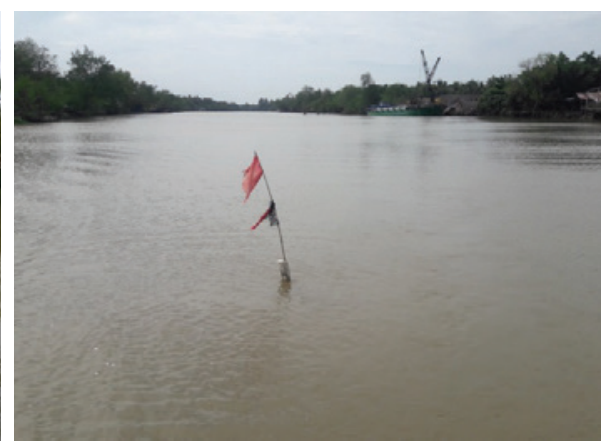

VTV, Estuarine at Tra Vinh province 


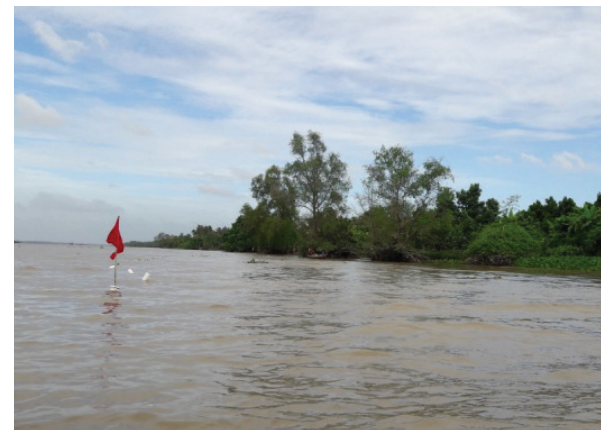

VVL, Estuarine at Vinh Long province

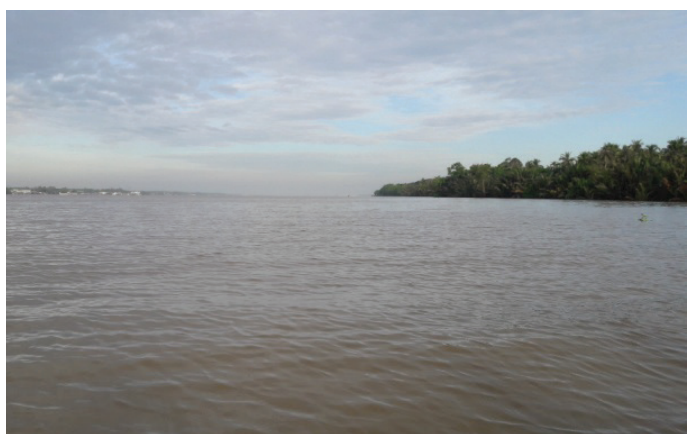

VLT, Estuarine at Tra Vinh province

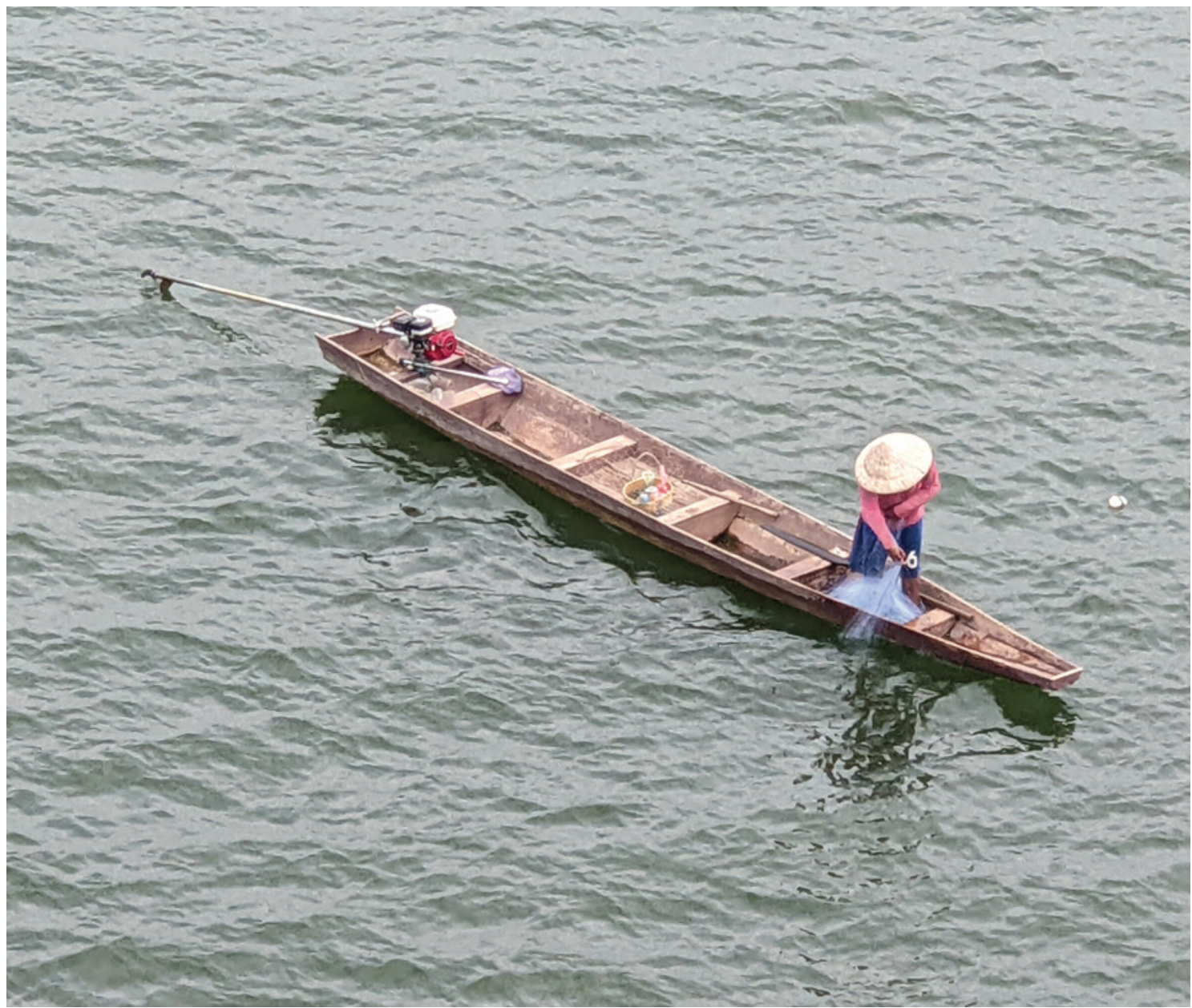




\section{Annex 2: Catch per Unit Effort for All Stations Clustered by BioRA Zon}
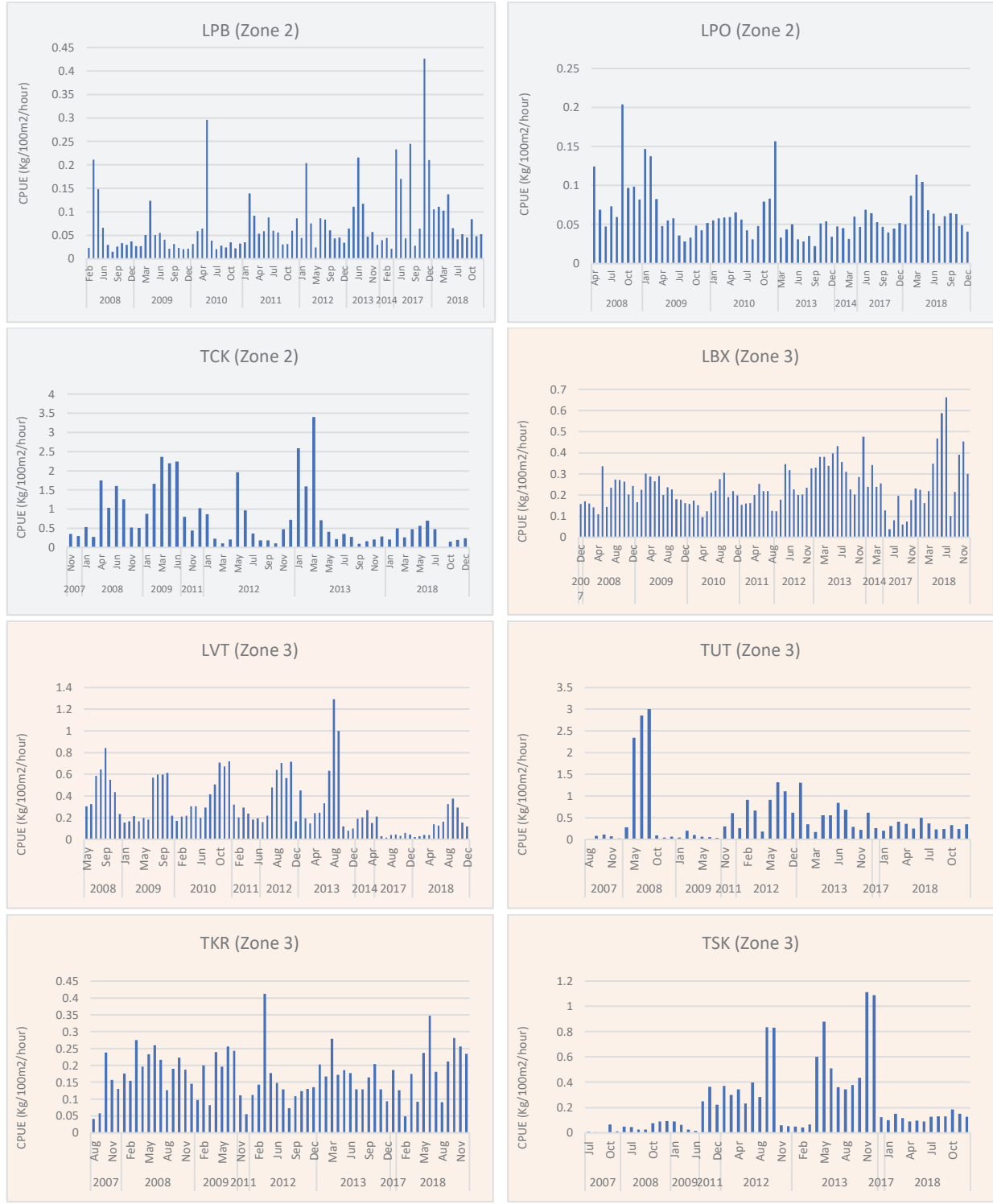

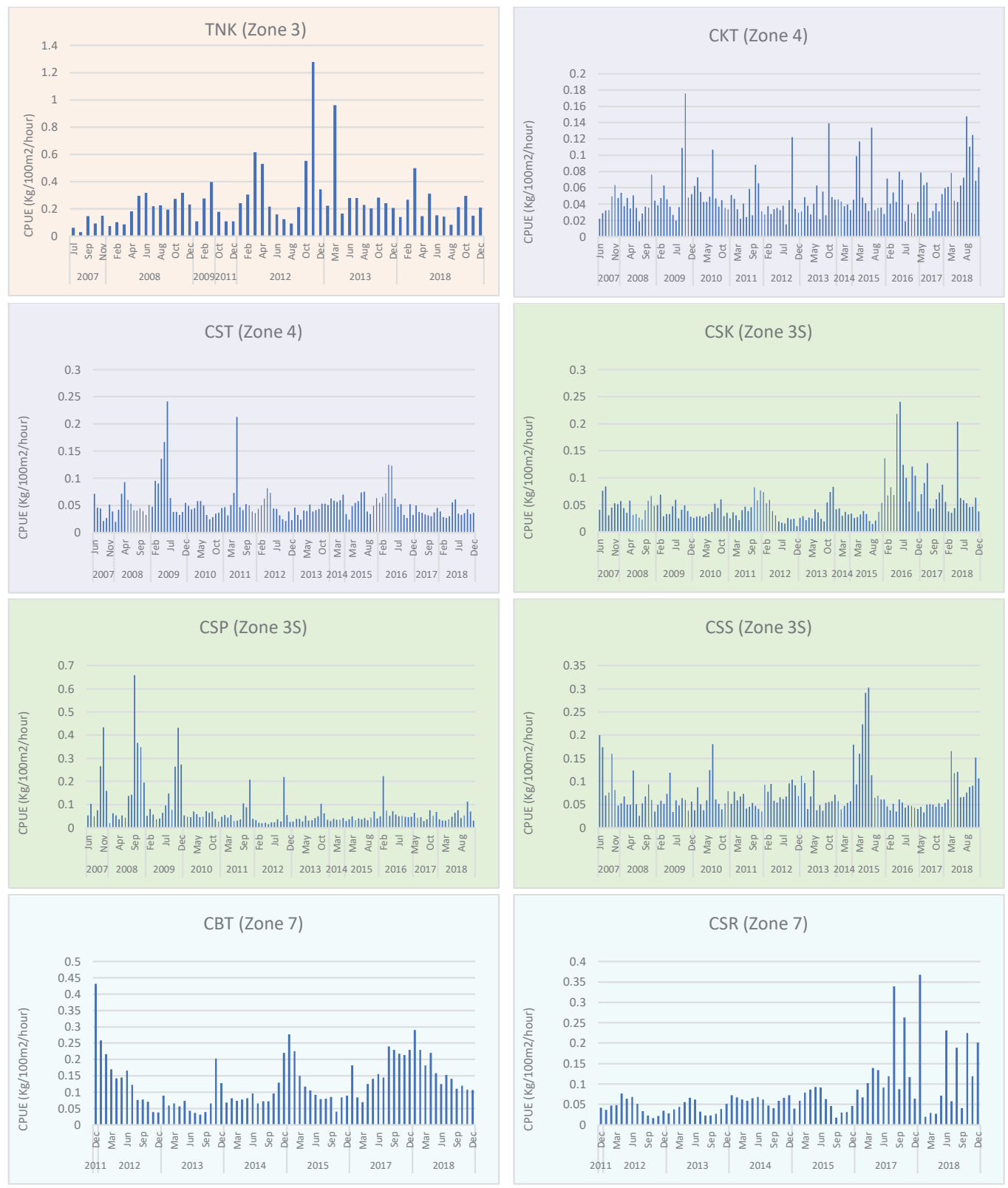

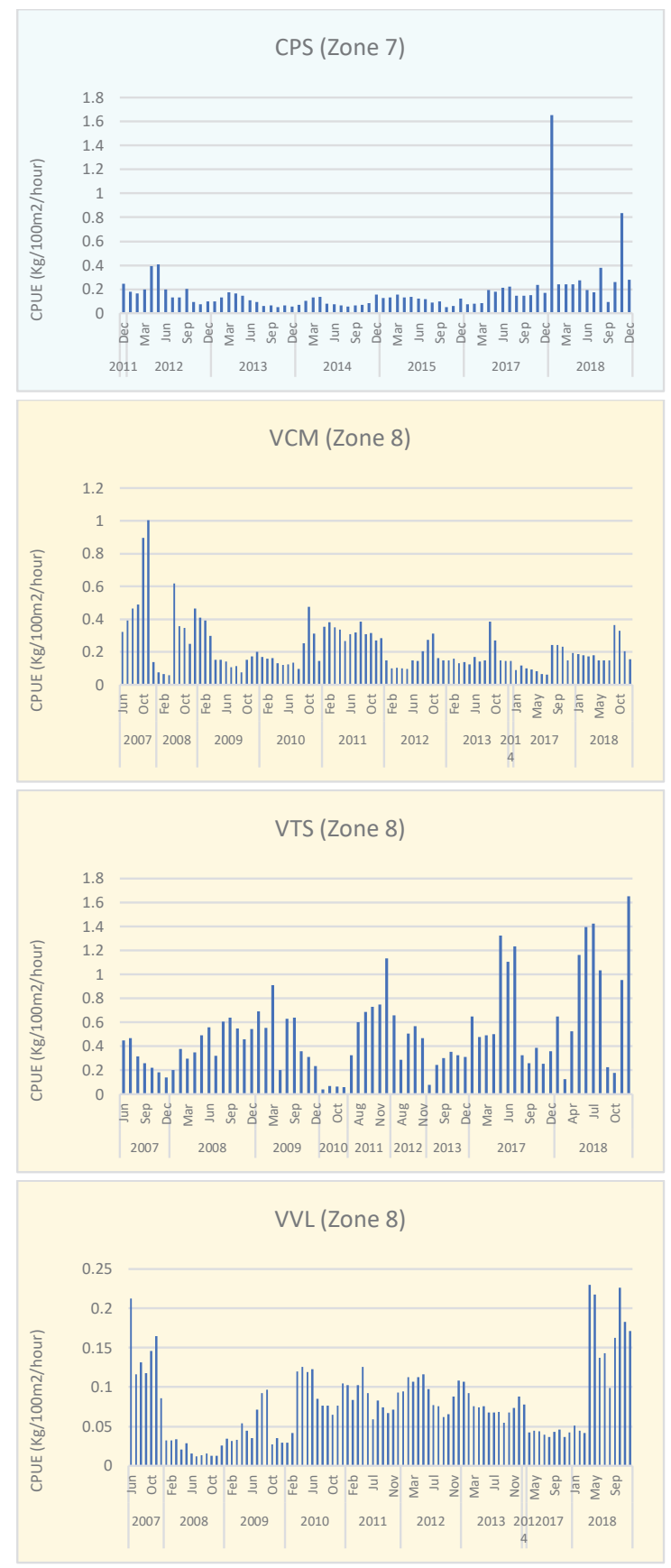

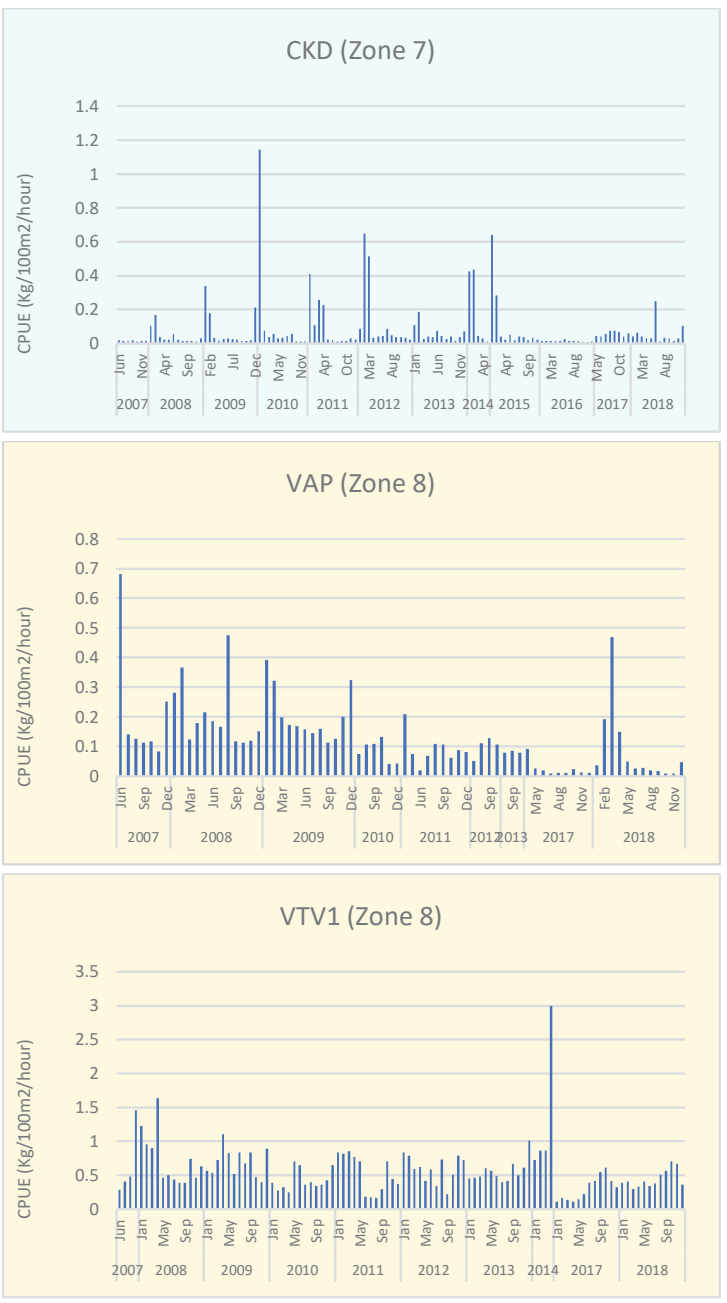


Annex 3: Distribution of Maximum Length for Important Species in 2018
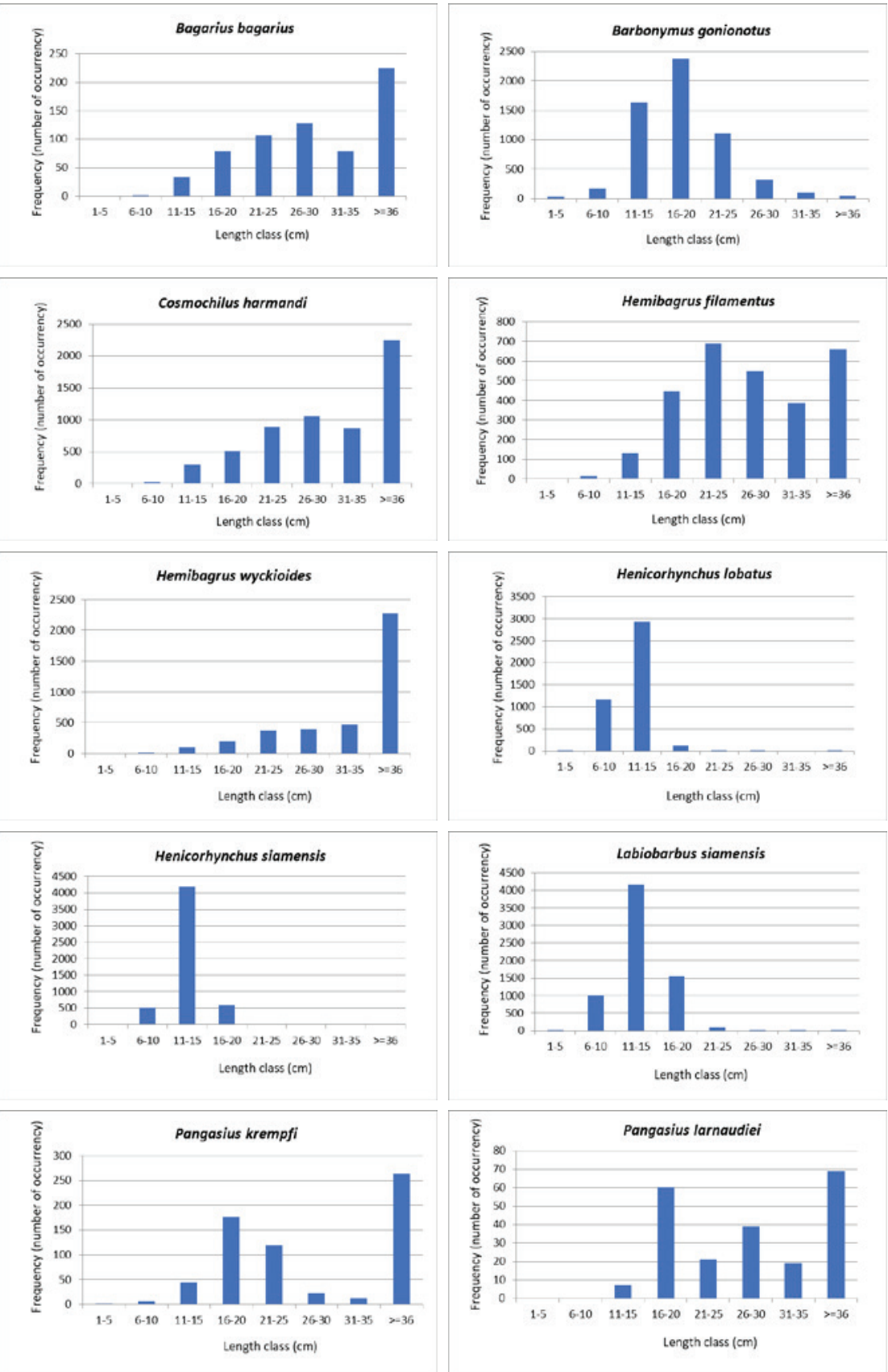
STATUS AND TRENDS OF FISH ABUNDANCE AND DIVERSITY IN THE

LOWER MEKONG BASIN DURING 2007-2018
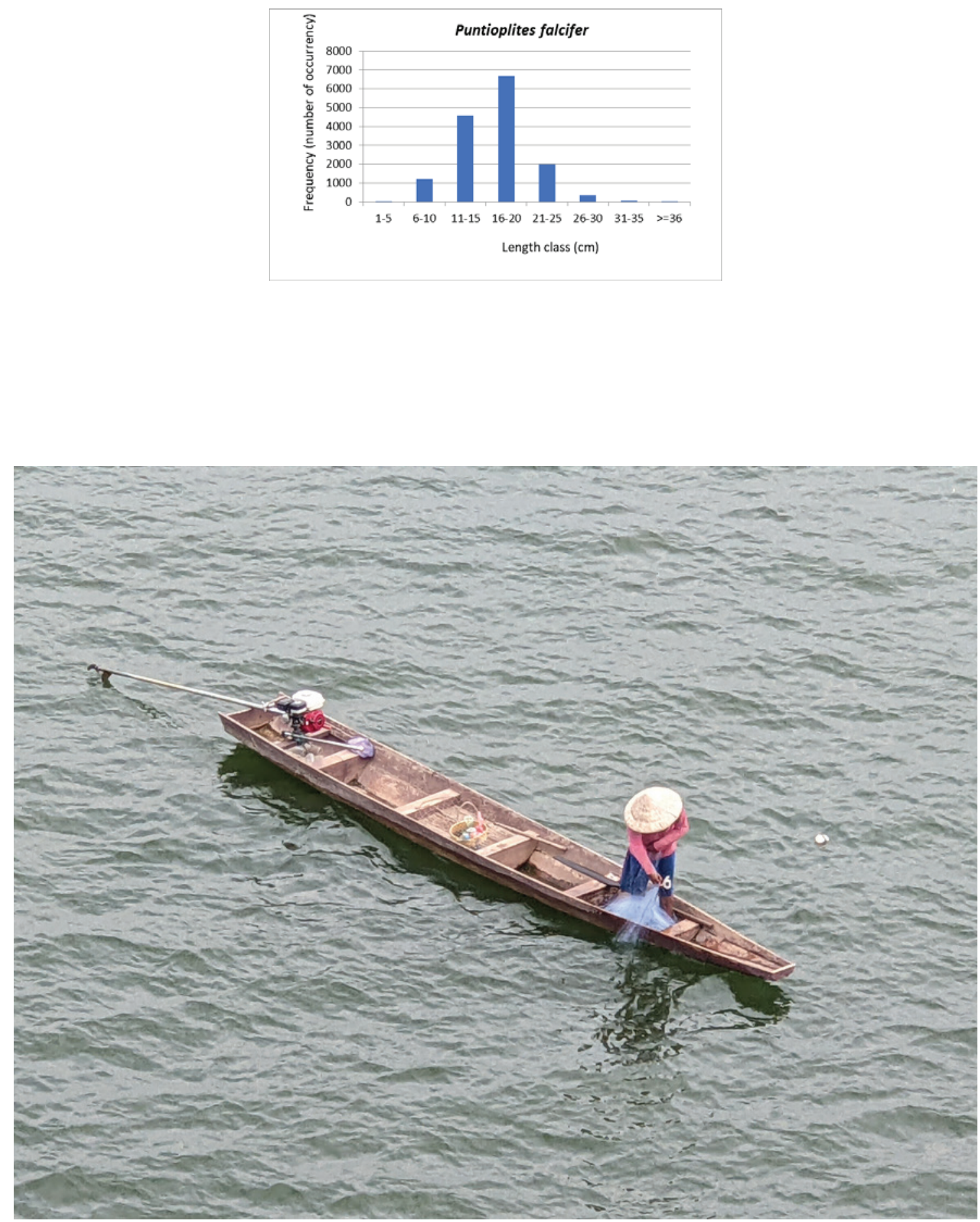
Annex 4: LMB Fish Species List with Short Names, Invasion Status, Guild and Conservation Status

\begin{tabular}{|c|c|c|c|c|c|c|}
\hline Order & Family & Scientific Name & Short Name & Invasive Status & Guild & IUCN Category \\
\hline Cypriniformes & Cyprinidae & Aaptosyax grypus & Aapypu & Indigenous & G3 & CR \\
\hline Cypriniformes & Cyprinidae & Abbottina rivularis & Abbvul & Exotic & G11 & NA \\
\hline Cypriniformes & Cobitidae & Acantopsis sp. & Aca. & Indigenous & G3 & NA \\
\hline Cypriniformes & Cobitidae & Acanthopsis sp.1 & Aca.1 & Indigenous & G3 & NA \\
\hline Cypriniformes & Cobitidae & Acanthopsis sp. 2 & Aca. 2 & Indigenous & G3 & NA \\
\hline Cypriniformes & Cobitidae & Acanthopsis sp. 5 & Aca. 5 & Indigenous & G3 & NA \\
\hline Cypriniformes & Cobitidae & Acanthopsoides gracilentus & Acaaci & Indigenous & G3 & LC \\
\hline Cypriniformes & Cobitidae & Acantopsis sp "cheek spot" & Acaeek & Indigenous & G3 & NA \\
\hline Siluriformes & Siluridae & $\begin{array}{l}\text { Acanthocobitis sp. cf. } \\
\text { bilotorio }\end{array}$ & Acalot & Indigenous & G3 & NA \\
\hline Cypriniformes & Cobitidae & Acanthopsoides delphax & Acalph & Indigenous & G3 & LC \\
\hline Cypriniformes & Cobitidae & $\begin{array}{l}\text { Acantopsis spp. Thai Catch/ } \\
\text { Mkt }\end{array}$ & Acanspp & Indigenous & G3 & NA \\
\hline Cypriniformes & Cobitidae & $\begin{array}{l}\text { Acanthopsoides spp. Thai } \\
\text { Catch }\end{array}$ & Acanth & Indigenous & G3 & NA \\
\hline Cypriniformes & Cobitidae & Acanthopsoides hapalias & Acapal & Indigenous & G3 & LC \\
\hline Pleuronectiformes & Soleidae & Achiroides melanorhynchus & Achlan & Indigenous & G7 & NA \\
\hline Cypriniformes & Cyprinidae & Acheilognathus barbatulus & Achrba & Indigenous & G4 & LC \\
\hline Pleuronectiformes & Soleidae & Achiroides leucorhynchos & Achuco & Indigenous & G7 & NA \\
\hline Myliobatiformes & Myliobatidae & Aetomylaeus nichofii & Aetcho & Indigenous & G10 & NA \\
\hline Siluriformes & Akysidae & Akysis brachybarbatus & Akyach & Indigenous & G1 & NA \\
\hline Siluriformes & Akysidae & Akysis inermis & Akyerm & Indigenous & G3 & NA \\
\hline Siluriformes & Akysidae & Akysis similis & Akymil & Indigenous & G3 & NA \\
\hline Siluriformes & Akysidae & akysis hendricksoni & akyndr & NA & $?$ & NA \\
\hline
\end{tabular}




\begin{tabular}{|c|c|c|c|c|c|c|}
\hline Order & Family & Scientific Name & Short Name & Invasive Status & Guild & IUCN Category \\
\hline Siluriformes & Akysidae & Akysis varius & Akyriu & Indigenous & G1 & DD \\
\hline Cypriniformes & Cyprinidae & Albulichthys albuloides & Albbul & Indigenous & G3 & LC \\
\hline Batrachoidiformes & Batrachoididae & Allenbatrachus grunniens & Allunn & Indigenous & G7 & NA \\
\hline Cypriniformes & Cyprinidae & $\begin{array}{l}\text { Amblyrhynchichthys } \\
\text { micracanthus }\end{array}$ & Ambcra & Indigenous & G3 & LC \\
\hline Siluriformes & Amblycipitidae & Amblyceps mucronatum & Ambcro & Indigenous & G1 & NA \\
\hline Perciformes & Gobiidae & $\begin{array}{l}\text { Amblyotrypauchen } \\
\text { arctocephalus }\end{array}$ & Ambcto & Indigenous & G7 & NA \\
\hline Perciformes & Chandidae & Ambassis gymnocephalus & Ambmno & Indigenous & G7 & NA \\
\hline Siluriformes & Amblycipitidae & Amblyceps foratum & Ambrat & Indigenous & G1 & LC \\
\hline Perciformes & Chandidae & Ambassis buruensis & Ambrue & Indigenous & G7 & NA \\
\hline Perciformes & Ambassidae & Ambassidae spA Thai Catch & AmbspA & Indigenous & G7 & NA \\
\hline Cypriniformes & Cyprinidae & $\begin{array}{l}\text { Amblyrhynchichthys } \\
\text { truncatus }\end{array}$ & Ambunc & Indigenous & G3 & NA \\
\hline Perciformes & Anabantidae & Anabas testudineus & Anastu & Indigenous & G6 & DD \\
\hline Anguilliformes & Anguillidae & Anguilla bicolor & Angcol & Indigenous & G9 & NA \\
\hline Anguilliformes & Anguillidae & Anguilla marmorata & Angrmo & Indigenous & G9 & NA \\
\hline Clupeiformes & Clupeidae & Anodontostoma chacunda & Anoacu & Indigenous & G10 & NA \\
\hline Cyprinodontiformes & Aplocheilidae & Aplocheilus panchax & Aplnch & Indigenous & G7 & LC \\
\hline Perciformes & Gobiidae & Apocryptodon madurensis & Apodur & Indigenous & G7 & NA \\
\hline Siluriformes & Ariidae & Arius macracanthus & Aricra & Indigenous & $?$ & NA \\
\hline Siluriformes & Ariidae & Arius macronotacanthus & Aricro & Indigenous & G7 & NA \\
\hline Siluriformes & Ariidae & Arius maculatus & Aricul & Indigenous & G7 & NA \\
\hline Siluriformes & Ariidae & Arius caelatus & Ariela & Indigenous & G7 & NA \\
\hline Siluriformes & Ariidae & Arius sagor & Arigor & Indigenous & G7 & NA \\
\hline Siluriformes & Ariidae & Arius argyropleuron & Arigyr & Indigenous & G7 & NA \\
\hline
\end{tabular}




\begin{tabular}{|c|c|c|c|c|c|c|}
\hline Order & Family & Scientific Name & Short Name & Invasive Status & Guild & IUCN Category \\
\hline Siluriformes & Ariidae & Arius sciurus & Ariiur & Indigenous & G7 & NA \\
\hline Siluriformes & Ariidae & Arius malacanthus & Arilac & Indigenous & $\mathrm{G} 2$ & NA \\
\hline Siluriformes & Ariidae & Arius venosus & Arinos & Indigenous & G7 & NA \\
\hline Siluriformes & Ariidae & Arius crossocheilos & Arioss & Indigenous & G7 & NA \\
\hline Siluriformes & Ariidae & Arius leptonotacanthus & Aripto & Indigenous & G7 & NA \\
\hline Siluriformes & Ariidae & Arius truncatus & Ariunc & Indigenous & G7 & NA \\
\hline Perciformes & Sciaenidae & Aspericorvina jubata & Aspbat & Indigenous & G10 & NA \\
\hline Perciformes & Carangidae & Atule mat & Atut & Indigenous & G10 & NA \\
\hline Tetraodontiformes & Tetraodontidae & Auriglobus modestus & Aurdes & Indigenous & G1 & LC \\
\hline Perciformes & Nandidae & Badis ruber & Badber & Indigenous & G4 & LC \\
\hline Siluriformes & Sisoridae & Bagarius suchus & Bagchu & Indigenous & G1 & NT \\
\hline Siluriformes & Bagridae & Bagrichthys macracanthus & Bagcra & Indigenous & G3 & NA \\
\hline Siluriformes & Sisoridae & Bagarius bagarius & Baggar & Indigenous & G1 & NT \\
\hline Siluriformes & Sisoridae & Bagarius yarrelli & Bagrre & Indigenous & G1 & NT \\
\hline Siluriformes & Bagridae & Bagrichthys obscurus & Bagscu & Indigenous & G3 & LC \\
\hline Perciformes & Sciaenidae & Bahaba polykladiskos & Bahlyk & Indigenous & G10 & NA \\
\hline Cypriniformes & Cyprinidae & $\begin{array}{l}\text { Balantiocheilos } \\
\text { melanopterus }\end{array}$ & Ballan & Indigenous & G3 & NA \\
\hline Cypriniformes & Cyprinidae & Bangana elegans & Banega & Indigenous & G3 & NT \\
\hline Cypriniformes & Cyprinidae & Bangana behri & Banhri & Indigenous & G3 & VU \\
\hline Cypriniformes & Cyprinidae & Bangana lippus & Banppu & Indigenous & G3 & NA \\
\hline Cypriniformes & Cyprinidae & Bangana sp. & Bansp & Indigenous & G3 & NA \\
\hline Cypriniformes & Cyprinidae & Barbonymus schwanenfeldii & Barhwa & Indigenous & G4 & LC \\
\hline Cypriniformes & Cyprinidae & Barbonymus gonionotus & Barnio & Indigenous & G5 & LC \\
\hline Cypriniformes & Cyprinidae & Barbichthys nitidus & Bartid & Indigenous & G3 & NA \\
\hline
\end{tabular}




\begin{tabular}{|c|c|c|c|c|c|c|}
\hline Order & Family & Scientific Name & Short Name & Invasive Status & Guild & IUCN Category \\
\hline Cypriniformes & Cyprinidae & Barbonymus altus & Bartus & Indigenous & G4 & LC \\
\hline Batrachoidiformes & Batrachoididae & Batrachomoeus trispinosus & Batisp & Indigenous & G7 & NA \\
\hline Siluriformes & Ariidae & Batrachocephalus mino & Batno & Indigenous & G7 & NA \\
\hline Batrachoidiformes & Batrachoididae & Batrichthys grunniens & Batunn & Indigenous & G7 & NA \\
\hline Siluriformes & Siluridae & Belodontichthys dinema & Belnem & Exotic & G11 & NA \\
\hline Siluriformes & Siluridae & Belodontichthys truncatus & Belunc & Indigenous & G3 & LC \\
\hline Perciformes & Osphronemidae & Betta smaragdina & Betara & Indigenous & G6 & DD \\
\hline Perciformes & Osphronemidae & Betta prima & Betima & Indigenous & G6 & LC \\
\hline Perciformes & Sciaenidae & Boesemania microlepis & Boecro & Indigenous & G4 & NT \\
\hline Cypriniformes & Cyprinidae & Boraras micros & Borcro & Indigenous & G6 & LC \\
\hline Cypriniformes & Cyprinidae & Boraras urophthalmoides & Boroph & Indigenous & G6 & NT \\
\hline Perciformes & Eleotridae & Bostrychus sinensis & Bosnen & Indigenous & G10 & LC \\
\hline Cypriniformes & Cobitidae & Botia beauforti & Botauf & Indigenous & G3 & NA \\
\hline Siluriformes & Siluridae & Botia sp. cf. beauforti & Botaufo & Indigenous & G3 & NA \\
\hline Cypriniformes & Cobitidae & Botia lecontei & Botcon & Indigenous & G3 & NA \\
\hline Siluriformes & Siluridae & Botia sp. cf. lecontei & Botcont & Indigenous & G3 & NA \\
\hline Cypriniformes & Cobitidae & Botia modesta & Botdes & Indigenous & G3 & NA \\
\hline Cypriniformes & Cobitidae & Botia sidthimunki & Botdth & Indigenous & G3 & NA \\
\hline Cypriniformes & Cobitidae & Botia eos & Boteos & Indigenous & G3 & NA \\
\hline Cypriniformes & Cobitidae & Botia nigrolineata & Botgro & Indigenous & G3 & VU \\
\hline Cypriniformes & Cobitidae & Botia splendida & Botlen & Indigenous & G3 & NA \\
\hline Cypriniformes & Cobitidae & Botia helodes & Botlod & Indigenous & G3 & NA \\
\hline Cypriniformes & Cobitidae & Botia longidorsalis & Botngi & Indigenous & G3 & NA \\
\hline Cypriniformes & Cobitidae & Botia morleti & Botrle & Indigenous & G3 & NA \\
\hline
\end{tabular}




\begin{tabular}{|c|c|c|c|c|c|c|}
\hline Order & Family & Scientific Name & Short Name & Invasive Status & Guild & IUCN Category \\
\hline Cypriniformes & Cobitidae & Botia caudipunctata & Botudi & Indigenous & G3 & NA \\
\hline Pleuronectiformes & Soleidae & Brachirus orientalis & Braien & Indigenous & G10 & NA \\
\hline Pleuronectiformes & Soleidae & Brachirus panoides & Branoi & Indigenous & G7 & LC \\
\hline Pleuronectiformes & Soleidae & Brachirus harmandi & Brarma & Indigenous & G5 & LC \\
\hline Perciformes & Eleotridae & Butis amboinensis & Butboi & Indigenous & G7 & NA \\
\hline Perciformes & Eleotridae & Butis koilomatodon & Butilo & Indigenous & G7 & NA \\
\hline Perciformes & Eleotridae & Butis butis & Buttis & Indigenous & G7 & LC \\
\hline Perciformes & Carangidae & Carangoides armatus & Carmat & Indigenous & G10 & NA \\
\hline Carcharhiniformes & Carcharhinidae & Carcharhinus limbatus & Carmba & Indigenous & G10 & NA \\
\hline Tetraodontiformes & Tetraodontidae & Carinotetraodon lorteti & Carrte & Indigenous & G7 & LC \\
\hline Carcharhiniformes & Carcharhinidae & Carcharhinus dussumieri & Carssu & Indigenous & G10 & NA \\
\hline Carcharhiniformes & Carcharhinidae & Carcharhinus leucas & Caruca & Indigenous & G10 & NA \\
\hline Cypriniformes & Cyprinidae & Catlocarpio siamensis & Catame & Indigenous & G10 & CR \\
\hline Siluriformes & Siluridae & Ceratoglanis pachynema & Cerchy & Indigenous & G3 & NA \\
\hline Perciformes & Channidae & Channa grandinosa & Chaand & Indigenous & G6 & NA \\
\hline Perciformes & Channidae & Channa gachua & Chachu & Indigenous & G1 & LC \\
\hline Perciformes & Channidae & Channa lucius & Chaciu & Indigenous & G6 & LC \\
\hline Perciformes & Channidae & Channa micropeltes & Chacro & Indigenous & G6 & LC \\
\hline Perciformes & Channidae & Channa melasoma & Chalas & Indigenous & G6 & NA \\
\hline Perciformes & Channidae & Channa limbata & Chamba & Indigenous & G1 & NA \\
\hline Perciformes & Channidae & Channa striata & Charia & Indigenous & G6 & LC \\
\hline Perciformes & Channidae & Channa marulioides & Charul & Indigenous & G6 & NA \\
\hline Synbranchiformes & Chaudhuriidae & Chaudhuria fusipinnis & Chasip & Indigenous & G6 & $\mathrm{DD}$ \\
\hline Mugiliformes & Mugilidae & Chelon subviridis & Chebvi & Indigenous & G10 & NA \\
\hline
\end{tabular}




\begin{tabular}{|c|c|c|c|c|c|c|}
\hline Order & Family & Scientific Name & Short Name & Invasive Status & Guild & IUCN Category \\
\hline Cypriniformes & Cyprinidae & Chela laubuca & Cheubu & Indigenous & G4 & NA \\
\hline Osteoglossiformes & Notopteridae & Chitala blanci & Chianc & Indigenous & G1 & NT \\
\hline Osteoglossiformes & Notopteridae & Chitala ornata & Chinat & Indigenous & G5 & LC \\
\hline Osteoglossiformes & Notopteridae & Chitala lopis & Chipis & Indigenous & G3 & LC \\
\hline Scorpaeniformes & Scorpaenidae & Choriodactylus multibarbus & Cholti & Indigenous & G10 & NA \\
\hline Perciformes & Sciaenidae & Chrysochir aureus & Chrreu & Indigenous & G10 & NA \\
\hline Cypriniformes & Cyprinidae & Cirrhinus microlepis & Circro & Indigenous & G3 & VU \\
\hline Cypriniformes & Cyprinidae & Cirrhinus spilopleura & Cirilo & Indigenous & G3 & NA \\
\hline Cypriniformes & Cyprinidae & Cirrhinus molitorella & Cirlit & Indigenous & G3 & NT \\
\hline Cypriniformes & Cyprinidae & Cirrhinus jullieni & Cirlli & Indigenous & G3 & DD \\
\hline Cypriniformes & Cyprinidae & Cirrhinus prosemion & Cirose & Indigenous & G3 & NA \\
\hline Cypriniformes & Cyprinidae & Cirrhinus cirrhosus & Cirrrh & Exotic & G11 & NA \\
\hline Siluriformes & Clariidae & Clarias macrocephalus & Clacro & Indigenous & G6 & NT \\
\hline Siluriformes & Clariidae & Clarias nieuhofi & Claeuh & Indigenous & G6 & NA \\
\hline Siluriformes & Clariidae & Clarias meladerma & Clalad & Indigenous & G6 & NA \\
\hline Siluriformes & Clariidae & Clarias gariepinus & Clarie & Exotic & G11 & NA \\
\hline Siluriformes & Clariidae & Clarias fuscus & Clascu & Indigenous & G6 & LC \\
\hline Siluriformes & Clariidae & Clarias sp. & Clasp & Exotic & G6 & NA \\
\hline Siluriformes & Clariidae & Clarias cataractus & Clatar & Indigenous & G6 & NA \\
\hline Siluriformes & Clariidae & Clarias batrachus & Clatra & Indigenous & G6 & LC \\
\hline Siluriformes & Schilbeidae & Clupisoma sinensis & Clunen & Indigenous & G3 & LC \\
\hline Siluriformes & Schilbeidae & Clupisoma longianalis & Clungi & Indigenous & G3 & NA \\
\hline Clupeiformes & Clupeidae & Clupeoides borneensis & Clurne & Indigenous & G3 & LC \\
\hline Clupeiformes & Clupeidae & Clupeichthys aesarnensis & Clusar & Indigenous & G3 & LC \\
\hline
\end{tabular}




\begin{tabular}{|c|c|c|c|c|c|c|}
\hline Order & Family & Scientific Name & Short Name & Invasive Status & Guild & IUCN Category \\
\hline Clupeiformes & Engraulidae & Coilia rebentischii & Coiben & Indigenous & G10 & NA \\
\hline Clupeiformes & Engraulidae & Coilia macrognathos & Coicro & Indigenous & G10 & NA \\
\hline Clupeiformes & Engraulidae & Coilia lindmani & Coindm & Indigenous & G7 & LC \\
\hline Characiformes & Characidae & Colossoma macropomum & Colcro & Exotic & G11 & NA \\
\hline Anguilliformes & Muraenesocidae & Congresox talabon & Conlab & Indigenous & G10 & NA \\
\hline Anguilliformes & Muraenesocidae & Congresox talabonoides & Conlabo & Indigenous & G10 & NA \\
\hline Clupeiformes & Clupeidae & Corica soborna & Corbor & Indigenous & G3 & NA \\
\hline Clupeiformes & Clupeidae & Corica laciniata & Corcin & Indigenous & G3 & NA \\
\hline Cypriniformes & Cyprinidae & Cosmochilus cardinalis & Cosrdi & Indigenous & G2 & NA \\
\hline Cypriniformes & Cyprinidae & Cosmochilus harmandi & Cosrma & Indigenous & $\mathrm{G} 2$ & LC \\
\hline Cypriniformes & Cyprinidae & Crossocheilus cobitis & Crobit & Indigenous & G5 & NA \\
\hline Cypriniformes & Cyprinidae & Crossocheilus atrilimes & Croril & Indigenous & G5 & LC \\
\hline Cypriniformes & Cyprinidae & Crossocheilus reticulatus & Crotic & Indigenous & G5 & LC \\
\hline Cypriniformes & Cyprinidae & Ctenopharyngodon idella & Cteell & Exotic & G4 & NA \\
\hline Cypriniformes & Cyprinidae & Cyclocheilichthys lagleri & Cycgle & Indigenous & G4 & LC \\
\hline Cypriniformes & Cyprinidae & $\begin{array}{l}\text { Cyclocheilichthys } \\
\text { mekongensis }\end{array}$ & Cyckon & Indigenous & G4 & NA \\
\hline Cypriniformes & Cyprinidae & Cyclocheilichthys armatus & Cycmat & Indigenous & G4 & LC \\
\hline Cypriniformes & Cyprinidae & Cyclocheilichthys apogon & Cycogo & Indigenous & G4 & LC \\
\hline Cypriniformes & Cyprinidae & Cyclocheilichthys enoplos & Cycopl & Indigenous & G2 & LC \\
\hline Cypriniformes & Cyprinidae & Cyclocheilichthys repasson & Cycpas & Indigenous & G4 & LC \\
\hline Cypriniformes & Cyprinidae & Cyclocheilichthys tapiensis & Cycpie & Indigenous & G4 & NA \\
\hline Cypriniformes & Cyprinidae & Cyclocheilichthys furcatus & Cycrca & Indigenous & G2 & LC \\
\hline Cypriniformes & Cyprinidae & $\begin{array}{l}\text { Cyclochelichthys spA Thai } \\
\text { Catch }\end{array}$ & CycspA & Indigenous & G4 & NA \\
\hline
\end{tabular}




\begin{tabular}{|c|c|c|c|c|c|c|}
\hline Order & Family & Scientific Name & Short Name & Invasive Status & Guild & IUCN Category \\
\hline Cypriniformes & Cyprinidae & $\begin{array}{l}\text { Cyclocheilichthys } \\
\text { heteronema }\end{array}$ & Cycter & Indigenous & G4 & LC \\
\hline Pleuronectiformes & Cynoglossidae & Cynoglossus microlepis & Cyncro & Indigenous & G10 & LC \\
\hline Pleuronectiformes & Cynoglossidae & Cynoglossus feldmanni & Cynldm & Indigenous & G10 & LC \\
\hline Pleuronectiformes & Cynoglossidae & Cynoglossus bilineatus & Cynlin & Indigenous & G10 & NA \\
\hline Pleuronectiformes & Cynoglossidae & Cynoglossus puncticeps & Cynnct & Indigenous & G10 & NA \\
\hline Pleuronectiformes & Cynoglossidae & Cynoglossus lingua & Cynngu & Indigenous & G10 & NA \\
\hline Pleuronectiformes & Cynoglossidae & Cynoglossus cynoglossus & Cynnog & Indigenous & G10 & NA \\
\hline Beloniformes & Exocoetidae & Cypselurus poecilopterus & Cypeci & Indigenous & G10 & NA \\
\hline Cypriniformes & Cyprinidae & Cyprinus barbatus & Cyprba & Indigenous & G4 & NA \\
\hline Cypriniformes & Cyprinidae & Cyprinus carpio & Cyprpi & Exotic & G11 & NA \\
\hline Cypriniformes & Cyprinidae & Danio tweediei & Daneed & Indigenous & G6 & NA \\
\hline Cypriniformes & Cyprinidae & Danio roseus & Danseu & Indigenous & G6 & LC \\
\hline Myliobatiformes & Dasyatidae & Dasyatis zugei & Dasgei & Indigenous & G10 & NA \\
\hline Myliobatiformes & Dasyatidae & Dasyatis laosensis & Dasose & Indigenous & G3 & EN \\
\hline Perciformes & Datnioididae & Datnioides polota & Datadr & Indigenous & G7 & LC \\
\hline Perciformes & Datnioididae & Datnioides undecimradiatus & Datdec & Indigenous & G3 & VU \\
\hline Perciformes & Sciaenidae & Dendrophysa russellii & Densse & Indigenous & G10 & NA \\
\hline Cypriniformes & Cyprinidae & Devario gibber & Devbbe & Indigenous & G1 & LC \\
\hline Cypriniformes & Cyprinidae & Devario fangfangae & Devngf & Indigenous & G1 & LC \\
\hline Cypriniformes & Cyprinidae & Devario leptos & Devpto & Indigenous & G1 & LC \\
\hline Cypriniformes & Cyprinidae & Discherodontus ashmeadi & Dishme & Indigenous & G1 & LC \\
\hline Cypriniformes & Cyprinidae & Discherodontus schroederi & Dishro & Indigenous & G1 & LC \\
\hline Cypriniformes & Cyprinidae & Discherodontus parvus & Disrvu & Indigenous & G1 & $\mathrm{DD}$ \\
\hline Perciformes & Eleotridae & Eleotris acanthopomus & Eleant & Indigenous & G7 & NA \\
\hline
\end{tabular}




\begin{tabular}{|c|c|c|c|c|c|c|}
\hline Order & Family & Scientific Name & Short Name & Invasive Status & Guild & IUCN Category \\
\hline Perciformes & Eleotridae & Eleotris fusca & Elesca & Indigenous & G7 & LC \\
\hline Perciformes & Polynemidae & $\begin{array}{l}\text { Eleutheronema } \\
\text { tetradactylum }\end{array}$ & Eletra & Indigenous & G7 & NA \\
\hline Mugiliformes & Mugilidae & Ellochelon vaigiensis & Elligi & Indigenous & G7 & NA \\
\hline Elopiformes & Elopidae & Elops hawaiensis & Eloaie & Indigenous & G10 & NA \\
\hline Cypriniformes & Cyprinidae & Epalzeorhynchos frenatum & Epaena & Indigenous & G1 & LC \\
\hline Cypriniformes & Cyprinidae & Epalzeorhynchos munense & Epanen & Indigenous & G1 & VU \\
\hline Cypriniformes & Cyprinidae & Esomus longimana & Esongi & Indigenous & G6 & NA \\
\hline Cypriniformes & Cyprinidae & Esomus metallicus & Esotal & Indigenous & G6 & LC \\
\hline Perciformes & Gobiidae & Eugnathogobius microps & Eugcro & Indigenous & G7 & NA \\
\hline Perciformes & Polynemidae & Filimanus heptadactyla & Filpta & Indigenous & G7 & NA \\
\hline Cypriniformes & Cyprinidae & Folifer brevifilis & Folevi & Indigenous & G3 & DD \\
\hline Cyprinodontiformes & Poeciliidae & Gambusia affinis & Gamfin & Exotic & G11 & NA \\
\hline Cypriniformes & Cyprinidae & Garra theunensis & Gareun & Indigenous & G1 & LC \\
\hline Cypriniformes & Cyprinidae & Garra cambodgiensis & Garmbo & Indigenous & G1 & LC \\
\hline Cypriniformes & Cyprinidae & Garra cyrano & Garran & Indigenous & G1 & DD \\
\hline Cypriniformes & Cyprinidae & Garra fasciacauda & Garsci & Indigenous & G1 & LC \\
\hline Cypriniformes & Cyprinidae & Gibelion catla & Gibtla & Exotic & G11 & NA \\
\hline Perciformes & Gobiidae & Glossogobius aureus & Gloreu & Indigenous & G7 & LC \\
\hline Perciformes & Gobiidae & Glossogobius giuris & Glouri & Indigenous & G7 & LC \\
\hline Siluriformes & Sisoridae & $\begin{array}{l}\text { Glyptothorax } \\
\text { macromaculatus }\end{array}$ & Glycro & Indigenous & G1 & LC \\
\hline Siluriformes & Sisoridae & Glyptothorax laosensis & Glyose & Indigenous & G1 & LC \\
\hline Siluriformes & Sisoridae & Glyptothorax horai & Glyrai & Indigenous & G1 & LC \\
\hline Siluriformes & Sisoridae & Glyptothorax fuscus & Glyscu & Indigenous & G1 & NA \\
\hline
\end{tabular}




\begin{tabular}{|c|c|c|c|c|c|c|}
\hline Order & Family & Scientific Name & Short Name & Invasive Status & Guild & IUCN Category \\
\hline Perciformes & Gobiidae & Gobiopterus brachypterus & Gobach & Indigenous & G7 & NA \\
\hline Cypriniformes & Cyprinidae & Gobiobotia yuanjianensis & Gobanj & Indigenous & G1 & NA \\
\hline Cypriniformes & Cyprinidae & Gobiobotia longibarba & Gobngi & Indigenous & G1 & NA \\
\hline Anguilliformes & Muraenidae & Gymnothorax pictus & Gymctu & Indigenous & G10 & NA \\
\hline Anguilliformes & Muraenidae & Gymnothorax tile & Gymle & Indigenous & G10 & NA \\
\hline Cypriniformes & Gyrinocheilidae & Gyrinocheilus aymonieri & Gyrmon & Indigenous & G3 & LC \\
\hline Cypriniformes & Gyrinocheilidae & Gyrinocheilus pennocki & Gyrnno & Indigenous & G3 & LC \\
\hline Cypriniformes & Cyprinidae & Hampala macrolepidota & Hamcro & Indigenous & G5 & LC \\
\hline Cypriniformes & Cyprinidae & Hampala dispar & Hamspa & Indigenous & G5 & LC \\
\hline Aulopiformes & Harpadontinae & Harpadon nehereus & Harher & Indigenous & G10 & NA \\
\hline Siluriformes & Pangasiidae & Helicophagus waandersii & Heland & Indigenous & G3 & NA \\
\hline Perciformes & Helostomatidae & Helostoma temminckii & Helmmi & Indigenous & G4 & LC \\
\hline Siluriformes & Pangasiidae & Helicophagus leptorhynchus & Helpto & Indigenous & G3 & DD \\
\hline Cypriniformes & Cyprinidae & Hemibarbus labeo & Hembeo & Exotic & G11 & NA \\
\hline Siluriformes & Bagridae & Hemibagrus wyckioides & Hemcki & Indigenous & G3 & LC \\
\hline Siluriformes & Bagridae & Hemibagrus wyckii & Hemckii & Indigenous & G3 & LC \\
\hline Beloniformes & Hemiramphidae & $\begin{array}{l}\text { Hemirhamphodon } \\
\text { pogonognathus }\end{array}$ & Hemgon & Indigenous & G10 & NA \\
\hline Cypriniformes & Balitoridae & Hemimyzon tchangi & Hemhan & Indigenous & G1 & NA \\
\hline Siluriformes & Bagridae & Hemibagrus spilopterus & Hemilo & Indigenous & G3 & LC \\
\hline Siluriformes & Bagridae & Hemibagrus sp. & Hemisp & Indigenous & G3 & NA \\
\hline Siluriformes & Siluridae & Hemisilurus mekongensis & Hemkon & Indigenous & G3 & LC \\
\hline Siluriformes & Bagridae & Hemibagrus filamentus & Hemlam & Indigenous & G3 & DD \\
\hline Siluriformes & Bagridae & Hemibagrus nemurus & Hemmur & Indigenous & G3 & LC \\
\hline Cypriniformes & Balitoridae & Hemimyzon confluens & Hemnfl & Indigenous & G1 & VU \\
\hline
\end{tabular}




\begin{tabular}{|c|c|c|c|c|c|c|}
\hline Order & Family & Scientific Name & Short Name & Invasive Status & Guild & IUCN Category \\
\hline Cypriniformes & Balitoridae & Hemimyzon pengi & Hemngi & Indigenous & G1 & DD \\
\hline Siluriformes & Ariidae & Hemiarius stormii & Hemorm & Indigenous & G7 & NA \\
\hline Cypriniformes & Balitoridae & Hemimyzon papilio & Hempil & Indigenous & G1 & LC \\
\hline Siluriformes & Ariidae & Hemipimelodus borneensis & Hemrne & Indigenous & G7 & NA \\
\hline Siluriformes & Ariidae & Hemiarius verrucosus & Hemrru & Indigenous & G7 & NA \\
\hline Siluriformes & Ariidae & $\begin{array}{l}\text { Hemipimelodus } \\
\text { intermedius }\end{array}$ & Hemter & Indigenous & G7 & NA \\
\hline Cypriniformes & Cyprinidae & Henicorhynchus siamensis & Hename & Indigenous & G5 & NA \\
\hline Cypriniformes & Cyprinidae & Henicorhynchus lobatus & Henbat & Indigenous & G5 & NA \\
\hline Cypriniformes & Cyprinidae & $\begin{array}{l}\text { Henicorhynchus } \\
\text { ornatipinnis }\end{array}$ & Hennat & Indigenous & G5 & NA \\
\hline Cypriniformes & Cyprinidae & Henicorhynchus lineatus & Hennea & Indigenous & G5 & NA \\
\hline Cypriniformes & Cyprinidae & $\begin{array}{l}\text { Henicorhynchus } \\
\text { caudimaculatus }\end{array}$ & Henudi & Indigenous & G5 & NA \\
\hline Siluriformes & Bagridae & Heterobagrus bocourti & Hetcou & Indigenous & G4 & NA \\
\hline Siluriformes & Heteropneustidae & $\begin{array}{l}\text { Heteropneustes } \\
\text { kemratensis }\end{array}$ & Hetmra & Indigenous & G6 & NA \\
\hline Myliobatiformes & Dasyatidae & Himantura imbricata & Himbri & Indigenous & G10 & NA \\
\hline Myliobatiformes & Dasyatidae & Himantura undulata & Himdul & Indigenous & G10 & NA \\
\hline Myliobatiformes & Dasyatidae & Himantura krempfi & Himemp & Indigenous & G3 & NA \\
\hline Myliobatiformes & Dasyatidae & Himantura signifer & Himgni & Indigenous & G10 & EN \\
\hline Myliobatiformes & Dasyatidae & Himantura uarnak & Himrna & Indigenous & G10 & NA \\
\hline Myliobatiformes & Dasyatidae & Himantura oxyrhynchus & Himyrh & Indigenous & G10 & EN \\
\hline Cypriniformes & Balitoridae & Homaloptera indochinensis & Homdoc & Indigenous & G1 & NA \\
\hline Cypriniformes & Balitoridae & Homaloptera vulgaris & Homlga & Indigenous & G1 & NA \\
\hline Cypriniformes & Balitoridae & Homaloptera zollingeri & Homlli & Indigenous & G1 & LC \\
\hline
\end{tabular}




\begin{tabular}{|c|c|c|c|c|c|c|}
\hline Order & Family & Scientific Name & Short Name & Invasive Status & Guild & IUCN Category \\
\hline Cypriniformes & Balitoridae & Homaloptera yunnanensis & Homnna & Indigenous & G1 & LC \\
\hline Cypriniformes & Cyprinidae & Hypophthalmichthys nobilis & Hypbil & Exotic & G11 & NA \\
\hline Siluriformes & Loricariidae & Hypostomus plecostomus & Hypeco & Exotic & G3 & NA \\
\hline Cypriniformes & Cyprinidae & Hypsibarbus pierrei & Hyperr & Indigenous & G3 & DD \\
\hline Cypriniformes & Cyprinidae & Hypsibarbus lagleri & Hypgle & Indigenous & G3 & VU \\
\hline Cypriniformes & Cyprinidae & Hypsibarbus malcolmi & Hyplco & Indigenous & G3 & LC \\
\hline Cypriniformes & Cyprinidae & $\begin{array}{l}\text { Hypophthalmichthys } \\
\text { molitrix }\end{array}$ & Hyplit & Exotic & G11 & NA \\
\hline Beloniformes & Hemiramphidae & Hyporhamphus limbatus & Hypmba & Indigenous & G7 & LC \\
\hline Cypriniformes & Cyprinidae & Hypsibarbus vernayi & Hyprna & Indigenous & G3 & LC \\
\hline Beloniformes & Hemiramphidae & Hyporhamphus intermedius & Hypter & Indigenous & G7 & NA \\
\hline Cypriniformes & Cyprinidae & Hypsibarbus wetmorei & Hyptmo & Indigenous & G3 & LC \\
\hline Cypriniformes & Cyprinidae & Hypsibarbus suvattii & Hypvat & Indigenous & G3 & NA \\
\hline Perciformes & Sciaenidae & Johnius trachycephalus & Johach & Indigenous & G10 & NA \\
\hline Perciformes & Sciaenidae & Johnius belangerii & Johlan & Indigenous & G10 & NA \\
\hline Perciformes & Sciaenidae & Johnius borneensis & Johrne & Indigenous & G10 & NA \\
\hline Perciformes & Sciaenidae & Johnius carouna & Johrou & Indigenous & G10 & NA \\
\hline Siluriformes & Siluridae & Kryptopterus bicirrhis & Krycir & Indigenous & G3 & LC \\
\hline Siluriformes & Siluridae & Kryptopterus micronema & Krycro & Indigenous & G3 & NA \\
\hline Siluriformes & Siluridae & Kryptopterus cheveyi & Kryeve & Indigenous & G3 & NA \\
\hline Siluriformes & Siluridae & Kryptopterus schilbeides & Kryhil & Indigenous & G3 & NA \\
\hline Siluriformes & Siluridae & $\begin{array}{l}\text { Kryptopterus } \\
\text { palembangensis }\end{array}$ & Krylem & Indigenous & G3 & NA \\
\hline Siluriformes & Siluridae & Kryptopterus geminus & Krymin & Indigenous & G3 & LC \\
\hline Siluriformes & Siluridae & Kryptopterus limpok & Krympo & Indigenous & G3 & NA \\
\hline
\end{tabular}




\begin{tabular}{|c|c|c|c|c|c|c|}
\hline Order & Family & Scientific Name & Short Name & Invasive Status & Guild & IUCN Category \\
\hline Siluriformes & Siluridae & Kryptopterus sp. & Krypsp & Indigenous & G3 & NA \\
\hline Siluriformes & Siluridae & Kryptopterus dissitus & Kryssi & Indigenous & G3 & $\mathrm{DD}$ \\
\hline Siluriformes & Siluridae & Kryptopterus cryptopterus & Kryypt & Indigenous & G3 & NA \\
\hline Cypriniformes & Cyprinidae & Labiobarbus siamensis & Labame & Indigenous & G5 & LC \\
\hline Cypriniformes & Cyprinidae & Labeo pierrei & Laberr & Indigenous & G3 & VU \\
\hline Cypriniformes & Cyprinidae & Labeo rohita & Labhit & Exotic & G11 & NA \\
\hline Cypriniformes & Cyprinidae & Labiobarbus lineata & Labnea & Indigenous & G5 & NA \\
\hline Cypriniformes & Cyprinidae & Labeo dyocheilus & Laboch & Exotic & G11 & LC \\
\hline Cypriniformes & Cyprinidae & Labiobarbus kuhli & Labpto & Indigenous & G5 & NA \\
\hline Cypriniformes & Cyprinidae & Labeo chrysophekadion & Labrys & Indigenous & G3 & LC \\
\hline Cypriniformes & Cyprinidae & Labiobarbus sp. cf. lineata & Labsp & Indigenous & G5 & NA \\
\hline Cypriniformes & Cyprinidae & Labeo erythropterus & Labyth & Exotic & G11 & NA \\
\hline Tetraodontiformes & Tetraodontidae & Lagocephalus spadiceus & Lagadi & Indigenous & G10 & NA \\
\hline Siluriformes & Schilbeidae & Laides longibarbis & Laingi & Indigenous & G3 & LC \\
\hline Cypriniformes & Cyprinidae & Laocypris hispida & Laospi & Indigenous & G4 & $\mathrm{DD}$ \\
\hline Perciformes & Centropomidae & Lates calcarifer & Latlca & Indigenous & G10 & NA \\
\hline Cypriniformes & Cyprinidae & Leptobarbus hoeveni & Lepeve & Exotic & G11 & NA \\
\hline Cypriniformes & Cobitidae & $\begin{array}{l}\text { Lepidocephalichthys } \\
\text { hasselti }\end{array}$ & Lepsse & Indigenous & G6 & LC \\
\hline Perciformes & Trichiuridae & Lepturacanthus savala & Lepval & Indigenous & $?$ & NA \\
\hline Cypriniformes & Cyprinidae & Lobocheilos rhabdoura & Lobabd & Indigenous & G1 & LC \\
\hline Cypriniformes & Cyprinidae & Lobocheilos gracilis & Lobaci & Indigenous & G1 & NA \\
\hline Cypriniformes & Cyprinidae & Lobocheilos melanotaenia & Loblan & Indigenous & G1 & LC \\
\hline Cypriniformes & Cyprinidae & Lobocheilos davisi & Lobvis & Indigenous & G1 & NA \\
\hline Cypriniformes & Cyprinidae & Longiculter siahi & Lonahi & Indigenous & No Data & $\mathrm{DD}$ \\
\hline
\end{tabular}




\begin{tabular}{|c|c|c|c|c|c|c|}
\hline Order & Family & Scientific Name & Short Name & Invasive Status & Guild & IUCN Category \\
\hline Cypriniformes & Cyprinidae & Luciosoma bleekeri & Luceek & Indigenous & G3 & LC \\
\hline Cypriniformes & Cyprinidae & Luciocyprinus striolatus & Lucrio & Indigenous & G3 & EN \\
\hline Cypriniformes & Cyprinidae & Luciosoma setigerum & Luctig & Indigenous & G3 & DD \\
\hline Perciformes & Lutjanidae & Lutjanus johnii & Luthni & Indigenous & G10 & NA \\
\hline Perciformes & Lutjanidae & Lutjanus malabaricus & Lutlab & Indigenous & G10 & NA \\
\hline Perciformes & Lutjanidae & Lutjanus russellii & Lutsse & Indigenous & G10 & NA \\
\hline Clupeiformes & Engraulidae & Lycothrissa crocodilus & Lycoco & Indigenous & G7 & LC \\
\hline Synbranchiformes & Mastacembelidae & Macrognathus siamensis & Macame & Indigenous & G6 & LC \\
\hline Cypriniformes & Cyprinidae & $\begin{array}{l}\text { Macrochirichthys } \\
\text { macrochirus }\end{array}$ & Maccro & Indigenous & G4 & NT \\
\hline Synbranchiformes & Mastacembelidae & Macrognathus maculatus & Maccul & Indigenous & G6 & LC \\
\hline Synbranchiformes & Mastacembelidae & Macrognathus taeniagaster & Maceni & Indigenous & G6 & NA \\
\hline Perciformes & Belontiidae & Macropodus opercularis & Macerc & Exotic & G11 & LC \\
\hline Synbranchiformes & Synbranchidae & Macrotrema caligans & Maclig & Indigenous & G7 & NA \\
\hline Synbranchiformes & Mastacembelidae & $\begin{array}{l}\text { Macrognathus } \\
\text { semiocellatus }\end{array}$ & Macmio & Indigenous & G6 & LC \\
\hline Synbranchiformes & Mastacembelidae & $\begin{array}{l}\text { Macrognathus } \\
\text { circumcinctus }\end{array}$ & Macrcu & Indigenous & G6 & LC \\
\hline Perciformes & Gobiidae & Mahidolia mystacina & Mahsta & Indigenous & G10 & NA \\
\hline Synbranchiformes & Mastacembelidae & Mastacembelus armatus & Masmat & Indigenous & G5 & LC \\
\hline Synbranchiformes & Mastacembelidae & Mastacembelus favus & Masvus & Indigenous & G5 & LC \\
\hline Synbranchiformes & Mastacembelidae & $\begin{array}{l}\text { Mastacembelus } \\
\text { erythrotaenia }\end{array}$ & Masyth & Indigenous & G5 & LC \\
\hline Elopiformes & Megalopidae & Megalops cyprinoides & Megpri & Indigenous & G10 & DD \\
\hline Cypriniformes & Cyprinidae & Mekongina erythrospila & Mekyth & Indigenous & $\mathrm{G} 1$ & NT \\
\hline Cypriniformes & Cyprinidae & Metzia lineata & Metnea & Indigenous & G1 & LC \\
\hline
\end{tabular}




\begin{tabular}{|c|c|c|c|c|c|c|}
\hline Order & Family & Scientific Name & Short Name & Invasive Status & Guild & IUCN Category \\
\hline Siluriformes & Siluridae & Micronema bleekeri & Miceek & Indigenous & G3 & NA \\
\hline Siluriformes & Siluridae & Micronema cheveyi & Miceve & Indigenous & G3 & DD \\
\hline Siluriformes & Siluridae & Micronema apogon & Micogo & Indigenous & G3 & NA \\
\hline Siluriformes & Siluridae & Micronema hexapterus & Micxap & Indigenous & G3 & NA \\
\hline Cypriniformes & Cobitidae & Misgurnus anguillicaudatus & Misgui & Exotic & G11 & NA \\
\hline Synbranchiformes & Synbranchidae & Monopterus albus & Monbus & Indigenous & G6 & LC \\
\hline Tetraodontiformes & Tetraodontidae & Monotrete cochinchinensis & Monchi & Indigenous & G6 & LC \\
\hline Tetraodontiformes & Tetraodontidae & Monotrete abei & Monei & Indigenous & G3 & NA \\
\hline Perciformes & Monodactylidae & Monodactylus argenteus & Mongen & Indigenous & G10 & NA \\
\hline Tetraodontiformes & Tetraodontidae & Monotrete baileyi & Monile & Indigenous & G1 & LC \\
\hline Tetraodontiformes & Tetraodontidae & Monotrete leiurus & Moniur & Indigenous & G7 & NA \\
\hline Tetraodontiformes & Tetraodontidae & Monotrete cambodgiensis & Monmbo & Indigenous & G4 & LC \\
\hline Tetraodontiformes & Tetraodontidae & Monotrete fangi & Monngi & NA & G7 & NA \\
\hline Tetraodontiformes & Tetraodontidae & Monotrete barbatus & Monrba & Indigenous & G7 & NA \\
\hline Tetraodontiformes & Tetraodontidae & Monotrete turgidus & Monrgi & Indigenous & G1 & LC \\
\hline Tetraodontiformes & Tetraodontidae & Monotrete suvattii & Monvat & Indigenous & G4 & LC \\
\hline Mugiliformes & Mugilidae & Moolgarda pedaraki & Moodar & Indigenous & G10 & NA \\
\hline Mugiliformes & Mugilidae & Moolgarda seheli & Moohel & Indigenous & G10 & NA \\
\hline Mugiliformes & Mugilidae & Mugil cephalus & Mugpha & Indigenous & G10 & NA \\
\hline Perciformes & Gobiidae & Mugilogobius chulae & Mugula & Indigenous & G7 & LC \\
\hline Anguilliformes & Muraenesocidae & Muraenesox bagio & Murgio & Indigenous & G10 & NA \\
\hline Anguilliformes & Muraenesocidae & Muraenesox cinereus & Murner & Indigenous & G10 & NA \\
\hline Siluriformes & Bagridae & Mystus albolineatus & Mysbol & Indigenous & G4 & LC \\
\hline Siluriformes & Bagridae & Mystus micracanthus & Myscra & Indigenous & G4 & NA \\
\hline
\end{tabular}




\begin{tabular}{|c|c|c|c|c|c|c|}
\hline Order & Family & Scientific Name & Short Name & Invasive Status & Guild & IUCN Category \\
\hline Cypriniformes & Cyprinidae & Mystacoleucus greenwayi & Myseen & Indigenous & $\mathrm{G} 1$ & LC \\
\hline Siluriformes & Bagridae & Mystus rhegma & Mysegm & Indigenous & G4 & DD \\
\hline Cypriniformes & Cyprinidae & Mystacoleucus chilopterus & Mysilo & Indigenous & G1 & LC \\
\hline Siluriformes & Bagridae & Mystus wolffii & Myslff & Indigenous & G4 & NA \\
\hline Siluriformes & Bagridae & Mystus cf wolffi & MysIffi & Indigenous & G4 & NA \\
\hline Siluriformes & Bagridae & Mystus gulio & Myslio & Indigenous & G4 & LC \\
\hline Siluriformes & Bagridae & Mystus multiradiatus & Myslti & Indigenous & G4 & LC \\
\hline Siluriformes & Bagridae & Mystus nemurus & Mysmur & Indigenous & G3 & NA \\
\hline Siluriformes & Bagridae & Mystus singaringan & Mysnga & Indigenous & G4 & LC \\
\hline Cypriniformes & Cyprinidae & Mystacoleucus lepturus & Mysptu & Indigenous & G1 & VU \\
\hline Cypriniformes & Cyprinidae & Mystacoleucus marginatus & Mysrgi & Indigenous & G1 & LC \\
\hline Cypriniformes & Cyprinidae & Mystacoleucus atridorsalis & Mysrid & Indigenous & G1 & LC \\
\hline Siluriformes & Bagridae & Mystus atrifasciatus & Mysrif & Indigenous & G4 & LC \\
\hline Siluriformes & Bagridae & Mystus mysticetus & Myssti & Indigenous & G4 & LC \\
\hline Cypriniformes & Cyprinidae & Mystacoleucus ectypus & Mystyp & Indigenous & G1 & LC \\
\hline Perciformes & Nandidae & Nandus nebulosus & Nanbul & Indigenous & G7 & LC \\
\hline Perciformes & Nandidae & Nandus oxyrhynchus & Nanyrh & Indigenous & G4 & LC \\
\hline Cypriniformes & Balitoridae & Nemacheilus pallidus & Nemlli & Indigenous & G1 & LC \\
\hline Cypriniformes & Balitoridae & Nemacheilus longistriatus & Nemngi & Indigenous & G1 & LC \\
\hline Clupeiformes & Clupeidae & Nematalosa nasus & Nemsus & Indigenous & G7 & NA \\
\hline Cypriniformes & Balitoridae & Nemacheilus masyae & Nemsya & Indigenous & G1 & DD \\
\hline Cypriniformes & Cyprinidae & Neolissochilus blanci & Neoanc & Indigenous & G1 & NT \\
\hline Cypriniformes & Cyprinidae & Neobarynotus microlepis & Neocro & Exotic & G11 & DD \\
\hline Cypriniformes & Cyprinidae & Neolissochilus stracheyi & Neorac & Indigenous & $\mathrm{G} 1$ & LC \\
\hline
\end{tabular}




\begin{tabular}{|c|c|c|c|c|c|c|}
\hline Order & Family & Scientific Name & Short Name & Invasive Status & Guild & IUCN Category \\
\hline Cypriniformes & Cyprinidae & Neolissochilus soroides & Neoroi & Indigenous & G1 & NA \\
\hline Siluriformes & Ariidae & Netuma thalassinus & Netala & Indigenous & G7 & NA \\
\hline Siluriformes & Ariidae & Netuma bilineatus & Netlin & Indigenous & G7 & NA \\
\hline Perciformes & Sciaenidae & Nibea soldado & Niblda & Indigenous & G10 & NA \\
\hline Osteoglossiformes & Notopteridae & Notopterus notopterus & Nottop & Indigenous & G5 & LC \\
\hline Perciformes & Gobiidae & Odontamblyopus tenuis & Odonui & Indigenous & G10 & NA \\
\hline Perciformes & Odontobutidae & Odontobutis aurarmus & Odorar & Indigenous & G4 & NA \\
\hline Siluriformes & Siluridae & Ompok siluroides & Omplur & NA & G4 & NA \\
\hline Siluriformes & Siluridae & Ompok hypophthalmus & Omppop & Indigenous & G4 & NA \\
\hline Cypriniformes & Cyprinidae & Onychostoma meridionale & Onyrid & Indigenous & G1 & LC \\
\hline Cypriniformes & Cyprinidae & Onychostoma gerlachi & Onyrla & Indigenous & G1 & NA \\
\hline Cypriniformes & Cyprinidae & Onychostoma fusiforme & Onysif & Indigenous & G1 & LC \\
\hline Synbranchiformes & Synbranchidae & Ophisternon bengalense & Ophnga & Indigenous & G7 & NA \\
\hline Perciformes & Eleotridae & Ophiocara porocephala & Ophroc & Indigenous & G7 & LC \\
\hline Anguilliformes & Ophichthidae & Ophichthus rutidoderma & Ophtid & Indigenous & G10 & NA \\
\hline Clupeiformes & Clupeidae & Opisthopterus tardoore & Opirdo & Indigenous & G10 & NA \\
\hline Cypriniformes & Cyprinidae & Opsarius pulchellus & Opslch & Indigenous & G1 & LC \\
\hline Cypriniformes & Cyprinidae & Opsarius koratensis & Opsrat & Indigenous & G1 & LC \\
\hline Cypriniformes & Cyprinidae & Opsarius caudiocellatus & Opsudi & Indigenous & G1 & NA \\
\hline Perciformes & Cichlidae & Oreochromis niloticus & Orelot & Exotic & G11 & NA \\
\hline Perciformes & Cichlidae & Oreochromis aureus & Orereu & Exotic & G11 & NA \\
\hline Cypriniformes & Cyprinidae & Oreichthys parvus & Orervu & Indigenous & G1 & DD \\
\hline Perciformes & Cichlidae & Oreochromis mossambicus & Oressa & Exotic & G11 & NA \\
\hline Beloniformes & Adrianichthyidae & Oryzias pectoralis & Orycto & Indigenous & G6 & DD \\
\hline
\end{tabular}




\begin{tabular}{|c|c|c|c|c|c|c|}
\hline Order & Family & Scientific Name & Short Name & Invasive Status & Guild & IUCN Category \\
\hline Beloniformes & Adrianichthyidae & Oryzias minutillus & Orynut & Indigenous & G6 & LC \\
\hline Aulopiformes & Synodontidae & $\begin{array}{l}\text { Osmerus nelereus (Ca } \\
\text { Khoai) }\end{array}$ & Osmere & NA & G10 & NA \\
\hline Perciformes & Osphronemidae & Osphronemus exodon & Ospodo & Indigenous & G1 & VU \\
\hline Perciformes & Osphronemidae & Osphronemus goramy & Ospram & Indigenous & G1 & LC \\
\hline Cypriniformes & Cyprinidae & Osteochilus waandersii & Ostand & Indigenous & G1 & LC \\
\hline Cypriniformes & Cyprinidae & Osteochilus microcephalus & Ostcro & Indigenous & G5 & LC \\
\hline Cypriniformes & Cyprinidae & Osteochilus schlegeli & Osthle & Indigenous & G3 & NA \\
\hline Cypriniformes & Cyprinidae & Osteochilus melanopleura & Ostlan & Indigenous & G3 & LC \\
\hline Siluriformes & Ariidae & Osteogeneiosus militaris & Ostlit & Indigenous & G7 & NA \\
\hline Cypriniformes & Cyprinidae & Osteochilus enneaporus & Ostnea & Indigenous & G5 & NA \\
\hline Cypriniformes & Cyprinidae & Osteochilus lini & Ostni & Indigenous & G5 & LC \\
\hline Cypriniformes & Cyprinidae & Osteochilus hasselti & Ostsse & Indigenous & G5 & NA \\
\hline Perciformes & Sciaenidae & Otolithes ruber & Otober & NA & G10 & NA \\
\hline Perciformes & Sciaenidae & Otolithoides pama & Otoma & Indigenous & G10 & NA \\
\hline Cypriniformes & Cyprinidae & Oxygaster pointoni & Oxyint & Indigenous & G3 & VU \\
\hline Perciformes & Eleotridae & Oxyeleotris marmorata & Oxyrmo & Indigenous & G5 & LC \\
\hline Siluriformes & Pangasiidae & Pangasius djambal & Panamb & Exotic & G11 & NA \\
\hline Siluriformes & Pangasiidae & Pangasius bocourti & Pancou & Indigenous & G2 & LC \\
\hline Siluriformes & Pangasiidae & Pangasius macronema & Pancro & Indigenous & G3 & LC \\
\hline Perciformes & Sciaenidae & Panna microdon & Pancrod & Indigenous & G10 & NA \\
\hline Siluriformes & Pangasiidae & Pangasius krempfi & Panemp & Indigenous & G8 & VU \\
\hline Cypriniformes & Cobitidae & Pangio myersi & Paners & Indigenous & G4 & LC \\
\hline Siluriformes & Pangasiidae & Pangasius pleurotaenia & Paneur & Indigenous & G3 & NA \\
\hline Siluriformes & Pangasiidae & Pangasianodon gigas & Pangas & Indigenous & $\mathrm{G} 2$ & CR \\
\hline
\end{tabular}




\begin{tabular}{|c|c|c|c|c|c|c|}
\hline Order & Family & Scientific Name & Short Name & Invasive Status & Guild & IUCN Category \\
\hline Siluriformes & Pangasiidae & Pangasius sp. & Pangsp & Indigenous & G3 & NA \\
\hline Cypriniformes & Cobitidae & Pangio anguillaris & Pangui & Indigenous & G4 & NA \\
\hline Siluriformes & Pangasiidae & Pangasius micronemus & Panicr & Indigenous & G3 & NA \\
\hline Siluriformes & Pangasiidae & Pangasius mekongensis & Pankon & Indigenous & $\mathrm{G} 2$ & LC \\
\hline Cypriniformes & Cobitidae & Pangio filinaris & Panlin & Indigenous & G4 & NA \\
\hline Cypriniformes & Cobitidae & Pangio oblonga & Panlon & Indigenous & G4 & NA \\
\hline Siluriformes & Pangasiidae & Pangasius polyuranodon & Panlyu & Exotic & G11 & LC \\
\hline Siluriformes & Pangasiidae & Pangasius conchophilus & Pannch & Indigenous & G2 & LC \\
\hline Siluriformes & Pangasiidae & Pangasius pangasius & Pannga & Exotic & G11 & NA \\
\hline Siluriformes & Pangasiidae & Pangasius sanitwongsei & Pannit & Indigenous & $\mathrm{G} 2$ & $\mathrm{CR}$ \\
\hline Siluriformes & Pangasiidae & Pangasius elongatus & Panong & Indigenous & G8 & DD \\
\hline Siluriformes & Pangasiidae & $\begin{array}{l}\text { Pangasianodon } \\
\text { hypophthalmus }\end{array}$ & Panpop & Indigenous & G2 & EN \\
\hline Siluriformes & Pangasiidae & Pangasius larnaudii & Panrna & Indigenous & G2 & LC \\
\hline Cypriniformes & Cobitidae & Pangio fusca & Pansca & Indigenous & G4 & DD \\
\hline Siluriformes & Pangasiidae & Pangasius nasutus & Pansut & Indigenous & $?$ & NA \\
\hline Siluriformes & Sisoridae & $\begin{array}{l}\text { Pareuchiloglanis } \\
\text { gracilicaudata }\end{array}$ & Paraci & Indigenous & G1 & NA \\
\hline Cypriniformes & Cyprinidae & Parachela siamensis & Parame & Indigenous & G4 & LC \\
\hline Perciformes & Chandidae & Parambassis siamensis & Paramen & Indigenous & G5 & LC \\
\hline Cypriniformes & Cyprinidae & Parachela maculicauda & Parcul & Indigenous & G4 & LC \\
\hline Perciformes & Chandidae & Parambassis wolffi & Parlff & Indigenous & G4 & NA \\
\hline Pleuronectiformes & Cynoglossidae & Paraplagusia bilineata & Parlin & Indigenous & G10 & NA \\
\hline Cypriniformes & Cyprinidae & Parachela williaminae & Parlli & Indigenous & G4 & LC \\
\hline Perciformes & Chandidae & Parambassis apogonoides & Parogo & Indigenous & G4 & LC \\
\hline
\end{tabular}




\begin{tabular}{|c|c|c|c|c|c|c|}
\hline Order & Family & Scientific Name & Short Name & Invasive Status & Guild & IUCN Category \\
\hline Cypriniformes & Cyprinidae & Paralaubuca typus & Parpus & Indigenous & G4 & LC \\
\hline Cypriniformes & Cyprinidae & Paralaubuca harmandi & Parrma & Indigenous & G4 & LC \\
\hline Cypriniformes & Cyprinidae & Paralaubuca barroni & Parrro & Indigenous & G4 & LC \\
\hline Cypriniformes & Cyprinidae & Paralaubuca riveroi & Parver & Indigenous & G4 & LC \\
\hline Cypriniformes & Cyprinidae & Parachela oxygastroides & Paryga & Indigenous & G4 & LC \\
\hline Siluriformes & Sisoridae & Pareuchiloglanis myzostoma & Parzos & Indigenous & G1 & NA \\
\hline Myliobatiformes & Dasyatidae & Pastinachus sephen & Pasphe & Indigenous & G7 & DD \\
\hline Perciformes & Gerreidae & Pentaprion longimana & Penngi & Indigenous & G10 & NA \\
\hline Perciformes & Gobiidae & $\begin{array}{l}\text { Periophthalmodon } \\
\text { septemradiatus }\end{array}$ & Perpte & Indigenous & G7 & NA \\
\hline Cypriniformes & Balitoridae & Physoschistura meridionalis & Phyrid & Indigenous & G1 & NA \\
\hline Characiformes & Characidae & Piaractus brachypomus & Piaach & Exotic & G11 & NA \\
\hline Anguilliformes & Ophichthidae & Pisodonophis boro & Pisro & Indigenous & G8 & NA \\
\hline Scorpaeniformes & Platycephalidae & Platycephalus indicus & Pladic & Indigenous & G10 & NA \\
\hline Siluriformes & Plotosidae & Plotosus lineatus & Plonea & Indigenous & G10 & NA \\
\hline Siluriformes & Plotosidae & Plotosus canius & Ploniu & Indigenous & G7 & NA \\
\hline Perciformes & Polynemidae & Polynemus melanochir & Pollan & Indigenous & G7 & LC \\
\hline Perciformes & Polynemidae & Polynemus multifilis & Pollti & Indigenous & G7 & NA \\
\hline Perciformes & Polynemidae & Polynemus longipectoralis & Polngi & Indigenous & G7 & NA \\
\hline Perciformes & Polynemidae & Polynemus borneensis & Polrne & Indigenous & G7 & NA \\
\hline Perciformes & Polynemidae & Polynemus aquilonaris & Poluil & Indigenous & G7 & LC \\
\hline Cypriniformes & Cyprinidae & Poropuntius cf.laonensis & Por.la & Indigenous & $?$ & NA \\
\hline Cypriniformes & Cyprinidae & $\begin{array}{l}\text { Poropuntius } \\
\text { huangchuchieni }\end{array}$ & Porang & Indigenous & G1 & NA \\
\hline Cypriniformes & Cyprinidae & Poropuntius deauratus & Poraur & Indigenous & G1 & EN \\
\hline
\end{tabular}




\begin{tabular}{|c|c|c|c|c|c|c|}
\hline Order & Family & Scientific Name & Short Name & Invasive Status & Guild & IUCN Category \\
\hline Cypriniformes & Cyprinidae & $\begin{array}{l}\text { Poropuntius sp. Cf. } \\
\text { deauratus }\end{array}$ & Poraura & Indigenous & $?$ & NA \\
\hline Cypriniformes & Cyprinidae & Poropuntius speleops & Porele & Indigenous & G1 & VU \\
\hline Cypriniformes & Cyprinidae & Poropuntius exigua & Porigu & Indigenous & G1 & NA \\
\hline Cypriniformes & Cyprinidae & Poropuntius solitus & Porlit & Indigenous & G1 & EN \\
\hline Cypriniformes & Cyprinidae & Poropuntius bolovenensis & Porlov & Indigenous & G1 & EN \\
\hline Cypriniformes & Cyprinidae & Poropuntius consternans & Pornst & Indigenous & $\mathrm{G} 1$ & EN \\
\hline Cypriniformes & Cyprinidae & Poropuntius bantamensis & Pornta & Indigenous & G1 & LC \\
\hline Cypriniformes & Cyprinidae & Poropuntius laoensis & Poroen & Indigenous & G1 & LC \\
\hline Cypriniformes & Cyprinidae & Poropuntius carinatus & Porrin & Indigenous & G1 & LC \\
\hline Rhinopristiformes & Pristidae & Pristis microdon & Pricro & Indigenous & G10 & NA \\
\hline Perciformes & Nandidae & Pristolepis fasciata & Prisci & Indigenous & G4 & LC \\
\hline Cypriniformes & Cyprinidae & Probarbus labeamajor & Probea & Indigenous & $\mathrm{G} 2$ & EN \\
\hline Cypriniformes & Cyprinidae & Probarbus labeaminor & Probean & Indigenous & $\mathrm{G} 2$ & NT \\
\hline Cypriniformes & Cyprinidae & Probarbus jullieni & Prolli & Indigenous & $\mathrm{G} 2$ & EN \\
\hline Siluriformes & Bagridae & Pseudomystus siamensis & Pseame & Indigenous & G3 & LC \\
\hline Siluriformes & Bagridae & Pseudomystus stenomus & Pseeno & Indigenous & G3 & NA \\
\hline Siluriformes & Sisoridae & Pseudecheneis sulcatoides & Pselca & Indigenous & G1 & NA \\
\hline Siluriformes & Sisoridae & Pseudecheneis immaculata & Psemac & Indigenous & G1 & DD \\
\hline Siluriformes & Bagridae & Pseudomystus bomboides & Psembo & Indigenous & G3 & DD \\
\hline Cypriniformes & Cyprinidae & Pseudorasbora parva & Pserva & Exotic & G11 & LC \\
\hline Cypriniformes & Cyprinidae & Pseudohemiculter dispar & Psespa & Indigenous & G3 & NA \\
\hline Siluriformes & Loricariidae & $\begin{array}{l}\text { Pterygoplichthys } \\
\text { disjunctivus }\end{array}$ & Ptesju & Exotic & G11 & NA \\
\hline Cypriniformes & Cyprinidae & Puntioplites waandersi & Punand & Indigenous & G3 & LC \\
\hline
\end{tabular}




\begin{tabular}{|c|c|c|c|c|c|c|}
\hline Order & Family & Scientific Name & Short Name & Invasive Status & Guild & IUCN Category \\
\hline Cypriniformes & Cyprinidae & Puntius brevis & Punevi & Indigenous & G6 & LC \\
\hline Cypriniformes & Cyprinidae & Puntius spilopterus & Punilo & Indigenous & G4 & NA \\
\hline Cypriniformes & Cyprinidae & Puntioplites falcifer & Punlci & Indigenous & G3 & LC \\
\hline Cypriniformes & Cyprinidae & Puntioplites bulu & Punlu & Indigenous & G3 & DD \\
\hline Cypriniformes & Cyprinidae & Puntius binotatus & Punnot & Indigenous & G4 & NA \\
\hline Cypriniformes & Cyprinidae & Puntioplites proctozysron & Punoct & Indigenous & G3 & NA \\
\hline Cypriniformes & Cyprinidae & Puntius stoliczkanus & Punoli & Indigenous & G4 & NA \\
\hline Cypriniformes & Cyprinidae & Puntius rhombeus & Punomb & Indigenous & G4 & NA \\
\hline Cypriniformes & Cyprinidae & Puntius orphoides & Punpho & Indigenous & G5 & NA \\
\hline Cypriniformes & Cyprinidae & Puntius partipentazona & Punrti & Indigenous & G4 & NA \\
\hline Cypriniformes & Cyprinidae & Racoma grisea & Racise & Indigenous & G1 & NA \\
\hline Cypriniformes & Cyprinidae & Racoma lantsangensis & Racnts & Indigenous & G1 & NA \\
\hline Cypriniformes & Cyprinidae & Raiamas guttatus & Raitta & Indigenous & G1 & LC \\
\hline Perciformes & Scombridae & Rastrelliger brachysoma & Rasach & Indigenous & G10 & NA \\
\hline Cypriniformes & Cyprinidae & Rasbora hobelmani & Rasbel & Indigenous & G4 & NA \\
\hline Cypriniformes & Cyprinidae & Rasbora rubrodorsalis & Rasbro & Indigenous & G4 & LC \\
\hline Cypriniformes & Cyprinidae & Rasbora myersi & Rasers & Indigenous & G4 & NA \\
\hline Cypriniformes & Cyprinidae & Rasbora trilineata & Rasili & Indigenous & G4 & LC \\
\hline Cypriniformes & Cyprinidae & Rasbora spilocerca & Rasilo & Indigenous & G4 & LC \\
\hline Cypriniformes & Cyprinidae & Rasbora palustris & Raslus & Indigenous & G4 & NA \\
\hline Perciformes & Scombridae & Rastrelliger kanagurta & Rasnag & Indigenous & G10 & NA \\
\hline Cypriniformes & Cyprinidae & Rasbora septentrionalis & Raspte & Indigenous & G4 & DD \\
\hline Cypriniformes & Cyprinidae & Rasbora borapetensis & Rasrap & Indigenous & G4 & LC \\
\hline Cypriniformes & Cyprinidae & Rasbora atridorsalis & Rasrid & Indigenous & G4 & LC \\
\hline
\end{tabular}




\begin{tabular}{|c|c|c|c|c|c|c|}
\hline Order & Family & Scientific Name & Short Name & Invasive Status & Guild & IUCN Category \\
\hline Cypriniformes & Cyprinidae & Rasbora tornieri & Rasrni & Indigenous & G4 & LC \\
\hline Cypriniformes & Cyprinidae & Rasbora aurotaenia & Rasrot & Indigenous & G4 & LC \\
\hline Cypriniformes & Cyprinidae & Rasbora dorsinotata & Rasrsi & Indigenous & G4 & NA \\
\hline Cypriniformes & Cyprinidae & $\begin{array}{l}\text { Rasbora spp. Thai Catch/ } \\
\text { Mkt }\end{array}$ & Rasspp & Indigenous & G4 & NA \\
\hline Cypriniformes & Cyprinidae & Rasbora pauciperforata & Rasuci & Indigenous & G4 & LC \\
\hline Cypriniformes & Cyprinidae & Rasbora paviei & Rasvie & Indigenous & G4 & NA \\
\hline Perciformes & Callionymidae & Repomucenus fluviatilis & Repuvi & Indigenous & G10 & NA \\
\hline Perciformes & Gobiidae & Rhinogobius maculicervix & Rhicul & Indigenous & G1 & DD \\
\hline Perciformes & Gobiidae & Rhinogobius taenigena & Rhieni & Indigenous & G1 & LC \\
\hline Perciformes & Gobiidae & Rhinogobius sp"khmer" & Rhispk & NA & $\mathrm{G} 1$ & NA \\
\hline Clupeiformes & Clupeidae & Sardinella gibbosa & Sarbbo & Indigenous & G10 & NA \\
\hline Aulopiformes & Synodontidae & Saurida undosquamis & Saudos & Indigenous & G10 & NA \\
\hline Cypriniformes & Cyprinidae & $\begin{array}{l}\text { Scaphiodonichthys } \\
\text { acanthopterus }\end{array}$ & Scaant & Indigenous & G1 & LC \\
\hline Cypriniformes & Cyprinidae & Scaphognathops stejnegeri & Scaejn & Indigenous & G3 & LC \\
\hline Perciformes & Scatophagidae & Scatophagus argus & Scagus & Indigenous & G7 & LC \\
\hline Cypriniformes & Cyprinidae & $\begin{array}{l}\text { Scaphognathops } \\
\text { bandanensis }\end{array}$ & Scanda & Indigenous & G3 & VU \\
\hline Perciformes & Gobiidae & Scartelaos histophorus & Scasto & Indigenous & G10 & NA \\
\hline Cypriniformes & Balitoridae & Schistura crabro & Schabr & Indigenous & G1 & DD \\
\hline Cypriniformes & Balitoridae & Schistura quaesita & Schaes & Indigenous & G1 & NA \\
\hline Cypriniformes & Balitoridae & Schistura aramis & Schami & Indigenous & G1 & DD \\
\hline Cypriniformes & Balitoridae & Schistura breviceps & Schevi & Indigenous & G1 & DD \\
\hline Cypriniformes & Balitoridae & Schistura sigillata & Schgil & Indigenous & G1 & DD \\
\hline Cypriniformes & Balitoridae & Schistura kohchangensis & Schhch & Indigenous & G1 & NA \\
\hline
\end{tabular}




\begin{tabular}{|c|c|c|c|c|c|c|}
\hline Order & Family & Scientific Name & Short Name & Invasive Status & Guild & IUCN Category \\
\hline Cypriniformes & Balitoridae & Schistura athos & Schhos & Indigenous & G1 & LC \\
\hline Cypriniformes & Balitoridae & Schistura punctifasciata & Schnct & Indigenous & G1 & NA \\
\hline Cypriniformes & Balitoridae & Schistura procera & Schoce & Indigenous & G1 & LC \\
\hline Cypriniformes & Balitoridae & Schistura coruscans & Schrus & Indigenous & G1 & DD \\
\hline Cypriniformes & Balitoridae & Schistura cataracta & Schtar & Indigenous & G1 & LC \\
\hline Cypriniformes & Balitoridae & Schistura laterivittata & Schter & Indigenous & G1 & NA \\
\hline Cypriniformes & Balitoridae & Schistura latifasciata & Schtif & Indigenous & $\mathrm{G} 1$ & NA \\
\hline Cypriniformes & Balitoridae & Schistura daubentoni & Schube & Indigenous & $\mathrm{G} 1$ & LC \\
\hline Osteoglossiformes & Osteoglossidae & Scleropages formosus & Sclrmo & Indigenous & G1 & EN \\
\hline Perciformes & Scombridae & $\begin{array}{l}\text { Scomberomorus } \\
\text { commerson }\end{array}$ & Scomme & NA & G10 & NA \\
\hline Perciformes & Scombridae & Scomberomorus sinensis & Sconen & Indigenous & G10 & DD \\
\hline Perciformes & Carangidae & Selaroides leptolepis & Selpto & Indigenous & G10 & NA \\
\hline Cypriniformes & Cobitidae & Serpenticobitis zonata & Sernat & Indigenous & G1 & DD \\
\hline Cypriniformes & Cobitidae & Serpenticobitis cingulata & Serngu & Indigenous & G1 & VU \\
\hline Cypriniformes & Cobitidae & Serpenticobitis octozona & Sertoz & Indigenous & $\mathrm{G} 1$ & DD \\
\hline Clupeiformes & Engraulidae & Setipinna breviceps & Setevi & Indigenous & G10 & NA \\
\hline Clupeiformes & Engraulidae & Setipinna melanochir & Setlan & Indigenous & G7 & NA \\
\hline Clupeiformes & Engraulidae & Setipinna taty & Setty & Indigenous & G10 & NA \\
\hline Cypriniformes & Balitoridae & Sewellia diardi & Seward & Indigenous & G1 & $\mathrm{DD}$ \\
\hline Perciformes & Siganidae & Siganus guttatus & Sigtta & Indigenous & G10 & NA \\
\hline Cypriniformes & Cyprinidae & Sikukia flavicaudata & Sikavi & Indigenous & G4 & DD \\
\hline Cypriniformes & Cyprinidae & Sikukia gudgeri & Sikdge & Indigenous & G4 & DD \\
\hline Cypriniformes & Cyprinidae & Sikukia stejnegeri & Sikejn & Indigenous & G4 & LC \\
\hline Perciformes & Sillaginidae & Sillago aeolus & Silolu & Indigenous & G10 & NA \\
\hline
\end{tabular}




\begin{tabular}{|c|c|c|c|c|c|c|}
\hline Order & Family & Scientific Name & Short Name & Invasive Status & Guild & IUCN Category \\
\hline Siluriformes & Siluridae & Silurichthys hasseltii & Silsse & Indigenous & G1 & NA \\
\hline Cypriniformes & Cyprinidae & Sinilabeo yunnanensis & Sinnna & Indigenous & G3 & NA \\
\hline Cypriniformes & Cyprinidae & Sinilabeo cirrhinoides & Sinrrh & Indigenous & G3 & NA \\
\hline Cypriniformes & Cyprinidae & Sinilabeo discognathoides & Sinsco & Indigenous & G3 & NA \\
\hline Scorpaeniformes & Platycephalidae & Sorsogona tuberculata & Sorber & Indigenous & G10 & NA \\
\hline Carcharhiniformes & Sphyrnidae & Sphyrna lewini & Sphwin & Indigenous & G10 & NA \\
\hline Perciformes & Sphyraenidae & Sphyraena sp. & Sphysp & Indigenous & G10 & NA \\
\hline Perciformes & Gobiidae & $\begin{array}{l}\text { Stigmatogobius } \\
\text { pleurostigma }\end{array}$ & Stieur & Indigenous & G7 & NA \\
\hline Clupeiformes & Engraulidae & Stolephorus dubiosus & Stobio & Indigenous & G10 & NA \\
\hline Clupeiformes & Engraulidae & Stolephorus baganensis & Stogan & Indigenous & G10 & NA \\
\hline Clupeiformes & Engraulidae & Stolephorus chinensis & Stoine & Indigenous & G10 & NA \\
\hline Clupeiformes & Engraulidae & Stolephorus commersonii & Stomme & Indigenous & G10 & NA \\
\hline Clupeiformes & Engraulidae & Stolephorus insularis & Stosul & Indigenous & G10 & NA \\
\hline Beloniformes & Belonidae & Strongylura incisa & Strcis & Indigenous & G10 & NA \\
\hline Beloniformes & Belonidae & Strongylura leiura & Striur & Indigenous & G10 & NA \\
\hline Osmeriformes & Salangidae & Sundasalanx mekongensis & Sunkon & Indigenous & G3 & LC \\
\hline Pleuronectiformes & Soleidae & Synaptura commersonnii & Synmme & Indigenous & G3 & NA \\
\hline Pleuronectiformes & Soleidae & Synaptura marginata & Synrgi & Indigenous & G3 & NA \\
\hline Cypriniformes & Cyprinidae & Systomus johorensis & Syshor & Indigenous & G4 & NA \\
\hline Perciformes & Gobiidae & Taenioides gracilis & Taeaci & Indigenous & G7 & NA \\
\hline Clupeiformes & Clupeidae & Tenualosa thibaudeaui & Teniba & Indigenous & G3 & VU \\
\hline Clupeiformes & Clupeidae & Tenualosa toli & Tenli & Indigenous & G10 & NA \\
\hline Perciformes & Terapontidae & Terapon theraps & Terera & Indigenous & G10 & LC \\
\hline Perciformes & Terapontidae & Terapon jarbua & Terrbu & Indigenous & G10 & LC \\
\hline
\end{tabular}




\begin{tabular}{|c|c|c|c|c|c|c|}
\hline Order & Family & Scientific Name & Short Name & Invasive Status & Guild & IUCN Category \\
\hline Perciformes & Terapontidae & Terapon puta & Terta & Indigenous & G10 & NA \\
\hline Tetraodontiformes & Tetraodontidae & Tetraodon nigroviridis & Tetgro & Indigenous & G7 & NA \\
\hline Tetraodontiformes & Tetraodontidae & Tetraodon fluviatilis & Tetuvi & Indigenous & G7 & NA \\
\hline Cypriniformes & Cyprinidae & Thynnichthys thynnoides & Thyynn & Indigenous & G4 & LC \\
\hline Cypriniformes & Cyprinidae & Tor ater & Torer & Indigenous & G1 & VU \\
\hline Cypriniformes & Cyprinidae & Tor polylepis & Torlyl & Indigenous & G1 & DD \\
\hline Cypriniformes & Cyprinidae & Tor tambroides & Tormbr & Indigenous & G1 & DD \\
\hline Cypriniformes & Cyprinidae & Tor tambra & Tormbra & Indigenous & G1 & DD \\
\hline Cypriniformes & Cyprinidae & Tor sinensis & Tornen & Indigenous & G1 & DD \\
\hline Cypriniformes & Cyprinidae & Tor laterivittatus & Torter & Indigenous & G1 & DD \\
\hline Perciformes & Toxotidae & Toxotes chatareus & Toxata & Indigenous & G7 & NA \\
\hline Perciformes & Toxotidae & Toxotes microlepis & Toxcro & Indigenous & G7 & LC \\
\hline Perciformes & Carangidae & Trachurus sp. & Tracsp & Indigenous & G10 & NA \\
\hline Perciformes & Osphronemidae & Trichogaster microlepis & Tricro & Indigenous & G6 & LC \\
\hline Perciformes & Osphronemidae & Trichogaster pectoralis & Tricto & Indigenous & G6 & LC \\
\hline Perciformes & Osphronemidae & Trichogaster leerii & Trieri & Indigenous & G6 & NT \\
\hline Perciformes & Belontiidae & Trichopsis schalleri & Trihal & Indigenous & G6 & LC \\
\hline Perciformes & Osphronemidae & Trichogaster trichopterus & Triich & Indigenous & G6 & LC \\
\hline Cypriniformes & Cyprinidae & Trigonostigma espei & Tripei & Indigenous & G4 & LC \\
\hline Perciformes & Trichiuridae & Trichiurus lepturus & Triptu & Indigenous & G10 & NA \\
\hline Perciformes & Belontiidae & Trichopsis spp. & Trispp & Indigenous & G6 & NA \\
\hline Perciformes & Belontiidae & Trichopsis vittata & Tritta & Indigenous & G6 & LC \\
\hline Cypriniformes & Cyprinidae & $\begin{array}{l}\text { Troglocyclocheilus } \\
\text { khammouanensis }\end{array}$ & Troamm & Indigenous & $?$ & VU \\
\hline Pleuronectiformes & Soleidae & Typhlachirus elongatus & Typong & Indigenous & G7 & NA \\
\hline
\end{tabular}




\begin{tabular}{|c|c|c|c|c|c|c|}
\hline Order & Family & Scientific Name & Short Name & Invasive Status & Guild & IUCN Category \\
\hline Cypriniformes & Balitoridae & Vanmanenia serrilineata & Vanrri & Indigenous & $\mathrm{G} 1$ & DD \\
\hline Siluriformes & Siluridae & Wallago micropogon & Walcro & Indigenous & G3 & $\mathrm{DD}$ \\
\hline Siluriformes & Siluridae & Wallago leerii & Waleri & Exotic & G11 & NA \\
\hline Siluriformes & Siluridae & Wallago attu & Waltu & Indigenous & G3 & NT \\
\hline Beloniformes & Belonidae & Xenentodon cancila & Xennci & Indigenous & G5 & LC \\
\hline Beloniformes & Belonidae & Xenentodon canciloides & Xenncil & Indigenous & G5 & LC \\
\hline Pleuronectiformes & Soleidae & Zebrias zebra & Zebbra & Indigenous & G10 & NA \\
\hline Beloniformes & Hemiramphidae & Zenarchopterus ectuntio & Zentun & Indigenous & G7 & NA \\
\hline
\end{tabular}




\section{Annex 5: Samples in Each Cluster}

\begin{tabular}{|c|c|}
\hline Cluster & Sample Members \\
\hline 1 & $\begin{array}{l}\text { "CKD07" "CKT14" "CKT11" "LBX07" "LBX08" "LBX09" "LBX10" "LBX11" "LBX12" "LBX13" } \\
\text { "LBX14" "LBX17" "LBX18" "LPB08" "LPB09" "LPB10" "LPB11" "LPB12" "LPB13" "LPB14" } \\
\text { "LPB17" "LPB18" "LPO08" "LPO09" "LPO10" "LPO13" "LPO14" "LPO17" "LPO18" "LVT08" } \\
\text { "LVT09" "LVT11" "LVT12" "LVT14" "LVT17" "LVT18" "TCK07" "TCK08" "TCK09" "TCK11" } \\
\text { "TCK12" "TCK13" "TCK18" "TKR07" "TKR08" "TKR09" "TKR11" "TKR12" "TKR13" "TKR17" } \\
\text { "TKR18" "TSK11" "TSK17" "TUT07" "TUT08" "TUT09" "TUT11" "TUT12" "TUT13" "TUT17" } \\
\text { "VAP14" "VCM14" "VTS14" }\end{array}$ \\
\hline 2 & $\begin{array}{l}\text { "CBT11" "CBT12" "CBT13" "CBT14" "CBT15" "CBT17" "CBT18" "CKC12" "CKC13" "CKC14" } \\
\text { "CKC15" "CKC17" "CKC18" "CKD08" "CKD09" "CKD10" "CKD11" "CKD12" "CKD13" "CKD14" } \\
\text { "CKD15" "CKD16" "CKD17" "CKD18" "CKTh12" "CKTh13" "CPT14" "CPT15" "CPT17" "CPT18" } \\
\text { "CPS12" "CPS13" "CPS14" "CPS15" "CPS17" "CPS18" "CSR12" "CSR13" "CSR14" "CSR15" } \\
\text { "CSR17" "CSR18" "CST09" "TNK08" "TNK09" "TNK12" "TNK13" "TNK18" "TSK07" "TSK08" } \\
\text { "TSK09" "TSK12" "TSK13" "TSK18" "VAP07" "VAP08" "VAP09" "VAP10" "VAP11" "VAP12" } \\
\text { "VAP13" "VCM07" "VCM08" "VCM09" "VCM10" "VCM11" "VCM12" "VCM13" "VCM17" } \\
\text { "VCM18" "VTS07" "VTS08" "VTS09" "VTS10" "VTS11" "VTS12" "VTS13" "VTS17" "VTS18" }\end{array}$ \\
\hline 3 & $\begin{array}{l}\text { "CKC11" "CKT07" "CKT08" "CKT09" "CKT10" "CKT11" "CKT12" "CKT13" "CKT15" "CKT16" } \\
\text { "CKT17" "CKT18" "CPS11" "CSK07" "CSK08" "CSK09" "CSK10" "CSK11" "CSK12" "CSK13" } \\
\text { "CSK14" "CSK15" "CSK16" "CSK17" "CSK18" "CSP07" "CSP08" "CSP09" "CSP10" "CSP11" } \\
\text { "CSP12" "CSP13" "CSP14" "CSP15" "CSP16" "CSP17" "CSP18" "CSR11" "CSS07" "CSS08" } \\
\text { "CSS09" "CSS10" "CSS11" "CSS12" "CSS13" "CSS14" "CSS15" "CSS16" "CSS17" "CSS18" "CST07" } \\
\text { "CST08" "CST10" "CST11" "CST12" "CST13" "CST14" "CST15" "CST16" "CST17" "CST18" "LVT10" } \\
\text { "LVT13" "TUT18" "VAP17" "VAP18" }\end{array}$ \\
\hline 4 & $\begin{array}{l}\text { "VTV07" "VTV08" "VTV09" "VTV10" "VTV11" "VTV12" "VTV13" "VTV14" "VTV17" "VTV18" } \\
\text { "VVL07" "VVL08" "VVL09" "VVL10" "VVL11" "VVL12" "VVL13" "VVL14" "VVL17" "VVL18" }\end{array}$ \\
\hline
\end{tabular}




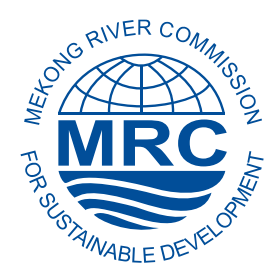

\section{Mekong River Commission Secretariat}

P. O. Box 6101, 184 Fa Ngoum Road, Unit 18 Ban Sithane Neua, Sikhottabong District, Vientiane 01000, Lao PDR

Tel: +85621263 263. Fax: +85621263264

ww.mrcmekong.org

(C) Mekong River Commission 2021 